Slavia Centralis sitevilka 212019 | lemin XII 
Slavia Centralis

(SCN) ISSN 1855-6302

Izdaja

Oddelek za slovanske jezike in književnosti

Filozofska fakulteta Univerze v Mariboru

Published by

Department of Slavic Languages and Literatures

Faculty of Arts, University of Maribor

http://www.ff.um.si/

Glavni in odgovorni urednik - Editor-in-chief

Marko Jesenšek (Univerza v Mariboru - University of Maribor, SLO)

Uredniški odbor - Editorial Board

Silvija Borovnik (Univerza v Mariboru - University of Maribor, SLO; urednica za literarne vede -

literature editor), Ludvik Karničar (Karl-Franzens-Universität Graz - University of Graz, A; urednik za jezikoslovje - linguistics editor), Jožica Čeh Steger (Univerza v Mariboru - University of Maribor, SLO), Alenka Jensterle Doležal (Univerzita Karlova v Praze - Charles University of Prague, CS), Mihaela Koletnik (Univerza v Mariboru - University of Maribor, SLO), Mark Richard Lauersdorf (University of Kentucky, USA - Univerza v Kentuckyju, ZDA), István Lukács (Eötvös Loránd Tudományegyetem - Eötvös Loránd University of Budapest, H), Irena Stramljič Breznik (Univerza v Mariboru - University of Maribor, SLO), Miran Štuhec (Univerza v Mariboru - University of Maribor, SLO), Božena Tokarz (Uniwersytet Śląski - University of Silesia, PL)

Tehnična urednica - Technical editor

Natalija Ulčnik (Univerza v Mariboru - University of Maribor, SLO)

Jezikovni pregled - Language Editors

Natalija Ulčnik (slovenščina - Slovenian)

Mojca Breznik (angleščina - English)

Uredniški svet - Advisory board

$\dagger$ Eric P. Hamp (Chicago), Gerhard Neweklowsky (Klagenfurt), István Nyomárkay (Budapest), Ivo Pospíšil (Brno), Emil Tokarz (Bielsko-Biała)

(C) Slavia Centralis $(\mathrm{SCN})$

SCN izhaja dvakrat na leto. - SCN is published twice yearly.

Vključenost SCN v podatkovne baze - SCN is indexed/abstracted in:

Digitalna knjižnica Slovenije (dLib.si); Directory of Open Access Journals (DOAJ); European Reference Index for the Humanities (ERIH PLUS); KU ScholarWorks; Linguistic Bibliography, The Netherlands; Modern Language Association of America (MLA), Directory of Periodicals, New York; Scopus (Elsvier); Ulrich's Periodicals Directory, R. R. Bowker, NY, USA

Naslov uredništva - Editorial address

Slavia Centralis, Filozofska fakulteta, Koroška cesta 160, SI - 2000 Maribor

Letna naročnina: $12 €$, za študente in dijake $8 €$

TRR: 01100-6000020393

Cena posamezne številke: $6,80 €$

Annual subscription/single issue (outside Slovenia): 24,20 €/13,60€

Tiskano s finančno podporo Agencije za raziskovalno dejavnost Republike Slovenije in Slavističnega društva Maribor. - Published with financial support of Agencija za raziskovalno dejavnost Republike Slovenije and Slavistično društvo Maribor.

Oblikovanje in prelom - Design and typesetting: Grafični atelje Visočnik

Natisnil - Printed by: Tisk Žnidarič, d. o. o.

Naklada-Circulation: 150 


\section{Vsebina / Contents}

\section{Razprave / Studies}

5 Alenka Jensterle Doležal, Pri mojih durih čaka smrt. Osupljiva privlačnost niča. Dekadentne tendence v poeziji Vide Jeraj / Next to my Door the Death is waiting. Longing for Love. Longing for Death. Vida Jeraj - Slovenian decadent Poetess

18 Iryna Borysiuk, Postcolonial identity in Yurii Andrukhovych's poetry: landscapes and dislocation / Postkolonialna identiteta v poeziji Jurija Andruhoviča: pokrajine in dislokacije

33 Dragica HaramiJa, Spodbujanje družinskega branja v otrokovem predšolskem obdobju: Predšolska bralna značka / Encouraging Family Literacy in Child's Pre-school period: the Pre-school Reading Badge

46 PRIMOŽ MLAČNIK, Kulturistike - kulturološka branja beletristike / Culturistix - Culturological Readings of Belles Lettres

58 Miodarka Tepavčević, Konstrukcija ženskog identiteta u poeziji Tina Ujevića / Oblikovanje ženske identitete v poeziji Tina Ujevića / The construction of female identity in the poetry of Tin Ujević

70 JANA Villnow KomÁRKovÁ, Projekt Etymologického slovniku české a slovenské vinohradnické a vinařské terminologie / Projekt Etimološki slovar češke in slovaške vinogradniške ter vinarske terminologije / The project of the Etymological dictionary of the Czech and Slovak viticultural and vinicultural terminology

85 Magdalena SteciąG, "What is the best language for Eastern Europe?" Lingua receptiva as a new approach in Slavic intercommunication research / Kateri jezik je najboljši za vzhodno Evropo? Lingua receptiva kot nov pristop v slovanskih raziskavah medsebojnih komunikacij 
96 ВітАЛІй МАКСимчУк, НеозаПозичення в українському футбольному інтернет-дискурсі / Nove prevzete besede v ukrajinskem nogometnem spletnem diskurzu / New borrowed words in Ukrainian football Internet-discourse

Jubileji / Celebrations

114 Martina OrožEn, Ob sedemdesetletnici dopisnega člana Slovenske akademije znanosti in umetnosti dr. Ludvika Karničarja

\section{In Memoriam}

119 Martina OroŽEn, Zinka Zorko (24. februar 1936-22. marec 2019). Besede slovesa

121 Wolfgang Mieder, Peter Grzybek (November 22, 1957 - May 29, 2019). In Memoriam

\section{Ocene, zapiski, poročila / Reviews, Notes, Reports}

133 SiLva BelšAK, Ivan Cankar v medkulturnem prostoru. Ob stoti obletnici Cankarjeve smrti

138 Natalija UlČNiK, Projekt Slovenščina na dlani

141 Jožica Čen Steger, Simona Pulko, Melita Zemljak JonTES, Razstava o Ivanu Cankarju Romal sem po široki cesti

143 Navodila avtorjem

145 Guidelines for contributors 


\title{
Pri mojih durih čaka smrt. Osupljiva privlačnost niča. Dekadentne tendence v poeziji Vide Jeraj
}

\author{
Alenka Jensterle Doležal \\ Karlova univerza $v$ Češki republiki, Filozofska fakulteta, Jana Palacha 2, \\ Praga 1-CZ 11638 Praga, alenka.dolezalova@ff-cuni.cz
}

\begin{abstract}
1.01 Izvirni znanstveni članek - 1.01 Original Scientific Article
V razpravi ${ }^{1}$ se tematizirajo dekadentne tendence v poeziji in življenju prve slovenske pesnice intime Vide Jeraj (Franice Vovk, 1875-1932). Lirična pesnica je bila vitalni element slovenske moderne tako na Bledu (Zasipu) kot na Dunaju. Začela je pisati v kontekstu sprememb v srednjeevropskih kulturah, ki so se zaključile na koncu prve svetovne vojne $\mathrm{z}$ razpadom skupne države. Pripadala je generaciji kozmopolitskih avtoric, ki se je uveljavila $\mathrm{v}$ obdobju fin-de-siècla $\mathrm{v}$ slovenski kulturi, v tem času na periferiji avstro-ogrskega imperija. V njenem literarnem opusu nas zanimajo pesmi o smrti.
\end{abstract}

The topics of the article are the decadent tendencies in the poetry and life of the first Slovenian female lyricist Vida Jeraj (Franica Vovk, 1875-1932) who was a vital part of the Slovenian modernist network ("Slovenian moderna") in Bled (Zasip) and Vienna. She began to write in the context of transformation in Central European cultures which ended with the collapse of the former joint State. Jeraj belonged to the generation of young cosmopolitan women writers who broke through in in the Fin-de-Siècle period in Slovene society, at that time the periphery of the Austro-Hungarian Empire. In her literary work we analyse poems expressing motives of death.

Ključne besede: poezija Vide Jeraj, dekadenca v slovenski književnosti, slovenska moderna, slovenske avtorice, smrt v poeziji

Key words: poetry by Vida Jeraj, decadence in Slovenian literature, Slovenian "moderna", Slovenian women writers, death in poetry

I.

V članku nas zanimajo dekadentne težnje v življenju in poeziji Vide Jeraj (s pravim imenom Franice Vovk, 1875-1932), ki je kot pesnica smelo začela objavljati v Slovenki že od leta $1896 .^{2}$ Nekaj let se je kot pesnica intimne lirike uspešno

\footnotetext{
${ }^{1}$ Članek je nastal v okviru projekta na Filozofski fakulteti UK v Pragi (Q13 - Mista střetávání: strategické regiony mezi Evropou, severni Afrikou a Asií, koordinator: Berounský).

${ }^{2} \mathrm{~V}$ slovenski javnosti se je pojavila že nekaj let prej s prispevki v Vesni.
} 
uveljavljala v slovenskem prostoru. Svojo edino pesniško zbirko, ki jo je nekaj let skrbno pripravljala, je izdala leta 1908. Zaradi negativne, mizogine recepcije te zbirke in osebnih razlogov (Jensterle Doležal 1917: 70-71) je njen glas po letu 1910 skoraj utihnil, po prvi svetovni vojni je njena ustvarjalna energija ugasnila. ${ }^{3}$ Identifikacija s prvo pesnico Sapfo, ki jo je leta 1922 naredila v zadnji pesmi, napisani za Ljubljanski zvon, ni bila naključna; hotela je postati profesionalna ustvarjalka, kljub neverjetnemu pogumu in vidni nadarjenosti je bila kot pesnica v slovenskem javnem prostoru po prvi svetovni vojni pozabljena, izpoved »lepe duše« je izzvenela v prazno, pesnica se je »žrtvovala neusmiljenim bogovom sredi praznega svetišča (Jeraj 1922: 221).

Prva slovenska izrazito lirična pesnica je bila tudi vitalni del slovenske moderne, najprej v Sloveniji, potem na Dunaju (Jensterle Doležal 2017: 49-56). Na Dunaju je skupaj s svojim možem gojila celo neke vrste literarni salon (Jeraj Hribar 1992: 23). ${ }^{4}$ Najbolj prijateljski stik je imela z Murnom, ki je bil - čeprav mlajši - tako njen literarni učitelj kot prijatelj. Tudi ona je spadala $v$ generacijo kozmopolitskih, nomadskih slovenskih pisateljev, ki so se v konservativni mali družbi na obrobju avstro-ogrskega imperija uveljavili v obdobju fin-de-siècla. V pismu Viki Juvančičevi 4. 9. 1901 je jasno ubesedila novo senzibilnost umetnikov na prelomu stoletja; občutke krize in konca neke epoha; zavedanja disharmonije v svetu in kaosa $\mathrm{v}$ lastni notranjosti je poudarila $\mathrm{z}$ modernim razumevanjem časa:

Harmonije ni nad nami, kakor je nad gozdovi, nad poljanami, nad širnimi pustinjami. V naših dušah ni tiste harmonije! Mi živimo, kakor bi mogli hiteti naglo, naglo, samo da nas preje sreča konec ... In v vseh nas, ki so nas, žalibog, učili misliti, je to nezadovoljstvo, v vsej naši generaciji se izraža - (Jeraj v Boršnik 1935: 283)

Samo nekaj let (od leta 1895 do leta 1901) je - tako kot večina prvih slovenskih avtoric - opravljala delo učiteljice in prav takrat se je $\mathrm{z}$ novo, intimno poezijo poizkusila uveljaviti v slovenskih časopisih. Pri tem ji je pomagala tudi »sestrska povezanost « mladih intelektualk okrog časopisa Slovenka. Prodor ženskih glasov v slovenski literarni prostor je bil - tako kot v ostalih delih monarhije - povezan s feminističnim gibanjem in novimi idejami o mestu žensk v družbi in tudi v umetnosti. Agatha Schwartz je v svoji knjigi o avstro-ogrskih avtoricah poudarila, da je bil glede tega prelom stoletja eden od najbolj kulturno in literarno zanimivih obdobij v zgodovini Srednje Evrope (Schwartz 2008). Pomemben vidik fin-de-sièclovske modernosti je bil obstoj močnega in organiziranega ženskega gibanja, pa tudi nastop nove generacije ženskih avtoric. Pod taktirko dveh urednic, Marice Nadlišek (kasneje Nadlišek Bartol) in Ivanke Anžič Klemenčič, se je oblikoval krog ženskih pesnic: Franje Trojanšek - Zorane (1867-1935), Vide Jeraj (1875-1932), Kristine Šuler (1866-1959), Ljudmile Poljanec (1874-1948), Marice Strnad (1872-1953) in Ljudmile Prunk (1878-1947) (Verginella 2017). Prav one so izoblikovale nov

\footnotetext{
${ }^{3}$ Po poroki s Karlom Jerajem je do leta 1908 živela na Dunaju, potem na obrobju Dunaja, leta 1918 se je z družino vrnila $\mathrm{v}$ domovino.

${ }^{4}$ Glej tudi pisma Mariji Reisner, roj. Ogrinc. Zapuščina Vide Jeraj, Ms. 1213. Rokopisni oddelek v NUK-u v Ljubljani.
} 
tip ženske - kozmopolitsko orientirane intelektualke v slovenskem prostoru ${ }^{5} \mathrm{z}$ drugačnim odnosom do sebe, drugega in do svojega telesa, s kozmopolitskim pristopom tudi v svojem ustvarjanju (Žerjal Pavlin v Verginella 2017: 53-65). Najbolj izbrušena pesnica med njimi je bila Vida Jeraj, nomadska osebnost z dvojezično, hibridno identiteto, ki se je šolala in umetniško dozorela med Ljubljano, Dunajem in Trstom, med centrom dogajanja in periferijo (glej tudi Jensterle Doležal 2017a: 31-107, 2017b: 47-58, 2018: 21-33).

II.

Marja Boršnik je njeno izbrano delo uredila nekaj let po njeni smrti leta 1935. $\mathrm{V}$ uvodu je filozofska nihanja in psihološka protislovja $\mathrm{v}$ osebnem profilu prve slovenske prave lirične pesnice Vide Jeraj ${ }^{6}$ opredelila kot dekadentna:

Vse, kar je nepričakovanega, novega, lepega, jo zmore le v prvem hipu do dna pretresti, razburiti, navdušiti, kasneje gre mimo vsega hladna, zdolgočasena. Opore, ki bi za trajno ustavila njena nihanja, ki bi enotno usmerila njeno razcepljeno, uničujočo se življenjsko moč, ne najde nikjer. Vse te osnovne poteze njene narave so tako tipično dekadentske, da bi jih bilo težko najti v tolikšni meri še pri kakem slovenskem zastopniku te dobe ... Ob njih bo Vida obsojena na neprestano iskanje in tavanje brez cilja. (Boršnik 1935: 22)

Tudi v našem članku se osredinjamo na dekadentne tendence v njenem življenju in v poeziji. Erwin Koppen je dekadenco definiral kot dopolnilni izraz za tendence v okviru literature 19. stoletja in fin-de siècla, s katerim se označujejo avtorji, ki so s svojimi spoznanji, ideali in nenavadnimi, celo morbidnimi podobami, prizadeli tedanjo meščansko družbo, saj so pod vprašaj postavili njen meščanski sistem in življenske navade (glej Koppen 1973). Tudi pri slovenskih modernistih se lahko dekadenca izrazi kot upornost $\mathrm{v}$ njihovem obnašanju in $\mathrm{v}$ določenih trenutkih življenjska drža. Pesnikova posebna občutljivost je bila povezana z občutki naveličanosti, depresije, izgube, tesnobe in zavedanja krize stoletja ter konca neke epohe. To lahko raziskujemo tudi v primeru Vide Jeraj.

Dekadentna stališča, povezana z uporniškim načinom obnašanja, lahko najdemo samo v času njenega prizadevanja po samostojnem življenju v Zasipu (1896-1901). Že takrat se je družila s slovenskimi intelektualci tistega časa - predvsem s predstavniki moderne, ki so radi prihajali k njej na Bled. Njeno nekonvencionalno, za tedanjo družbo šokantno obnašanje, potrjujejo izjave $\mathrm{v}$ njeni korespondenci in $\mathrm{v}$ pismih drugih. Mlado, samozavestno dekle $\mathrm{z}$ »dunajskim načinom razmišljanja«, avstrijsko vzgojo ${ }^{7}$ ter s bohemskim obnašanjem je moralo vznemirjati malo vaško okolje, čeprav v bližini mondenega Bleda. Mlada pesnica je provocirala vaško okolico na provincialnem Zasipu s svojo nenavadno pojavo, s provokativnim

\footnotetext{
${ }^{5}$ Termin »nova ženska« za tip emacipirane intelektualke na prelomu 19. in 20. stoletja se je uveljavil v angleškem in nemškem prostoru (glej Ledger 1997).

${ }^{6}$ Njena poezija je bila zelo malo raziskana, tudi njo so slovenski literarni zgodovinarji opredelili samo kot pesnico narave (Jensterle Doležal 2017: 75-77).

${ }^{7} \mathrm{Na}$ Dunaju je živela in se šolala od leta 1887 do 1891.
} 
obnašanjem $^{8}$ in celo z »izzivajočim« stilom oblačenja. Avgusta Šantel je 31. 5. 1901 pisala mlajši sestri Henriki Šantel - bodoči slikarki, o njeni nenavadni pojavi:

$\mathrm{Na}$ Bledu sem videla neko učiteljico, padla mi je v oči, ker je bila 1. grozno šminkana in pod očmi barvana in 2. oblečena 'secession' jako čudno. Kasneje sem izvedela, da je to tista, ki pod imenom 'Vida' za Slovenko piše ... Tebe bi bila morda zanimala, kajne?' (Greif 2014: 185)

Semantika njenega psevdonima nam kaže, da se je Vida Jeraj istovetila z zgodbo o Lepi Vidi. Tudi tu lahko razmišljamo o skupni duhovni naravnanosti ene generacije: Ivan Cankar je Lepo Vido preinterpretiral v svoji drami, njen lik ga je zasledoval vse od Cukrarne dalje. Vido Jeraj je lahko imponiral prav metafizični presežek hrepenenja ali manko v eksistencialni naravnanosti, ki se kaže v tej ljudski baladi in s katerim se je lahko v teku svojih dni tudi vedno bolj identificirala. Hrepenenje po novem življenju se lepi Vidi v ljudski baladi ne izpolni, njene velike žrtve so nesmiselne in so tragične narave, na koncu jo čaka usodno razočaranje. To je bila tudi usoda Vide Jeraj, ki je začela z velikim upanjem in z željo pisati poezijo: na koncu pa je namesto lepe Vide izpostavila lik Sapfe kot pesnice, ki ni uspela niti v osebnem življenju niti na svoji umetniški poti (Jeraj 1922: 222).

Čeprav se je kar nekaj let poizkusila uveljaviti kot samostojna pesnica $\mathrm{v}$ slovenskem prostoru, je bila - tudi zaradi šibke tradicije avtoric, njena avtorska samozavest zelo negotova. V kontekstu lepovidovskega razočaranja in »poraza sanj« - neuspelega poskusa uveljaviti se kot samostojna, svobodna intelektualka in prodreti $\mathrm{v}$ slovenski javni prostor, moramo omeniti njeno krizo na prelomu leta 1900/1901, ki na osebnem nivoju in v perspektivi spola izraža nasprotujoče tendence in dostikrat brezuspešna prizadevanja po svobodi, s katerimi so se soočale slovenske intelektualke na prelomu 19. in 20. stoletja. Osebna kriza kot po naključju sovpada s splošno krizo na prelomu stoletja. Poroka s Karlom Jerajem, v katero je privolila, je bila dogovorjena tudi pod pritiskom družine. Ne samo da je Jerajeva po nekaj mesecih razdrla zaroko, iz obupanih pisem, ki jih je pisala tako Viki Juvančič kot Franji Trojanšek - Zorani na koncu januarja 1901, izvemo tudi, da se je soočala z veliko krizo in da je hotela pobegniti iz omejujočega stanja:

In zdaj mi je kakor begunu, ki se je ravnokar osvobodil jetniških črnih zidov in neznosnih okovov ...

Kam.

Cilja ne vem, a vse moje bitje vriska polno odrešenja:

V svobodo!

Moji duši je treba prostora, veliko - neskončno! Naprej - v noč, kamorkoli!

(Jerajeva Juvančičevi 23. 1. 1901, glej Boršnik 1935: 31)

${ }^{8}$ Miti o njenem nekonvencionalnem obnašanju v Zasipu in na Bledu so živeli še po njeni smrti. Marja Boršnik je leta 1935 o njeni nenavadni pojavi na Bledu, ki je izstopala v druženju z modernisti, zapisala: »Zgodi se, da v hipni navdušenosti zabije z družbo, ki ji je všeč, v enem popoldnevu vso svojo mesečno plačo. Kaj ji je mar, da bo stradala ves mesec; v skrajni razigranosti zažene čevelj v zrak; tudi brez njega je lahko. Pijana je sama sebe! Sredi ceste igra 'na kampel' s cigaretnim papirjem in udarja z nogo - kavalirji plešejo okrog nje. Dosegla je svoj cilj - dominira! Svojevrsten je način, kako jo časté: namesto preprog ji pogrinjajo pred noge svoje bedne površnike, da stopa po njih kot vladarica. Vida je blažena sredi tega lahkomiselnega, samo trenutku posvečenega bohemstva« (Boršnik 1935: 22).

${ }^{9}$ Henrika Šantel je kasneje Vido Jeraj tudi portretirala. 


\section{1. 1901 piše nekaj podobnega Franji Trojanšek - Zorani:}

Zadnje dni sem prestala hudo duševno krizo; zdaj mi je odrešeno, in moje življenje je dobilo v enem samem silnem hipu novo smer. Tako me je hotel bog od nekdaj. Otresla sem se vseh obzirov, zajedno vseh laži in vsega hinavstva. To se pravi, zdaj sem jaz in svobodna. /.../ Poleti so me zaročili, da se julija omožim ... Jaz pa nameravam v počitnicah na Rusko. Moji duši je treba prostora - brez mej, da si oddahnem! $!^{10}$

Jerajeva je hotela pobegniti pred vsiljeno poroko, kar je izrazila z metaforo potovanja v Rusijo kot v imaginarno deželo svobode. ${ }^{11}$ Nikoli ni odšla v Rusijo in nikoli ne postala profesionalna pisateljica ter se nikoli ni več kot samostojna ustvarjalka uveljavila v slovenskem prostoru. Po krizi se je 3. 9. 1901 poročila z glasbenikom Jerajem, sprejela patriarhalno vlogo žene, odšla z njim na Dunaj in mu tam rodila štiri otroke. Svojo željo po umetnosti in pisanju je kompenzirala z druženjem s pisatelji, slikarji, glasbeniki, ki so prihajali v njen neformalni literarni salon na Dunaju. Iz njenih pisem in avtobiografskih izpovednih pesmi pa odkrijemo, da je bilo njeno čustveno in intelektualno življenje še vedno burno in polno protislovij ter tudi novoromantičnih napetosti. ${ }^{12}$

III.

Podobno kot lahko razmišljamo o njeni dekadentni pojavi z vsemi mukami, ki so spremljale iskanje nove identitete v t. i. samostojnem obdobju pred preselitvijo na Dunaj, lahko tudi zastavimo vprašanje o dekadentnih tendencah v njeni poeziji. Zanimala nas bo dekadenca kot literarnoestetski fenomen v njeni poeziji. V slovenski izpovedni liriki moderne je bila na splošno vidna stilizacija lirskega subjekta v posebne položaje. Osredinili se bomo na dekadentne motive, v poeziji Vide Jeraj so to »privlačne podobe smrti«.

Male literarne družbe $\mathrm{v}$ srednjeevropskem prostoru so bile v tem obdobju odprte za dekadentna gibanja, dekadentne avtorje najdemo med predstavniki Jung-Wien. Večjezični dunajski avtorji so prejemali različne romanske, nemške, slovanske in madžarske vplive, tako je že njihov glavni predstavnik Hermann Bahr v tisku propagiral tujejezično dekadentno literaturo in impresionistično literaturo občutij (Lorenz 2002: 60-62). Dagmar Lorenz poudarja, da je dunajska moderna - posebno pa Hofmannsthal - evropsko dekadenco sprejemala kritično (na primer vprašanje primata umetnosti nad naravo, kot ga je zastavil Charles Baudelaire s fenomenom umetnih svetov - »paradis artificiels« (Lorenz 2002: 64-65). Najbolj razvejeno dekadentno gibanje v srednjeevropskem prostoru najdemo na Češkem in Poljskem. Češka dekadenta Karel Hlaváček in Jiř́ Karásek iz Lvovic sta pisala dekadentne verze pod vplivom Baudelaira in Verlaina in sta bila celo urednika edine

${ }^{10}$ Pisma Vide Jeraj Franji Trojanšek - Zorani. Zapuščina Vide Jeraj, Ms. 1213, Rokopisni oddelek v NUK-u v Ljubljani.

${ }^{11}$ Ruska kultura je imela $\mathrm{v}$ mladi generaciji moderne vse od Zadruge dalje poseben pomen. Jerajevi jo je priporočal tudi učitelj Aškerc. Mlade ustvarjalke iz Slovenke so si dopisovale $\mathrm{v}$ cirilici in s tem simbolno ustvarjale svet povezanosti in skupnih prizadevanj.

12 O njenem življenju in delu glej tudi Škerjanc Kosterca 1959, Hlebanja 2003, Štaus 2011. 
uspešne in najbolj prominentne modernistične dekadentne revije Moderní revue. Hrvaški dekadentni pesnik Vladimir Jelovšek je uspešno širil ideje Stanisława Przybyszewskega na Hrvaškem. Na Poljskem je Kazimierz Przerwa - Tetmajer izdal znano pesniško delo Koniec wieku XIX. in Stanisław Przybyszewski je pisal o dialogu s hudičem in zlom v prozi in drami tako $\mathrm{v}$ poljščini kot nemščini.

Slovenska moderna se je v srednjeevropskem prostoru uveljavila razmeroma pozno: leta 1899 z obema pesniškima antologijama, Cankarjevo Erotiko in Župančičevo Čašo opojnosti, napisanima v dekadentnem tonu in dekorativnem secesijskem stilu. V izpovednih verzih so se lirski subjekti nahajali v atmosferi noči, glasbe in plesa. Nenavadna občutja ljubezni so spremljale tipične fin-de-sièclovske reprezentacije ženske in njenega telesa, rože zla so bile tudi rože mistične, idealne ljubezni (Jensterle Doležal 2009: 149-160). Pesniki so v okviru intimne lirike začeli pogumno pisati o erotiki, telesnosti in razreševali vprašanje spola in odnosa do drugega (ženske). Pesniški izraz se je pri pesnikih gibal tudi v dekadentnih položajih, posebno reprezentacija ženske in ljubezni ni bila samo spiritualno idealna, ampak tudi dekadentno telesna. V glavnem časopisu Ljubljanski zvon so v istem času objavljali prevode pesmi Charlesa Baudelaira in Paula Verlaina (ki so jih nekateri med njimi brali tudi v originalu). V Zvonu so tudi predočili nekatere pesmi iz simbolistične in dekadentne češke lirike kot tudi prosti prevod članka vodilnega češkega teoretika Františka K. Krejčíja, v katerem je interpretiral dekadenco (Jensterle Doležal 2014: 59-64). V majhni slovenski družbi je bila dekadenca že od začetka sprejeta negativno in s številnimi predsodki, tako da so celo avtorji z dekadentnimi tendencami sami odklanjali označitev svojih del s tem terminom.

IV.

Že v drugi številki Slovenke leta 1897 je Vida Jeraj izdala pesem Slutnja, s katero je začela poetiko notranjih občutij, individualizma in spremenjene senzibilnosti, proč od patriotskih izjav in slovanske deklarativnosti. V Slovenki je objavila največ pesmi (41). V svojem opusu je nihala med impresionističnimi opisi narave in pokrajine ter zapisom ljubezenske izkušnje. V upodobitvi ljubezni je zakodirala znano elipso ljubezenskega doživljanja: od prvih ekstaz in začetnih srečanj do trenutkov ločitve in obupa. V impresionističnih zapisih subjekt in objekt rezonirata $\mathrm{V}$ čutnem in dostikrat celo glasbenem doživetju trenutka. V zapis trenutkov pesnica vpleta lastna čustva in celo refleksivno-filozofske utrinke ter religiozne izpovedi. Podobno kot pri ostalih predstavnikih moderne lahko tudi v njenem doživljanju ugotovimo svojevrsten razkol v notranjosti, razpetost in negotovost subjekta, subjekt trgajo notranje napetosti in fragmentarno doživljanje sveta, kar že kaže tudi na »krizo identitete«, ki jo ugotavlja Jacques Le Rider za dunajsko moderno (Le Rider 1997). Njen lirski subjekt izgublja gotovost v percepciji sebe in dojemanju sveta. Eksistenca lirskega subjekta travmatizira iskanje identitete, s tem da poizkuša razumevati kompleksnost in fragmentarnost modernega, kaotičnega sveta. C̆asovna veriga v dojemanju subjekta je pretrgana, pomembni so odtenki, fragmenti in nianse $\mathrm{v}$ zaznavanju pokrajine. Lirski subjekt $\mathrm{v}$ njeni poeziji - podobno kot $\mathrm{v}$ Murnovi - izraža tudi izrazito protislovne občutke. V njeni formi, ki ostaja v okviru tradicionalnega modela kratke pesmi z jasnim ritmom, slutimo sramežljive poskuse 
modernosti. Razpetost med modernim izrazom in ujetostjo v kanon ljudske pesmi se kaže tudi v razporeditvi njene edine pesniške zbirke, ki jo je leta 1908 uredila sama: polovica verzov je napisana v slogu psevdo ljudske pesmi.

\section{V.}

Dekadentno obarvani motivi se pojavljajo v njenih zrelih pesmih, avtobiografskih izpovedih že dekadentno razumljene ljubezni in smrti. V svojih formalno klasičnih pesmih Jerajeva izraža cel spekter modernih občutij: od ekstatičnega doživetja trenutka in drugega do zapisa stanj »bolne, utrujene duše« kot izraza dekadentne duševnosti. V izpovedih se pojavljajo občutki naveličanosti, izgube smisla in spleena, ${ }^{13} \mathrm{v}$ pesmih se tke atmosfera melanholije in žalosti.

Svojo najdaljšo pesem, Mrtvemu pesniku Aleksandrovu I, II, sestavljeno iz dveh delov, je napisala ob smrti pesnika in prijatelja Murna (prvič izdano v LZ leta 1901). Izgubo pesniškega genija tematizira $\mathrm{v}$ treh časovnih ravneh: v prvi kitici opisuje jutro v naravi po pesnikovi smrti, čas v naslednjih kiticah premakne v čas umiranja ( $\mathrm{v}$ treh kiticah se osredini na konkretni obisk pesnice pri umirajočem pesniku). V filozofski naravnanosti dominira kategorija narave, ki pomeni glavno vrednostno kategorijo tako za pesnika kot tudi za avtorico. V njej lastni lirični strategiji organizira metafore v opoziciji časa in prostora. Podobi smrti pesnika zoperstavlja - podobno kot v Jenkovih Obrazih - brezdušno, spomladansko naravo, ki kipi od »mirnega ravnodušja« in ji ni mar za smrt pesnika.

Tudi v drugem, splošnem delu Murna označi kot pesnika narave, ki je iz revščine »zamaknil v sinji se azur« (Jeraj 1935: 85). V pesmi avtorica upodablja mit pesnika genija s tem, da poudarja vero $\mathrm{v}$ njegovo nesmrtnost. Pesnica mitizira njegovo osebnost kot eno izmed glavnih v svoji generaciji. ${ }^{14} \mathrm{~V}$ pesniškem nekrologu upodablja zelo konkretne slike umiranja in smrti pesnika, ki že izražajo privlačnost smrti. Predstavniki slovenske moderne so bili v pesniških predstavah in filozofskih idejah dediči romantike, v razumevanju človeka so izhajali iz razbolelosti eksistence. Smrt je bila tudi pri romantikih pomembna kategorija (na primer v Prešernovi poeziji). V moderni se smrt spreminja $\mathrm{v}$ enega od glavnih pojmov in modernisti jo doživljajo kot vrednostno pozitiven fenomen (na primer Cankar v svoji literaturi).

Doživljanje subjekta se izostri v izpoved mrzle, cinične resignacije v poznih ljubezenskih pesmih (Tam zunaj, tam daleč je moja mladost, Pojdi v sever), napisanih okrog leta 1908. Prav v strogo zgoščeni pesmi Pri mojih durih čaka smrt (tudi iz leta 1908) pesnica tematizira bližino smrti. Izguba ljubljenega bitja pri lirskem subjektu stopnjuje hrepenenje po smrti in to pesnica izrazi s skopimi besednimi sredstvi in v minimalizirani obliki. Verzi sugerirajo gotsko imaginacijo: lirski subjekt čaka na smrt, saj bo prav ona na pokopališču odprla vrata, zaklenjena s tremi ključavnicami. Iz opisnega konstatiranja v prvi kitici lirski subjekt v drugi kitici preide v nagovor smrti, ki jo vabi v zaupno bližino:

${ }^{13}$ Doživetja spleena je prvi opisal Charles Baudelaire v svojih verzih.

${ }^{14}$ Prepričanje o nesmrtnosti pesniškega genija je zakoličil že Prešeren v svoji poeziji (predvsem $\mathrm{v}$ pesmi Neiztrohnjeno srce). S tematizacijo pesnikove nesmrtnosti je v moderni nadaljeval Oton Župančič v znanem ciklu Manom Josipa Murna - Aleksandrova. 
Pri mojih durih čaka smrt / in govori: jaz orjem vrt, / kjer duše se vtolažijo, / kjer beli kamni stražijo.

- Ključavnice železne tri, zapaha tri mi, smrt, odpri! - / Ves dan tako čakala je / vso noč potrkovala je ... (Jeraj 1935: 120)

Najbolj značilne za naše razmišljanje o dekadentnih težnjah v njeni poeziji so njene osebne pesmi o smrti in samomoru (glej tudi Jensterle Doležal 2017: 99-100). Hrepenenje po novem življenju se prav $\mathrm{v}$ tovrstnih pesmih zelo hitro sprevrže $\mathrm{v}$ hrepenenje po smrti. V svojem pesniškem razvoju je Jerajeva napisala kar nekaj pesmi z motivom samomora in smrti v vodi. ${ }^{15}$ To je bil motiv, ki se ji je vračal v različnih fazah umetniškega ustvarjanja, celo tik pred smrtjo. Vse niso bile uvrščene $\mathrm{v}$ pesniško zbirko in $\mathrm{v}$ njeno zbrano delo.

V pesmi Balada I (LZ 1904) jezero priteguje izgubljeno dušo v globino. Balada je napisana $\mathrm{v}$ duhu ljudske imaginacije: duša po začetni negotovosti konča v globinah vode. Prva kitica spominja na baročno razporeditev oseb v prostoru: zapuščena duša je prišla $\mathrm{k}$ jezeru govorit $\mathrm{z}$ bogom. Situacija smrti v vodi se v drugem delu groteskno ponazori z nežno uspavanko, ki jo jezero poje izgubljeni duši pred smrtjo. Stilizirana uspavanka, ki jo poje ljubeča mati svojemu otroku, tragični ton izpovedi še zaostri:

Jezero je vzelo / zvezde v naročaj, / pelo in zibalo: / aja, aj, aj, aj - // Kaj si izgubilo, / dete moje, tod, / da te v noč privela / je samotna pot? // ... Jezero je vzelo / dušo v naročaj, pelo in zibalo / aja, aj, aj, aj - (Jeraj 135: 101, 102)

V pesmi Jezero mojih dni (rokopis 1914) ${ }^{16}$ je v drugi kitici spet upodobljeno mrtvo telo $\mathrm{v}$ vodi, glavna podoba je utopljenec na dnu jezera. $Z$ njegovo smrtjo se lirski subjekt čuti mistično povezan: svet mrtvih ga privlači, saj je prostor odrešenja. Od tod tudi genitivni izraz v sintagmi - naslovu pesmi: konkretno jezero je sinonim za notranje jedro jaza: zato jezero mojih dni. Je tudi prostor smrti, tako da je povezava med subjektovo naravnanostjo in zunanjim prostorom uničujoča in destruktivna, hkrati pa zaželena.

Pesem ima tri štiriverzne kitice, ki v minimalizirani obliki podajajo osnovno spoznanje pesmi. Glavna podoba je stanje po izvršenem dogodku: po samomoru, ki se je že zgodil. V prvi kitici lirski subjekt začenja z vprašanjem, ki lahko sugerira prav globino in že temačno nerazumljivost jaza: jaz je jezero brez dna. $\mathrm{V}$ izpovedi nadaljuje z odgovorom: svet slutenj in spominov jo straši, groza človekove eksistence jo zasleduje, med realnostjo in sanjami se že modernistično postavlja enačaj: »Slutnje, spomina val / straši me kot v snu« (Jeraj 1935: 130).

${ }^{15}$ Misel na samomor jo je spremljala tudi v realnem življenju. Tudi sama je v mladosti poizkusila narediti samomor z vžigalicami. 29. 11. 1892 se je ustrelil njen prijatelj in bratranec Tone Svetina, s katerim je imela romantično razmerje. Prav pesem Spomin ob Savi (LZ 1897) upodablja realni dogodek, saj se v izpovedi spominja na ljubezen in tudi na smrt ljubega prijatelja, s katerim sta se srečevala ob Savi v kotičku, ki sta ga poimenovala Ljubodol. Fant se je v navalu čustev ustrelil prav na bregovih Save ... Pesnica zariše svoj brezup po smrti prijatelja z metaforo čolna, ki je izgubil svojo orientacijo na oceanu.

${ }^{16}$ Vida Jeraj Ivanu Cankarju v nedatiranem pismu z letnico 1914. 
Pesem ima strog pomenski lok: v drugi kitici nam zariše konkretno podobo, ki deluje s kontrastno dramatično razporeditvijo: na eni strani grozljiva predstava mrtvega na črnem dnu, na drugi opojnost in neomejenost prostora, ki ga še poudarijo odbleski svetlobe sonca in zvezd na površini jezera.

Tudi tukaj avtorica $\mathrm{v}$ poetoloških strategijah operira s prostorskimi opozicijami in kontrastnimi podobami v semantični kompoziciji, ki naznačujejo metafizično strukturo pesmi: na eni strani motiv mrtvega na črnem dnu, na drugi barvna narava pokrajine, ki se razširja v neskončen kozmos.

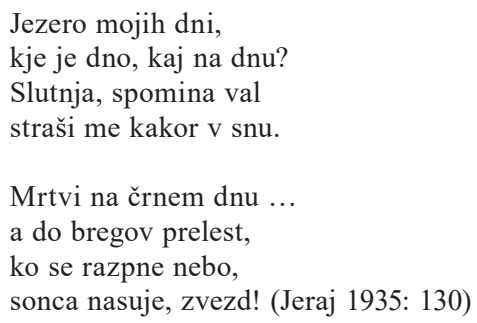

Prav tu bi lahko govorili o reprezentaciji lepe smrti, ki je predstavljena v harmoniji z vesoljem. Vsiljuje se primerjava pesmi s Cankarjevim tekstom Milan in Milena, ${ }^{17}$ ki se konča podobno tudi s predstavo tragičnega konca moškega in ženske, ki sta $\mathrm{v}$ smrti končno $\mathrm{v}$ harmoniji s svetom in neskončnostjo prostora.

Zadnja kitica je lirični decrescendo in umiritev dramatičnih nasprotij, pa tudi priznanje poraza lirskega subjekta: v tipični impresionistični pesmi, ki se gradi na vtisih, zunanji prostor narave zbudi čisto določeno psihično stanje v notranjosti subjekta. V impresiji ob sprehodu ob jezeru izstopa motiv dveh, treh brez, ki poudari prav osamljenost subjekta. Preteklost je premočna in se povezuje z žalostjo: osnovno, prevladujoče občutje lirskega subjekta je žalost.

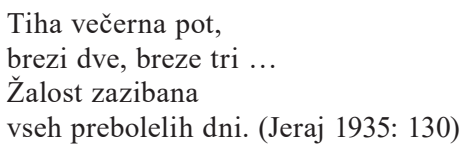

Glede na to, da pesem poznamo kot rokopis v pismu, ki ga je Jerajeva poslala Cankarju leta 1914, lahko to pesem z zelo podobno podobo, ki korespondira s koncem Milana in Milene, ${ }^{18}$ razumemo kot posvetilo skupnemu dojemanju in duhovnemu prijateljstvu med njima in kot pozitivno resonanco na Cankarjev tekst, ki ji je bil očitno všeč. ${ }^{19}$

\footnotetext{
${ }^{17}$ Tekst je Ivan Cankar objavil v Ljubljanskem zvonu leta 1913.

${ }^{18}$ Milan in Milena na koncu ljubezenske pravljice naredita samomor: vsak na enem koncu jezera.

${ }^{19}$ Motiv lepe smrti je Ivan Cankar nakazal že v pesmi Na zemljo dahnil je večer (v ciklu Helena v Erotiki), kjer se v sanjski realnosti pesniku prikaže ljubica na mrtvaškem odru, obdana z ljudmi, ki molijo. Leta 1906 je hrvaški pesnik Antun Gustav Matoš ubesedil podobni motiv v pesmi Utjeha kose (Uteha las). Lirski subjekt v sanjski realnosti nagovarja mrtvo ljubico, ki leži na mrtvaškem odru v »dvorani, napolnjeni s krasno smrtjo« (Matošev izraz) - na prelepem truplu dekleta so »živi« samo razkošni lasje.
} 
Motiv samomora upodobi tudi v pesmi Konec, objavljeni leta 1924 v LZ. V kratkih minimaliziranih verzih označuje smrtnost in trenutnost človekovega življenja kot najgloblje spoznanje. Tudi tu spoznanje podkrepi s kontrastom in grotesknim hiatom v sliki. Že v prvi kitici podobo človeka, ki gre v sinje spomladansko jutro, dekorativno-secesijsko obarvano s cvetjem trobentic, prekine z napovedjo smrti in motiva samomora s pištolo, ki zmaguje nad podobami življenja. Smrt je naslikana $\mathrm{v}$ cvetličnim okrasju trobentic kot podoba lepe smrti med rumeno in modro barvo pomladi.

Gre ti človek v sinje jutro, ... / (cvetje primul čez in čez) / da odreši ga življenja / in pomladi - samokres. (Jeraj 1935: 127)

Narava ni več samostojna sila, deluje samo v kontrastu z upodobljeno situacijo samomora. Groteskni hiat na koncu sugerira smrt kot rešitev. V drugi kitici sledi retorično vprašanje, ali je to dejanje smisla ali nesmisla: dejanje bedaka ali modrijana (Jeraj 1935: 127).

V zadnji pesmi Pod bregom pesnica tematizira samomor najboljšega prijatelja v preteklosti in njegove posledice za lastno občutje. Pesem z motivom samomora in konca pričakovanj pod bregom reke Save je bila leta 1832 objavljena v Ženskem svetu šele po njeni smrti in ni bila uvrščena v izbor. Začetno avtobiografsko izpoved razvije na koncu ustvarjanja: tekst je epsko nadaljevanje starega zapisa (Spomin ob Savi, Jeraj 1897: 38) ${ }^{20}$ v veliko daljši obliki. V osebni, sentimentalni izpovedi pesnica sledi strogo formalnim zahtevam metra in rime in ne odstopa od realističnega zapisa. Glede na prejšnje pesmi pogrešamo višino liričnega zanosa, poezijo nedoločne sugestije in metaforično raven zapisa. V izpovedi, za razliko od prvega zapisa, poudari osebo drugega in $\mathrm{v}$ opisu spet izhaja iz konkretnega prostora. $\mathrm{V}$ prepletu opisa preteklosti in notranjega stanja lirske sedanjosti se večkrat ponovita občutji obupa in resignacije, pesnica se vrača k sebi in že nakazuje edino rešitev iz neznosnega bivanja v samomor:

Kako iztrgati neizmerno bol,

Kako rešiti vsega se gorja?

Pokazal sam mi pot je v Ljubodol -,

Pod 'bregom' - Save bistre val igra! ... (Jeraj 1932: 201)

Usihanje pesniške inspiracije, ki jo duši osebna bolečina, izraža dejstvo, da je pesem močno pod vplivom Prešernove dikcije iz pesmi Kam: v prvi kitici (zadnja kitica je ponovitev prve) slišimo vprašanja, ki jih je zastavil njen sorodnik skoraj sto let pred tem.

${ }^{20}$ Pesem je lirska izpoved pesnice ob smrti sorodnika: v prvi kitici označi dogodek, v drugi nakaže opustošenje v lastni notranjosti s primero čolna, ki se je izgubil na morju, v tretji občutje žalosti poveže s konkretnim prostorom. Na koncu konkretni opis realnosti zamegli z motivom sanj: »In plakam, plakam v žalnem snu / Ob strugi šumne Save» (Jeraj 1897: 38). 
Hrepenenje po smrti je bilo tudi v njenem življenju premočno. ${ }^{21} \mathrm{Na}$ koncu se v njeni zgodbi realnost in fikcija tragično povežeta: na štiriindvajseto obletnico smrti svojega sina je 1. maja 1932 Vida Jeraj naredila samomor.

VI.

Vida Jeraj je z intimno poezijo prinesla bistven premik v slovenski poeziji: šele danes njeno izbrušeno poezijo premišljeno kratkih verzov lahko odkrivamo kot nov glas v slovenski moderni. Njeno delo se upravičeno uvršča med dosežke srednjeevropskih modern. Pri analizi njenega dela tako ugotavljamo, da to ni bila samo intimna slikarka narave in notranjih občutij, ljubezenskih trenutkov zanosa in opoja in tudi izgube, ampak tudi zelo modernih občutij in protislovnih tendenc - in da je bila tudi pesnica smrti. ${ }^{22}$ Niso ji bili tuji tudi dekadentni razponi in tendence, ki izražajo tipična fin-de-sièclovska občutja, pogosto tematizirana $\mathrm{z}$ motivi smrti in samomora, podoba smrti se $\mathrm{v}$ njeni poeziji estetizira in poveže $\mathrm{z}$ motivi narave in pojmom prostora. Prav te je refleksija njene poezije v slovenski literarni vedi spregledala tudi zaradi omejene recepcije njenega dela v slovenskem kulturnem prostoru.

\section{LITERATURA}

Marja BORŠNIK, 1932: Obrazi in duše. Vida Jerajeva. Ženski svet X/7-8, 9, 10, 193-201, 245-250, 277-283.

--, 1935: Uvod. Izbrano delo, Vida Jerajeva. Ur. Marja Boršnik. Ljubljana: Ženska založba Belo-modre knjižnice. 7-65.

- -, 1962: Študije in fragmenti. Maribor: Založba Obzorja Maribor. 79-115.

Tatjana GRIEF, 2014: Slikarka v senci: Vrzeli v zgodovinjenju ženske umetnice. Časopis za kritiko znanosti, domišljijo in novo antropologijo 42/256, 132-156.

Alenka JENSTERLE DOLEŽAL, 2009: Myths about Women in the Slovene »Moderna«: Mother or a Whore. Slovene Studies, Journal of the Society for Slovene Studies 30/2, 149-160.

- -, 2014: Avtor, tekst, kontekst, komunikacija. Poglavja iz slovenske moderne. Maribor: Mednarodna založba Zora Filozofske fakultete. (Mednarodna knjižna zbirka Zora, 103).

- -, 2017a: Med impresijo in dekadentnimi občutki - Poezija Vide Jeraj. Ključi od labirinta. O slovenski poeziji. Maribor: Mednarodna založba Zora Filozofske fakultete Univerze v Mariboru. (Mednarodna knjižna zbirka Zora, 122). 31-107.

Alenka JENSTERLE DOLEŽALOVÁ, 2017b: Aporie slovinské moderny: poetika slovinské básnířky Vidy Jeraj. Klíčové problémy současné slavistiky. Ur. Ivo Pospíšil, Miloš Zelenka a Lenka Paučová. Brno: Česká asociace slavistů. 47-58.

${ }^{21}$ Spoznanje o tem, da pripada že bolj drugi strani smrti, je dozorelo v njej že prej. 31. 9. 1931 je napisala Zorani, najboljši prijateljici in sorodnici, tudi pesnici: »Kako ti je? Jaz sem samo še stroj, ne več duševnost. Oči upiram samo v kraj počitka in miru - četudi ljubim to lepo zemljo čez vse!« (Pisma Vide Jerajeve Franji Trojanšek - Zorani. Zapuščina Vide Jeraj. Ms. 1213, Rokopisni oddelek v NUK-u v Ljubljani).

${ }^{22}$ Tema smrti pri slovenskih pesnikih tega časa ni bila glavna, samo pri prozaiku in dramatiku Ivanu Cankarju je bila v nekaterih delih ontološka tema. 
- -, 2018: Imagining the not Imaginable. Slovenian Women Poetry in the Fin-de-Siècle Period and the Beginning of the 20th Century. Česká slavistika. Ur. I. Pospíšil, M. Zelenka, L. Paučová. Brno: Česká asociace slavistů. 21-33.

Ana HLEBANJA, 2003: Pesnica Vida Jeraj. Diplomsko delo. Ljubljana: Filozofska fakulteta. Vida JERAJ, 1897: Spomin ob Savi. Ljubljanski Zvon 17/2, 88.

--, 1908: Pesmi. Schwentner.

- -, 1922: Sappho. Ljubljanski zvon 42/4, 220-221.

- -, 1932: Pod »bregom«. Ženski svet 10/7-8, 201.

--, 1935: Izbrano delo. Ur. Marja Boršnik. Ljubljana: Ženska založba Belo-modre knjižnice.

Vida JERAJ HRIBAR, 1992: Večerna sonata. Spomini z Dunaja, Pariza in Ljubljane 1902-1933. Zapisal Marjan Kovačevič, uredil Marko Uršič. Ljubljana: Mladinska knjiga.

Erwin KOPPEN, 1973: Dekadenter Wagnerismus. Studien zur europäischen Literatur des fin de siècle. Berlin, New York: de Gruyter.

Sally LEDGER, 1997: The New Woman. Fiction and Feminism at the Fin-de-siècle. Manchester, New York: Manchester University Press.

Jacques Le RIDER, 1990: Das Ende der Illusion. Die Wiener Moderne und die Krisen der Identität. Prev. R. Fleck. Wien: ÖBV Publikumsverlag, Wissenschaftsverlag (Orig. Modernité viennoise et crises de l'identité).

Dagmar LORENZ, 1995: Wiener Moderne. Stutgart, Weimar: J. B. Metzler.

Agatha SCHWARTZ, 2008: Shifting Voices. Feminist Thought and Women's Writing in Fin-de-Siècle Austria and Hungary. Montreal: McGill-Queen's UP.

Irena SELIŠNIK, Marta VERGINELLA, 2013: The Desire to be Free: Marica Nadlišek Bartol and the Young Intelligentsia at the Turn of the 20th Century. Historijski zbornik LXVI/1, 101-120.

Elaine SHOWALTER, 1997: Sexual Anarchy: Gender and Culture at the Fin-de-Siècle. London: Bloomsbury.

Marija ŠKERJANC KOSTERCA, 1959: Vida Jerajeva. Diplomska naloga. Ljubljana: Filozofska fakulteta.

Jana ŠTAUS, 2011: Vida Jeraj. Pesnica slovenske moderne. Diplomska naloga. Maribor: Filozofska fakulteta.

Marta VERGINELLA, 2017: Slovenka: prvi ženski časopis (1897-1902). Ljubljana: Znanstvena založba Filozofske fakultete.

Vita ŽERJAL PAVLIN, 2017: Slovenkine pesnice. Slovenka: prvi ženski časopis (1897-1902). Ur. Marta Verginella. Ljubljana: Znanstvena založba Filozofske fakultete. 53-65.

Literarna zapuščina Vide JERAJ, Ms 1213, Rokopisni oddelek NUK-a v Ljubljani.

NEXT TO MY DOOR THE DEATH IS WAITING. LONGING FOR LOVE. LONGING FOR DEATH. VIDA JERAJ - SLOVENIAN DECADENT POETESS

The topics of my article are the decadent tendencies in the literary work and life of the first Slovenian female lyricist Vida Jeraj (Franica Vovk, 1875-1932) who was a vital part of the Slovenian modernist network ("Slovene moderna") in Slovenia and Vienna. Jeraj belonged to the generation of young cosmopolitan women writers who broke through in in the fin-de-siècle 
period in Slovene society, at that time the periphery of the Austro-Hungarian Empire. The starting point for the new Slovenian generation of women writers was the appearance of the newspaper Slovenka (Slovenian woman) in 1897 in Trieste. There, the circle of young female writers of prose and poetry was formed. They established their writer's and gender identity through a new style of behaving and acting in society: they were the prototypes of the "new women". The most distinguished poet from this circle was Vida Jeraj. She published just one anthology of poems (in 1908) and her voice disappeared also because of the poor and misogynist reception of her only book in the small Slovene society. She behaved as an extravagant, decadent female artist in her "period of being an independent young intellectual" in Zasip (1896-1901). For her writing and authorship the definition of her gender role was very important. In that context we must underline her personal crisis in the beginning of January 1901. For the first and last time in her correspondence she expressed the rebellion and the uncertainty of the subject whose personal identity - because of societal pressure ends in crisis.

The poems mostly in the classical ich form of confession are also the autobiographical stories of decadent love and death. She expresses changing moods from hope to despair and she balances from tradition to modernity, sometimes trying to be part of the traditional Slovenian folk culture and on the other hand expressing favour for the modern life in cities. In her formally very classical short poems she expresses a spectrum of modern feelings: there are meditative texts and ecstatic fragments depicting happiness on one side and on the other there are the expressions of a "sick soul", the feelings of nausea and tiredness, melancholy and sadness. The depressions of the subject intensifies into "cold cynic resignation" in her poems of love separation. In the short, minimalised poem Pri mojih durih čaka smrt (Next to my door the death is waiting) she depicts the nearness of death with almost gothic imagination. She - as a decadent writer - is attracted to death in some other poems as well: longing for life can in her case sometimes bring about a wish for death. 


\title{
Postcolonial identity in Yurii Andrukhovych's poetry: landscapes and dislocation
}

\author{
IRYNA BORYSIUK \\ National University of Kyiv-Mohyla Academy, Hryhoriya Skovorody St. 2, \\ UA-04655Kyiv, odnoklasnyk@ukr.net
}

1.01 Izvirni znanstveni članek - 1.01 Original Scientific Article

Postokolonialna teorija obravnava veliko pomembnih tematik, vprašanje identitete pa je ob dihotomiji moči/znanja in ob narativnih strategijah reprezentacije ključno. Analiza literarnega besedila omogoča prepoznavanje ideoloških sprememb $\mathrm{v}$ javnem diskurzu in posameznikovi zavesti, ki temelji na subjektovem jezikovnem vedenju. Postkolonialni pristop omogoča analizo izgradnje identitete in transformacije ter presečišče med govorečim subjektom in njegovimi različnimi identitetami. V tem kontekstu se poezija Jurija Andruhoviča izkaže kot zanimiv predmet obravnave. Oblikovanje subjekta in transformacijske strategije je mogoče preveriti s pomočjo ključnega koncepta pokrajine in dislokacije. Transformacija je prisotna $v$ kontekstu generacijske paradigme. Poezija temelji na generaciji iz osemdesetih let 20. stoletja in ponuja tematsko razširitev na poezijo generacije iz devetdesetih let, usmerjena pa je v podvajanje in širjenje tematskih vsebin.

Postcolonial theory deals with many important issues and the question of identity is a key one along with the power / knowledge dichotomy and the narrative strategies of representation. The analysis of literary text allows to identify ideological transformations in public discourse and individual consciousness which is based on subject's linguistic behavior. The postcolonial approach allows to analyze identity construction and transformation as well as the intersection between the speaking subject and its different identities. In this context, the poetry of Yurii Andrukhovych is an interesting object for reflection. Subject construction and transformation strategies can be examined through the landscape and dislocation key concept. This transformation is vivid in the context of generational paradigm. Based on the transition from the 1980s generation, this poetry provides subject expansion to the 1990s generation poetry, and is oriented towards the doubling and multiplying of subject.

Ključne besede: postkolonialna teorija, identiteta, subjektivnost, sodobna ukrajinska poezija, Jurij Andruhovič

Key words: postcolonial theory, identity, subjectivity, contemporary Ukrainian poetry, Yurii Andrukhovych 


\section{Introduction}

In contemporary Ukrainian literature, Yurii Andrukhovych is perceived a trickster mythical character. The trickster is a medial persona who is able to cross the line between worlds. The trickster is immoral and conventional good and evil categories are meaningless when estimating some of his/her acts. The trickster is responsible for situations that undermine the strict and monolithic world structure through parodying creation acts. Most importantly, the trickster imitates or parodies cosmogenic ritual acts, thus he/she is able to produce the controllable chaos in the world.

In his first poetry collection The Sky and Squares (1985) and the subsequent books, Andrukhovych demonstrates the border between the Soviet and post-Soviet epochs. Andrukhovych's main poems have been written in the late Soviet era but his poetry cannot be inscribed in the Soviet rhetoric paradigm. What is more intriguing, the poetry of Andrukhovych marks the border between the generations of 1980s and 1990s. Thus, the aesthetical paradigms of preceding and succeeding generations are combined in his writings. Ultimately, Andrukhovych's creative works become a turning point in the subsequent literary hierarchy collapse. The literary life during the 1990 s can be compared with that of 1920s: there are turbulent literary life and plenty of literary groups. The Bu-Ba-Bu (Burlesque - Booth - Buffoonery) literary group, founded by Andrukhovych and his counterparts in 1985, was the first one among a number of the 1990s literary groups. However, as I presume, Bu-Ba-Bu appearance can be considered, among other groups and phenomena of that time, as a parody of the Ukrainian Writers' Union that is the Soviet institution for literary life organization and control.

In Andrukhovych's writings, space conceptualization is a crucial mechanism for identity construction. Dislocations, conquests, adventures, pilgrimages, imprisonments, and military campaigns are existentially significant for the post-colonial uprooting and boundary-building, as well as for Andrukhovych's protagonist who constructs him/herself and is being created by the power discourse at the same time. There is no consensus on whether or not the term "colonial" should be applied for the facts connected with the Russian ${ }^{1}$ and Soviet Empire of its late period. Vitaly Chernetsky argues that the "three worlds" symbolic geopolitical model, as a base for theorizing about power distribution, dominates in postcolonial studies (Chernetsky 2007: 7). The rhetoric on which this symbolic geography is grounded admits exclusion of the Second World from the Western interpretational scheme. This scheme is bipolar as it describes the relationship of the First and Third Worlds. Invisibility of the Second World in postcolonial studies is caused to a certain extent

${ }^{1}$ There is no consensus on whether or not the colonial status of Ukrainian culture in the Russian Empire should be recognized. To illustrate, Oleh Ilnytzkyj draws attention to the fact of Ukrainian elite' participation in Russian imperial culture building. Ilnytzkyj insists that it would be an exaggeration to treat Ukrainian national identity as it was created in the first half of the 19th century in terms of Ukrainian culture subordination (Innytzkyj 2014). Alexandr Etkind prefers the term "internal colonization" based on the class and social approach but not the ethnic one. He proposes to analyze the Empire as the hierarchy including the subjects of power and subaltern objects (Etkind 2011). Yaroslav Hrytsak draws attention to the participation of Ukrainian elites in the Soviet political power as well as to the involvement of Ukrainians in imperial colonization processes (quoted in Horbyk 2016). 
by the reciprocal symmetry of the First World guilt and the Third World ressentiment ${ }^{2}$. According to this approach, the ruling center and the subordinated periphery asymmetry in the Second World can be interpreted in terms of the Second World internal hierarchy, beyond the universal three-part scheme. As Vitaly Chernetsky insists, "when direct challenges came to this continuing privileging of the First World as a synecdoche for the universal, they were formulated from the perspective of the Third World, and important and laudable as they have been, they perpetuated the exclusion of the Second World from global cultural models, now recast in the oxymoronic binary of the First vs the Third World, which can be found even in the work of otherwise forward-looking scholars" (Chernetsky 2007: 7).

David Chioni Moore's article "Is the Post- in Postcolonial the Post- in PostSoviet?" is one of the first attempts to call into question the universality of the three worlds geopolitical scheme. In this article, Moore anatomizes this three-part geopolitical model and analyses its essential prerequisite and the elements of this scheme. Moore argues that the core theoretical implications of postcolonial studies are based on racial and cultural difference and on territorial remoteness (Moore 2006: 15). However, Moore insists that Western colonization types, as described in his article, can be applied to the Russian (and after 1920 - to the Soviet) Empire. According to Moore, the classic type of colonization is based on economic, political, military, and cultural control, exercised over racially different people (Moore 2006: 21). The second type is the settler colonization and the third type, the dynastic one, is determined by the territories conquest of the neighbors (Moore 2006: 21). The fourth type, the reverse-cultural colonization, Moore describes as a specific Russo-Soviet phenomenon. ${ }^{3}$ Moore states that "Mittel-European capitals such as Budapest, Berlin, and Prague were therefore seen in Russia, at least by some, as colonial prizes, rather than as burdens needing 'civilizing' from their occupiers" (Moore 2006: 26). According to Moore, the Russian and Soviet colonization of Ukraine is described as the third and fourth type of colonization (Moore 2006: 26). In this context, Marko Pavlyshyn applies the term "cultural colonialism" to the Russian and later Soviet Empire. This type of colonialism produces a hierarchy of institutional and ideological values in which the colonizer is central, visible, universal and dominant, and the colonized, accordingly, described as marginal, invisible, subordinate and local (Pavlyshyn 1992: 43-44).

\footnotetext{
${ }^{2}$ As David Chioni Moore states, "One aspect of that commitment has been the reasonable belief that the First World has largely caused the Third World's ills, and an allied, lessjustifiable belief that the Second World's socialism was the best alternative. When most of the Second World collapsed in 1989 and 1991, the collapse resulted in the silences apparent in Shohat (=Shoah, I. B.), and it still remains difficult, evidently, for postcolonial theorists to recognize the postcolonial dynamic within the Second World" (Moore 2006: 20).

${ }^{3}$ What is indicative, all attempts of postcolonial studies applying in Russian scientific discourse are not very consistent. If Alexandr Etkind, as stated above, in his analyses of the Russian Empire colonialism mostly ignores the national factor, then Madina Tlostanova's book in her attempt of Soviet and Post-Soviet cultural situation interpreting is, as Chernetsky calls it, "a traumatized, melancholic utopia" (Chernetsky 2007: 46). Clearly, in the analyses of transcultural and postcolonial hybridity the traumatic experience of oppression that Russian and Soviet colonies have been forced to endure is omitted. For a detailed explanation of this metropolitan blindness - see (Chernetsky 2007: 41-46).
} 
Another important issue regarding literary texts is the correlation / intersection of postcolonialism and postmodernism ${ }^{4}$. It is more a question of postcolonial studies genealogy than political and aesthetic decussating. Vitaly Chernetsky states that postcolonialist discourse is regarded as "a supplement and augmentation of the scholarly discourse on postmodernism originating from Third World contexts" (Chernetsky 2007: 7).

The combination of postcolonial and postmodernist approaches is particularly effective for analyzing Ukrainian post-Soviet literature. As Chernetsky puts it, "I would like to assert, following Foster and Jameson, the understanding of "postmodernism' as a condition and logic of a cultural era (generally dated back to the 1960s) - that is, as this era's dominant rather than just a movement or a style (as the Russian literary critics have tended to view it)" (Chernetsky 2007: 13). In this case, postmodernism is interpreted as an attempt "to deconstruct modernism not in order to seal it in its own image but in order to open it, to rewrite it" (Foster 1983: xi). That is to say, dominant narratives of modernism interact with repressed or marginalized discourses along with other strategies of deconstruction (Foster 1983: xiii). According to Hall Foster, postmodernism is connected with the crisis of Western culture representations; therefore, categories which are considered to be universal and immutable, need revision and rewriting. One of these categories is the modernists' "utopian dream of a time of pure presence, a space beyond representation" (Foster 1983: xv). For this reason, the postmodernist "anti-aesthetic" project is linked to deconstruction and representation order rewriting as "we are never outside representation or rather, never outside its politics" (Foster 1983: $\mathrm{xv})$. In that regard, the postcolonial discourse as connected with expelled and marginalized groups is correlated with a postmodern strategy of universality and normativity deconstruction. The question of representation in liaison with identity construction cannot be separated from the issue of narrativity as long as it is the narrative wholeness that maintains the illusion of a unified, completed, and coherent identity (Hall 1996: 598). In this respect, the subject fragmentation (alienation, death) is important for the discussion. Fredric Jameson believes that decentering of the formerly centered subject is closely linked to "the end of the autonomous bourgeois monad or ego or individual" of the classical capitalism and nuclear family period (Jameson 1991: 15). Stuart Hall proposes the theory of three identities (Enlightenment subject, sociological subject, and post-modern subject) that follow one another in a historical perspective. The modern sociological subject identity is constructed as "interaction" between self and society, the private and the public, the "inside" and the "outside". It replaces the Enlightenment subject whose identity "was based on a conception of the human person as a fully centered, unified individual, endowed with the capacities of reason, consciousness, and action, whose 'center' consisted of an inner core which first emerged when the subject was

\footnotetext{
${ }^{4}$ This has been reflected in the studies of Marko Pavlyshyn $(1992,1994)$, Tamara Hundorova (2013), and Olena Yurchuk (2013). The more detailed postcolonial methodology implementation analysis has been made by Marko Pavlyshyn (2014). However, his investigation reveals the lack of modern methodology implementation in Ukraine.
} 
born, and unfolded with it, while remaining essentially the same - continuous or 'identical' with itself - throughout the individual's existence" (Hall 1996: 597-598).

According to the sociological understanding of identity, the subject's inner core is formed in the interaction between self and society, or in other words, in relation to significant others; therefore, "the fact that we project 'ourselves' into these cultural identities, at the same time internalizing their meanings and values, making them 'part of us', helps to align our subjective feelings with the objective places we occupy in the social and cultural world" (Hall 1996: 598). From this perspective, the subject's identity is formed as stitching the subject into the structure (Hall 1996: 598). On the contrary, stitching the post-modern subject into the structure is more complex: "The very process of identification, through which we project ourselves into our cultural identities, has become more open-ended, variable, and problematic. This produces the post-modern subject, conceptualized as having no fixed, essential, or permanent identity" (Hall 1996: 598). Hall states that "The subject assumes different identities at different times, identities which are not unified around a coherent 'self'. Within us are contradictory identities, pulling in different directions, so that our identifications are continuously being shifted about" (Hall 1996: 598).

In this context, terminological relevance in relation to the Second World literature is important, inasmuch as Fredric Jameson describes postmodernism as a phenomenon pertaining only to late capitalist societies. However, Chernetsky proposes the convincing evidence: "the first signs of the shift from modernism to postmodernism arose in the Second World more or less simultaneously with their appearance in the West" (Chernetsky 2007: 10). In the case of Ukraine, examples can be drawn from Ukrainian "chimeric prose" "initiated by Oleksandr Il'chenko's 1958 novel, Kozats'komu rodu nema perevodu, abo zh Mamai i chuzha molodytsia (The Cossack kin never wanes, or Mamai and the stranger woman), subtitled ukrains'kyi khymernyi roman z narodnykh ust (a Ukrainian chimeric novel derived from people's word - literally, "from the people's lips)" (Chernetsky 2007: 189). According to Chernetsky, Ukrainian chimeric prose fits into the postmodern / postcolonial paradigm. In addition, it should be noted that not only the genre approach but also the generational one is crucial. In the 1960s-1970s poetry (Oleh Lysheha, Hryhorii Chubai, and Taras Melnychuk) as well as in prose, the narrative strategy represents subject's decentralization and fragmentation.

The aim of this paper is to analyze the strategies of subject's postcolonial identity formation. Roman Horbyk's paper, "Ideologies of the Self: Constructing the Modern Ukrainian Subject in the Other's Modernity" (2016), is an interesting example of strategies for subject's identity construction in the colonial situation. Basing his analysis on Foucaultian subject / knowledge / power triangle, Horbyk investigates ideological implications in the 1920s fiction and articles in periodicals. In this paper, the author focuses on ideological prescriptions and didactic elements, inserting analyzed narratives in the Foucaultian knowledge / power configuration. My suggestion is that in Ukrainian literature of the last third of the 20th century the strict generational pattern, manifested in the transformation of the narrative subject, can be observed. For instance, in the poetry of the 1980s there is a subject's extension strategy, and this correlates with Stuart Hall's statement that modern 
subject's identification is a process of stitching the subject in the structure. It means that there is a national history and cultural context for the representatives of the 1980s generation. On the contrary, in the 1990s poetry doubling or even multiplication of the subject can be observed. This correlates with postmodern subject's characteristics and fits into "the play of identities" scheme (Stuart Hall's term) determined by inside and outside identity's contradictions and by its conceptual identification as a process of differentiation in contrast to unification. According to Kobena Mercer, "the political landscapes of the modern world are fractured in this way by competing and dislocating identification - arising, especially, from the erosion of the 'master identity' of class and the emerging identities belonging to the new political ground defined by the new social movements: feminism, black struggles, national liberation, anti-nuclear, and ecological movements" (quoted in: Hall 1996: 601). In post-Soviet Ukraine, this identification diversity is determined historically. There is a competition between nostalgic Soviet subject's integrity and incoherent post-Soviet subject whose identity cannot be constructed as "master" as this post-Soviet identity is determined by national, linguistic, gender, and class factors in different proportions. This is exactly why the postmodernism of the 1990s poetry cannot be defined from the perspective of the instrumentalist approach and conceptualized as an artistic style or manner. In fact, not all texts of this period contain the elements of intertextuality, carnivalization, and parodying, the free play of signifiers, the erosion of boundaries between mass and high cultures. On the contrary, the texts of the 1990s include doubling / multiplication of the narrative subject, features which are common for Maryana Savka's or Serhiy Zhadan's poetry. The 1990s poetry is characterized by the actualization of our / their voices differentiation, substitution and replacement narrative strategy, and plurality of the world.

\section{Toward the West}

In postcolonial theory, the term "dislocation" concerns "the experience of those who have willingly moved from the imperial 'Home' to the colonial margin" as well as "the extreme form of physical, social and individual dislocation involved in the institution of slavery". In other words, "The phenomenon may be a result of transportation from one country to another by slavery or imprisonment, by invasion and settlement, a consequence of willing or unwilling movement from a known to an unknown location" (Ashcroft 2007: 65). This terminological duality is reflected in the poetry of Yurii Andrukhovych. His poem The Kolomyia Regiment in Paris. 1815 (“Коломийський полк у Парижі. 1815”) most likely refers to the historic event on 20 November 1815 when the Treaty of Paris (the second peace treaty) was signed between France and Great Britain, Austria, Prussia and Russia. In this poem, Andrukhovych appeals to the traumatic issue of Ukrainian participation in other people's wars and, more importantly, in rival armies. Besides, his poetic cycle The Depictions of Battles ("Батальні сценки") includes the other texts alongside The Kolomyia Regiment in Paris. 1815 referring to World War I (Chernihiv Municipal Artillery - "Чернігівська міська артилерія") and to the Ukrainian liberation struggle of 1917-1921 as well as the October Revolution in 
Russia (Narbut's A. 1917 - “Нарбутове “A”. 1917”). In The Kolomyia Regiment, Andrukhovych describes a typical situation when the inhabitants of Ukrainian lands (and the people of Kolomyia as well) administrated by the Austro-Hungarian Empire were killed in imperial wars.

However, text's anticolonial orientation is less straightforward than readers anticipate: for its interpretation, the poem needs consideration of the different contexts. At first sight, The Kolomyia Regiment describes a typical situation of colonial dislocation through the native / foreign country opposition. Andrukhovych's textual strategy is based on the space / place dichotomy. The place emerges as a result of the interaction between landscapes and people. Paul Ricoeur argues that a space becomes open for our experience and observation in the process of interaction between human beings and lands (Ricoeur 2004: 206). The place is inserted in the hierarchies and cultural matrixes and is formed as a structure in the process of central / marginal and determinant / unessential issues interrelation. In postcolonial context, dislocation may take a form of converting "the uncolonized 'space' into colonized "place" exercising by language (Ashcroft 2007: 65). In the poem by Andrukhovych, linguistic appropriation of the alien space is conceptualized as a colonial process of mimicking. That is to say, Paris is described through the determinant (recognizable) places, such as Arc de Triomphe and the Palace of Justice ("oh you the palace of justice, the arch of triumphs"5 - "палаце правосудний тріумфів арко"), the Palace of Versailles ("the islands are floating in the river oh Versailles do waltz!" - “острови плинуть річкою вальсуй версале”), and the Seine river ("the ash-tree leaf is floating in the Seine" - "сеною плине яворовий листочок"). But the hierarchy formation is a process of stereotyping linked to the Other's glance. Paradoxically, Paris (or Europe, in a broad sense) becomes an object of linguistic and semantic appropriation. Widely reproduced in mass culture, the image of Frenchmen as wine lovers ("the war is over and there are seven barrels of wine" - “скінчилась війна і вина сім бочок") is a specific description originated from the language of the observer but not from that of the observed subject. But the most representative case of linguistic appropriation are linguistic games which are an important characteristic of Andrukhovych's literary style. For instance, the cross-linguistic homonymic effect built on hryzetky (French: grisettes) / hryzutsia (Ukrainian: gnawing) the sound of words ("grisettes are gnawing on the arks of balconies" - “на ковчегах балконів гризуться гризетки”) is the playful integration of Other in the native language space. This playfulness is an ironic deconstruction of "the plucked roosters" (“обскубаних когутів") and the heartbreaking laments of "soldiers with burned mugs" (“вояцтва з обгорілими писками”).

According to this principle, the native land space is formed as well. The Kolomyia recognizable image as a capital of Easter eggs painting (the unique Museum of Easter Egg and the Easter Egg Monument are in Kolomyia) is manifested through the body-map metaphor. There are the human body ("we are painted by sobers that are sort of blades we are glowing with our many wounds" - "розмальовані шаблями ніби бритвами / світимося наскрізно рана на рані”) and the terra's body ("have we ever come to you the capital of our pain you are kolomyia the

\footnotetext{
${ }^{5}$ Here and further translation from Ukrainian is mine, except "Jamaica the Cossak".
} 
easter egg you are kolomyia the city” - “чи ж дійдемо до тебе столице нашого болю / коломиє писанко коломиє місто”). In this way, Easter egg ornaments are conceptualized as writings that describe the traumatic experience of soldiers. The inversion of sense is clearly seen - in the Easter ritual, the clear egg's surface painting is a cosmologic metaphor. On the other hand, a human body or a terra's body is seen as a map of loss, a destruction and dismemberment visual metaphor. Divided by imperial borders homeland and scarred by the war, bodies are symbolically identified through the metaphor of writing. In other words, Ukrainian soldiers are not only inserted into a strange space ("we are the ones who have camped in the heart of Paris" - "а то ми серед парижу табором стали") but they also mark this space with their native language. Moreover, linguistic markers include their textual and ideological patterns as well. In his poem, Andrukhovych uses dialect Galician words. In this case, the language becomes not only the way of establishing "the Galician camp" in Paris but also the dismantling of linguistic norms. That is to say, Andrukhovych combines the time of narration and that of reading, reaching ironic effect.

This irony is based rather on the context and is outlined by the time of reading and the reader's experience than on textual senses. Yet, in the reader's present time, there is a Ukrainian myth of Europe originating in the trauma of elimination and desire - something that could not happen in 1815 as described by Andrukhovych. The irony is linked with different contexts related to the contemporary myth of Europe. In this myth, Paris is a quintessence of desired Europe and Arc de Triomphe with other places become the objects of tourists' consumption but not the places where the historical drama emerged. Andrukhovych's irony outlines the Austro-Hungarian Empire utopian vision. According to this point of view, the Empire is not the metropolitan power but it is Europe from which Ukraine has been brutally separated.

\section{Inside the Empire}

The other story of dislocation refers to other empire. The poem Vania the Cain ("Ваня Каїн"), as Andrukhovych has noted in the motto, is based on "the old Moscow picture book (lubok)". Van'ka Cain's literary biographies and picture books, which can be viewed as an analogue of mass literature, were extremely popular in the eighteenth century Russia amongst the townsfolk and merchants. Van'ka Cain, whose real name was Ivan Osipov (1717-1756), was not only the famous burglar and robber but also the outstanding organizer who integrated the criminal world into Moscow police. In 1748, this resulted in the mass terror in Moscow, further leading to anarchy and paralyzing power institutions. Osipov's nickname can be easily explained by his cooperation with the police as he surrendered low-level criminals and harbored major ones.

In fact, Vania the Cain demonstrates the deconstruction of the Soviet / Russian myth. It should be noted that the key argument, determining the post-colonial researches' reluctance to analyze the Second World in terms of post-colonial methodology, is the approval of the racial, linguistic, and religious similarity of the colonizer and the colonized, taking into account Russia's colonial domination 
over Slavic countries, Ukraine and Belarus. It is difficult to say now if this scholarly prejudice is linked with the myth of the three fraternal nations thoroughly cultivated by Russia. However, this myth becomes fatal for Ukraine in the current Ukrainian-Russian war. Andrukhovych refers to this propagandist myth, veiling it under the other historical plot: the Russian "brother" turns out biblical Cain.

Similar to The Coloma Regiment, Vania the Cain is based on our / their land opposition. Yet in The Coloma Regiment, a foreign land is not a colony opposed to a metropolis but a neutral space (however, when being read in the context of the modern Ukrainian myth, it plays a role of the Europe metonymic substitution). In Vania the Cain, a foreign land is the territory of the enemy which absorbed the colony. Our / their asymmetry is absolute as the empire represented in the textual space takes the place of the lyrical subject's native land, marked by the words "the bright stars" ("ясні зорі"). Driven from its space by the empire, homeland becomes not only invisible but also unnamed, and the paraphrase "the bright stars" which is a reduced form of the idiom "to the bright stars, to the calm water" ("на ясні зорі, на тихі води") does not identify Motherland but just points at it.

The colonial dislocation plot of Vania the Cain is more tragic than the military drama of The Kolomyia Regiment. However, this plot refers to Andrukhovych's The Moscoviad ("Московіада") (1992). Wandering around the metropolis center, the protagonist of this novel, Otto von F., finds both horizontal and vertical (spatial and symbolic) imperial dimensions and returns finally to Ukraine with a bullet in his skull. In Vania the Cain, the source of voice is discovered in the poem's last verse; thus, the subordinated object is replaced with the speaking subject. The intertextual game is actualized by an allusion to the biblical context: "you who are quick with your fraternal hands / give me a drunken embrace / let me go to the bright stars / I am immortal now and you are not my keeper anymore" (“братні руки до розправи скорі / для обіймів п’яних розпросториш / відпусти мене на ясні зорі / я вже вічний ти мені не сторож").

The biblical phrase “Am I my brother's keeper?" (Genesis 4:9) is not only a key for reading the plot of this poem but also a marker for ideological and linguistic dismantling of the imperial myth and for the inscription of the colonized subject into discursive space. There is inversion of speaking subjects - in the Bible, Cain is a narrating and acting subject; however, the killed "brother" of Andrukhovych's text is able to tell his own truth. In this way, Andrukhovych deconstructs the hierarchy based on language / power interaction. The power relation dichotomy is called into question by the colonized subject's linguistic representation; this subject not only manifests its presence through the speaking act but also builds a narrative in which the empire is described from the viewpoint of the colonized subject.

In The Coloma Regiment, Paris is described through real and symbolic topography; in the "Russian kingdom" (“в руськім царстві”), however, concrete loci are denoted through culturally produced meanings. These meanings are constructed from the colonized subject's viewpoint: the imperial space is marked by traumas, repressions, and violence. Moscow here, as in The Moscoviad, is a center of the metropolis: "for whipping again at the stables / from Moscow to the very to Alaska” (“знов на стайнях батогом пороти / від москви до самих до аляски"). The locus of Moscow is inscribed in Andrukhovych's text as a line from 
The Song about Motherland (1936) by Vasilii Lebedev-Kumach - "from Moscow to the very margins / of my immense Motherland” (“от Москвы до самых до окраин / необьятной Родины моей”). This song was so recognizable in the Soviet Union that it claimed to be the official hymn of Russia after the collapse of the Soviet Union; the song's first chords were the main theme of the Soviet Union Broadcasting. The other Andrukhovych's significant topos is the Yenisei which is conceptualized in this context as a metonymy of Siberia: "you are tearing your shirt off and my skin having been peeled off me somewhere on the Yenisei is under your shirt"6 ("рвеш сорочку та під нею шкіра / здерта 3 мене десь на єнiceï"). This concealed collective trauma (a mass eviction of the Ukrainians to Siberia in 1920-1950 as well as their mass executions and their imprisonment in Soviet labor camps) is represented through the reference to the concrete locus and treated simultaneously as a place of remembrance. Therefore, the speaking subject not only constructs his narrative through the nominative practice, that can be conceptualized as a linguistic appropriation of things and places, but also re-orders a symbolic space of the empire from the standpoint of the colonized subject and its traumatic experience.

Cultural stereotypes used by Andrukhovych in his poems are geared to creating the counter-narrative by dismantling the position of colonizer who has a privilege to be the only subject of speaking and observing. Such obsessive observation is a powerful instrument of the imperial domination as surveillance "objectifies and interpellates the colonized subject in a way that fixes its identity in relation to the surveyor" (Ashcroft 2007: 207). The exercise of power over the space includes obtaining "the position of panoramic observation, itself a representation of knowledge and power over colonial space" (Ashcroft 2007: 208). Andrukhovych exercises an ideological inversion of the imperial strategy: in his poems, the observer and the observed are reversed, and the colonizer is an object of observation, estimation, analyses, and representation. This is counter-narrative produced by the colonized. In Andrukhovych's text, the Russian empire consists of cultural stereotypes rooted in public consciousness. It is heavy drinking of the Russians ("in the Russian kingdom, there is a bender again / and even pigeons on temples are livid with boozing” - “знову в руськім царстві пиятика / навіть голуби на храмах сизі"), their propensity for violence ("for whipping again at the stables" - "знов на стайнях батогом пороти", “уоu are stomping on it just like you have stomped on ${ }^{7}$ the foreign princess" - “топчеш, як топтав чужу князівну”), and a specific zoo- and geo-symbolism outlining Russia as a land of cold, Arctic nights and wild bears ("you are tearing your caftan off as if you are dying / at this immense winter bear night” - “рвеш каптан бо ніби й справді гинеш / у безкраю ніч ведмежу й зимну”). However, Andrukhovych's poems are more based on the literary background than on social stereotypes and prejudices. Represented as specifically Russian, predisposition for being the object and subject of violence ("you are the dark mouth looks like a Russian shirt / you are the one who pray

\footnotetext{
${ }^{6}$ The Russian idiom to tear one's shirt off (rvat' na sebe rubashku) has a meaning of expressing one's feelings explosively.

${ }^{7}$ The sense is "to rape the foreign princess".
} 
to God rather for his thong than for his mercy / who pray for whipping again at the stables / from Moscow to the very to Alaska" - "мій косоворотий темний роте / в Бога просиш різки паче ласки / знов на стайнях батогом пороти / від москви до самих до аляски") refers to Dream by Taras Shevchenko. Besides, "the axe that has fallen from heaven into mountains" (“сокира, що з небес упала у недеї”) might be Raskolnikov's axe as well. Through these implicit allusions Andrukhovych, like Les Poderevianskyi with his play Pavlik Morozov, refers to the Godbearing people concept rooted in Russian culture and deconstructs it at the same time. The textual strategy of inversion and dislocation works to construct the de-colonized subject who not only becomes the source of glance and voice but also creates his own narrative.

\section{The Exotic Otherness of Self}

Andrukhovych's other poem, Jamaica the Cossak, which can be described as a dislocation text, is much more controversial from the viewpoint of subject-constructing strategy. Jamaica the Cossak ${ }^{8}$ is the most representative text regarding the postcolonial discourse in Ukrainian literature (see Pavlyshyn 1994). This unexpected mixture of Ukrainian reality and Caribbean exoticism have been conceptualized as the postmodern game with different cultural contexts and the implicit juxtaposition of Ukrainian and other post-colonialisms, in particular Caribbean (Chernetsky 2007: 216). First of all, unforced dislocation in Jamaica the Cossak is a sign which indicates the position of the colonizer but not the colonized: "on this side is bahama mama on the other palms of Haiti / at night stepping out of the bungalow i see the towers of freetown" (“по сей бік багама-мама по той бік пальми гаїті / і вежі фрітауна бачу як вийду вночі з бунгало”), “when father wanted to take that blessed place, freetown" (“а батько ж хотіли взяти отой блаженний фрітаун”). In the poem, Andrukhovych constructs the speculative situation describing numerous Cossacks' see campaigns as if they would have been included in the foreign conquests context. The Freetown conquest (Chernetsky pays attention to the etymological symbolism - (Chernetsky 2007: 216)) can be interpreted as a metaphor of Ukraine's freedom and independence. In that case, an allusion to Ukrainian Liberation battles of the $17^{\text {th }}$ and $18^{\text {th }}$ Century is quite reasonable as well as allies' betrayal topos that is common for Ukrainian folklore and literature: "the sea mowers-corsaires betrayed us in the battle" (“та й зрадили нас у битві морські косарі корсари”).

However, I believe that the poem's deeper sense is revealed in the collaboration of the Cossak and the drinking episode of the pirate with the phallic name Dick. The pirate's name is not a coincidence or a sign of Andrukhovych's spontaneous wit, it is a problematization of desire in the context of which women's and terra's bodies that have to be conquered are converged: "when father wanted to take that blessed place, freetown / there they have thirteen churches and an eternal war with cupid / and also thirteen abysses where silver and gold are hidden / young girls there are like vines growing quietly behind the walls / they're dying to make love

\footnotetext{
${ }^{8}$ The poem is translated by Vitaly Chernetsky.
} 
but they’ve been dressed in black” (“а батько ж хотіли взяти отой блаженний фрітаун / а там тринадцять костьолів і вічна війна з амуром / а там тринадцять безодень де срібло-злото коморне / дівчата немов ліани нечутно ростуть за муром / і хочеться їм любитись а їх зодягли у чорне"). A delayed / prohibited sexual desire, embodied in the images of nuns, is correlated with the refusal of domination / rootedness: "he says i have a slave girl with skin the color of cocoa/ buy her oh my grey eagle it's tough without a woman / no need to plant a garden he adds chuckling slyly / a garden grows out of her body with tobacco pineapples melons / you'll make a lot of little Cossacks take all of them into your host / however my neck my soul does not yield to a yoke” (“невільницю каже маю зі шкірою мов какао / купи сизокрилий орле маркотно ж без господині / город засівати не конче прицмокує так лукаво / город на ній проростає тютюн ананаси дині / наплодиш каже козацтва припнеш усіх до коша / тільки ж ярму не дається шия моя душа"). The symbolic woman and terra identification is provided through the fertility concept: a woman as the terra gives birth both to plants and descendants, "the little Cossacks". But why this rooting in a land and family is treated as a yoke?

This fact can be explained through the nomadism of a Cossak whose lifestyle of a warrior / merchant is based on the family temporary refusal. On the other hand, it can be explained through the anti-colonial pathos (human being is not a commodity to be bought and sold). Interestingly, the pirate presents the position of supremacy (to buy a slave girl, to establish a colony-family) but the Cossak rejects a yoke. This episode is a key one for the interpretation of the poem. In fact, opposite concepts (supremacy / subjection) belong to the binary black and white worldview: "to be or not to be he says and burps I'm sorry" ("to be or not to be каже і булькає I'm sorry"). Supremacy in this case is a base of subjection, and domination means dependence. Absolute freedom is a mirage, utopian Freetown that will never be reached. Through this opposition, the motif of Dick's betrayal can be explained: "is it really that if you're European you don't have to be a man / why the fuck have you sold yourself for thirty rotten escudos" (“невже коли ти європа то вже не єси чоловіком / якого хріна продався за тридцять гнилих ескудо"). As can be seen, the betrayal of freedom means taking away the other's freedom.

For this reason, this text can hardly be called the postmodern frivolous and frisky result of an irresponsible play with cultural symbols. As well as in his poem Vania the Cain and novels The Moskoviad and The Perversion, Andrukhovych eliminates his hero from the final scenes. However, is it really the hero's death or his nonexistence? Otto von F. from The Moskoviad, with the bullet in his skull, goes in a train going from Moscow to Kyiv and thinks about Ukrainian history and geography. Stas Perfets'kyi from The Perversion had left the trace as an evidence of his return. The protagonist of Vania the Cain is speaking from the world of death and his voice is the evidence of his existing. And Jamaica the Cosssak's exclusion is not only the symbol of human mortality. Jamaica the Cossak does not want to belong to the black and white world where there is no alternative to the domination / oppression frame: "I will go out at sunset / make a flute out of sugar cane / sit down by the ocean / and now I am no more" (“піду на зорю вечірню зріжу цукрову сопілку / сяду над океаном та вже мене і нема”). 
In all these cases Andrukhovych uses the specific narrative strategy that can be conceptualized as discourse inversion of the colonizer. Thus, the speaking subject appropriates this disparaging, full of stereotypes, black-and-white narration of the Other and constructs its own narration through the power discourse inversion and parody.

In a symbolic way, this narration not only dismantles the empire as the narrative object but also ruins the very imperial discourse through reducing the imperial narrative of the Other to absurdity. Denudating the mythic matrix of the human / natural, on which the Self-Other opposition is based, Andrukhovych deconstructs the treatment of Other as non-human.

\section{Conclusion}

In Yurii Andrukhovych's poetry, subject is constituted through the space and body nexus. However, dislocation as a key factor of colonial identity construction becomes a mechanism for the dismantling of the colonizer / the colonized dichotomy. The inversion used in Andrukhovych's poetry calls into question the normativity of the power discourse as well as the Self / Other dichotomy. Space conceptualization depends on configuration of the space type inscribed in a power discourse network. In the poetry by Andrukhovych, there are three types of space configuration. The first type is a native space which is colonized; the second type is an imperial space which is a source of colonial power. The third type is an exotic space which is an object of colonial desire and linguistic appropriation. The last type marks the inversion of power relations and the dismantling of the colonizer / colonized dichotomy.

Andrukhovych's poetry reflects the transition between the colonial and postcolonial conditions. From this perspective, Andrukhovych's texts are more than a cultural game with signifiers through fundamental postmodern irony. The postmodern construction in his poetry is ideologically determined by monolithic narratives dismantling postcolonial strategies. These strategies are the most obvious in tension between Self and Other, especially when Self / Other space mapping means dislocation, shifting boundaries, construction of masks and characters. Deconstruction of ideological narratives and frames, conceptualized as universal, is exercised in different ways, for instance, through parodying, shifting the focus, speaking out displaced / unspeakable, hierarchy destruction. These techniques bolster the linguistically adequate narrativization of the Self. Importantly, the linguistic modus helps to identify fragmentation of the speaking subject of the postcolonial identity.

\section{REFERENCES}

Yrii ANDRUKHOVYCH, 2002: Екзотичні птахи і рослини (Exotic birds and plants). Ivano-Frankivsk: Lilea-NV.

Bill ASHCROFT, Gareth GRIFFITHS, Helen TIFFIN, 2007: Post-colonial studies: the key concepts. New York: Routledge.

Vitalii CHERNETSKY, 2007: Mapping postcommunist cultures: Russia and Ukraine in the context of globalization. Montreal: McGill-Queen's University Press. 
Alexander ETKIND, 2011: Internal colonization: Russia's imperial experience. Cambridge: Polity Press.

Hal FOSTER, 1983: Postmodernism: a preface. The Anti-Aesthetic: essays on postmodern culture. Ed. Hal Foster. Seattle: Bay Press. ix-xvi.

Stuart HALL, 1996: The Question of cultural identity. Modernity. An introduction to modern societies. Ed. Stuart Hall, David Held, Don Hubert, Kenneth Thompson. Malden: Blackwell. 596-632.

Roman HORBYK, 2016: Ideologies of the self: constructing the modern Ukrainian subject in the Other's modernity. Kyiv-Mohyla Humanities Journal 3, 89-103.

Tamara HUDOROVA, 2013: Транзитна культура. Симптоми постколоніальної травми (Transit Culture. The Symptoms of Postcolonial Trauma). Kyiv: Grani-T.

A hundred years of youth: A bilingual anthology of 20th century Ukrainian poetry, 2000. Ed. Olha Luchuk, Michael M Naydan. Lviv: Litopys.

Oleh ILNYTZKYJ, 2014: Роздуми про “культуру" в імперії (3 перспективи російськоукраїнських взаємин, 1800-1850). Постколоніалізм. Генераціï. Культура (Postcolonialism. Generations. Culture). Ed. Tamara Hundorova, Agnieszka Matusiak. Kyiv: Laurus.

Fredric JAMESON, 1991: Postmodernism, or The cultural logic of late capitalis. Durham: Duke University Press.

David Chioni MOORE, 2006: Is the post- in postcolonial the post- in post-Soviet? Toward a global postcolonial critique. Baltic postcolonialism: a critical reader. Ed. Violetta Kelertas. Amsterdam, New York: Rodopi. 11-43.

Marko PAVLYSHYN, 1992: Postcolonial features in contemporary Ukrainian culture. Australian Slavonic and East European Studies 6/2, 41-55.

- -, 1994: Козаки в Ямайці: постколоніальні риси в сучасній українській культурі. Slovo i Chas 4-5, 65-71.

--, 2014: Постколоніалізм як метод і склад думки. Спостереження щодо українського літературознавства на сторінках журналу “Слово і час" у роках 1991-2011. Постколоніалізм. Генерації. Культура (Postcolonialism. Generations. Culture). Ed. Tamara Hundorova, Agnieszka Matusiak. Kyiv: Laurus. 73-83.

Olena YURCHUK, 2013: Утіні імперії. Українська література у світлі постколоніальної meopiï (In the Shadow of the Empire. Ukrainian Literature from the Perspective of Postcolonial Studies). Kyiv: Academia.

\section{POSTKOLONIALNA IDENTITETA V POEZIJI JURIJA ANDRUHOVIČA: POKRAJINE IN DISLOKACIJE}

Jurij Andruhovič je ključna osebnost v ukrajinskem literarnem procesu zadnje tretjine dvajsetega stoletja. Njegova poezija označuje mejo med sovjetsko in postsovjetsko dobo ter med generacijami osemdesetih in devetdesetih let prejšnjega stoletja. Dislokacije, osvajanja, pustolovščine, romanja, zapori in vojaške akcije so eksistencialno pomembne za postkolonialno izkoreninjenje in ustvarjanje meja ter za Andruhovičev lirski subjekt, ki ga oboje določa in ki ga ustvarja diskurz moči. Konceptualizacija prostora je v tem pogledu ključni mehanizem za oblikovanje identitete.

V Andruhovičevi poeziji obstajajo tri vrste konfiguracije prostora: 1) domači kraj, ki je koloniziran; 2) imperialistični prostor, ki je vir kolonialne moči, in 3) eksotični prostor, ki je predmet kolonialne želje in jezikovne prisvojitve. Slednji označuje inverzijo razmerij moči in uničenja kolonizatorja oz. kolonizacijske dihotomije. Andruhovič v svojih pesmih 
dekonstruira hierarhijo, ki temelji na interakciji jezik-moč; pri tem je podrejeni predmet nadomeščen z govorečim subjektom. Tekstualna strategija inverzije in dislokacije deluje na oblikovanje dekoloniziranega subjekta, ki ne postane le vir pogleda in glasu, temveč ustvarja tudi svojo zgodbo. V poeziji Jurija Andruhoviča je subjekt oblikovan skozi prostorsko-telesno povezanost. Dislokacija kot ključni dejavnik izgradnje kolonialne identitete pa postane mehanizem za uničenje kolonizatorja oz. kolonizacijske dihotomije. 


\title{
Spodbujanje družinskega branja v otrokovem predšolskem obdobju: Predšolska bralna značka
}

\author{
Dragica Haramija \\ Univerza v Mariboru, Filozofska fakulteta, Koroška cesta 160, \\ SI-2000 Maribor,dragica.haramija@um.si
}

1.01 Izvirni znanstveni članek - 1.01 Original Scientific Article

\begin{abstract}
$\mathrm{V}$ prispevku ${ }^{1}$ se osredinjamo na razvijanje družinskega branja, ki je eden od temeljev Predšolske bralne značke (PBZ). S pomočjo ankete smo zbrali rezultate o vključenosti otrok v PBZ in opise drugih dejavnosti, ki spodbujajo družinsko branje. Zanimalo nas je tudi delo mentorjev branja, predvsem načini izbiranja priporočenih gradiv za branje $\mathrm{v}$ krogu družine in metode preverjanja prebranega. V sklepnem delu so podane smernice za pripravo kakovostnih bralnih seznamov, ki so lahko v pomoč staršem in otrokom pri izboru bralnih gradiv. Spodbujanje družinskega branja je tudi eden od ciljev predloga Nacionalne strategije za razvoj bralne pismenosti (2017), ki skrbno presoja tudi specifične cilje in ravni pismenosti od otrok v predšolskem obdobju do odraslih.
\end{abstract}

The paper focuses on the development of family literacy (family reading), which is one of the foundations of the Pre-school Reading Badge (Predšolska bralna značka, PBZ). With the help of the survey, we obtained relevant information on the involvement of children in PBZ and descriptions of certain other activities that promote family reading. We were also interested in the work of reading mentors, especially in the ways of choosing the recommended materials for reading in the family and in the methods of verifying the material read. The concluding part of the paper provides guidelines for the preparation of quality reading lists with the goal of helping parents and children to select proper reading materials. Promoting family reading is one of the objectives of the National Strategy for the Development of Reading Literacy (2017), which carefully assesses the specific goals and levels of literacy from children in pre-school age to adults.

Ključne besede: družinsko branje, bralna pismenost, Predšolska bralna značka, otroška literatura

Key words: family reading, reading literacy, Pre-school Reading Badge, children's literature

\footnotetext{
${ }^{1}$ Prispevek je nastal v okviru Raziskovalnega programa št. P6-0156 (Slovensko jezikoslovje, književnost in poučevanje slovenščine, vodja programa prof. dr. Marko Jesenšek), ki ga sofinancira Javna agencija za raziskovalno dejavnost Republike Slovenije iz državnega proračuna.
} 


\section{Uvod}

Definicije pismenosti se z raznolikostjo medijev, v katerih in s pomočjo katerih človek komunicira, vedno hitreje razvijajo, zato velja poudariti, da definicija pismenosti ni ena sama, sploh pa ne dokončna. Če je, kakor poudarja Mara Cotič (2011: 11), »/p/ojem pismenosti /.../ prvotno kot protipomenka pojma nepismenost označeval zgolj sposobnost branja in zapisovanja«, v sodobnosti pismenost pomeni nujnost bralnega razumevanja in sporazumevanja kot vseživljenjskega procesa za funkcioniranje vseh ljudi.

Družinsko pismenost razumemo kot različne dejavnosti znotraj družine, povezane $\mathrm{s}$ pismenostjo $\mathrm{v}$ najširšem pomenu besede, ko hkrati sodelujejo različne generacije in se skupaj učijo (Knaflič 2002: 38). V izobraževalnem pomenu vključuje napredek pismenosti vseh družinskih članov oz. jo interpretiramo kot vsako dejavnost, pri kateri družinski člani uporabljajo bralne, pisne ali računske spretnosti v družinski skupnosti v vsakdanjem življenju. Vključuje pa tudi bralno kulturo in navade, povezane s pismenostjo (Knaflič 2002: 38). Ob raziskavi pismenosti pri odraslih Knaflič ugotavlja:

Močan vpliv pismenosti staršev na raven pismenosti otrok, ki je razviden iz raziskovalnih ugotovitev, kaže, da se določena raven pismenosti medgeneracijsko ohranja znotraj družine ter da šola $v$ povprečju $\mathrm{v}$ majhni meri nadoknadi primanjkljaje na področju pismenosti, ki izvirajo iz družine. (Knaflič 2002: 42)

Marjanovič Umek, Hacin in Fekonja Peklaj (2018: 10) opozarjajo na kompenzacijsko vlogo vrtca pri razvoju otrokove pismenosti. Poudariti je treba tudi nujne pogoje za otrokov bralni razvoj in razvoj veščin bralne pismenosti, ti so bili sprejeti najprej v okviru UNESCA, povzema jih tudi Mednarodna federacija knjižničnih združenj IFLA in številni avtorji: dostopna primerna bralna gradiva, ki jih ima otrok doma, obisk knjižnice, odrasli, ki otroku bere in se z njim o prebranem pogovarja in je obenem otroku tudi bralni zgled, kar pomeni, da ga otrok vidi, da bere (Krolak 2006: 4, IFLA 2006, Jug, Vilar, 2015: 1304).

Ozaveščanje staršev o dejavnostih, povezanih z družinsko pismenostjo, so zelo pomembne, ali kakor v uvodu priročnika za spodbujanje družinske pismenosti Branje za znanje in branje za zabavo sporoča Livija Knaflič (2009: 6): »Spodbude staršev v veliki meri izhajajo iz njihovih lastnih družinskih izkušenj, kaže pa se, da se raven pismenosti ter bralna kultura prenašata medgeneracijsko.« V predbralnem obdobju je otrok predvsem poslušalec in ne bralec književnih besedil, zato ob sebi potrebuje odraslega, ki je pismen oz. ima odrasli posrednik razvite kompetence bralne pismenosti, da lahko sebi in otroku pomaga delovati v družbi. V predbralnem obdobju otrok (poslušalec) nima avtonomije pri izbiranju knjig, ki bi jih želel poslušati. Otrok tudi premalo pozna književnost in ima premalo »bralnih « izkušenj, da bi zmogel sam izbirati književna dela. Odvisen je od posrednikov: kaj mu bodo brali, kolikokrat so mu pripravljeni prebrati književno delo, ki mu je všeč, kdaj mu bodo brali, kako dolgo mu bodo brali, ali mu bodo sploh brali. Posredniki bi za otrokovo lažjo pot v svet pismenosti morali poskrbeti tudi za razvoj njegovega glasovnega zavedanja, ki ga razvijamo »v raznovrstnih dejavnostih igranja z besedami, npr. prepoznavanje in oblikovanje rim in aliteracije, prepoznavanje dolžine 
besede in torej ločevanje med dolgimi in kratkimi besedami, členjenje vezane govorice na besede, členjenje besed na zloge in glasove, spajanje zlogov in glasov v besede ter odvzemanje, dodajanje in nadomeščanje zlogov in glasov v besedah « (Medved Udovič 2011: 40).

Knjižna vzgoja kot povezanost branja leposlovja in informativne literature za otroke ter knjižnične vzgoje (informacijska pismenost) v najširšem pomenu prispevata k družinski pismenosti, ki ima dobro osnovo za vseživljenjski razvoj pismenosti kot temelja za pot do znanja. Sonja Pečjak in Ana Gradišar (2015: 59 po Dufdfy in Roehler 1993) predstavljata model povezanosti med komunikacijskimi sposobnostmi in pismenostjo, pri čemer sta govorjenje in pisanje produktivna dejavnost za tvorjenje sporočil, poslušanje in branje pa receptivna dejavnost za sprejemanje sporočil. Odrasli posrednik bi moral imeti razvite receptivne in produktivne bralne zmožnosti, da lahko z otrokom stopa na polje družinske pismenosti. Dejavnosti, povezane z družinsko pismenostjo, so v predšolskem obdobju najbolj tesno povezane $\mathrm{z}$ otrokovim govornim razvojem. Ljubica Marjanovič Umek, Simona Kranjc in Urška Fekonja so v monografiji Otroški govor: razvoj in učenje (2006) med drugim predstavile razvoj otrokovega govora, sporazumevalne spretnosti, dejavnike govornega razvoja in spodbujanje tega (tudi skozi simbolno igro). Avtorice ugotavljajo, da imajo na razvoj otrokovega govora pomemben učinek sociodemografske značilnosti družine (Marjanovič Umek idr. 2006: 53). Menimo, da je treba pri družinski pismenosti pozornost usmeriti predvsem k tistim družinam, ki so v deprivilegiranem položaju oz. da je še posebej treba spodbujati tiste družine, ki se znajdejo v marginaliziranem položaju ali so iz različnih razlogov družbeno izključene, npr. zaradi nezadostnega znanja slovenščine (migranti, priseljenci, Romi ....). ${ }^{2}$

Družinska pismenost ${ }^{3}$ je del bralne pismenosti, ki vključuje medgeneracijsko branje na vseh področjih dejavnosti (jezik, umetnost, družba, narava, matematika, gibanje) ter na vseh področjih otrokovega razvoja (kognitivnem, socialnem, čustvenem, estetskem, moralno-etičnem in motivacijskem področju). Razumemo jo kot različne dejavnosti znotraj družine, povezane s pismenostjo v najširšem pomenu besede, ko hkrati sodelujejo različne generacije in se skupaj učijo. Bralne pismenosti ne razumemo zgolj kot branje besedila, temveč razumevanje besedila kot prepleta jezikovnih in nejezikovnih znakov, gre za t. i. multimodalna besedila, $\mathrm{v}$ njih poleg besed, besednih zvez, stavkov in njihovih pomenov beremo tudi druge

${ }^{2} \mathrm{~V}$ raziskavah o povezanosti med socialno-kulturnim okoljem prebivalstva $\mathrm{v}$ posameznih regijah in dosežkih učencev na nacionalnem preverjanju znanja so Žakelj in Ivanuš Grmek $(2010,2011,2013)$ ugotovile, da imajo socialno-kulturni dejavniki velik vpliv na razvoj in šolski uspeh posameznika. Ta ključna ugotovitev, ki je izpeljana iz preučevanja rezultatov PISE, mora biti temeljno vodilo razvoja bralnih strategij, da bi izboljšali pismenost celotnega prebivalstva, predvsem pa da bi ozavestili in opolnomočili starše predšolskih otrok, kako pomembna je sposobnost branja in pisanja za človekov vseživljenjski razvoj.

${ }^{3}$ Smernice modela družinske pismenosti so nastale v okviru projekta V objemu besed (20162017), projekt je financiralo Ministrstvo za kulturo RS; pripravile so jih Dragica Haramija, Janja Batič, Katja Košir, Mira Krajnc Ivič, Marta Licardo, Alenka Lipovec, Simona Pulko, Marija Ropič, Polona Vilar, Tina Vršnik Perše, Melita Zemljak Jontes. Smernice modela družinske pismenosti so namenjene vsem družinam, pri čemer menimo, da so hkrati temelj izvedbenega kurikula na vseh področjih dejavnosti v vrtcu. 
nejezikovne znake (slike, tabele, fotografije, risbe ...). Potreben pogoj za razvijanje bralne pismenosti je dostopnost do kakovostnih bralnih gradiv. Otroci naj bodo čim bolj izpostavljeni bralnemu gradivu doma, v vrtcu (bralni kotički) ter šolskih in splošnih knjižnicah, kjer je članstvo zanje brezplačno.

\section{Predstavitev rezultatov}

V nadaljevanju predstavljamo rezultate ankete o Predšolski bralni znački (v nadaljevanju PBZ), ki je bila izvedena z orodjem 1KA. Vprašalnik je bil za izpolnjevanje odprt od 6. 6. 2018 do 29. 6. 2018 (zadnji vnos je bil 24. 6. 2018). ${ }^{4}$

Opis postopka zbiranja podatkov: Vprašalnik je v uvodnem delu vseboval splošne podatke o vrtcu ter skrbniku BZ in 7 vsebinskih vprašanj odprtega in zaprtega tipa. Povezava do vprašalnika je bila poslana po elektronski pošti s strani Društva Bralna značka Slovenije - ZPMS na vse slovenske vrtce (vprašalnik je bil namenjen institucijam kot celoti), in sicer na njihove elektronske naslove, ki so javno objavljeni na spletni strani MIZŠ - teh je bilo na dan pošiljanja (6. 6. 2018) $428,{ }^{5}$ gre torej za namenski neslučajnostni vzorec.

Od 428 slovenskih vrtcev se je vsaj deloma, s klikom na nagovor, odzvala dobra polovica vrtcev, to je 246 institucij (57 \% vprašanih). V 183 vrtcih so začeli izpolnjevati anketo (74 \% od tistih, ki so odprli stran z nagovorom), pogostost odgovorov pada od vnosa začetnih podatkov (158 izpolnjenih) do zadnjega vprašanja. $\mathrm{Na}$ anketna vprašanja je v celoti odgovorilo 69 ustanov (28 \% začetih anket), 74 jih je odgovorilo delno, skupaj je ustreznih 143 anket, kar je $58 \%$ začetih anket oz. $33 \%$ vseh slovenskih vrtcev. ${ }^{6}$

\section{Rezultati}

Soglasje za zbiranje osebnih podatkov v anketi: $\mathrm{n}=141 ; 45$ (32 \%) reševalcev ankete se ni strinjalo z zbiranjem osebnih podatkov, 96 (67\%) se je z zbiranjem podatkov strinjalo. Poudariti je treba, da gre za osebne kontakte zaposlenih oseb, ki bi želeli prejemati gradivo BZ ali pa so koordinatorji BZ ali drugih projektov, povezanih z branjem. Sledila so splošna vprašanja: uradni naziv vrtca, naslov, elektronski naslov; ime koordinatorja BZ, če ta obstaja (navedenih je 66 koordinatorjev), in elektronski naslov mentorjev branja (naslov je dalo 118 mentoric). Pri vprašanju, ali gre za samostojni vrtec ali vrtec pri osnovni šoli, je odgovarjalo 75 vrtcev, od tega jih je 29 (39\%) samostojnih in $46(61 \%)$ vrtcev pri OŠ.

Na vprašanje, ali v vrtcu izvajajo Bralno značko, je odgovorilo 75 anketiranih vrtcev (to je $52 \%$ vseh, ki so začeli z izpolnjevanjem ankete): 37 vrtcev jo izvaja pod tem imenom; 27 vrtcev jo izvaja, a pod drugim imenom. 7 vrtcev navaja, da

\footnotetext{
${ }^{4}$ Vprašalnik je pripravila Dragica Haramija, pregledala ga je Tilka Jamnik, skrbnik spletnega vprašalnika je bilo Društvo Bralna značka Slovenije - ZPMS.

${ }^{5}$ Po podatkih MIZŠ (2018) je število vseh javnih samostojnih vrtcev 108; število javnih vrtcev pri OŠ 227; število zasebnih vrtcev 93.

${ }^{6}$ Neustrezne so bile 103 ankete, in sicer: 5 anket je bilo v celoti praznih, 10 delno praznih, pri 25 je bil zabeležen klik na anketo, pri 63 klik na nagovor.
} 
izvajajo drugačne dejavnosti za spodbujanje družinskega branja, pri vsem navedenem pa lahko ugotovimo, da izvajajo dejavnosti Predšolske bralne značke. ${ }^{7}$ Od 75 prejetih odgovorov, torej kar 74 (99 \%) vrtcev, izvaja spodbude za družinsko branje.

Tabela 1: Izvajanje bralne značke $\mathrm{v}$ vrtcih ${ }^{89}$

\begin{tabular}{|l|c|c|}
\hline Ali v vašem vrtcu izvajate predšolsko Bralno značko? \\
\hline Odgovori & Frekvenca & Veljavni \\
\hline 1 Da. & 37 & $49 \%$ \\
\hline 2 Da, a jo poimenujemo drugače. ${ }^{8}$ & 27 & $36 \%$ \\
\hline $\begin{array}{l}3 \text { Ne, izvajamo drugačne dejavnosti za spodbujanje družinskega branja. } \\
\text { (Opišite.) }\end{array}$ & 7 & $9 \%$ \\
\hline 4 Ne izvajamo dodatnih dejavnosti za spodbujanje družinskega branja. & 0 & $0 \%$ \\
\hline 5 Drugo ${ }^{9}$ & 4 & $5 \%$ \\
\hline Skupaj & $\mathbf{7 5}$ & $\mathbf{1 0 0} \%$ \\
\hline
\end{tabular}

Očitno se v vrtcih zavedajo, da sta bralna pismenost in družinsko branje pomembna, ker v nobenem vrtcu niso podali odgovora, da ne izvajajo dodatnih dejavnosti za spodbujanje branja.

Naslednji vprašanji se navezujeta na način priprave in izvedbe bralnih dejavnosti $v$ vrtcu. Na vprašanje o načinu priprave bralnih gradiv je odgovarjalo 73 vprašanih. $V$ večini vrtcev imajo organizirano spodbudo družinskega branja na način, da otroci (z nahrbtnikom, vrečko, kovčkom) nesejo domov vnaprej pripravljene knjige; skupine imajo določen časovni interval vračanja (en teden, dva tedna). Drugi najpogostejši odgovor je bil, da seznamov nimajo (otrok s starši poljubno izbira dela, o katerih bo poročal).

\footnotetext{
${ }^{7}$ Te dejavnosti so (vsaka dejavnost je navedena enkrat): Bralni nahrbtnik Mavrična ribica; Bralni nahrbtnik: literatura za otroke (prvo in drugo starostno obdobje) in starše (strokovna literatura); interni knjižni projekt Skrivnostne torbice: izbrano gradivo potuje med vrtcem in domom, otroci in starši berejo, otroci o tem pripovedujejo v vrtcu, izdelajo izdelek na temo določene knjige, pripravijo razstavo, pripravijo kulturno prireditev na ravni vrtca na temo določene knjige - vsi oddelki berejo enako zgodbo, vendar prilagojeno starosti (v šolskem letu 2017/2018: Rdeča kapica); Malček bralček, izposoja knjig na dom enkrat tedensko 10 mesecev; Cicibralček; vsaka skupina si je izdelala svoj načrt po elementih PSP.

${ }^{8} \mathrm{Da}$, a jo poimenujemo drugače (navedba po pogostosti pojavljanja imena): 5-krat Palček bralček; 3-krat Bralni nahrbtnik; 2-krat Ciciuhec, Cici bralna značka; 1-krat Cicibralec, Bralna košarica, Palček bralček, Mali Savinjčani berejo, Pravljična mavrica, Pravljični palček, Mavrična ribica, Malček bralček, Ostržkova bralna značka, Bralni angelček, Zalko bere, Miškolinčkov nahrbtnik, Bralček, Predšolska bralna značka Petra Nosa, Bralni kovček, Bralni ježek, Eko bralni nahrbtnik, Predbralna značka Veronikin zaklad.

${ }^{9}$ Pod drugo so bili 4 odgovori, in sicer 3 od teh sodijo pod dejavnosti BZ (Potujoči knjižni nahrbtnik; drugi vrtec izvaja Ciciuhca, Slomškovo bralno priznanje, Knjižni nahrbtnik za vse starosti, imajo vrtčevsko knjižnico - vse knjige so vnesene v Cobiss in si jih starši lahko sposodijo; tretji vrtec navaja lutko Mijo, s katero spodbujajo različne bralne dejavnosti); en vrtec navaja, da izvajajo veliko bralnih dejavnosti v okviru programa, starše spodbujajo za branje otrokom doma (ni navedenih konkretnih dejavnosti).
} 
Tabela 2: Način priprave spodbujanja družinskega branja ${ }^{10}$

\begin{tabular}{|l|c|c|}
\hline \multirow{2}{*}{ Seznam(i) knjig za predšolsko Bralno značko (tudi, če jo poimenujete drugače) } \\
\hline \multirow{2}{*}{ Podvprašanja } & \multicolumn{2}{|c|}{ Enote } \\
\cline { 2 - 3 } & Št. odgovorov & Odstotki \\
\hline $\begin{array}{l}\text { V vrtcu pripravimo knjige (v bralni nahrbtnik, bralni kovček ...), } \\
\text { ki jih odnese otrok domov. }\end{array}$ & 33 & $45 \%$ \\
\hline Seznam(e) knjig po starostnih stopnjah pripravimo v vrtcu. & 23 & $32 \%$ \\
\hline Seznam(e) pripravijo v šolski knjižnici. & 7 & $10 \%$ \\
\hline Seznam(e) pripravijo v splošni knjižnici. & 6 & $8 \%$ \\
\hline Seznam(i) obsega(jo) približno ... knjig. (Navedite št. knjig.) & 10 & $14 \%$ \\
\hline $\begin{array}{l}\text { Seznama nimamo, otrok s starši poljubno izbira dela, o katerih } \\
\text { »poroča«. }\end{array}$ & 31 & $42 \%$ \\
\hline Drugo ${ }^{10}$ & 10 & $14 \%$ \\
\hline
\end{tabular}

Vrtci (ne glede na to, ali dejavnost poimenujejo PBZ ali ne) uporabljajo tri načine (ker je bilo možnih več odgovorov, so ti navedeni po pogostosti): najbolj množična varianta so bralni seznami, ti obsegajo od 20 do 35 knjig (pripravijo jih vzgojitelji, šolski ali splošni knjižničarji), izmed katerih starši in otroci izbirajo dela (50 \% od 73 odgovorov); na drugem mestu je bralni nahrbtnik (kovček, vrečka), v katerega mentorji branja pripravijo od 2 do 8 knjig, odvisno od starosti otrok (45\% od 73 odgovorov); tretja varianta je prosta izbira knjig za poročanje (takšnih je $42 \%$ odgovorov). Predvidevamo, da se odgovori podvajajo predvsem pri prvi in drugi varianti (seznam, nahrbtnik), ker si mentorji branja tudi za nahrbtnik pripravijo seznam (sami, s pomočjo knjižničarja). Povprečje o poročanih knjigah je odvisno od starosti otrok, in sicer od 1 do 6 knjig na otroka.

Pri vprašanju o načinih preverjanja prebranega je bilo podanih 68 odgovorov, ki jih lahko družimo po podobnosti (možnih je bilo več metod v enem odgovoru, saj je šlo za vprašanje odprtega tipa); odgovori so navedeni po frekvenci pojavljanja:

- najpogosteje otrok pripoveduje vsebino prebrane zgodbe (govorni nastop) drugim otrokom (v nekaterih vrtcih $\mathrm{v}$ jutranjem krogu, $\mathrm{v}$ bralnem kotičku, na pravljičnem stolu, na svetlobni kocki) ali individualno vzgojiteljici,

- mlajši otroci o prebranem kažejo ob slikanici, povedo posamezne besede ali besedne zveze,

- otrok pripoveduje zgodbo ob knjižnih ilustracijah,

- otrok ilustrira prizor iz prebranega literarnega dela (en vrtec navaja, da imajo mape za risbe, nastale po prizorih iz literarnih del),

- izpolnijo delovni list (narišejo vsebino/si izmislijo in ilustrirajo uganko ali izštevanko ...),

${ }^{10}$ Pod drugo so v vrtcih navajali sledeče: 3-krat: seznam knjig na spletni strani BZ; 2-krat: otrok si v priročni knjižnici sam izbere knjigo, ki si jo bo izposodil; 1-krat: nekateri oddelki pripravijo sezname oz. bralne nahrbtnike, drugi pustijo staršem in otrokom, da sami izberejo literaturo; v rubriko so navajali tudi odgovore, ki sodijo v eno od ponujenih možnosti (npr. priporočila knjižničarja, bralni seznami). 
- starši v zvezek napišejo otrokov odziv na prebrano delo, otrok zapis dopolni z ilustracijo, nalepijo fotografijo ipd.,

- otroci s starši pripravijo dejavnost na temo knjige,

- v skupini ustvarjajo lastne zgodbe,

- otrok zapoje pesem,

- otroci uprizorijo prebrano,

- v vrtcu skupaj s starši preberejo delo, nato imajo dejavnosti,

- otrok pripoveduje zgodbo ob lastnih ilustracijah,

- nekateri otroci prinesejo izdelane izdelke (lutke, risbe, napisane zgodbe, pesmi),

- otrok pripravi plakat, ob katerem pripoveduje o prebranem literarnem delu,

- otrok, ki predstavlja delo, na koncu postavlja vprašanja drugim otrokom v skupini (vsaj 3 vprašanja), tako skupno obnovijo zgodbo, izpostavljeni otrok pa je ponosen, ker ve, da so ga otroci poslušali; cela skupina pazljivo posluša, ker vedo, da bodo lahko »vprašani«.

V nekaj primerih se je v odgovorih pojavil tudi čas, ki ga namenijo navedenim dejavnostim, najpogosteje zjutraj ali pred spanjem; pogosto otroci pripovedujejo ob ponedeljkih ali petkih, ko prinesejo nazaj bralni nahrbtnik. V dveh primerih so bile navedene tudi drobne nagrade, ki si jih otroci pridobijo ob uspešno predstavljenem delu (nalepko na barvni papir; na pripravljene podlage lepijo simbole, npr. ribico, gumbek, sovico ..., s čimer označijo svoj napredek ter načrtujejo nadaljnje branje). V sedmih primerih vzgojiteljice (mentorice branja) poročajo, da v bralni nahrbtnik dodajajo tudi strokovne knjige za starše.

Naslednje vprašanje je povezano z izvajanjem PBZ v vrtcu v preteklem šolskem letu (2017/2018); spraševali smo po številu oddelkov v vrtcu, številu sodelujočih oddelkov in mentorjev ter povprečnem številu prebranih knjig na otroka.

Tabela 3: Podatki o branju za BZ v vašem vrtcu za šolsko leto 2017/2018 $(\mathrm{n}=20)$

\begin{tabular}{|l|c|c|c|c|c|c|}
\hline Oddelek & 1-2 leta & $\mathbf{2 - 3}$ leta & $\mathbf{3 - 4}$ leta & $\mathbf{4 - 5}$ let & $\mathbf{5 - 6}$ let & $\begin{array}{c}\text { Kombini- } \\
\text { rani od- } \\
\text { delki }\end{array}$ \\
\hline Št. vseh oddelkov & 32 & 44 & 34 & 44 & 44 & 20 \\
\hline $\begin{array}{l}\text { Śt. oddelkov, ki } \\
\text { sodelujejo pri bz }\end{array}$ & 28 & 41 & 32 & 42 & 38 & 20 \\
\hline Št. mentorjev bz & 52 & 79 & 68 & 69 & 65 & 36 \\
\hline $\begin{array}{l}\text { Śt. otrok, ki } \\
\text { sodelujejo pri bz }\end{array}$ & 361 & 539 & 632 & 849 & 858 & 320 \\
\hline $\begin{array}{l}\text { Povprečno št. } \\
\text { prebranih knjig na } \\
\text { otroka }\end{array}$ & $\begin{array}{c}2,53 \\
\text { (največkrat } \\
2 \text { knjigi, } \\
\text { sledijo 3; } \\
\text { razpon od } \\
1 \text { do 5) }\end{array}$ & $\begin{array}{c}2,64 \\
\text { (največkrat } \\
\text { razpon od } \\
1 \text { do 7) }\end{array}$ & $\begin{array}{c}3,73 \\
\text { (največkrat } \\
3 \text { knjige, } \\
\text { sledi 5 } \\
\text { knjig; } \\
\text { razpon od } \\
\text { 1 do 7) }\end{array}$ & $\begin{array}{c}4,10 \\
\text { (največkrat } \\
5 \text { knjig, } \\
\text { sledijo 3 } \\
\text { knjige; } \\
\text { razpon od } \\
1 \text { do 8) }\end{array}$ & $\begin{array}{c}4,41 \\
\text { (največkrat } \\
5 \text { knjig, } \\
\text { sledijo 3 } \\
\text { knjige; } \\
\text { razpon od } \\
1 \text { do 8) }\end{array}$ & $\begin{array}{c}3,45 \\
\text { (največkrat } \\
5 \text { knjig, } \\
\text { sledijo 3 } \\
\text { knjige; } \\
\text { razpon od } \\
1 \text { do 5) }\end{array}$ \\
\hline
\end{tabular}

$\mathrm{Na}$ to vprašanje je odgovorilo le od 20 do 38 vrtcev, torej tisti, ki so se v začetku izrekli, da sodelujejo pri Predšolski bralni znački, vendar so nekateri odgovarjali 
le za svojo skupino, ne za celoten vrtec; vprašanje zahteva vnaprejšnjo pripravo podatkov, zato predvidevamo, da so nekateri anketiranci na tem mestu prenehali z anketo, ker niso imeli zbranih podatkov. Pri (ročnem) pregledu posameznih vnosov je razvidno, da nekateri vrtci nimajo vseh starostnih skupin ali nimajo kombiniranih oddelkov ali pa so pisali podatke zgolj za eno skupino. To je bil razlog, da smo pri tem vprašanju izločili vse nepopolne ankete in z ročnim pregledom 20 popolnih in ustreznih anket za to vprašanje, prikazali odgovore v spodnji tabeli. Po pričakovanju je največ oddelkov, ki sodelujejo v BZ, z otroki, starimi od 4 do 5 in od 5 do 6 let. Kljub velikemu številu neuporabnih odgovorov se pokaže, da s starostjo otrok narašča vključenost v PBZ in minimalno število prebranih knjig za PBZ.

Najbolj uspešni programi za spodbujanje branja v vrtcu (na vprašanje odprtega tipa je odgovorilo 55 vprašanih, družili smo podobne odgovore in jih rangirali od najpogostejšega do najmanj pogostega v okviru posameznega skupnega izhodišča a, b, c, č; možnih je bilo več odgovorov):

a) Otroci nesejo knjige iz vrtca in jih imajo nekaj časa doma (od enega tedna do štirinajst dni):

- bralni nahrbtnik,

- bralni nahrbtnik z bralnim dnevnikom,

- knjižni nahrbtnik z lutko,

- pravljični potujoči kovček,

- bralna vrečka.

V tej skupini bralnih spodbud so pogosti bralni dnevniki (velikokrat se omenjajo skupaj z nahrbtniki, kovčki, vrečkami). Bralni zvezek, ki je namenjen opisu prebranega (zapisujejo starši) ter ilustriranju otrok ali prilaganju fotografij, povezanih z bralnim dogodkom pri otroku doma. V nekaj primerih je izpostavljena skupinska ustvarjalnost otrok, ki (skupaj s starši) nadaljujejo pisanje izvirne zgodbe (vsak otrok, ki prinese domov bralni zvezek, nadaljuje zgodbo tam, kjer je predhodni vrstnik končal). ${ }^{11}$ Enkrat je bila omenjena dejavnost, da pridejo starši v vrtec prebrat otrokovo najljubše literarno ali informativno delo. $\mathrm{V}$ enem vrtcu poročajo, da imajo pravljični dan, takrat otroci prinesejo knjigo od doma in jo preberejo v vrtcu. Omenjena je Cici vesela šola (stalna rubrika igrivega učenja v otroškem revijalnem tisku Cicido in Ciciban). V nekaterih vrtcih beležijo otrokov napredek na način dodajanja znakov za količino prebranega gradiva (npr. bralni vlakec, izdelava plakata z znaki otroka in dodajanje nalepk ob prebrani vsebini); iz enega vrtca poročajo, da ima vsak otrok svoj lonček s pikami; na pike vzgojiteljice napišejo avtorja in naslov literarnega dela, o katerem je otrok poročal, v lonček pa dobi barvico. Otrok v lonček nabere barvice različnih barv; ob koncu šolskega leta naredijo slavnostno podelitev lončkov z barvicami, ob katerem je tudi prijazen in pohvalni zapis, ki si ga

${ }^{11}$ Npr. v najstarejši skupini so izvajali izmišljanje lastne pravljice. Vsak teden je mapa potovala na domove, spremljal jo je medvedek Brundo. Otroci so skupaj s starši zapisali svoj del zgodbe. Otrok, ki je prinesel mapo nazaj v vrtec, je pripovedoval, kaj so doživeli doma z Brundom in kdo jim je pri tem pomagal. Vsak teden so prebrali nadaljevanje zgodbe in tako spodbujali k razmišljanju o morebitnem nadaljevanju. Na koncu šolskega leta so zgodbo izdali v knjižni obliki, ki jo je vsak otrok odnesel domov; otroci so bili močno motivirani in težko so čakali, kdaj bodo prišli na vrsto. 
lahko otrok zalepi v bralni zvezek. Poleg tega vedno po opravljeni dejavnosti dobi sporočilno pisemce, ki ga s starši prebere in zalepi v zvezek, zvezek pa gre $\mathrm{z}$ otrokom v prvi razred.

b) Izposoja knjig v šolski ali vrtčevski knjižnici; spodbujanje mentorjev k obisku otrok in staršev v splošni knjižnici in spodbujanje staršev, da otroka vpišejo v splošno knjižnico. V enem vrtcu poudarjajo, da je zelo dobro sprejeta dejavnost pravljične minute s knjižničarko: obiski knjižničarke v igralnicah in obiski krajevne knjižnice ter pravljične sobe.

c) Posebne aktivnosti (na posebnih lokacijah) v popoldanskem času (starši in otroci skupaj), pravljične ure (v vrtcu ali knjižnici; dopoldan ali popoldan):

- branje pod krošnjami,

- starši sami pripravijo dejavnosti za otroke,

- nadaljujejo s projektom $\mathrm{V}$ objemu besed,

- noč knjige (23. april) ali večer ob 2. aprilu, mednarodnem dnevu knjig za otroke,

- literarna čajanka,

- ob praznovanjih (rojstni dan, veseli december),

- kulturni teden v vrtcu.

Iz enega od vrtcev pišejo, da imajo pravljično sobo, ki je odprta ves dan. Starši jo lahko z otrokom obiščejo zjutraj pred vstopom v skupino ali popoldne, ko otrok že zapusti skupino (starši tako nekaj časa preživijo skupaj z otrokom v pravljični sobi ob pregledovanju knjig).

č) Povezovanje književnosti z drugimi umetnostmi:

- razstava kakovostnih slikanic v vrtcu,

- razstava otroških ilustracij, ki nastanejo na podlagi prebranih del,

- uprizoritvene dejavnosti otrok (lutkovne in dramske predstave),

- vključevanje petih pesmi in deklamiranja na različnih prireditvah v vrtcu in pri delu v skupini.

Navedena so tudi predavanja in delavnice o pomenu družinskega branja za starše (tematski roditeljski sestanki, govorilne ure), povabilo k sodelovanju v $\mathrm{PBZ}^{12}$ in/ali drugih dejavnostih, povezanih z družinskim branjem, pogovori staršev na sestankih, kjer med seboj izmenjujejo dobre prakse. Omenjeno je tudi srečevanje staršev (tudi starih staršev), otrok in vzgojiteljev (mentorjev branja) v popoldanskem času, pri čemer gre za usmerjene bralne dejavnosti, pogovore o prebranem in izvedbo dejavnosti, ki se navezujejo na prebrane (leposlovne ali/in informativne) vsebine. Enkrat je omenjeno tudi branje $\mathrm{v}$ različnih jezikih in posebna skrb za razvijanje pripovedovalne sheme.

Pogosto so omenjeni knjižni kotički v igralnicah, izražena je skrb vzgojiteljev za kakovostna gradiva (nekateri navajajo, da si lahko otroci na dom izposodijo tudi knjige, ki so v knjižnem kotičku in so otrokom všeč).

Spodbujanje družinskega branja poteka tudi tako, da vzgojiteljice (mentorice branja) v bralne nahrbtnike (vrečke, kovčke) dodajajo informativno literaturo za

${ }^{12}$ Omenjeno je tudi razdeljevanje zloženke Otrok, branje, odrasli, ki jo izdaja Društvo Bralna značka Slovenije - ZPMS za promocijo PBZ. 
starše, jim po elektronski pošti pošiljajo strokovne članke. Iz enega vrtca poročajo, da branje spodbujajo tudi s priznanji odraslim (staršem, starim staršem, sorodnikom, starejšim sorojencem ...), ki otrokom berejo. Starši ob začetku šolskega leta pogosto prejmejo pisni nagovor za spodbujanje vključevanja v bralne aktivnosti, ki jih organizira vrtec.

V odgovorih je navedenih tudi nekaj projektov, ki so potekali ali še potekajo v vrtcih: Rastoča knjiga (en vrtec), V objemu besed (2016-2017), OBJEM (20162022: sodelujeta dva vrtca, ki sta izpolnjevala anketo).

V predzadnjem vprašanju so vzgojitelji - mentorji branja beležili pričakovanja, in sicer kaj pričakujejo od Društva Bralna značka Slovenije - ZPMS v smislu podpore pri svojem delu. Na to vprašanje je odgovorilo 49 vprašanih (ker gre za vprašanje odprtega tipa, smo odgovore družili po pogostosti v dve skupini):

a) Pričakovanja, povezani s potrebami mentorjev pri delu:

- podpora z didaktičnimi sredstvi, nabor dejavnosti za spodbujanje družinskega branja,

- spodbuda pri izbiri kakovostnih literarnih del,

- priporočilni seznami primernih knjig (seznam novosti),

- strokovna podpora mentorjem, izvedba vzorčne ure,

- večja mera koordinacije med vrtci,

- brezplačna gradiva za starše, ki spodbujajo branje,

- smernice za dobro spodbujanje, praktične predstavitve za starše,

- pomoč pri uvodni in zaključni prireditvi,

- daljši rok izposoje knjižnih gradiv za vzgojiteljice,

- pohvala za celotno skupino, ki sodeluje,

- vključevanje vrtcev v uspešne projekte.

b) Pričakovanja, ki so povezana s finančnimi sredstvi:

- ugodno ceno ali brezplačna predavanja za mentorje branja,

- sofinanciranje obiskov znanih pisateljev in pesnikov,

- (za vrtce brezplačne) izvedbe bralnih uric, pravljičnih dogodkov, pripovedovanja zgodb,

- motivacijska gradiva, zanimive nagrade, brezplačna priznanja za otroke ali darilne knjige,

- plakete.

En odgovor je bil, da ne želijo sodelovati z BZ, ker priznanja niso všečna in je njihova cena visoka, v enem vrtcu Društva Bralna značka Slovenije - ZPMS ne poznajo dovolj dobro, zato ne morejo izraziti svojih pričakovanj, v nekaj vrtcih so napisali pohvalo delovanju društva.

Zadnje vprašanje je mentorje branja spodbujalo, naj zapišejo, če želijo kaj sporočiti. Tudi to je bilo vprašanje odprtega tipa, nanj je odgovorilo le 22 vprašanih vrtcev, zato smo smiselno družili podobne navedbe. Želijo si:

- sezname priporočene literature po starostnih stopnjah, nekateri s konkretnimi naslovi kakovostne literature po starosti otrok $(1-2,2-3 \ldots)$,

- obveščanje o novejših kakovostnih knjigah,

- obveščanje o dogodkih, povezanih s PBZ, 
- da bi BZ mentorjem omogočila izmenjavo dobrih praks,

- da bi BZ mentorjem omogočila izobraževanja, povezana s PBZ.

\section{Sklep}

Bralna značka za predšolske otroke je namenjena predvsem družinskemu branju in ustvarjanju spodbudnega okolja za otrokov stik s knjigo. Seznam priporočenih del je namenjen smernicam, kako otroku, ki še ne bere sam in torej nujno potrebuje posrednika, pomagati vstopiti v svet knjig. V zadnjem desetletju je skokovito naraščala (a v zadnjih treh letih nekoliko upadla) produkcija otroških in mladinskih literarnih del, pri čemer pa število kakovostnih knjig ni naraščalo sorazmerno. Prav zato je dela treba vrednotiti in otrokom ponuditi najboljše, saj v institucionalno književno vzgojo sodi kakovostna literatura. Didaktiki slovenščine se strinjajo, da je od najzgodnejšega otroštva nujno razvijati otrokove recepcijske strategije (prim. Kordigel Aberšek 2008, Krakar Vogel 2016, Saksida 2017). Poudarjena je ključna vloga pedagoškega delavca $\mathrm{v}$ procesu branja, pri čemer bralni dogodek poteka $\mathrm{v}$ vrtcu »pri pogovoru v vrtčevski skupini in šolskem pouku (podrobna skupna analiza posameznih krajših besedil, npr. pesmi, odlomkov iz pripovedi, tudi krajših celovitih besedil, npr. slikanic); različnih oblikah vodenega spodbujanja branja daljših celovitih besedil (družinsko in domače branje, priznanje za bralno značko, Cankarjevo tekmovanje ipd.) « (Saksida 2017: 48). Seznami kakovostnih knjig za posamezno starostno obdobje so odlično izhodišče za spodbujanje družinskega branja, kar je potrdila tudi anketa. Seznam naj bo dovolj široko zastavljen, da bo zajel vse bralne okuse, priporočamo od dvajset do trideset naslovov za posamezno skupino (kar v večini vrtcev, ki so odgovarjali, že prakticirajo). To se zdi obvladljivo tudi za profesionalnega posrednika (vzgojitelja - mentorja branja), ki PBZ vodi. Tako lahko dobro pozna izbrane knjige, ki jih otroci predstavljajo, starši in otroci pa imajo možnost s seznama izbirati dela po lastni presoji (in ne nazadnje glede na dostopnost gradiva).

Ob pripravi bralnih seznamov za družinsko branje bi bilo treba upoštevati različne kriterije. Zelo pomembna je starost naslovnika (otroka) in njegov kognitivni razvoj, ki narekuje zanimanje za določeno temo: otroke seznanjamo z leposlovnimi in informativnimi (poučnimi) vsebinami. Prav tako ni zanemarljiva dolžina besedila, saj gre pri branju v predšolskem obdobju predvsem za postopno razvijanje zmožnosti poslušanja. Pri leposlovnih delih ne bi smeli pozabiti na literarni kánon. Med novejšimi literarnimi besedili bi veljalo izbirati predvsem po tematskem principu, pri čemer je nujno ohranjati razmerje med izvirno slovensko in prevedeno literaturo, poudarek naj bo na izvirnem leposlovju. Skozi književna dela in ob literarnih junakih otrok spoznava širši kulturni kontekst nacionalne književnosti in drugih književnosti. Ob informativnih (poučnih) knjigah bo otrok spoznal, da je pridobivanje znanja lahko zabavno in zanimivo.

\section{LITERATURA}

Mara COTIČ, 2011: Učenje in poučevanje različnih vrst pismenosti. Razvijanje različnih pismenosti. Ur. M. Cotič, V. Medved Udovič, S. Starc. Koper: Univerza na Primorskem, 
Znanstveno-raziskovalno središče, Univerzitetna založba Annalis (Knjižnica Annalis Ludus). 11-18.

Dragica HARAMIJA, Tina VRŠNIK PERŠE, 2017: Končno poročilo projekta V objemu besed. Dostop 7. 7. 2018 na: http://www.bralnaznacka.si/sl/projekt-v-objemu-besed/koncnoporocilo-projekta/.

Tjaša JUG, Polona VILAR, 2015: Focus group interview through storytelling: researching pre-school children's attitudes towards books and reading. Journal of Documentation 71/6. $1300-1316$.

Livija KNAFLIČ, 2002: Kako družinska pismenost vpliva na pismenost otrok. Psihološka obzorja 11/2, 37-52.

--, 2009: Priročniku na pot. Branje za znanje in branje za zabavo: priročnik za spodbujanje družinske pismenosti. Ur. L. Knaflič, N. Bucik. Ljubljana: Andragoški center Slovenije. 6.

Metka KORDIGEL ABERŠEK, 2008: Didaktika mladinske književnosti. Ljubljana: Zavod Republike Slovenije za šolstvo.

Boža KRAKAR VOGEL, 2016: Oblike kurikularnega branja literature. Otrok in knjiga $43 / 95,5-16$.

Lisa KROLAK, 2006: The Role of Libraries in the Creation of Literate Environments. Hamburg: UNESCO Institute for Education.

Ljubica MARJANOVIČ UMEK, Simona KRANJC, Urška FEKONJA, 2006: Otroški govor: razvoj in učenje. Domžale: Izolit.

Ljubica MARJANOVIČ UMEK, Kaja HACIN, Urška FEKONJA PEKLAJ, 2018: Zgodnja pismenost otrok: učinek vrtčevskih in družinskih dejavnikov. Sodobna pedagogika 69/1, 10-27.

Vida MEDVED UDOVIČ, 2011: Večrazsežna pismenost izziv sedanjosti. Razvijanje različnih pismenosti. Ur. M. Cotič, V. Medved Udovič, S. Starc. Koper: Univerza na Primorskem, Znanstveno-raziskovalno središče, Univerzitetna založba Annalis (Knjižnica Annalis Ludus). 37-45.

Ministrstvo za izobraževanje, znanost in šport, 2017: Nacionalna strategija za razvoj bralne pismenosti (predlog). Dostop 7. 7. 2018 na: http://www.mizs.gov.si/fileadmin/mizs.gov.si/ pageuploads/novice/doc/Bralna_Pismenost_javna_razprava_april_2017.doc.

Ministrstvo za izobraževanje, znanost in šport, 2018: Seznam vrtcev. Evidenca zavodov in programov. Dostop 5. 7. 2018 na: https://paka3.mss.edus.si/registriweb/SeznamVrtci.aspx.

Sonja PEČJAK, Ana GRADIŠAR, 2015: Bralne učne strategije. Ljubljana: Zavod Republike Slovenije za šolstvo.

Igor SAKSIDA, 2017: Bralni dogodek v vrtcu. V objemu besed: razvijanje družinske pismenosti. Ur. D. Haramija. Maribor: Univerzitetna založba Univerze v Mariboru, Pedagoška fakulteta. $47-54$.

Amalija ŽAKELJ, Milena IVANUŠ GRMEK, 2011: Rezultati učencev pri nacionalnem preverjanju znanja in socialno-kulturno okolje. Pedagoška obzorja 26/4, 3-17.

\section{ENCOURAGING FAMILY LITERACY IN CHILD'S PRE-SCHOOL PERIOD: THE PRE-SCHOOL READING BADGE}

The paper provides basic starting points for the development of family literacy relating to institutional incentives (kindergartens and libraries) that implement the Reading Badge for pre-school children or other projects related to family literacy. In June 2018, a survey was carried out in all kindergartens in Slovenia. The questionnaire was primarily based on the 
ways to promote family reading, methods of working with children, the choice of materials and the verification of the material read. The results show that educators, i. e. kindergarten teachers, promote family reading through a variety of reading projects, and, in particular, by supporting family literacy, they create a stimulating environment for children's contact with books. The questionnaire analysis shows that the kindergarten teachers (reading mentors) need and wish for recommended reading lists to follow the guidelines of how to help a child who is not yet an independent reader and therefore necessarily needs an intermediary to help him/her to enter the world of reading. In the last decade, the production of children's and youth literary works has risen sharply (and in the last three years it has reduced slightly), nevertheless, the quantity of quality books has not been increasing proportionally.

Therefore, literary work needs to be evaluated, only the best should be offered to children, and only quality literary work can form the institutional literary education. For promoting family literacy, quality books reading lists for particular age ranges are an excellent starting point (for example, twenty to thirty titles for each age range).

Various criteria should be taken into account when preparing readers for family reading:

- The age of the addressee (child) and his cognitive development, both forming an interest in a particular topic, are very important: children should be acquainted with the literary and informative (educational) content.

- Furthermore, the length of the text is not negligible, since the primary purpose of reading in the pre-school period is to gradually develop the listening ability.

- In literary works, the literary canon should be taken into consideration.

- Among the more recent literary texts, one should choose mainly by the thematic principle, taking into consideration the balanced ratio between the original Slovene and the translated literature, with the emphasis on the original literature. Through literary works and literary heroes, a child becomes aware of the wider cultural context of national and other literatures. Using informative (educational) books, a child will be properly introduced to the fact that acquiring knowledge can be fun and interesting. 


\title{
Kulturistike - kulturološka branja beletristike
}

\author{
PRIMOŽ MLAČNIK \\ Fakulteta za družbene vede, Kardeljeva ploščad 5, \\ SI-1000 Ljubljana, primoz.mlacnik@fdv.uni-lj.si
}

\begin{abstract}
Članek obravnava filozofsko-teoretske tokove, ki so prispevali h kulturološkemu obratu v literarni vedi v devetdesetih letih dvajsetega stoletja. V okviru trodelne raziskovalne sheme (kontekst/avtor, tekst/literarno delo, občinstvo/bralec), ki je skupna kulturološkim in sodobnim literarnoteoretskim branjem literature, analitično reflektiramo dela nekaterih ključnih avtorjev s področja poststrukturalizma, Frankfurtske šole kritične teorije, teorij ideologije in recepcijskih študij. Na ta način avtor predstavi načine, na katere so filozofsko-teoretski tokovi spremenili in nadgradili tradicionalno literarnoteoretsko pojmovanje spoznavne, etične in estetske razsežnosti literarnega dela. V zaključku so predstavljena njihova stičišča, razhajanja in omejitve.

The article draws on the philosophical-theoretical currents that contributed to culturological shifts in literary science during the last decade of the twentieth century. The work of key authors from the field of post-structuralism, the Frankfurt school of critical theory, and theories of ideology and reception studies is analytically reflected on the level of the tripartite research scheme (context/author, text/literary work, audience/reader) common to culturological and contemporary literary-theoretical readings of literature. In this way, we reveal how philosophical-theoretical currents have transformed and enhanced the traditional literarytheoretical conception of the cognitive, ethical and aesthetic dimensions of the literary work. In the conclusion, crossroads, divergences, and limitations in these methods are also presented.
\end{abstract}

Ključne besede: kulturologija, tradicionalna in sodobna literarna teorija, razsežnosti literarnega dela, literarno bistvo

Key words: culturology, traditional and contemporary literary theory, dimensions of literary work, literary essence

\section{Kulturološko-literarna afera}

Slovenski model kulturologije je matrica interdisciplinarnih teorij in pristopov, ki so jih slovenski raziskovalci kulturnih študij pred leti predstavili slovenskemu bralstvu v obsežnih in preglednih knjigah uvoda v kulturne študije Cooltura (Debeljak idr. 2002) in Politike popa (Stanković 2005). Številni avtorji obeh knjig so pestro tradicijo dopolnjujoče obravnavali skozi birminghamsko in frankfurtsko 
šolo kulturnih študij ter (post)strukturalizma. Kulturološki pristop h književnosti se epistemološko nanaša na »eklektičn/o/ zmes lingvistike, poetike, filozofije, sociologije, antropologije, psihoanalize, zgodovine in drugih ved«, ki jo Marko Juvan poimenuje enostavno s »teorija« (Juvan 2006: 41), kar pomeni, da kulturološki pristop ni niti enovit niti en sam in da je združljiv s sodobnimi literarnoteoretskimi pristopi.

Kulturne študije so se razvile kot kritičen odziv na elitistično tradicijo britanske literarne kritike 19. in 20. stoletja, ki je še vedno strogo ločevala med trivialno, t. i. množično kulturo, in elitno kulturo kot vsem estetskim in moralno najboljšim, kar proizvaja človeštvo (Juvan 2006: 24). V sodobnosti so se vrnile k svojim izvorom, kar so v preteklih petnajstih letih obravnavali nekateri slovenski raziskovalci (Grosman 2004, Juvan 2006, Potocco 2012, Virk 2007 in 2008). Čeprav je bila v dvajsetem stoletju paradigmatska izmenjava med kulturnimi študijami in literarno vedo do neke mere recipročna, se je sredi devetdesetih let pokazal »razbojniški« značaj kulturnih študij (Pužar 2010). ${ }^{1}$

Leta 1993 je Ameriška zveza za primerjalno književnost izdala Bernheimerjevo poročilo, v katerem je pozvala k spoju primerjalne književnosti in kulturnih študij. Po Virku (2007) se je takrat pričel kulturološki obrat v primerjalni književnosti, ki se je poleg kulturnih razpustila tudi na prevodne študije (Virk 2007: 27). Šlo je za odziv na "permanentno krizo literarne vede« (Juvan 2006: 15), ki se je zgodil v kontekstu naraščajoče kulturne, ideološke, rasne in spolne pluralizacije in hibridizacije ameriške družbe. K vzrokom, ki so ta obrat pogojevali, sodijo tudi: razvoj literarne teorije pod vplivom francoskega poststrukturalizma, upad prestiža besedne umetnosti, ki je postala le eden od načinov potrošnje časa in denarja ter konec velikih pripovedi, ki ni pomenil le odpora do urejenih in zaključenih literarnih pripovedi, ampak tudi legitimacijsko krizo znanja, ki so ga pričele obvladovati mednarodne institucionalne zahteve po njegovi uporabnosti in racionalizaciji, kar je literarno vedo postavilo v nehvaležen položaj (Juvan 2006: 27-54). Čeprav so slovenski raziskovalci opozarjali na nujnost literature in vrednost literarne vede (Juvan 2006: 51-54) ter zagovarjali njeno upravičenost kot samostojne discipline in kot posebnega raziskovalnega področja (Virk 2007: 37, 50), so hkrati pozivali k rekonstrukciji njenega znanstvenega in pedagoškega polja v skladu s kulturologijo (Juvan 2006: 18). Pokazali so, da so kulturološke metode tudi moderne metode literarne vede (Grosman 2004, Virk 2008, Potocco 2012). V nadaljevanju predstavljam nekaj segmentov kulturološko-literarnega metodološkega spoja in osvetljujem, kako le-ta nadgrajuje tradicionalno literarno teorijo.

\section{Kulturologija in tradicionalna literarna teorija}

Prva razlika med kulturološkim pristopom in tradicionalnim literarnoteoretskim pristopom h književnosti, ki jo obravnavam, je kategorija širine. Kulturološki

\footnotetext{
${ }^{1}$ Kulturne študije so »disciplinirana protidisciplina, /katere/ metodološka narava je piratska, /saj/ »krade« koncepte /in se povrh še/ avanturistično zabava, a obenem ostaja nevarna /.../, transformativna /.../, romantična /.../, pogumna /.../, kritična /.../, oportunistična /.../ in skupnostna /.../ (Pužar 2010: 196).
} 
pristop h književnosti je širši od pristopa literarne teorije, od katere se sicer lahko precej nauči, predvsem iz morfoloških in aksioloških razčlenitev literarnega dela, tj. prek poznavanja notranje in zunanje zgradbe besedila in sestavnih elementov oblike, snovi, stila, vsebine, tipologije besedne umetnosti, tem, motivov, tipologije bralcev ter načel vrednotenja v literarni vedi (Kos 1995: 18). To pomeni, da lahko kulturološki pristop vključuje metodološko-teoretske postopke in enote analize kot tudi spoznanja literarne teorije in ugotovitve literarne zgodovine, vendar pri vsem tem ne ostaja na ravni notranje in zunanje zgradbe besedila. Kulturološki pristop h književnosti naj bi upošteval temeljno načelo, ki so ga izpostavili Raymond Williams in drugi očetje britanskih kulturnih študij, da literarnih del ne moremo obravnavati ločeno od določene kulture, od družbenih in ekonomskih razmerij, v katerih so dela nastala (Stanković 2002: 19).

Če h književnosti pristopamo kulturološko, pomeni, da vse, s čimer se ukvarja literarna teorija, kontekstualiziramo; posamezno literarno delo obravnavamo celostno, s pojavi, ki ga pogojujejo in presegajo - od družbenoekonomskih razmerij, avtorjevega biografskega konteksta, prek pomena jezika v literarnem delu, do publikacije, distribucije in potrošnje knjige ter $\mathrm{v}$ najsplošnejšem, $\mathrm{z}$ načinom in $\mathrm{s}$ postopki samega branja kateregakoli literarnega dela in branja določenega literarnega dela. Medtem ko tradicionalna literarna teorija bistvo literarnega dela razčleni in strukturira navznoter (Kmecl 1995: 9-14, Kos 1995: 89-143), namreč po t. i. literarni globini in širini, ${ }^{2}$ kulturne študije to počnejo navzven, po prostorsko-časovni globini in širini. Tako skušajo izpostaviti družbeno-zgodovinske razsežnosti in kulturno zasnovo literarnega bistva, ki ni negibno - spreminja se v odnosu do prostora in časa ter glede na zorni kot, iz katerega ga opazujemo. Medtem ko lahko kulturološki pristop še vedno vključuje literarnoteoretske elemente, pa se mora glede na metodološka razhajanja med Birminghamom in Frankfurtom ${ }^{3}$ delno odpovedati dvojemu: predpostavki tradicionalne literarne teorije, da je naloga teoretikove hermenevtične prakse odkrivanje notranjega in prisotnega bistva literarnega dela ter vrednostnim sodbam literarnega dela, ki izhajajo iz tradicionalne literarne teorije.

${ }^{2}$ Literarna teorija jemlje dobršen del svojega konceptualnega in epistemološkega besednjaka iz metafizike (od Aristotela do Heideggerja) ter kot takšna daje prednost prisotnemu in bivajočemu (Kos 1995: 49), do katerega je v kritiki logocentrizma neizprosen Jacques Derrida (1998). To pomeni, da literarna teorija bistvo »išče« z razslojevanjem in razčlenjevanjem besedila, pri čemer zapostavlja nejezikovne dejavnike. Takšen primer je Kmeclova uvodna razprava o pomenu literarne teorije (Kmecl 1995: 9) in pa Kosova razprava o nemimetičnosti modernistične književnosti, $v$ kateri domnevno prevlada estetska nad spoznavno komponento (Kos 1995: 35).

${ }^{3}$ Avtorje obeh šol zaznamuje metodološka interdisciplinarnost in neenotnost paradigmatskih predpostavk. Oboji združujejo teoretsko in empirično raziskovanje, pri čemer avtorji britanskih kulturnih študij uporabljajo etnografske metode (holistično razumevanje kulturnih fenomenov), metode analize tekstov (razumevanje razmerij moči, ki so vpisana v pomene, ki jih generirajo besedila) in recepcijske študije (analiza tekstovnih pomenov, ki krožijo med občinstvom) (Barker 2000 v Stanković 2000: 61), avtorji Frankfurtske šole pa se opirajo predvsem na filozofijo (Heglovo dialektiko) in psihoanalizo (Debeljak 2002: 73). Zadnje lahko pomeni tudi to, da se bistvo besedila tvori prek nasprotij oziroma da so kritičnemu bralcu ob upoštevanju kategorije nezavednega dani zgolj manifestativni pomeni, ki prekrivajo latentne strukture. 
Kulturološki pristop ne more presojati književnosti z vidika tradicionalne literarne teorije, saj z vidika kulturnih študij ni niti kakovostnih niti nekakovostnih žanrov, ni dobre in slabe ter visoke in nizke literature. Kulturologi ne moremo ponavljati zgodovinskih napak britanskih konservativnih literarnih kritikov ${ }^{4}$ in razlikovati med elitno in popularno književnostjo. Tudi plehka, množična, trivialna, »neresna« književnost je kulturno posredovana književnost, ki je bogat vir reprezentacij kulturnih vzorcev, praks, identitet, idej in razmerij med različnimi družbenimi skupinami. Po drugi strani pa ni niti nujno niti mogoče, da bi se odpovedali kritičnemu branju in razsojanju. Splošen raziskovalni etos, na katerem temelji kulturološki pristop, je političen: daje glas izključenim, raziskuje in razume tisto, kar je spregledano in zapostavljeno, ter sprevrača zdravorazumske interpretacije kulturnih fenomenov. Izpostavlja razmerja, ki niso očitna.

V skladu s tradicionalno literarno teorijo se bistvo literarnega dela vzpostavlja v odnosu do različnih teoretskih in kritiških branj (Kos 1995: 25-48), pri čemer pa ni povsem jasno, ali bralec bistvo samo razbira glede na različne referenčne teoretske kode ali pa ga aktivno soustvarja. Literarno bistvo, ki je občasno zamenljivo z umetniško lepoto (Kos 1995: 41), je zasnovano skozi estetsko, spoznavno in etično razsežnost literarnega dela. Te tri sestavine so v literarni teoriji precej jasno opredeljene: nanašajo se na čutne, spoznavne in idejne učinke in razmerja literarnega dela. Vedeti moramo, da ne gre za nevtralne, ampak za kulturno pogojene razsežnosti, katerih pomen opredeljuje večinska in dominantna kultura. To pomeni, da bodo bralci z različnimi socialnimi, verskimi, etičnimi, razrednimi in rasnimi ozadji literarno bistvo interpretirali različno, torej še na veliko več načinov, kot bi lahko sklepali glede na Hallovo klasifikacijo treh tipov občinstva oziroma načinov branja (Stanković 2002: 38). ${ }^{5}$

Specifičen metodološko-raziskovalni okvir kulturološkega pristopa pa se razlikuje glede na to, ali kot analitiki in interpreti dajemo prednost estetski (čutnim občutkom in estetskim doživljajem lepega ob branju literarnega dela), spoznavni (prek literature spoznavamo stvarnost) ali etični razsežnosti literarnega dela (temu, kar vpliva na bralčevo vrednostno razmerje do sveta, na želje, težnje, namene) oziroma kaj je za kontekst, v katerega se umešča literarno delo, bistveno (Kos 1995: $27,30,35)$. V tem smislu je vsako kulturološko branje tudi partikularno in ne more biti povsem objektivno. Zato je toliko bolj pomembna refleksija lastne pozicije, ki ni nikoli dokončna. Kulturološki bralec se mora vnaprej odreči strinjanju o obstoju ene ultimativne resnice in odkrivanju notranjega bistva literarnega dela.

\footnotetext{
${ }^{4}$ Kulturne študije namreč izhajajo iz dediščine britanskih literarnih kritikov, ki so kot največje probleme moderne kulture in literature izpostavljali njuno duhovno obubožanost, dekadenco in banalnost (Stankovič 2002: 14).

${ }^{5}$ Klasifikacija Stuarta Halla temelji na predpostavki, da je značaj vsakega sporočila polisemičen in da je njegov pomen bolj kot od sporočevalca, ki pomen zakodira, odvisen od naslovnika, ki pomen odkodira. Po Hallu obstajajo trije prevladujoči načini odkodiranja oziroma branja tekstov. Če naslovnik razume sporočilo v skladu z referenčnim kodom proizvajalca sporočila, je branje dominantno-hegemonsko; če naslovnik dvomi o konsistentnosti proizvajalčevega koda, je branje pogajalsko; če pa naslovnik pomen sporočila odkodira glede na alternativen referenčni okvir, je branje opozicijsko (Turner 1996 v Stanković 2002: 38).
} 


\section{Filozofsko-teoretske osnove kulturnih študij in sodobne literarne vede}

Kulturološki pristop se od tradicionalne literarne teorije skratka razlikuje po tem, da literarna dela kontekstualizira, njihovo bistvo pojmuje na neesencialističen način ter zagovarja, da pomeni, ki jih literarna dela ustvarjajo, niso nikoli dokončni. Kulturološki pristopi k literaturi v preoblikovani shemi komunikacijskega modela avtor (kontekst) - delo (tekst) - občinstvo naslavljajo vse tri kategorije prek treh prevladujočih kvalitativnih metod: etnografska metoda celostno obravnava vse kulturne značilnosti okolja, iz katerega izhaja avtor; analiza tekstov, ki izhaja iz poststrukturalizma, se ukvarja z odnosom med pomeni in razmerji moči; recepcijske študije pa se ukvarjajo z množico različnih branj (Barker 2000 v Stanković 2002: 61). Enaka trodelna shema je skupna tudi modernim metodam literarne vede, s katerimi si kulturne študije delijo skupne filozofsko-teoretske tokove (Virk 2008: 8-9).

$\mathrm{Na}$ ravni analize pomenov literarnega dela si kulturologija in sodobne literarne vede delijo avtorje francoskega (post)strukturalizma, Lacanovo psihoanalizo in dekonstrucijo. S kontekstom se poleg sociološke, psihološke, biografske, psihoanalitične metode ukvarjajo teorije ideologije. V polju recepcijskih študij pa metode sodobnih literarnih ved dopolnjujejo filozofsko-teoretske tokove, ki si jih izposoja kulturološki pristop k literaturi. Oglejmo si nekaj primerov, ki skozi različne paradigmatske tradicije reflektirajo estetsko, spoznavno in etično razsežnost literarnega dela.

\subsection{Poststrukturalizem}

Delo francoskih poststrukturalistov je v kulturoloških pristopih še vedno pomembno za razumevanje neesencialnosti oziroma konstruktivnosti leposlovnih del, saj se ukvarja z zagatami, ki jih pred analitika postavljajo ločnice med modernistično in postmodernistično, žanrsko in nežanrsko ter manjšinsko in svetovno književnostjo. Glede na (post)strukturalistično misel so to namreč zgolj manifestativne ravni latentnih struktur, oblikovanih kot matrice temeljnih binarnih opozicij, ki pomena ne strukturirajo na vrednostno nevtralen način, temveč v skladu s prevladujočimi družbenimi vrednotami, praksami in razmerji moči.

Temeljno gonilo neesencialističnega pristopa k literaturi, ki je skupen kulturološkemu pristopu in sodobni literarni vedi, izhaja iz Nietzschejeve kritike metafizičnega pojmovanja izvora in resnice, ki je napajalo tudi teorijo Michela Foucaulta. Dekonstrukcija je »kritična metoda branja filozofskih in teoretskih besedil /Derridaja/, ki je /.../ omogočila, da v metafizičnem iskanju bistev razkrijemo nerazrešljiva protislovja« (Juvan 2006: 35). Derrida v svojem delu pokaže, da jezikovni pomen ni stalen; ne le, da nima izvora, ampak se tudi nenehno spreminja - medbesedilno in medčasovno. Po Derridaju se adornovsko vztrajanje v neidentiteti razkriva kot to, kar je, nič več in nič manj kot drža. Neidentiteta je po Derridaju votlo bistvo vsakega besedila, pred katerim se bralec znajde kot deželan iz Kafkove parabole Pred zakonom. Po Derridaju je namreč bistvo literarnega besedila to, da je nebistveno in kot Kafkov zakon neidentično samo s seboj. Zakon, ki deluje v književnosti, je zakon razlike, ki odlaga in prelaga pomen na druga besedila, s katerimi lahko bralec interpretira izvirnik. Neesencialnost pomena $\mathrm{v}$ besedilu pa vsebuje 
tudi druge implikacije, namreč da je potrebno vsako besedilo razumeti skupaj z nelingvističnimi dejavniki, kar avtorju sicer odvzame avtonomijo, vendar hkrati opozarja, da poleg avtorja pomen besedila, kot Zakon v Kafkovi paraboli, varuje sistem mogočnih vratarjev: uredniki, založniki, kritiki, akademiki, knjižničarji itd. (Derrida 1991: 181-220, Derrida 1998).

Foucault pri tovrstnem razumevanju literarnega bistva napravi še korak dlje. Mladi Foucault se je, podobno kot Theodor Adorno, ukvarjal z vprašanjem utopične in emancipatorne moči književnosti. Dojemal jo je kot protidiskurz in kot prostor emancipacije, svobode ter transgresije, prek katerega radikalno izstopamo iz prostora zahodne metafizike (Širca 2010), ki daje prednost prezenci in logosu (Derrida 1998). V tem prostoru naj bi se prepustili toku nerazuma, »nasilju pisave«, bodisi blagozvočnemu bodisi absurdnemu ritmu gibanja označevalcev, ki trka in prestopa pragove meje zunanjosti in notranjosti, prek katerih se avtor in bralec kot subjekta razpršita, izgineta in iz tega procesa izstopata drugačna ter preobražena. Foucault je kasneje pod vplivom svojih arheoloških raziskav sklenil, da se spoznavnih, etičnih in estetskih razsežnosti literarnega dela ne drži nikakršna emancipatorna moč. Književnost je le diskurz med diskurzi, niz institucionaliziranih vrednot in praks, med katerimi je tudi avtor zgolj proizvod razmerij moči in diskurzov, ki ga določajo kot v specifično okolje umeščenega posameznika. Pisanje torej ni več akt osvobajanja in prestopanja pragov, temveč je zgolj ena od praks, ki v določenem narativnem kodu oziroma literarni obliki reproducira že obstoječe ideologije, pri katerih ima avtor navsezadnje manjšo vlogo, saj še zdaleč ni edini, ki besedila avtorizira (Freudlieb 1995, Širca 2010).

Delo empiričnega sociologa Pierra Bourdieuja stežka umestimo v poststrukturalizem, čeprav proučuje strukture, ki strukturirajo. Za kulturološke pristope k literaturi je lahko pomembno, saj s konceptom habitusa osvetljuje fiziološko stran Focaultovega diskurza, prek teorije literarnega polja pa diskurz presega. $\mathrm{Na}$ primeru Bourdieujevih raziskovanj lahko pokažemo, da sta etična in spoznavna razsežnost že konstitutivni pogoj za estetsko razsežnost, kar ponazarja pojem habitusa. Količina spoznanja in kvaliteta občutenja sta odvisni od količine in kvalitete nakopičenega dela oziroma kapitala, od trajnih umskih in telesnih (pre) dispozicij, ki jih posameznik akumulira v procesu akulturacije (Bourdieu 1986: 17-18). Bourdieu namreč trdi, da poleg ekonomskega kapitala obstajajo tudi socialni, politični in kulturni kapital, ki se prav tako pojavljajo v materialnih, simbolnih - za naš kontekst najpomembnejših - utelešenih oblikah. To pomeni, da so družbena razmerja utelešena $\mathrm{v}$ posamezniku in da imajo posamezniki iz različnih okolij in družbenih slojev različne okuse, znanja, vrednote in težnje. Po Bourdieuju literaturo čutimo, spoznavamo in vrednotimo le v skladu z lastnim habitusom, ki ga le delno sestavlja tisti del simbolnega kulturnega kapitala, pridobljenega $\mathrm{v}$ procesu institucionalnega izobraževanja, čeprav se naš habitus hkrati dopolnjuje in spreminja. Ta protisubjektivna obravnava posameznika kaže, da literarno delo ni zgolj proizvod ustvarjajočega in reflektiranega delovanja posameznikov (Stanković 2005: 53), poleg raziskovanja konteksta (avtorja) pa je lahko uporabna tudi pri analizi literarnih reprezentacij (npr. telesnih praks in sociolektov).

Iz habitusa izhajajoče dojemanje literature pa je zgolj fragment Bourdieujeve sistemske teorije literature, ki temelji na ideji proučevanja literarnosti, tistega, kar 
literaturo kot umetniški diskurz ločuje od drugih diskurzov (Virk 2007: 109). ${ }^{6}$ Zato Bourdieu piše o literarnem polju, »tj. o sistemu ustanov, diskurzivnih praks, habitusov, miselnih predpostavk in metajezika, v katerem leposlovje nastopa kot avtonomna, avtentična, poetična in imaginativna jezikovna ustvarjalnost« (Bourdieu $1996^{7}$ v Juvan 2006: 214).

Zato je Bourdieujev pristop $\mathrm{k}$ literaturi v posebnem odnosu do tridelne raziskovalne sheme, ki si jo delita kulturologija in literarna veda. Če se v njegovi teoriji osredotočamo bolj na kontekstualne poudarke, ki so osrediščeni s pojmom habitusa, je zaradi nasprotovanja subjektivizmu in zaradi družbene determiniranosti literature njegova teorija vzporedna teorijam ideologije in teorijam diskurzov. Če pa literaturo obravnavamo kot literarno polje, Bourdieujeva teorija preči tako kontekstualne študije, metode besedil, saj z ozirom na literarnost presega teorije ideologije in teorije diskurzov in proučuje tisto, kar je literaturi lastno.

Primer kulturološkega pristopa, ki analizira kontekstualne značilnosti literarnega dela v razmerju do njegove vsebine in oblike ter se osredotoča na univerzalno politično opolnomočenje, je koncept manjšinske književnosti. Manjšinska književnost je eklatanten primer kulturološkega pristopa zaradi proučevanja vezi med reprezentacijami in razmerji moči v danem zgodovinskem kontekstu. Študija vsebuje bogato analizo avtorjevega medkulturnega položaja, pri čemer upošteva celotno literarno polje. Gre za koncept, ki ga ob vnovičnem branju Franza Kafke, praškega pisatelja mnogoterih identitet, začrtata Gilles Deleuze in Felix Guattari. Njuna opredelitev značilnosti manjšinske književnosti namreč upošteva kompleksna razmerja med avtorjem in jezikom v odnosu do razmerja med manjšinsko in večinsko kulturo (večkulturna Praga, nemščina kot jezik izobraževanja in poslovanja, uradniške institucije Avstro-Ogrske, kapitalizem in zavarovalnice, češki nacionalizem, antisemitizem). Manjšinska književnost je književnost, ki jo piše manjšinska kultura v jeziku večinske kulture. To lingvistično prilagajanje in transfer se manifestirata $v$ osiromašenem jeziku, $v$ detemporalizaciji in deteritorializaciji notranje zgradbe literarnega dela ter v kolektivnosti in političnosti subjektivnega izjavljanja glavnih protagonistov, ki skušajo razrešiti družbeno proizvedene medgeneracijske konflikte (Deleuze in Guattari 1995). ${ }^{8}$

Koncept manjšinske književnosti pa je uporaben tudi v sodobnih literarnih razpravah. Prek preobračanja in analiziranja binarnih nasprotij - kot dekonstrukcijskih pogojev za kulturološko branje, ki se odreka ultimativni resnici ter notranjemu bistvu literarnega dela, bi lahko trdili, da je manjšinska književnost v resnici svetovna literatura. Izkustvo marginalnosti, drugosti in izgubljenosti postaja danes domače vedno večjemu številu ljudi zaradi številnih razlogov, ki ljudi bodisi deteritorializirajo bodisi detemporalizirajo, jih materialno ali simbolno razlaščajo. V tovrstnem pogledu je jasno, da razmerja med estetsko (čutno), spoznavno (kognitivno) in

\footnotetext{
${ }^{6}$ Obstaja tudi ideja, da je literatura osrednji diskurz med diskurzi, saj je edina čista reprezentacija, zaradi česar je nad kulturo in ideologijo (Riffaterre $1995 \mathrm{v}$ Virk 2007: 113).

${ }^{7}$ The rules of art: genesis and structure of the literary field (1996).

${ }^{8}$ Manjšinsko književnost so teoretsko z enako mero posvojile kulturne študije in postkolonialne študije zaradi nekaterih poststrukturalističnih premis, ki analizirajo razsrediščenje subjekta, pomena ter nehieararhično organizacijo vednosti, naslavljajo razmerje med hibridnostjo in kolonializmom ter dajejo politično oporo ideji o večkulturni družbi.
} 
etično (ideološko ali vrednostno) vlogo in razsežnostjo literarnega dela, kot jih zarisuje tradicionalna literarna teorija, niso izključujoča, ločena in nevtralna. Ker manjšinska književnost analizira različne literarne elemente v Kafkovi literaturi, ki bralcu onemogočajo zavzemanje subjektnih pozicij (t. i. linijo bega), se navezuje na eno od temeljnih vprašanj, ki jih postavljajo teorije ideologije - kako ubežati ideološki interpelaciji. Ker manjšinska književnost teoretsko-pragmatično temelji na pomembni vlogi, ki jo pripisuje ponovnemu branju, pa se po objektu proučevanja približa tudi recepcijskim študijam.

\subsection{Teorije ideologije}

V kulturnih študijah 20. stoletja je na preučevanja kulturnih, v našem primeru literarnih fenomenov, ključno vplivala misel Karla Marxa, Theodorja Adorna, Györgyja Lukacsa, Louisa Althusserja in drugih teoretikov, ki so poudarjali vlogo ideoloških komponent popularne in klasične kulture oziroma literature pri preprečevanju univerzalne emancipacije, proizvodnje odtujitve in reprodukcije nepravičnih družbenih razmerij (Debeljak 2002 v Debeljak idr. 2002: 73-94). Podobno kot v primeru Bourdieujeve teorije, kjer so družbena razmerja vpisana v posameznikov habitualno določen okus (estetsko doživljanje), je v estetski teoriji, ki izhaja iz marksizma, znana teza, da so družbena razmerja vpisana v estetsko razsežnost literarnega dela (slog, pisava). V teoretski diskusiji o utopičnem potencialu modernistične književnosti sta jo različno zagovarjala Adorno in Lukacs. Adorno je dajal prednost estetski razsežnosti kot avtonomnemu območju, ki ga ne smemo razlagati prek spoznavnih in ideoloških učinkov, Lukacs pa je estetsko formo razumel kot neposredno ideološko preslikavo, katere spoznavna vloga je premosorazmerna s kakovostjo posnemanja.

Adorno je verjel v utopični potencial umetniškega in abstraktnega leposlovja, v katerem je videl pribežališče pred zatiranjem, jezik, ki si ga ni mogoče enoznačno ideološko prisvajati. V modernističnih tehnikah potujitve (ekspresionistični izrazi, tok misli, samonanašalnost, polisemičnost) je prepoznaval utopično formo, ki zahteva in ustvarja kritičnega in razmišljujočega bralca. Namesto ideološkim razsežnostim književnosti je dajal prednost estetski razsežnosti, ki pa je ne smemo enačiti z literarnim bistvom. Ker je bistvo zaradi kameleonskega značaja jezika nereprezentativno, ga je nesmiselno iskati, saj vsaka demistifikacija in dekonstrukcija (marksistična, feministična, poststrukturalistična, psihoanalitična) literarno delo namreč razvrednotita in estetsko izkušnjo podredita ideološki klasifikaciji, prek katere se racionalna misel vrača k mitološki misli (Adorno 1997 in 1999). ${ }^{9}$

Lukacs je imel do modernistične književnosti precej bolj kritičen in distopičen odnos. V popačeni estetski formi ni prepoznaval prostora svobode pred zatiranjem.

${ }^{9}$ Vračanje k mitološki misli je namreč hrbtna stran dialektičnega procesa razsvetljenske dominacije, ki skuša nekonceptualno in kaotično, »naravno« resničnost ukrotiti z jezikom kot primarnim sredstvom za normalizacijo in nadzorovanje narave in $\mathrm{z}$ domnevno nevtralnimi ter objektivnimi koncepti ter teorijami. Po Adornu je tudi literarno delo proizvod dialektike racionalnosti - vsako je obteženo s prvinskim jezikovnim »prevarantstvom«, ampak prav tista potencialnost novih pojmovanj, nabor drugačnih možnosti, ki ga vsebuje, bi morala po Adornu ostati avtonomna in negativna - neidentična in akategorična (Stewart 2006: 9-25). 
Kot Adorno je tudi on izpostavil zavajajoč značaj književnosti, vendar ga ni povezal z univerzalnim značajem jezika, temveč s partikularnostjo modernistične estetske oblike, ki je zavajajoča, solipsistična ter odtujujoča, saj mistificira družbena razmerja, ki bi jih književnost po Lukacsu morala obelodaniti skozi realistični prikaz obstoječih družbenih razmerij in ne prek njihovega estetskega popačenja. Po Lukacsu je abstraktna, umetniška, fantastična in ekspresionistična književnost nihilistična, saj proizvaja odtujenega in dekadentnega bralca, ki se ni sposoben na aktivističen način spoprijeti z nepravično resničnostjo, z resničnostjo, ki jo najbolj odraža prepad med revnimi in bogatimi. Čeprav je Lukacs verjel v utopični potencial književnosti, je le-tega pripisoval realizmu, kar pomeni, da je dajal prednost estetski kategoriji, ki na najbolj približen, mimetičen način vsebuje spoznavno razsežnost in zagovarja tako vlogo književnosti. Lahko bi rekli, da je pri tem spregledal prav to, kar je poudarjal Adorno, namreč da so družbena razmerja že v osnovi popačena z jezikom. To pomeni, da je »realistično« prikazovanje obstoječe dejanskosti vselej ideološko in da onemogoča spoznavanje objektivne resničnosti. $\mathrm{V}$ tem smislu ima več spoznavnega potenciala književnost, ki prek estetske mnogoterosti prikazuje resničnost na neobičajen način (Lukacs 1963: 47-91).

O literaturi kot o estetski obliki, ki je določena z ideologijo, so pisali tudi Althusser, Etienne Balibar, Pierre Macherey in Michel Pêcheux (1980). Althusserjeva teza, iz katere izhajajo tudi njegovi učenci, je bila, da je literatura le del kulturnega ideološkega aparata (države), ki prek kategorije imaginarnega bralca interpelira v vnaprej dane subjektne pozicije, ki onemogočajo razumevanje celote resničnih (in nepravičnih) družbenih razmerij. Po althusserjancih je diskurz neločljiv od ideologije, bralčevo estetsko doživljanje, ki se vzpostavlja prav tam, kjer deluje ideologija, pa ji je povsem podrejeno (Pecheux 1980: 123). Teorije ideologije torej ne ločujejo med estetskimi in ideološkimi razsežnostmi literature. Literarni učinek je a priori ideološki učinek, ker se konstituira kot kompleksen učinek, ki »imaginarno razrešuje neko protislovje« (Balibar in Macherey 1980: 261), in ker bi rad, da ga prepoznamo kot »literarni učinek«.

\subsection{Recepcijske študije}

O omejitvah althusserjanskega razumevanja literature v razmerju do estetskega in imaginarnega pišeta Hans Robert Jauss (estetika recepcije) in Wolfgang Iser (estetika učinkovanja), temeljna avtorja konstanške šole. Njuni usmeritvi skušata razumeti pomensko učinkovanje literature $\mathrm{v}$ različnih zgodovinskih obdobjih in družbenih okolij, s čimer pokažeta, da so ideološke razsežnosti literature le del njenega učinkovanja (Virk 2008: 213).

Namen estetike recepcije je premostiti prepad med zgodovinskim in estetskim, ki se v kulturološkoraziskovalnem okviru nanaša na vez med delom in občinstvom. ${ }^{10}$ Jauss to stori $\mathrm{z}$ rekonstrukcijo literarne zgodovine prek nekaterih

${ }^{10}$ Estetika recepcije je do neke mere združljiva s konceptom krogotoka kulture, ki so ga oblikovali Paul du Gay, Hall in njuni sodelavci, ki so trdili, da pomeni kulturnih artefaktov nikoli niso končni, saj se sočasno predstavljajo skozi oblikovanje in oblikujejo skozi predstavljanje na ravneh proizvodnje, potrošnje, identitete in regulacije (Stanković 2006: 105-107). 
ključnih poudarkov, ki so v skladu z neesencialističnim razumevanjem literature: s prehodom od zgodovinskega objektivizma do estetike recepcije, s preseganjem psihologizma, s prisojanjem umetniške vrednosti glede na bralčeve horizonte pričakovanj, s preseganjem metafizičnega pojmovanja bistva, s pojmovanjem literarnega dela kot dogodka, s sinhrono-diahronim proučevanjem, z upoštevanjem družbene vloge literature (Jauss 1970 in $1980 \mathrm{v}$ Virk: 218-220).

Iserjeva estetika učinkovanja izhaja iz ideje o pomenski nedoločenosti dela, zaradi česar je potrebno analizirati razmerje med delom in pomenodajalcem (bralcem), kar se ujema s Hallovima postulatoma odkodiranja in reprezentacije. Namen estetike učinkovanja je, da »/p/ri bralcu analizira čustvene pomene, pri besedilu pa jezikovni sestav, nato pa skuša v besedilu odkriti tisto strukturo, ki proizvaja pomen« (Virk 2008: 223). Pomen je zato, kot pri althusserjanskem branju, v območju imaginarnega, saj se le posredno nanaša na referenčne okvirje literarnega dela. Vendar pa pri Iserju imaginarno ni več ideološko naddoločeno, temveč ga lahko dojemamo v smislu »nedokončne fluidnosti, nenehnega postajanja skozi logiko določljivega« (Castoriadis 1997 v Potocco 2012: 17).

Jauss in Iser literaturo osvobodita ideološke določenosti, saj v njuni teoriji literatura ni več ideološka preslikava. Ker nastaja pomen v t. i. polju imaginarnega, se med literarnim delom in bralcem še vedno preigravajo različne ideologije in subjektne pozicije, ki pa jih bralec, v kolikor ga ne obravnavamo kot pasivni objekt podrejanja, ne zaseda v celoti. Premisa, ki skozi recepcijske študije poveže vse tri elemente kulturološko-literarne raziskovalne sheme in zaokroži Hallov krogotok kulture, je, da bralci v različnih družbenih položajih, kulturnih okoljih in časovnih obdobjih berejo literaturo bodisi odčarano bodisi utopično.

\section{Zaključek}

V članku ugotavljamo, da kulturološka branja literature niso lastna le kulturologiji, temveč tudi sodobni literarni vedi, s katero si delita trodelni raziskovalni model. Različne segmente tega modela (kontekst/avtor, tekst/literarno delo, občinstvo/ bralec) analizirajo skupni filozofsko-teoretski tokovi poststrukturalističnih teorij, Frankfurtske šole, teorij ideologij in recepcijskih študij, ki rahljajo in politizirajo esencialistično tradicionalno literarno teorijo. Eklektična zmes omenjenih teoretskih izhodišč kaže, da so razmerja med spoznavno, etično in estetsko razsežnostjo v literaturi kompleksna in prepustna. Če piratske kulturne študije jemljejo literarni vedi avtonomnost, literaturi pa njen čar, medsebojna izposoja konceptov kaže na to, da tudi kulturne študije izgubljajo lasten predmet proučevanja oziroma da se področje teoretsko izčrpava in morda vstopa $\mathrm{v}$ obdobje permanentne krize, ki zahteva nov paradigmatski preskok.

\section{LITERATURA}

Theodor ADORNO, 1999: Beležke o literaturi. Ljubljana: Cankarjeva založba.

- -, 1997: Prisms. Cambridge; London: MIT PRESS.

- -, 1972: Žargon pravšnjosti. Ljubljana: Cankarjeva založba. 
Louis ALTHUSSER, Etienne BALIBAR, Pierre MACHEREY in Michel PÊCHEUX, 1980: Ideologija in estetski učinek. Ljubljana: Cankarjeva založba.

Pierre BOURDIEU, 1986: The Forms of Capital. Handbook of Theory and Research for the Sociology of Education. Ur. John Richardson. Westport, CT: Greenwood. 241-58.

Aleš DEBELJAK, 2002: Birmingham in Frankfurt: vrt kulturnih študij s potmi, ki se razhajajo. Cooltura: Uvod v kulturne študije. Ur. Aleš Debeljak in drugi. Ljubljana: Študentska založba. 71-120.

Gilles DELEUZE in Felix GUATTARI, 1995: Kafka: za manjšinsko književnost. Ljubljana: Literarno-umetniško društvo Literatura.

Jacques DERRIDA, 1991: Acts of Literature. New York: Routledge.

- -, 1998: O gramatologiji. Ljubljana: Analecta.

Dieter FREUNDLIEB, 1995: Foucault and the Study of Literature. Poetics Today 16/2, 301-344.

Meta GROSMAN, 2004: Književnost v medkulturnem položaju. Ljubljana: Znanstveni inštitut Filozofske fakultete.

Marko JUVAN, 2006: Literarna veda v rekonstrukciji: uvod v sodobni študij literature. Ljubljana: Literarno-umetniško društvo Literatura.

Matjaž KMECL, 1995: Mala literarna teorija. Ljubljana: Mihelač in Nešović.

Janko KOS, 1995: Očrt Literarne teorije. Ljubljana: DZS.

Georg LUKACS, 1963: The Meaning of Contemporary Realism. London: Merlin Press Limited.

Marcello POTOCCO, 2012. Nacionalni imaginariji. Literarni imaginariji. Različice nacionalnega poziva $v$ literaturi in literarnih kontekstih. Ljubljana: Pedagoški inštitut.

Aljoša PUŽAR, 2010. Piratical Cultural Studies: Transgressive Individualism Reconsidered. Cultural Studies $\leftrightarrow$ Critical Methodologies 10/3, 187-198.

Peter STANKOVIĆ, 2002: Kulturne študije: pregled zgodovine, teorij in metod v Cooltura: Uvod v kulturne študije. Ur. Aleš Debeljak in drugi. Ljubljana: Študentska založba. 11-70. - -, 2006: Politike popa: Uvod v kulturne študije. Ljubljana: Fakulteta za družbene vede.

Martin STEWART, 2006: Literature and the Modern System of Arts: Sources of Criticism in Adorno. Adorno and Literature. Ur. David Cunnigham in Nigel Mapp. London, New York: Continuum. 9-25.

Alen ŠIRCA, 2010: Foucaultovi pogledi na literaturo. Primerjalna književnost 33/1, 41-61.

Tomo VIRK, 2007: Primerjalna književnost na prelomu tisočletja: kritični pregled. Ljubljana: Založba ZRC SAZU.

--, 2008: Moderne metode literarne vede in njihove filozofsko-teoretske osnove. Ljubljana:

Znanstvena založba Filozofske fakultete Univerze v Ljubljani.

\section{CULTURISTIX - CULTUROLOGICAL READINGS OF BELLES LETTRES}

In the article, we present the philosophical-theoretical currents that contributed to culturological shifts in literary theory in the last decade of the twentieth century as a response to the crisis of literary science. In addition to the postmodern epistemological shift and the crisis of the legitimisation of knowledge, one of the factors that contributed to the culturological reconstruction of literary science was the essentialist traditional literary approach to literature, which was rendered obsolete in the face of new social and political developments. 
The universal premise on which culturological readings of literature are based includes the distinction between popular and elite literature, latent social structures that are present in the literary work, the authorial position of the writer, and the relativity of the literary essence. The primary feature of the culturological approach to literature is the comprehensive contextualisation of the literary work. Culturological readings orient the literary essence outwards (towards socio-economic relations, biographical elements, publication, distribution, consumption, and reception), while traditional literary theory orients the literary essence inwards (towards literary depth and width). These premises are common to culturological and contemporary literary approaches, both of which make use of the tripartite research model (context/author, text/literary work, audience/reader).

We address the main components of this research model in an overview of several important post-structuralist theories (Jacques Derrida, Michel Foucault, Pierre Bourdieu, Gilles Deleuze, and Felix Guattari), the Frankfurt school's critical theory (Theodore Adorno and György Lukacs), theories of ideology (Louis Althusser and his followers), and reception studies (Hans Robert Jauss and Wolfgang Iser). In the article, we also present convergences and divergences between these different theoretical-philosophical currents in terms of their relationship to the aesthetic, cognitive, and ethical dimensions of the literary work. 


\title{
Konstrukcija ženskog identiteta u poeziji Tina Ujevića
}

\author{
Miodarka TePavČEVIĆ \\ Univerzitet Crne Gore, Filološki fakultet, Danila Bojovića bb, \\ ME-81400Nikšić,migat@t-com.me
}

\begin{abstract}
1.01 Izvirni znanstveni članek - 1.01 Original Scientific Article
Nova prebiranja Ujevićevih besedil so omogočila analizo strukture jezikovnega diskurza o ženski in tudi analizo lingvističnih izrazov vrednostnih stališč o njej. V članku se avtorica posveti analizi ženske identitete, ki v kontekstu širšega diskurza osvetli številne podrobnosti Ujevićevih pogledov na ženske. S tem delom želimo izpostaviti pomembnost in vlogo ženske v njegovi poeziji in odstreti še en del njegove zapuščine. Od njegovih zgodnjih pesniških zbirk in rim do bolečih verzov in zrelih od so Ujevićeva dela prežeta $\mathrm{z}$ vilami in drugimi mitološkimi boginjami, ljubljenimi in nedosanjanimi ženskami, ki s svojo močjo vseprisotnosti skupaj ustvarijo glas ženske. Definiranje tega harmoničnega zvoka številnih žensk se kaže kot neobhodni del naracije in nosilec sporočila poezije.

New readings of Ujević's texts have made it possible to analyse the structure of the linguistic discourse about women as well as the linguistic expressions of value-based attitudes toward them. In the paper, the author deals with an analysis of female identity, which in the context of the wider discourse illuminates many details of his views towards women. With this work we would like to point out the significance and role of women in Ujevićs poetry and reveal another segment of his poetic legacy. From his earliest poetry collections and initial rhymes, to the painful verses and mature odes, Ujević's poems are full of numerous fairies, mythological goddesses, women who were loved and those with unfulfilled dreams, who through the power of omnipresence together constitute the voice of one woman. The defining of this harmonic voice of many women appears as an indispensable part of the narrative and the carrier of the poetic message.
\end{abstract}

Ključne besede: Tin Ujević, hrvaška literatura, ženska identiteta, ljubezen

Key words: Tin Ujević, Croatian literature, female identity, love

Jer meni treba moćna riječ, jer meni treba odgovor, i ljubav, ili sveta smrt Tin Ujević: Svakidašnja jadikovka

\section{Uvod}

Univerzalnošću raspona i koordinatama pjesničkog svijeta, ostvarenom sintezom modernog i klasičnog poetskog iskustva, rafiniranom formom, originalnom i sugestivnom pjesničkom vokacijom poezija Tina Ujevića dostiže europsku razinu. Svoj 
duh je bogatio na tekovinama udaljenih kultura, filozofiji religija i poetika i bio otvoren otkrićima i stremljenjima ljudskog duha (Sang Hun Kim 2016: 103-110). Ovaj neobični boem podredio je svoj život pjesničkom stvaranju i stvaralačkoj slobodi. Klasik izvorne umjetnosti, strastveni esteta - skeptik i eklektik, erudita i zavjerenik mistike i tajne, pjesnik ljubavi i smrti, uspio je da ih pomiri u ljepoti kao njihovom jedinstvu i najvišoj emanaciji ljudskog duha. Tin nije bio jedinstven, bio je "pjesnik lirskih susreta i misaonih katarzi, otvoren svim doslusima od Sapfe do Verhaerena, senzibilan na stare i nove, estetske i misaone, naboje — od drevne Kine do evropskog modernizma, unanimista i futurista" (Šimundža 1982: 240).

Život i djelo Tina Ujevića bili su u velikoj mjeri uvjetovani ne samo obilježjima njegovog mnogostranog duha nego i drugim moralnim i duševnim osobinama koje su tvorile njegovu sveukupnu ličnost. Ujević je bio izuzetan po svemu - po svojim shvatanjima i životu, po svojoj viziji svijeta i moralnim načelima. On je veliki revolucionar u kome su sjedinjeni unutarnja snaga, emocionalnost, misaona zrelost, virtuoznost umjetnika, spiritualnost i kozmički osjećaj svijeta. Njegov je život gorak, dostojanstven, složen i nedokučiv. On je sazdan u znaku pobune protiv urođenih etičkih i estetičkih normi koje su sputavale misaoni i svaki drugi razvitak čovjekov, probijajući tako nacionalne okvire da bi postao svjetski pisac (Marković 1962: 483, 485-486).

Skoro svi kritičari se slažu da je riječ o izuzetnoj ličnosti hrvatske kulture koja se svojim građanskim statusom, ponašanjem, svojim idejama, cjelokupnim životom, izuzela od sredine u kojoj živi, ograđujući se od drugih ljudi ironijom, intelektualnom superiornošću, ignoriranjem svakidašnjice i normi građanskog života, boemskom ekstravagancijom. "Jedinstven u tom smislu u hrvatskoj književnosti prve polovice XX. stoljeća - i po tome nikome sličan - Ujević je bio nošen ovim strujama: parnasovstvo i simbolizam (u prvoj fazi stvaranja), te ekspresionizam, simultanizam, kubizam, futurizam i nadrealizam (u kasnijim fazama)" (Stamać 2004: 77).

Ujević je univerzalni pjesnik svjetskih dimenzija, čiju poeziju karakterizira savršenstvo forme, misaonost, bogatstvo slika i zvonka muzikalnost. On "pripada onoj rijetkoj vrsti umjetnika koji, čim nešto dodirnu... odmah to i ožive. Bio pustolov i fanatik svoje umjetnosti, ponosni usamljenik osuđen da živi dvostrukim životom - kao legendarni boem pred ljudima i kao kontemplativni sanjar u svojoj samoći. Tako je bio razapet njegov genije koji je nosio teret duha i života. Ovaj svetac poezije uvijek se sudarao sa stvarnošću, pa opet nije postojao poklonik očajanja pred njom... Sve je kod njega s onu stranu uma u nadzemaljskim jezama i proročanskim grčevima, jer je bio alhemičar-pjesnik koji je od kamena pravio plamen" (Gajević 1988: 280).

${ }^{1}$ Pjesničko djelo hrvatskog pjesnika Tina Ujevića pobuđivalo je u proteklim desetljećima veliku pozornost kulturne javnosti i književne kritike koja je bila motivirana ne samo literaturnim razlozima nego i potrebom da se pronikne u smisao jednog života koji je po mnogo čemu bio izuzetan - vidjeti detaljnije Gajević 1988; Goranović 2008: 17, 19, 335-344; Sabrana djela Tina Ujevića 1963-1966: 383-458, 457-484. Ljiljana Šarić i Ellen Veit napisale su bibliografiju radova o Tinu Ujeviću od 1981. do 2003. Bibliografija radova o Ujeviću do 1967. objavljena je u Sabranim djelima 1967 (Šarić 2006: 153-158). 


\section{Jezičko vrjednovanje - Ujevićev model žene}

Tin Ujević nije uobičajen pjesnik, njegovo djelo je i danas više nego aktualno, a dijelom i neistraženo. Uzimajući u obzir dosadašnje unekoliko zanemareno proučavanje Ujevićevog djela s lingvističkog aspekta ${ }^{2}$, bavit ćemo se analizom ženskog identiteta koji na širem diskursnom planu osvjetljava mnoge pojedinosti njegove vizije žene. Nova čitanja Ujevićevih tekstova ${ }^{3}$ omogućila su da se analizira struktura jezičkog diskursa o ženi, kao i lingvistički izrazi vrjedonosnih stavova prema njoj. U radu ćemo identificirati, izdvojiti, klasificirati i analizirati ovaj leksički sloj koji se odnosi na koncept žene. Promatrat ćemo semantička i sintaksička sredstva u jezičkom valoriziranju.

Ovim radom želimo istaknuti značaj i ulogu žene u Ujevićevoj poeziji i tako upotpuniti još jedan segment njegove pjesničke zaostavštine. Od najranijih zbirki i početnih rima do bolnih stihova i zrelih oda, kroz Ujevićeve pjesme prodefilovale su mnogobrojne vile, mitološke boginje, voljene i nedosanjane drage, koje svojim snagom sveprisustva zajedno čine glas jedne žene. Definisanje tog unisonog glasa mnogobrojnih žena javlja se kao nezaobilazni dio narativa i nositelj određene poetske poruke.

Istraživanja i rasprave o ženi, njenim osobinama, stereotipima, predstavama, uvijek su pobuđivali veliku pozornost i kontroverzna mišljenja. Ne samo u laičkim već i u znanstvenim raspravama o ženi često se pod maskom racionalnog i objektivnog diskursa skrivaju emocije i predrasude. O ženama su ispisani milijuni stihova i napisane najljepše ljubavne pjesme, stvarani romani, naslikane najljepše slike, snimani filmovi... Priča o ženama zbog toga nema ni početka ni kraja, uvijek će ostati nedorečena i nedokučiva... jer takva je i žena (Milosavljević/Klem 2008: 3).

Koje su najvažnije značajke Ujevićeve ljubavne poezije? Gdje se nalaze njena duhovna ishodišta i uporišta, njeni stvaralački uzori i ideali? ${ }^{4}$ Što je žena? U pjesničkoj prozi Poluistine kaže: "Jedna magična žena prođe, i pretvori se u bezbroj drugih. Gužva žena: jedna ima podbradak njezin, druga boju obraza. A svima je zajednička prolaznost" (SD:1963-1966, 378). No, Tin, na drugom mjestu navodi: "A u malom broju žena našao sam na Izvanrednu Iskru koja bi trebala biti red reda. No jedina o kojoj bih mogao govoriti (s velikim Ž) bila bi ta koja bi, žena, ukinula spol i sačuvala samo psihu" (SD:1963-1966, 235). Dakle, u ljubavi je tražio spiritualnu zanesenost, a nalazio je bol i san, pa je te tragove nastojao potisnuti u sebi i pronaći luku u drugim stvarima - poeziji, rodnom mjestu, prostranom Kristu.

Počevši od prvih stihova iz Ujevićeve razvojne faze, preko glavnih ljubavnih pjesama, susrećemo se sa mnogobrojnim ženskim figurama i simboličkim dimenzijama žena. Samo u naslovima, uočili smo veliki broj pjesama koje izravno ili

\footnotetext{
${ }^{2}$ Vidjeti o tome radove: Tomić 1981; Peti 1981; Težak 1981; Selak 1992; Šarić 2007.

${ }^{3}$ Primjere smo ekscerpirali iz Sabranih djela 1963-1966; kao i zbirke Odabrane pjesme 1957. U radu ćemo koristiti skraćenice SD, OP.

${ }^{4}$ Na poetiku Tina Ujevića utjecali su u prvom redu Dante, Petrarka, suvremena kritika pominje više imena od srednjovjekovnih trubadura do modernih romantičara, ekspresionista, dadaista, unamunista, futurista, nadrealista, kao što su: Vijon, Marulić, Po, Hajne, Nerval, Bodler, Rembo, Malarme, Verlen, Niče, Matoš, Verharen, Apoliner, Vitman, Valeri, Breton (Goranović 2008: 26).
} 
neizravno sadrže ime neke ženske osobe, pa su tako mnoge od njih naslovljene kao: Naše vile (OP, 28); Molitva Bogomajci za rabu božju Doru Remebot (OP, 38); Žene među kraljicama (OP, 48); Misao na nju (OP, 52); Vivijani (OP, 56); Žene (OP, 60); moja Vjerenice (OP, 67); Razapeta Afrodita (OP, 168); Čari žene (OP, 228); Vrućica od žene (OP, 229); Doživljaji zatočene Sfinge (OP, 343); Savremene gospođice (OP, 335).

Ujević je u poeziji stvorio najcjelovitiju misao i viziju o ženi, kao složenom, teško saznatljivom, trošnom, pa ipak vječnom biću. Na tom putu pisac je uvijek ostao vjeran percepciji njezina lika. On o njoj govori i s poštovanjem i s prezirom, slavi je i proklinje, ona je i radost i patnja, i zagonetka. Analizirajući Tinov odnos prema ženama u pjesmama, zapažamo varijacije od ljubavi i strasti koje očituju nešto mistično i zabranjeno do čistih, petrarkističkih kanconijera o doživljaju ljubavi kao vrhunca sreće.

Ujevićev opšti model obuhvata ženske realne (denotativne), konceptualne (pojmovne) i formalne (izražajne) komponente. On je sastavljen od kategorija jezičkog, književnog i stilskog modela, koji se međusobno prožimaju obrazujući složeni sustav odnosa. ${ }^{5}$

U pjesnikovom viđenju žene javljaju se tri fundamentalna odnosa - identičnost, sličnost i različitost. Žena se dovodi u vezu sa drugim živim bićima, mrtvim predmetima i prirodnim pojavama.

\begin{abstract}
Ja te tako motrim kraj smeđih portala / kao neko biće iz Višega Svijeta (SD, 55); Sveta k'o regina Helena iz rake (OP, 28); Ona je u podzemlju duše čudesni fantom skriti (OP, 231); Ona je kao zvono što tromo u vidike kuca (OP, 231); Ona je kamen zavitlan u kolobare vode (OP, 231); Ona je šedrvan što kroz tišine muca (OP, 231); Ona u podrumu bića kao žižak svjetluca (OP, 231); Ona je riječ kakva se nije progovorila (OP, 231); Ti si pod lukom prozora doživljaj snene mašte (SD, 143); K’o zora ruža u docnome inju (OP, 37); Roso, Mistična Ružo (SD, 63); Ti si nevina rosa (SD, 84).
\end{abstract}

Sa druge strane, u piščevom poimanju žene dolazi i do izražaja i raznolikost, nesklad između sadržaja i forme, riječi i djela.

Ona je ponos i gubitak vida, i ljubav nema koprene ni stida (SD, 55); Nad mojim mrakom sijevaju tek tvoje, / tuđinska ženo, samilosne oči (OP, 123); A ti što smiješkom vrijeđaš ropsku patnju (OP, 135); Al ona žena idealna / što nemir duše žudi strti / ima u jami oka stalna / duboki, kruti oganj smrti (OP, 131); Ti si u vijencu snova sva dobrostiva, / budi da čini ruku širiš, o Radostiva, / budi da tajnu suzu briššs, o Žalostiva (SD, 73).

Ova sredstva imaju značajnu ulogu u skretanju pozornosti čitatelja i stvaranju negativne ili pozitivne slike referenata. U sintaksi vrjednujućih struktura u određenim usporednim elementima otkrivaju se asocijacije koje izjednačavaju ženu sa drugom pojavom i pri tome, kada je riječ o negativnom ili pozitivnom vrjednovanju, daju joj veći stupanj negativnoga/pozitivnoga.

Značenje je jedno od važnih obilježja u njegovoj poeziji. Ujevićev model se odlikuje dvojnom semantikom, koju čini značenje žene, a odnosi na njenu ulogu u društvu, i drugi - žena kao značenje. Zapravo žena se promatra u trokutu denotacija (živo biće), signifikacija (pojmovna predstava o ženi) i nominacija - jezički

\footnotetext{
${ }^{5}$ Detaljnije o ovim koncepcijama vidjeti rad Tošović (2005: 15-111).
} 
izraz (Tošović 2015: 28). Postoji nesklad između broja ovih kategorija, pa smo kod Ujevića zabilježili najveći broj denotata - različitih naziva za ženu:

književnica (OP, 28); banice (OP, 28); muze (OP, 28); Gospa (OP, 34); žena (OP, 34); moja Vjerenica (OP, 67); Gospo, rajska bebo (OP, 84); tužna vila (OP, 86); djevojko iz mog kraja (OP, 146); Muze (OP, 146); djevojke (OP, 218); krčmarica (OP, 294); Majko (SD, 65); Ubio je ženu, ubio je taštu (SD, 149); djeve (OP, 28); Drage rajne seste i drage, Marulova seja $i$ Dubravka, Cvijeta (OP, 28); Mučenica Zrinska Katarina, književnica, duše pobožne i jake (OP, 28); srce Amazonke (OP, 28); Jelena, mat sina (OP, 28); Sučanica gdje je Kosara, kći kralja (OP, 28); Neda i Sokolica, sjajni niz koralja (OP, 28); Koso Vivijane (OP, 33); Beta (OP, 34); Marija i Eva (OP, 34); poćerko Trećeg Boga Parakleta (OP, 36); Hjeronima (OP, 36); Vidosava (OP, 36); Marijo, zvijezdo bijelih naraštaja (OP, 38); sveta žena Dora Remebot (OP, 39); Sveta Madona naše svjetske Muze (OP, 39); Marija i Klara (OP, 68); Meluzina ili Anđelika (OP, 69); Ravijojla, bijela ljuba (OP, 73); Bogorodice (OP, 80); Tina nije mrtva, ona samo spava (OP, 81); Beatriće (OP, 86); pramajka Eva (OP, 108); Lijepa ženska imena, Renala, Ofelija, Cecil, Agrafena, i Jelena, i Klelija, imena svijetlih laži, i ljubavi i mirisa, imena bola, draži, i stobojnoga irisa (OP, 115); plašljiva Madona (OP, 119); slavna Izabela $(\mathrm{OP}, 128)$; Izoldo, cvijete bijelih ruku (OP, 135); Ksenija (OP, 142); Ines de Luna (OP, 146); Sapfo (OP, 173); Šeherezada (OP, 195); odliva se iz kalupa vrelih žena tvojega kova, / žena kôšto Belkis, Lilit, Tamar nisu (OP, 194); Julijeta (OP, 300); meni ne liči društvo lijepih djevojaka, / ali Ti, Frijo ili Afrodito, Vječita Sanjarijo, / razgali se kao nimfa samoće (OP, 155); Ne žudim za Matom Hari ni gospođom Pompadour (SD, 144).

U analiziranim pjesmama bilježimo primjere nominacije žena iz tradicionalnog, ali i religijsko-mitološkog svijeta, primjere nepoznatih, zvučnih ženskih imena. Ono što uočavamo jeste da se u njegovoj poeziji o ženi ne govori samo općenito, već se javljaju određene potkategorije pojma žene, koje ovise o društvenom, srodničkom ili generacijskom statusu. Tako se kao referent javljaju navedeni pojmovi. Oni su determinisani socijalnom pripadnošću, srodnošću, uzrastom, izgledom, zanimanjem, intelektualno-emocionalnim sklopom i sl. Imenice u Ujevićevom diskursu o ženi denotiraju konkretne (žena, majka, djevojka), ali i apstraktne pojmove (muza, vila, nimfa). Osvrnemo li se na Ujevićev opus uočavamo "mnoštvo sličnih činova imenovanja od kojih se mnogima prizivaju slavni ženski likovi iz povijesti svjetske književnosti” (Drenjančević 2018: 31).

U Ujevićevoj poeziji žena ima pozitivne i negativne osobine, ali se ponekad javlja i bez kvalitativne eksplikacije. Semantički sadržaj određuje se pomoću najfrekventnije leksike i leksičkih jedinica, koji imaju određenu vrijednost, dok sintaksička struktura podrazumijeva specifična semantičko-stilistička sredstva. Valoriziranje znači "pripisivanje ili odricanje kvaliteta, ili istovremeno i jedno i drugo" (Starčević 1998: 412). Jezičko vrjednovanje realizuje se izravno ili neizravno. Pozitivna ili negativna atribucija karakteristika je izravnog procjenjivanja, koje se ostvaruje pomoću punoznačnih riječi, odnosno sintaksema. Neizravna ocjena izražava se također kroz određenu leksiku, koja se ostvaruje kroz asocijacije, komparacije i druga stilsko-jezička sredstva (Starčević 1998: 414).

Markeri pozitivnih osobina su češći, a odnose se na:

- fizička svojstva

O ženo, s tijelom čudnim kao samet (SD, 56); gizdavih ljepota (OP, 28); idealna usta (OP, 36); miris ljepote stuji u toj kosi (OP, 108); njene su usne pune slatke varke (OP, 108); njene su ruke drhtave i žarke (OP, 108); skladna ramena $(\mathrm{OP}, 146)$; ženstvene oči $(\mathrm{OP}, 66)$; 
- umna svojstva

a duh je u tvom bogu majčinstvo žensko samo, / ti si nevina rosa (OP, 168); a mila žena (nježna vila, svila) / neće me više draganom i pažem (OP, 121); žena idealna (OP, 131); Ti si $u$ vijencu snova sva dobrostiva (SD, 73); duše pobožne i jake (OP, 28);

- Životne vrline

Svaka je od vas rođena da vlada, / i da za prijesto pruži mliječno dijete (OP, 48); Te divne žene ognjevite rase njegovana lica pokrivaju velom (SD, 190);

- socijalne vrijednosti

I bolje da me ne znadu pod časnim imenom moje majke i sestre (SD, 197).

Primjećujemo da su negativna vrjednovanja leksema, kao i tipovi njihovih leksičko-semantičkih grupa manje zastupljeni od leksema sa pozitivnim predznakom. Markeri negativnih osobina se uglavnom odnose na intelektualna i duhovna stanja, kao u primjerima:

njeno lice, tašta sfinga ispod maske (OP, 228); Ta čarobnica truje svoje eligzire (OP, 231); nebrigo žene (OP, 125); Ceri se drolji Isidori (SD, 195); Mrzim te oči mračne i duboke, I kunem te noge pred kojima padam, / $i$ altar tijela gdje u prahu ležim (OP, 108); zbog jedne žene ja propadam $(\mathrm{OP}, 120)$; kletva jedne žene (OP, 134); bludnica $(\mathrm{OP}, 68)$.

Pisac pažljivo bira leksiku, stilematičnim postupcima na sintaksičkom planu stvara vrjednosni leksički sloj. Ponekad dolazi do spoja minusa i plusa, odnosno negativnog i pozitivnog:

Je li ona mačka? hijena? avet? žena? / Amblem, mašta, uspomena, / strašna vizija s međa Nubije ili Libije? / Ona je najčudnije biće s Nila, / i nijedna žena, u mulju rijeke, pod brdom pijeska (OP, 343); košuto plaha (OP, 135).

Na ovaj način traži se aktivno angažiranje čitatelja u potrazi za rješenjem - pitanje ne pretenduje na konačnost forme niti obavijesti, već svaka riječ otvara beskrajno polje mogućnosti - što je žena u Ujevićevoj viziji?

\section{Tajne i istine o ženama u Ujevićevoj poeziji}

Smatrajući ženu tajanstvom života, on je uzdiže među kraljice i doživljava je kao apsolutnu ljepotu, san i priviđenje: jer vi ste žene među kraljicama (OP, 49); Jer ti si došla s druge strane svijeta (OP, 113). Žena je pretvorena u smisao života. Ona je uzvišena, nedostižna i neuhvatljiva, iako prema njoj duh neprestano stremi: Božanske žene, sva ljepota svijeta, i lavska gordost i plahota srne (OP, 48). Kod Ujevića se svi problemi slivaju u jedan, u problem ljubavi, ali mistično shvaćene ljubavi: Božanska ženo, gospo nepoznata, / dokle i kamo, mene misliš vući? (OP, 111).

Ujevićevo shvatanje ljubavi i žene prožeto je romantikom, idealizacijom, pa čak i krišćanskim misticizmom. On pristupa ženi kao majci i madoni. Uvija je u plašt daljine i čuda kao nešto tajno, nepoznato i transcendentno: I preklinjem te: Nepoznata reci, / kakva te tuga iz daljine draga, i još mi reci, gdje si, što si, ko si? (OP, 111); Što si? Zagonetka. (OP, 34). Ona je povod za rascvat njegovih emocija i misaonosti; uselila se u njegovu dušu i preobrazila u ideal: ljubljena ženo, ko si 
ti da jesi, / luđačku ljubav suvišno je kriti (OP, 63). Željena, a nedostižna žena, o kojoj se neprestano sanja, postaje izvor patnje i pesimizma: Molitvi mojoj cilj, ikona, a mojoj mašti san i bajka (OP, 110). I pored toga, Ujević je u iluzijama o njoj našao jedno spokojstvo i pribježište od životne zbilje.

Ujević nije pristajao na kompromise. Htio je idealnu sreću, neograničenu slobodu i potpunu ljubav. Ali pošto je idealna sreća nedostižna, a ljubav "ropstvo po definiciji”, morao se odreći obje da bi sačuvao bar težnju za slobodom, jer je za njega ljubav i alem, sitnica u rijetkoj zbirci korund vrijedan ko gradska mitnica (SD, 144), ali i ljubav je pizma (SD, 148).

U ranoj poeziji ljubav se idealizira do apsoluta, koja zauvijek ostaje nedostižna, a u čudesnim zbirkama visokog simbolizma Lelek sebra i Kolajna ljubav je dominantna tema. U Leleku sebra data je prouhovljena varijanta ljubavne poezije iskazana sonetima posvećenim idealnoj ženi - Vivijani, Dori, Remobot, Mariji, Klari, Anđeliki, Beati. Već ustanovljena težnja za apsolutnim svojstvena je brojnim stihovima Leleka sebra, u kojima je iskazana čežnja za idealnom ljubavi i potreba za obraćanjem Bogu. Žena je za njega svetinja pred kojom se klanja, a čitav život bježi od tog ideala žene i sklanja se u okrilje poezije. U Kolajni žena je povod da se ljubavno osjećanje preobrazi u ljepotu života i umjetnosti, a Ujević je štovao ljepotu kao božansko, što je izražavao i pjesnički i esejistički. Ljubavna mistika potječe iz rastrzanog pjesničkog stanja i odatle prelazi u ljepotu iskaza.

Problem žene kod Ujevića je komplikovan i protivurječan. Ona je i milosrdna, puna ljubavi i praštanja, ali i lakoumna, grešna, pohotna i koketna. Žena je i jedno kontradiktorno biće, prinuđeno da svoje slabosti prikriva glumom, jer ona ponor i plamen usred oka nosi (OP, 108); ona je ponos i gubitak vida (OP, 47). Ona je, s jedne strane, Marija, milosrdna i milostiva, očiju punih ljubavi i milošte, gotova da prašta i tješi; s druge strane, Eva, grešnica lakoumna i lakomislena, gotova da učini ma šta da bi se njena riječ ispunila, koketa:

Žena na mom pragu. Druga je pred kućom,/ Svuda, svuda žena. Marija i Eva, / avaj! Bivam grešnik. A tom ploti vrućom / kao ljuti samum i ledena Neva / struji očaj te me stvori palikućom; / doznah da mahnitah, kada ljubav pjevah (SD, 159).

Pjesnik je svjestan polivalentnosti ženske figure, pa pjeva o dvije žene - sanjao sam jutros san o dvije žene, / to su dvije duše kroz dvije razne zjene, / jedna gleda bistro, a druga kroz mene. / Koja od njih može da me strasno krene? / Oči pune magle očaraše mene (OP, 294).

Za njega više vrijedi nevina i čista žena, kojoj je sve zemaljsko pojmljivo, možda i privlačno, ali ne i toliko da bi mu se podala i odala; žena kojoj je ljubav Bog i majka njegova:

Ljubav je Bog, ne Dzeus ni Sabaot, / I zato neka je sanak blagoslovljen, / I neka pada drač i trnski plot; / Majka je Bog, ne Dzeus ni Sabaot, / I nek me čuje kada vapim slomljen / Za rabu Božju Doru Remebot (OP, 234).

Sudeći prema njegovim sopstvenim priznanjima, ovaj pjesnik nije se odrekao ljubavi zato što se razočarao u ženu, već i zbog toga što su ga ljubavna osjećanja iscrpljivala i egzistencijalno ugrožavala. 
Ja sam opazio, da nikada ne osjećam tako kao ljubeći...; ali da od ranjene ljubavi ne mogoh ni hodati, dakle da njena nesreća ne razboljevaše samo moje osjećanje, nego i moju misao... Ljubav sama, i ona baš najviše, pri samoj svojoj pojavi razdire čovjeka tjelesnom mukom i nelagodnošću, nekim nemirom što ne dozvoljava da se sjedi, da se stoji, da se leži, da se radi, no goni čovjeka po poljima, po livadama, po morima, daleko od sebe, u nemir što kida i lomi. A teško meni, ja sam pored svih užasnih kriza kojima je naše vrijeme obilovalo, ja sam pored i povrh svega toga bio ranjen u ljubavi. Popljuvan, išćuškan, premlaćen, izmučen, pedepsan i prebit u neprovredivoj, u neoskrvljenoj ljubavi, i to mi je donijelo patnje kakve se bojah da nije čovjek prije mene iskusio. (SD 1963-1966: VI, 260-261, 287-288)

Ovakve ljubavne patnje mučile su Ujevića u mladosti, kada mu je uzavrela duša bila obuzeta i drugim (političkim, moralnim i socijalnim) strastima i idealima. Kasnije, kada je sazrio, on mijenja mišljenje i o ljubavi i ženi, što se može zaključiti na temelju njegovih riječi:

Žene služe čemu i sve ostalo; spletkama, pa me već godinama nije ni u kakvom društvu... Ima u ženi toliko ružnih stvari koje su za prirodu sasvim dosljedne, ali ne za duh, jer upućuju na život. Zato bih i ženu htio zadržati samo u sferi duha, u iluzornoj sferi... ja prigovaram ženi ono što prigovaram i čovjeku; da je dio zoologije, bolje životinjske antroplologije, koja se nije prekalila u sekreciji suprematizma... Ljubav nije slobodna, ona je ropstvo po definiciji... Moja je primitivna filozofija bila: ima lijepih žena, krasotica, ovim treba pokloniti ljubav, voljeti ih. Kasnije sam promijenio: ljubav je bolest. (SD 1963-1966: XIV, 142; VI, 149-150; V, 83)

Žena je u njegovoj poeziji simbol sa širokim spektrom značenja. Kroz nju se posredno saopštava njegov odnos prema brojnim drugim problemima života. "I baš zato što se odnos prema ženi beskrajno komplikuje, jer implicira, u sferi potisnutosti i sublimacije, najkompleksnije odnose pesnika prema svetu, životu i sopstvenom biću" (Pavletić 1964: 13-14). Ona se javlja kao simbol, dio društva i individua, pa u njegovoj poeziji dolazi do izražaja simbolički, socijalni, individualno-psihološki položaj žene.

U mnogim pjesmama primjećujemo da Ujević samo u sferi duhovnog vidi mogućnost ljubavi. Zato pokušava da sve shvati duhovno, suprotstavljajući se tjelesnom. Ovako spiritualizovana vizija ljubavi je neostvariva, a samim tim i tragična, jer nijedna žena nije mogla da se saživi sa ulogom idealne žene: Božanska ženo, unuko visoke / pramajke Eve, pred tobom sam Adam, / $i$ jer te volim, ja od tebe bježim (OP, 108). A kad je on pokušavao da je spusti na zemlju, da je vidi i doživi kao plotsko, erotsko biće, tome se suprotstavljao njegov san o ženi kao čežnji, bogomajci i idealu ljubavi (Pavletić 1959: 413), jer kako pjesnik kaže: ti si ona za koju mene rodi majka (OP, 110), ali sve ćemo još doživjeti, sve osim ljubavne sreće, sve, osim srdačnih laži (SD, 145).

U njegovim stihovima iz kasnije faze stvaranja nalazimo religiozna raspoloženja, zagonetnost i dijaboličnost žene, za čijom se čednošću žudi i pored plotske žudnje. Jer ona je demon, strast, grijeh, pakao, pohota, simbol zla, pijanstvo misli i čula: ona je nagon nijemi požudan slasti slobode (OP, 231); ko hladna mana misao me rosi na njezin pokret (OP, 108); krvav demon želje, opsjela je Žena (OP, 229). Zato je novija lirika Ujevićeva obilježena ljubavnim jadom koji ništi sve oko sebe, jer ga izaziva pogibeljna žena - Kada danas, srušen, nemam porodice, / kad ne sreh na valu istinite ljube; / preklinjem te, reci, o Bogorodice, / čemu tvojem Sinu sve tragične trube? (OP, 80). Pjesnikov stav prema ženi nedvojbeno je promjenljiv - $\mathrm{u}$ 
stihovima iz kasnijeg perioda ljubav nije više magična, eros postaje znak zla, ona je čas Himera (pjesma Siromaški put), čas hijena i vampir (pjesma San uskrsava sablasti), čas groteskna utvara (̌̌enska spodoba što pleše po zici $\mathrm{SD}, 250$ ), čas prolazna i uzaludna (pjesma Ukleta djevojaštva). Zato se kao protivteža ovoj ženi, u njegovom duhu i poeziji javlja sveta žena koja je inkarnacija subjektivnog ideala ljepote, pa i religioznog apsuluta. Zahvaljujući tome, ljubavno osjećanje je sve manje čulno i spiritualno, a sve više mistično, zato ona postaje snoviđenje žene (OP, 98).

Zagonetni Ujević dok se oprašta sa ženom kao "velikom obmanom prirode", kao fantazijom Ti si ona koje nema, a ja sam onaj koji nije ovdje (SD, 64), nastavlja potragu za "Ženom idealnom" na jedan drugačiji način, pa pjeva meni se čini da je Svemir, ili Nirvana, ona prava Žena. / To je barem moja žena, moja zaštitnica. I Ne kažem paganski: Muza. (SD, 150). On je poistovjećuje sa svemirom, to je žena "novog kova", žena koja će postati "đerdan snova". Tako se slika žene iz slavne tradicije i kulturne povijesti seli u svemir budućnosti.

U mnogim njegovim pjesmama žena je mistificirana, nestvarna, viđena samo u pjesnikovim snovima. Ujevićeva ljubav je vrlo nejasna: ni plotska, ni čulna, ni idealistička. Plaši se žene kao obmane, pjesnik pati odričući se svega, zagledan narcisoidno u sebe. "Čeka se i moli i zove žena. Nestvarna, nevidljiva, žena iz sjećanja, žena iz vizija, žena u bunilu osama crtana po zidovima svijesti kao freska, nadzemaljske ljepote, čistoga tijela i duše. Žena - duh. Žena - ideja. Žena - religija stvaraočeva, spasiteljica, njegovateljica, žena - lijek od zla" (Goranović 2008: 304)

Ja te tako motrim kraj smeđih portala / kao neko biće iz Višega Svijeta (OP, 112); Možda te vidjeh u dalekoj slici / u kolutima tamjana i slavlja / ili na kakvoj taštoj razglednici (OP, 152); Njoj kojoj ne znam Imena, / sva hvala za moju luku u prostranom Hristu. (OP, 165).

To je žena viših sfera koja ne silazi na zemlju, i živi u čistim predjelima pjesničkog sna. Kada je vizije dozovu u pjesnikovu dušu, ona je ovdje da je osvijetli, da ozrači mističnu svečanost patnje, da bude čudesna kao kap svjetlosti u oku, tužni refren molitve, čuvar duše od grijehova zemaljskih, neizliječena ljepota i patnja koja rađa, čuva i brani jedan novi svijet. Ona je u ovim pjesmama mistična snaga koja pokreće čitav jedan svijet pjesničkih visina. Ona je sve, nepoznato, ljubav ljubavi, san sna, i više od toga:

Božanske žene, sve ljepote svijeta, / i lavska gordost i plahota srne, / kroz vaše čari uzvišene cvjeta / u plave dane, i u noći crne. / I kada stopom punom svetog mira / budite zemlji ritam svih otkrića, / slutim vas srcem plamenim svemira, / slutim i ištem tajnu vaših bića. / Božanske žene, što u snu i slavi / čekate zoru pravednih oltara, / pred vašim likom koljeno se savi / a srce, zvučni plamen, već izgara (OP, 48).

Tin bježi od tih slatkih varki i obmane jer ja te volim, ja od tebe bježim $(\mathrm{OP}, 108)$ i sanja o idealnoj ženi. Ipak, čim pomisli na senzualnost te žene, ponovo se vraća suzdržanosti i pita se šta ćemo mi pjesnici kad ne budemo voljeli žensko tijelo, I kad ne budemo dragali prirodu kao ženu (SD, 172).

U poznatoj pjesmi Molitva bogomajci za rabu Božju Doru Remebot Ujević spaja lik žene majke sa svojom vizijom Madone sa čijih je usana popio prve bajke. I u ljubavnim i u sinovskim osjećanjima Ujević je težio da senzibilnost prenese u sfere idealističke spiritualnosti, da u temama o ženi ispovijeda produhovljene 
svoje, u samoći ćelije proživljavane snove o veličini - čednosti i nevinosti ljudske prirode, koje nemilosrdno prlja ružna java. Zato je žena u Ujevićevim pjesmama “oganj duševnih emocija”. Pred njom je pjesnik i malen i nemoćan i slab, i velik i snažan, pred njom i moli i plače i žali se i otuđuje se, pred njom pada i vaskrsava, brižnog, svetačkog izgleda, ali ona je snaga i bura u pjesmi: snaga koja ruši samo sebe, koja lomi i satire (Goranović 2008: 305):

S krivom il s pravom - ridam: pašću, pašću / od jedne hijene što mi grudi kida, / od jedne žene s dušom i sa strašću. / Ona je ponos i gubitak vida, / a ja je žudim slašću ili čašću, / i ljubav nema koprene ni stida (SD, 55); Pred njenim likom da se skromno klekne / u slavu bola i u slavu snova / kao pred neki živi Jeruzalem. / I da se plače, i da se vjera rekne. / I svaki uzdah bude Vita Nuova, / A svaka suza dragi sjajni alem (OP, 38).

Mit i san o ženi, s jedne strane, i čvrsta realnost, s druge strane - put je kojim se pjesnik kreće. Tin piše u feljtonu Žena u dušinom ogledalu: "Naći višu ženu sa dubokim srcem bio bi ideal, ali je u životu sve puno ograničenja i traži odricanja" (SD, 1963-1966, 327). Nekada je u slikanju žene bio pravi racionalista, nekada strasni emocionalista, ponekad flegmatični posmatrač, pa i vizionar maštovitosti. A zapravo je bio sve, jer kako je sam jednom prilikom rekao "nosim u sebi više od jednog čovjeka" (SD 1963-1966, XIV, 38). Ta mnogostrukost se ispoljavala u njegovoj poeziji i viđenju žene u njoj.

\section{Zaključak}

Ujevićeva ljubavna poezija je kao more - obilato tajnama, bremenito iznenađenjima, ustalasalo vidljivim i nevidljivim strujanjima, čudesno u svim smjerovima. Uvijek se doživljava drugačije i ne iscrpljuje se.

Kao da se u njemu odvijao sukob mističara i pjesnika, pa je nastojao da pomoću jezika izmiri mistično i pjesničko nadahnuće. On je u jeziku tražio istovremeno sredstvo za izražavanje ljepote, ali i jemstvo da se sačuva od ljepote, koje se smrtno bojao. Slutio je da apsolutna ljepota, koju doziva jezikom svoje poezije, zahtijeva i apsolutno davanje, samoodricanje.

Idealnog čovjeka, pa i idealnu ljubav tražio je izvan sebe. U ljubavi tražio je smisao života, izlaz iz tuđine, samoće i očaja.

Stvarnost njegove ljubavi, njene čistoće i njene vrijednosti bila je sva u njemu... Čistoću žene on sam stvara i čuva... Tijelo je svemu tome davalo one oblike, one momente, koji su značili borbu, apstinenciju, odricanje... (Zorić 1962: 11).

Idealnu ženu tražio je u čitavom nizu žena. Žena je sintaza životnog i apsulutnog - ona je majka i sestra, i Bogomajka, i prinčipesa; ona je carstvo vila, majka ideala, svetkovina dlijetu i kistu, ona je ljubljeno dijete, ikona, san i bajka. Žena je bezimena, nepoznata i kao takva pjesnička opsesija. Ali žena je i neposredni referent koja je jezičkim sredstvima diskursa istaknuta u prvi plan. Ujević je posebnu pozornost poklanjao jezičkom oblikovanju lika žene. I semantički sadržaj valoriziranja žene, kao i lingvistička sredstva kojima se izražavaju su raznovrsni.

Pažljivije zagledanje u ženske figure u Ujevićevoj poeziji kao autonomnog entiteta u poetskom diskursu otkriva pjesnikove promjenljive stavove o ženama. 
Te žene su evoluirale od usnulih djeva, prinčipesa, preko moćnih boginja, do žene kao najranljivije individue, ali fatalne i mistične. Ako pogledamo dinamiku razvoja književnog modela u njegovoj poeziji, primjećujemo da taj model krase dva polariteta - apolonsko i dionizijsko, prošlost i sadašnjost, strast i majčinstvo. Taj dualitet se odslikava u ženi koja je istovremeno i krotka i zla, boginja i smrtnica.

Veličina Ujevićevog pjesničkog majstorsta nalazi se u činjenici da kompleksnu temu sagledavanja ženskog identiteta, koja se kreće od nevine do demonizovane žene, on ni na koji način ne nameće čitateljima kao kanon u svom pjesničkom diskursu. Pjesnik je samo afirmira i daje čitateljima da proniknu u nju i potraže odgovore na složena pitanja poimanja žene u njegovoj poeziji.

\section{IZVORI}

Tin UJEVIĆ, 1963-1966: Sabrana djela (sv. I-XVII). Ur. Dragutin Tadijanović. Zagreb: Znanje.

--, 1957: Odabrane pjesme. Ur. Gvido Tartalja. Beograd: Prosveta.

\section{BIBLIOGRAFIJA}

Dragomir GAJEVIĆ, 1988: Tin Ujević u jugoslovenskoj književnoj kritici. Zagreb: Grafički zavod Hrvatske.

Ivana DRENJANČEVIĆ, 2018: Ujevićeva Kolajna tekstualnih dugova. Književna smotra 189/3, 25-34.

Sang Hun KIM, 2016: Odjeci kultura Dalekog istoka u djelu Tina Ujevića. Književna smotra 48/1, 103-110.

Milivoje MARKOVIĆ, 1962: Zaverenik bola i lepote. Uvod u razmišljanja o poeziji Tina Ujevića. Putevi 5, 15-24.

Ljubisav MILOSAVLJEVIĆ, S. Valerija KLEM, 2008: Žene koje su menjale svet. Novi Sad: MK Panonia.

Vlatko PAVLETIĆ, 1959: Evokacija pred spomen-pločom Tina Ujevića. Izraz 11-12, 405-415.

- -, 1964: Srpski i hrvatski pisci XX veka. Beograd: Prosveta.

Mirko PETI, 1981: O jeziku Ujevićeva pjesništva. Croatica: prinosi proučavanju hrvatske književnosti 11/12, 219-246.

Ante SELAK, 1992: Pjesmom pjesniku (metodski ogledi o Ujevićevoj poeziji). Zagreb: Školske novine.

Ante STAMAĆ, 2004: Tin Ujević o stanju duha dvadesetih godina. Dani hrvatskoga kazališta 30/1, 75-84.

Zoran STARČEVIĆ, 1998: Lingvističko vrednovanje žene i struktura diskursa u poslovici i reklami. Srpski jezik 3, 409-425.

Ljiljana ŠARIĆ, 2007: Modernistička jezična svijest u Ujevićevom stvaralaštvu. Zadar: Croatica et Slavica Iadertina.

- -, 2006: Modernistički aspekti Ujevićević proznih zapisa: Montparnasse. Fluminensia $18 / 2,133-158$. 
Drago ŠIMUNDŽA, 1982: Odrazi vjere i nevjere u hrvatskoj književnosti: Tin Ujević vječno traženje Boga. Crkva u svijetu 17/3, 240-276.

Stjepko TEŽAK, 1981: Otkloni od književnojezičke norme u pjesničkom jeziku Tina Ujevića. Croatica: prinosi proučavanju hrvatske književnosti 11/12, 293-305.

Novo TOMIĆ, 1981: Apsulutna žena u poeziji Tina Ujevića. Osvrt na Kolajnu, Lelek sebra i Pjesničke proze. Croatica: prinosi proučavanju hrvatske književnosti 11/12, 307-321.

Pavle ZORIĆ, 1962: Kritički eseji. Titograd: Grafički zavod.

\section{OBLIKOVANJE ŽENSKE IDENTITETE V POEZIJI TINA UJEVIĆA}

Z ozirom na dosedanje nekoliko manj prisotno preučevanje Ujevićevega dela z jezikoslovnega vidika smo se v članku posvetili analizi ženske identitete, ki v širšem diskurzu osvetljuje številne posebnosti pesnikove vizije ženske. Nova prebiranja Ujevićevih besedil so namreč omogočila analizo strukture jezikovnega diskurza o ženski in tudi analizo jezikoslovnih sredstev, ki izražajo vrednostna stališča o njej. V delu smo identificirali, izdvojili, razvrstili in analizirali leksiko, ki se nanaša na koncept ženske. Ugotovljena je raznovrstnost tako na ravni semantične vsebine vrednotenja ženske kot tudi na ravni lingvističnih sredstev. Če preverimo dinamiko razvoja književnega modela v njegovi poeziji, opazimo, da ga določajo dvojnosti - apolonska in dionizijska, preteklost in sedanjost, strast in materinstvo. Vse to se odraža tudi v ženski, ki je hkrati prijazna in hudobna, boginja in smrtnica. Veličina Ujevićevega pesniškega mojstrstva pa se odraža $\mathrm{v}$ dejstvu, da avtor bralcu ne vsiljuje kompleksnih tem ženske identitete, ki segajo od nedolžne do demonizirane ženske. Pesnik bralcem omogoča vpogled vanje in jih spodbuja $\mathrm{k}$ iskanju odgovorov na kompleksna vprašanja zaznavanja ženske v njegovi poeziji. 


\title{
Projekt Etymologického slovniku české a slovenské vinohradnické a vinařské terminologie
}

\author{
Jana Villnow Komárková \\ Etymologické oddělení, Ústav pro jazyk český, v.v.i., Akademie věd ČR, Veveř́ 97, \\ CZ-60200Brno, jana.villnow@gmail.com
}

\begin{abstract}
1.01 Izvirni znanstveni članek - 1.01 Original Scientific Article
$\mathrm{V}$ prispevku je predstavljen raziskovalni projekt Jezik tradicionalnega vinogradništva in vinarstva $v$ srednjeevropskem prostoru: etimologija in arealno jezikoslovje ter njegov temeljni rezultat, tj. elektronski Etimološki slovar češke in slovaške vinogradniške ter vinarske terminologije. Gre za slovar manjšega obse$\mathrm{ga}, \mathrm{v}$ katerem je predstavljena etimologija in zgodovinski razvoj zbranih čeških (in primerjalno tudi slovaških) vinogradniških ter vinarskih terminov. Analiza čeških in slovaških besed je vključena v širši geografski okvir t. i. srednjeevropskega vinarskega prostora, zato so zajeti tudi ustrezni terminološki sistemi v nemščini (ali avstrijski nemščini), madžarščini, slovenščini, hrvaščini in poljščini.

This paper presents the research project The language of traditional viticulture and viniculture in the Central European area: etymology and areal linguistics as well as its main result - the electronic Etymological dictionary of the Czech and Slovak viticultural and vinicultural terminology. This is a small-scale dictionary, in which the collected Czech (and comparatively also Slovak) terms are etymologized and their development is described. The analysis of the Czech and Slovak words is implemented in a broader geographic context - the so-called Central European wine-growing area. The equivalent terminological systems of the neighbouring languages are researched - the German (respectively Austrian), Hungarian, Slovenian, Croatian and Polish.
\end{abstract}

Ključne besede: etimologija, češka in slovaška vinogradniška terminologija, češka in slovaška vinarska terminologija, srednjeevropski vinarski prostor, elektronski slovar

Key words: etymology, Czech and Slovak viticultural terminology, Czech and Slovak vinicultural terminology, Central European wine-growing area, electronic dictionary

\section{Úvod}

Víno jako jeden z nejstarších nápojů v dějinách lidstva stojí v centru zájmu nejen jeho konzumentů, ale také odborníků z řad enologů, archeologů, historiků, etnologů a v neposlední řadě lingvistů. Věda již dokáže zodpovědět otázky týkající se 
původu zpracování divoce rostoucí vinné révy do podoby oblíbeného alkoholického nápoje, stejně jako času a prostoru, v nichž došlo ke zušlechtění této rostliny. Existují podrobné popisy historie výroby vína $\mathrm{v}$ různých obdobích a na různých územích, obdobně také analýzy hospodářského významu vinařství či symboliky, jež se ve víně a vinné révě skrývá. Stále však zůstávají neprobádané oblasti, jež si zasluhují pozornost. Jednou z nich je odborné názvosloví spjaté s vinohradnictvím a vinařstvím a analýza jeho původu a historie v konkrétních jazycích, resp. jejich skupinách.

V následujícím př́spěvku bude prezentován výzkumný projekt „Jazyk tradičního vinohradnictví a vinařství ve středoevropském areálu: etymologie a areálová lingvistika", ${ }^{1}$ jehož hlavním výstupem je elektronický Etymologický slovník české a slovenské vinohradnické a vinařské terminologie. Jde o slovník menšího rozsahu zaměřený na českou (komparačně i slovenskou) vinohradnickou a vinařskou terminologii.

Pěstování kulturních odrůd vinné révy a produkce vína byly od počátku provázeny přeshraničními a mezijazykovými kontakty, což se projevilo v lexiku daného věcného okruhu. Po zohlednění tohoto aspektu se stal součástí výzkumu širší geografický celek - tzv. středoevropský vinařský areál - zahrnující vedle českého a slovenského jazykového prostoru také přilehlé oblasti německé (resp. rakouské), mad’arské a šířeji i slovinské, polské a chorvatské. Na tomto území docházelo po staletí $\mathrm{k}$ transportu enologických dovedností a $\mathrm{v}$ souvislosti s tím i $\mathrm{k}$ přejímání př́íslušné slovní zásoby.

\section{Analyzovaný materiál}

V rámci projektu je primárně zkoumána česká slovní zásoba z oblasti vinohradnictví a vinařství, jež byla nashromážděna na jedné straně excerpcí historických pramenů, lexikálních databází staré a střední češtiny ${ }^{2}$ a odborné dialektologické, enologické, etnologické a historické literatury, na druhé straně vlastním terénním výzkumem, který probíhal formou přímého dotazování u vinařů. Motivací $\mathrm{k}$ realizaci terénního výzkumu byla především skutečnost, že v Česku v minulosti podobně zaměřený dialektologický výzkum neproběhl (na rozdíl od Slovenska, srov. níže), a bylo tudíž nutné tento prostor pro potřeby výzkumného projektu zaplnit. Byl vypracován dotazník obsahující vedle základních dotazů na věk, původ a pohlaví respondenta, místo výzkumu, rozlohu vinic(e) a dobu, po niž se tázaný věnuje vinohradnictví/vinařství, 32 otázek z oblasti vinohradnictví, 26 otázek zaměřených na vinařství a 6 otázek ze sféry zvykosloví spojeného s pěstováním vinné révy a výrobou vína (celý dotazník viz Př́loha). Při volbě otázek se vycházelo z tematických okruhů ,vinná réva - odrůdy vinné révy, pěstování vinné révy, nemoci vinné révy“, „vinohrad“, „vinobraní a př́ibuzné činnosti“, „výroba vína“, „víno a jeho odrůdy“, „konzumace vína“ a „zvyky a tradice spojené s pěstováním

\footnotetext{
${ }^{1}$ Postdoktorský projekt Grantové agentury České republiky, r.č. 14-01768P.

${ }^{2}$ Vokabulář webový a jeho lexikální zdroje (dostupný na www.vokabular.ujc.cas.cz), Kartotéka excerpce ze staročeských textů (dostupná na www.bara.ujc.cas.cz) a Lexikální databáze humanistické a barokní češtiny (dostupná na www.madla.ujc.cas.cz).
} 
vinné révy, produkcí a konzumací vína“. Dotazníkový materiál byl zachycován písemně a zčásti - pokud k tomu respondenti dali souhlas - také formou zvukových nahrávek. Výzkum byl realizován ve vinařských oblastech na jižní Moravě, kde bylo zkompletováno 50 dotazníků.

Hlavním zdrojem slovenského lexikálního materiálu byla kartotéka Dialektologického oddělení Jazykovědného ústavu L'udovíta Štúra Slovenské akademie věd v Bratislavě. ${ }^{3} \mathrm{~V}$ ní se nachází dotazníky k tématu „,vinohradnictví“, shromážděné během terénního výzkumu realizovaného pod vedením Jozefa Nižnanského od 60. let 20. století ve vinařských regionech na jihu Slovenska (obsahují celkem 623 dotazů). Vedle tohoto zdroje byla excerpována dialektologická, etnografická a enologická literatura a získaný materiál byl ověřován ve výkladových, nářečních a historických slovnících. Zajímavým doplněním se z hlediska jazykového a kulturologického stala komparace s vývojem a současným stavem v tokajské vinařské oblasti na východě Slovenska, jež stála na rozdíl od oblastí jihoslovenských a jihomoravských v průběhu historie silněji pod vlivem mad’arským. Navíc zde vinařství ve středověku po tatarském vpádu nešířili Němci (viz dále), ale vinaři, již přišli z Itálie.

Významný podíl na rozvoji vinohradnictví a vinařství na jihu Moravy a jihozápadě Slovenska měli středověcí němečtí kolonisté. Ti s sebou přinesli nejenom nové výrobní postupy, ale spolu s nimi také odpovídající nomenklaturu, která zanechala stopy $\mathrm{v}$ historickém i současném lexiku češtiny a slovenštiny. $Z$ tohoto důvodu byl do projektu zahrnut také výzkum německé vinařské terminologie. Německý lexikální materiálu byl čerpán z jazykovědné, etnografické a enologické literatury a z internetového Slovníku německého vinařského jazyka („Wörterbuch der deutschen Winzersprache“). ${ }^{4}$ Obsahem tohoto slovníku, jenž vznikl jako projekt Akademie věd a literatury $\mathrm{v}$ Mohuči, je německá vinohradnická a vinařská terminologie užívaná nejenom na území německy mluvících zemí, ale také v bývalých německých jazykových ostrovech mj. v Česku a na Slovensku.

Mad’arština neměla ve srovnání s němčinou na vývoj české a slovenské vinohradnické a vinařské terminologie zásadní vliv (sama byla ovlivněna němčinou), přesto ji nebylo při analýze daného okruhu slovní zásoby ve zvoleném geografickém celku možné pominout. Materiál získaný excerpcí enologické a etnografické literatury byl primárně použit při etymologických výkladech jako zdroj, prŕípadně jako formální či sémantická paralela analyzovaných českých a slovenských termínů.

Podobným způsobem jako německé a mad’arské byly excerpovány také vinohradnické a vinařské termíny z dalších výše již zmíněných jazyků - chorvatštiny, slovinštiny a polštiny. Ty byly rovněž zakomponovány do relevantních etymologických interpretací českých a slovenských slov.

\footnotetext{
${ }^{3}$ Děkuji tímto pracovníkům oddělení, v první řadě jeho vedoucí Kataríne Ballekové, za umožnění práce s tímto cenným materiálem.

${ }^{4}$ Dostupný na adrese: www.winzersprache.de.
} 


\section{Metody}

Vinohradnické a vinařské termíny byly zkoumány $\mathrm{v}$ první řadě z hlediska 1) etymologického, kromě toho byla zohledněna hlediska 2) jazykově-zeměpisné a kontaktovělingvistické.

Ad 1) Etymologizace jednotlivých výrazů probíhala v souladu s trendy panujícími v moderní etymologii: důraz byl kladen na sémantickou stránku a na interdisciplinární pojetí. Z hlediska lexikální sémantiky byl zohledněn nejen samotný a) proces motivace pojmenování, ale pozornost byla nadto věnována b) sémantickým vztahům uvnitř daného věcného okruhu, především synonymii, resp. heteronymii, tj. mezinářeční synonymii. Ad a) Vedle případů, kdy byl daný termín utvořen primárně pro potřeby vinohradnické a vinařské terminologie (srov. v první řadě bázi dané terminologie představující pokračování psl. rekonstruktů - víno, vinohrad, vinice, vedle toho novější výrazy jako např̀. $d r t$,,rozdrcené hrozny před lisováním“, mlátovice „destilát z výliskư“, dial. presovňa „lisovna“; samostatnou kapitolu tvoří vlastní jména odrůd, převážně mezinárodního charakteru, motivována nejčastěji místem vzniku či šlechtitelem), sehrála při onomaziologickém procesu roli sémantická specializace (srov. např. č. bobule, slk. bobul'a „část hroznu“, č. bouda, slk. dial. búda „strážní objekt ve vinici“, č. a slk. brázda „mez oddělující vinice“, dužina „št’avnatá část hroznu“, č. fazoch „zálistek“), metafora (č. a slk. hlava „horní část vinné révy“, č. a slk. očko „část révového keře“, č. fazolka „,̌ást révového keře, očko“, č. holoubek „rozvíjející se očko na révovém keři“", č. vlk „neplodný vinný výhonek“) a metonymie (např. č. dřevo, slk. drevo „dřevnaté výhonky vinné révy“, č. noha „část vinařského lisu“, stč. les „,výhonek vinné révy“). Nadto došlo v některých případech $\mathrm{k}$ přejetí výrazu z př́ibuzné pivovarnické terminologie, jež vykazuje dle analyzovaných dokladů v češtině vyšší stáŕí než dané termíny vinařské, srov. např. břečka ,víno špatné kvality“ - původně „mladé, nevyzrálé a nezkvašené sladké pivo“, mláto „výlisky z hroznư“ - původně „,zbytky vylouhovaného sladu sloužící jako krmivo“, patok „podřadnější víno z výlisků a vody“ - původně (pl. patoky), ,pivo horší jakosti získané jako druhý odvar ze sladu“. Ad b) Synonymie, resp. heteronymie, je průvodním jevem především u slov teritoriálně př́iznakových. Lze se s ní setkat např. u výrazů s negativně hodnotícím rysem. Srov. synonymní řadu zahrnující pojmenování vína špatné kvality (materiál získaný terénním výzkumem): břečka, patok, slabé víno, nepitelné víno (,,nedá sa (to) pit“), zlomené víno, vadné víno, nemocné víno, zkažené víno, špatné víno, víno „,na hada“ (= na vypálení), čúčo, maták, pikule/pikula, pajdoš, pajdulák, pačkuda, šmejd, rit’’́k, šmatlák, humus, oxidačka, čekačka. Nebo blízké názvy matolinového vína, tj. vína $\mathrm{z}$ výlisků: čingir, druhák, grúl, vodnar, vodnář matolínové víno, padělák, pajdoš, patok, pikula, několikaterák, trhák, polovičák, hodnér. Kromě toho jsou doložena synonyma představující české ekvivalenty německých, většinou starších termínů, srov. nap̌r. kantýř, štelář (germanismy) - podsada, podkladek, podstavec ,podstavec pod sudy ve vinném sklepě“. Nebo dvojice perkmistr - horný „správce vinohradu“, perkrecht - horenské právo „dávka z vinic“, pres - lis, presovňa - lisovna apod.

Významným př́stupem je při výkladu původu slov z oblasti hmotné kultury interdisciplinarita. Týká se to především odborných výrazů příznakových časově 
či teritoriálně - tedy historismů, archaismů a dialektismů. Při jejich analýze je pro správnou etymologickou interpretaci nezbytná nejenom znalost zákonitostí jazykového vývoje, ale také poznatky z jiných oborů - historie, etnologie či technologie řemesla. Jako příklad lze uvést původ a vývoj českého názvu vinohradnického zvyku zaráženi hory, jímž se označuje slavnostní uzavírání vinohradu před začátkem vinobraní, přičemž hora je zde tyč představující hlavní atribut hotaře, hlídače vinohradu. Syntagma zaráženi hory je pozůstatkem nomenklatury tzv. horenských (viničních) práv, kde se horou (často s př́ivlastkem viničná) označovaly vinohrady ležící v jedné trati. Kořeny termínu hora je však nutné hledat už v antickém římském horenském právu, v jehož rámci se odpovídajícím latinským termínem mons označovaly nově založené vinohrady. Tento termín převzalo i středověké horenské právo ius montium, jak dokládá jeho výskyt v latinsky psaných dokumentech vztahujících se $\mathrm{k}$ vinohradnictví. $\mathrm{V}$ textech psaných národními jazyky se tento latinský termín překládal, a proto se českým označením vinohradu, resp. komplexu vinohradů ležících $\mathrm{v}$ jedné trati postupně stal výraz hora. Je přitom pravděpodobné, že zprostředkovatelskou roli zde sehrála němčina a že český vinohradnický a právnický termín hora byl utvořen pod vlivem německého pendantu (Wein)Berg. Poté, co byla horenská práva na Moravě v roce 1784 zrušena tzv. Všeobecným vinohorenským zřízením pro Markrabství Moravské Josefa II., ztratila hora svůj původní terminologický význam (dnes se místo toho užívá výraz trat') a zůstala zachována pouze jako součást názvu zvyku zaráženi hory (více k tématu viz Villnow Komárková 2014: 233-236).

Jiným př́kladem interdisciplinárního přístupu k etymologizaci slov je výklad původu českého názvu částečně zkvašeného hroznového moštu burčák (slk. burčiak, odtud mad'. burcsák „burčák“, „mladé víno“, Benkő 1997: 1639). S největší pravděpodobností se jedná o pojmenování motivované procesem výroby nápoje, tedy kvašením připomínajícím bouření. Potom by byl burčák odvozen od základu bur-, jenž je ve slovese bouřit (stč. búřiti, psl. buriti), jak uvádí Machek (1968: 77) a v souhlase s ním Rejzek (2015: 106); srov. k tomu německou (rakouskou) sémantickou paralelu Sturm tv., původně „bouře“ (jiný, méně pravděpodobný výklad navrhuje M. Štědroň, jenž slovo spojuje na základě dokladu z roku 1745 se slovesem brčeti „bručet, naříkat“ (burčák jako víno, které přri kvašení „brčí“, viz Štědron̆ 1995: 97-102).

Ad 2) V souvislosti s jazykově-zeměpisným a kontaktovělingvistickým pojetím představuje samostatnou kapitolu projektu analýza výpůjček, z převážné části germanismů. Jak již bylo uvedeno výše, bylo české a slovenské vinohradnictví a vinařství od středověku silně ovlivňováno vinohradnictvím a vinařstvím německým, resp. rakouským, což se projevilo také v názvosloví daných oborů lidské činnosti. Výpůjčky z němčiny proto představují významnou součást analyzovaného materiálu. Tak např́iklad samotné slovo víno, které je kulturním slovem vypůjčeným z latiny (lat. vīnum), bylo do praslovanštiny podle jedné teorie přejato germánským prostřednictvím. Jako jazykový útvar, který toto přejetí zprostředkoval, prritom připadá do úvahy bud' gótština (gót. wein), anebo stará horní němčina (sthn. wīn). Jako další př́iklad starých germánsko-slovanských jazykových kontaktů lze uvést všeslovanský výraz vinohrad, rekonstruovaný do praslovanštiny jako *vinogordz. $\mathrm{S}$ velkou pravděpodobností se jedná o výpůjčku gótského weinagards, „vinice, 
vinohrad“, které má doložené protějšky i v jiných germánských jazycích, srov. mj. německé Weingarten či niz. wijngaard „vinohrad“ (Feist 1923, 426: Kiparsky 1934: 224f, Hamm 1942: 123f, Vasmer 1: 202, Shevelov 1964: 415, Siatkowski 1965: 193n, Lehmann 400, Gołąb 1992: 378, Pronk-Tiethoff 2013: 127 aj.). (Předpoklad o germánském zdroji přejetí však není v etymologii přijímán všeobecně, někdy se pomýšlí na domácí složeninu s první částí *vino, druhým komponentem *gords „ohrazené, oplocené místo“a původním významem „vinnou révou osázené ohrazené místo“ $\rightarrow$ „vinice, vinohrad“ (Skok 3: 595, Černych 1993, 1: 152, Snoj in: Bezlaj 4: 320, Snoj 2016). Konečně se někdy uvažuje o slovotvorném kalku germánského slova, tak Sadnik-Aitzetmüller 1955: č. 1082, Šanskij 1963: 101, Mel’nyčuk 1982: 377f). Podrobněji viz Janyšková 2016: 1063-1064.

K mladším českým výpůjčkám z němčiny náleží další vinařský termín tvořící i dnes bázi daného úseku slovní zásoby. Jedná se o slovo réva „vinná réva“" (slk. st. a dial. réva, rév, srov. také dl. st. rewa tv., viz Muka 1928: 306), doložené $\mathrm{v}$ češtině od začátku 15. století, které je výpůjčkou středohornoněmeckého rëbe (něm. Rebe). Německé slovo má svůj původ v ie. *rep- „plazit, popínat“, a jeho motivace pojmenování je založena na způsobu růstu úponků vinné révy (Machek 1968: 513, Newerkla 2011: 209). K dalším starým českým vinařským termínům německého původu, které se dodnes užívají, patří např. označení násosky k nabírání vína ze sudu koštýr̆, ve staré češtině koštér (slk. st. a dial. koštier, koštúr). Jedná se o výpůjčku střhn. (wīn)koster, které původně označovalo osobu ochutnávající nějaký nápoj (především víno či pivo) a poté přeneseně nástroj $\mathrm{k}$ tomu užívaný. V obou významech bylo slovo přejato do češtiny. Německé slovo má svůj původ v pragermánském základu *kus-tō s významem ,(vy)zkoušet“ (Kluge 2002: 531).

Stopy zanechala němčina také v oblasti českého vinohradnického a vinařského práva. Nejlépe to dokládá terminologie horenského práva, které od středověku regulovalo práva a povinnosti majitelů vinic. Horenské právo se ve staré češtině označovalo termínem německého původu perkrecht (/pergrecht), doloženým ve staročeských památkách od 14. století (srov. i slk. st. peregrecht tv., s podobným významem stp. barkracht, bargracht, bargrecht, bergrecht, berkracht „daňový př́ijem z dolu“ (Urbańczyk 1953: 67)) - složenina bavorského slova s částmi perg „hora“ a recht „právo“ (Newerkla 2011: 325). Německého původu jsou i některé další termíny z oblasti horenského práva, např. staročeské perknos „držitel vinice ve společném viničném obvodu s jinými“" (zřejmě také z bavorštiny, srov. střhn. bërcgenōz(e) „majitel vinohradu“) či perkmistr „úředník spravující daný viničný obvod a pečující o dodržování horenského práva“ (tvořeno výpůjčkou bavor. pęrk ${ }_{x}$, pęrg-, bęarg- „hora“ (zde označení viniční trati) a spojením se stč. mistr, jež je z lat. magister).

K dalšímu přejímání německých výrazů docházelo i v pozdějších obdobích, a že jsou kontakty na této úrovni aktivní i dnes, potvrzují nové germanismy získané terénním výzkumem. Často se jedná o slova, která náleží nářečním útvarům, a jsou tedy omezena teritoriálně. Patří sem mj. počeštěné názvy některých odrůd vinné révy, např. cinifandl, cinyfádl „sylvánské zelené“, jež vzniklo smíšením názvu odrůdy Zierfandler původem z Dolního Rakouska s názvem Zinfandel „odrůda červeného vína původem z Chorvatska“; jako Zierfandler se sylvánské zelené chybně označuje někdy i v Rakousku (Newerkla 2012: 317-318). K dalším lidovým 
názvům odrůd lze zařadit cvajglt „Zweigeltrebe“ (odrůda vyšlechtěna v roce 1922 v rakouském Klosterneuburgu), dolfa či dorn „Dornfelder“ (odrůda vyšlechtěna v roce 1955 v Německu) nebo milerka „Müller Thurgau“ (bílí moštová odrůda vyšlechtěná prof. Müllerem původem ze švýcarského kantonu Thurgau, jenž prováděl šlechtění v německém Geisenheimu). V němčině mají původ také nářeční označení vinného střiku (vajn)špric, svařeného vína glivajn, anebo burčáku šturm. Výrazy pančovat, pančované (víno), pančování jsou z něm. hovor. panschen, pantschen „falšovat víno vodou“ (což zřejmě souvisí se slovesem patschen „tleskat, pleskat“, snad podle negativně hodnoceného nepatřičného zacházení s vínem, srov. Machek 1968: 432, Kluge 2002: 678).

V daleko menší míře než germanismy jsou v nashromážděné materiálové bázi obsaženy výpůjčky z jiných jazyků: latiny - víno (pokud nebylo přejato př́imo z latiny, potom germ. prostřednictvím, srov. výše), mad'arštiny - č. dial. aldamášs, slk. st. a dial. oldomáš „,hostina po dokončení stavby vinného sklepa“, č. dial. čingir, slk. dial. čingír „víno horší kvality, druhák“ (do mad’arštiny přejato asi z nějakého turkického jazyka), či francouzštiny - č. a slk. cuvée „víno smíchané z více odrůd“, č. degustace, slk. degustácia „ochutnávka vína“, č. a slk. demižón „nádoba na víno“ (angl. prostřednictvím), č. dial. pipeta „násoska na víno“.

\section{Slovník}

Slovník je vytvářen v internetovém nástroji na psaní a publikování elektronických slovníků Lexonomy (viz Měchura 2017) a je př́stupný na adrese www.lexonomy. eu/vino. Jeho součástí jsou vedle samotné heslové části uvedení do tématu a různé indexy (o těch více níže).

\section{Struktura hesel:}

Heslové záhlaví obsahuje české slovo v jeho reprezentativní podobě a generuje se systémem Lexonomy automaticky podle prvního zmíněného českého slova $\mathrm{v}$ hesle. Poté následuje výčet všech tvarů, které se v češtině podařilo nalézt, opatřený stylistickou charakteristikou (tj. informací, zda se jedná o dialektismus, archaismus, historismus; v případě spisovného slova zůstává bez komentáře). Dalším údajem je uvedení historických forem slova (někdy s exemplifikací) a - pokud se podařilo zjistit - nejstaršího doloženého výskytu s datací. Další oddíl hesla představuje slovenský ekvivalent českého výrazu, resp. jeho nářeční a historické varianty, opět s uvedením datace nejstaršího výskytu, je-li znám. Jestliže mají české (a slovenské) výrazy protějšky i v jiných, nejen slovanských jazycích, jsou uvedeny v následujícím výčtu. Další část slovníkového hesla tvoří etymologický výklad, zahrnující rekonstrukci formálního a sémantického vývoje slova, určení jeho praformy a uvedení paralel z prŕibuzných jazyků. Dále je pozornost věnována výkladu sémantického vývoje slova a heslo je ukončeno výčtem synonym (jsou-li známá).

Uživatel může slovníkem navigovat pomocí abecedního seznamu hesel nebo může vyhledat libovolný text. Vyhledávací funkce prohledává nejen záhlaví hesel, ale i všechny ekvivalenty a synonyma. Proto lze ve slovníku vyhledávat i podle slov, která nejsou záhlavím žádného hesla, ale jsou uvnitř hesla zmíněna; např́íklad vyhledáním sln. dial. slova gantar se najde heslo kantýr̆, protože gantar je v hesle 
uvedeno jako jeho slovinský ekvivalent. Všechny zmíněné protějšky a synonyma jsou k dispozici i v podobě abecedního indexu.

Odkazy na literaturu a různé zkratky (většinou označení jazyků) jsou v textu slovníku zakódovány tak, aby se najetím ukazatele myši zobrazil jejich plný význam. Veškerou použitou literaturu a všechny použité zkratky lze prohlížet i v abecedních indexech a kliknutím na ně získat seznam hesel, ve kterých se na ně odkazuje.

\section{Ukázková hesla 5}

\section{čingir}

ČESKY dial. čingir 'víno horší kvality, druhák'

SLOVENSKY dial. čingír 'podřadné víno z výlisků', 'hroznový mošt začínající kvasit, burčák' (SSN 1, 263, 1), doklady od 17. stol. (HSSJ 1, 216)

OSTATNÍ JAZYKY srov. také ch. (kajk.) či(n)ger 'víno špatné kvality z výlisků' (Sokolić 1998, 74), sln. dial. čiger tv.

ETYMOLOGIE výpůjčka mad'. csiger 'podřadné víno z výlisků' (odtud je i rum. dial. cighir), což je asi z nějakého turkického jazyka, snad tur. čakyr 'víno' (Vasmer 3, 344, Skok 1, 323, Bezlaj 1, 81, EWU 1, 210-211, Rocchi 1, 70); z mad'. bylo přejato také něm. dial. Tschiger, Tschigerwein 'matolinové víno' (WDW)

SYNONYMA druhák, grúl, vodnar, vodnár, matolínové vino, padělák, pajdoš, patok, pikula, několikaterák, trhák, dvojchlapový víno, trojchlapový víno, polovičák, hodnér

\section{dužina}

ČESKY dužina, dužnina 'štavnatá část hroznu'

ETYMOLOGIE dužina, dužnina 'masitá, štavnatá část ovoce' je pouze český výraz bez protějšků v jiných slovanských jazycích; doklady od 19. stol. (u Presla ve významu 'dužnatá část rostlin', viz Jg. 1, 514); odvozuje se od st. adjektiva duží, dužný 'velký', 'silný, masitý' (srov. střč. dužný 'masitý, libový' (VelDict, viz LDHBČ, cit. stav z 28.4. 2019), př́ibuzné je pol. dużi 'velký', $r$. dial. dúżij 'silný'), které náleží k rodině psl. adj. *dogъ 'silný, masitý' (se záporkou ne je $p s l$. *nedogъ, č. neduh 'nemoc, neduh'), odvozovaného od slovesa *dęgnoti 'růst, sílit' a dále snad od ie. kořene *dheugh- 'hodit se, být zdatný' (Machek 1968, 394, ESJS 9, 534n, Rejzek 2015, 163 a Rejzek 2015, 447).

SÉMANTICKÝ VÝVOJ význam ‘štavnatá část hroznu' vznikl sémantickou specializací významu 'štavnatá část ovoce’

\section{mláto}

ČESKY mláto 'výlisky z hroznů', od 16. stol. (srov. např. ,„pól druhého dielu mlata z pressu vinného...", Raimund Lullius: Praktika testamentu (z r. 1500), viz StčE, cit. stav z 28.4.2019), stč. 'zbytky vylouhovaného sladu sloužící jako krmivo' - od 14. stol. (srov. Klaret, Bohemář, verš 698, in: Flajšhans 1, 63)

SLOVENSKY mláto 'výlisky z hroznů' (SSN 2, 172), st. 'vylouhovaný slad nebo vylisované hrozny používané jako krmivo’ (HSSJ 2, 311), doloženo od 17. stol.

\footnotetext{
${ }^{5}$ Zkratky literatury a jazyků použité ve slovníku nejsou rozepsány v seznamu níže. Prosím čtenáře o nahlédnutí do elektronického slovníku.
} 
OSTATNÍ JAZYKY stp. a pol. st. mtoto 'mláto', 'zbytky sladu sloužící jako krmivo' (SStp 4, 296, Karłowicz 3, 174n), srb. a ch. dial. mlât, mlato 'výlisky z hroznů' (RSAN 7, 705, 710), mláta 'ječmen určený k vaření piva, slad', sln. dial. mláto, mláta 'mláto, slad' (Pleteršnik 1, 585), ukr. mólot 'sedlina v pivu' apod.

ETYMOLOGIE etymologie ne zcela jasná; uvažuje se bud' o staré výpůjčce germ. *malta 'slad' (srov. něm. Malz tv.), které náleží ie. *melt- 'tát, měkčit, rozpouštět' (Pokorny 718, Vasmer 2, 644, Rejzek 2015, 422 aj.), nebo o domácím původu slova, jež bylo odvozeno od kořene *mel- 'mlít' (Brückner 341, Skok 2, 441 aj.; srov. také Machek 1968, 368, SM 19, 196, Králik 2015, 363)

SÉMANTICKÝ VÝVOJ význam 'výlisky z hroznů’ vznikl dle všeho přenesením původnějšího významu 'zbytky sladu', došlo tedy k výpůjčce slova z jednoho řemeslného názvoslovného systému do jiného (pivovarnictví $\rightarrow$ vinařství)

SYNONYMA výlisky, matoliny

\section{putna}

ČESKY putna 'větší koš nošený na zádech při vinobraní', dem. putýnka 'menší koš při vinobraní' (Šebestová, 262) - od 14./15. stol. (srov.: ,putny, koše, štrokvasy, sudy a jiné stroje... at' jsou připraveny ke sbírání vína“ (Cresc, 186, cit. podle LDHBČ, stav z 27.4.2019)

SLOVENSKY putňa tv. - od 17. stol. (HSSJ 4, 576)

OSTATNÍ JAZYKY srov. pol. dial. putnia 'škopek na vodu' (Karłowicz 4, 456), ukr. dial. pútňa 'nádoba na vodu, mléko apod.' (přejato zřejmě polským prostřednictvím, ESUkr 4, 641)

ETYMOLOGIE výpůjčka bav. puttn 'kád', džber', srov. něm. Bütte, střhn. büt(t)e, büten, sthn. butin, butin(n)a 'kád', sud', jež je ze střlat. butina 'kád" (to z řečtiny, srov. Kluge-Seebold 2002, 164) - slovo bylo zřejmě přejato Germány v rýnsko-římských vinařských oblastech (Alanne 1980, 135); německého (bavorsko-rakouského) původu je také mad'. puttony 'koš nošený na zádech' (EWU 5, 1220). Srov. něm. dial. Butte 'nádoba na vinné hrozny nošená na zádech při vinobraní, uskladněná ve vinohradnickém domku apod.' (WDW)

\section{vincúr}

ČESKY dial. vincúr 'brouk zobonoska (škůdce na révě)', st. vincour 'vinař' (Šebestová, 264) - stč. vincéřr 'vinař', 'správce vinice', doloženo v mamotrektech z 15 . století (StčE, cit. stav z 28.4.2019), vedle toho i stč. vincúr 'vinař' (ESSČ bez udání zdroje, cit. stav z 9.1.2018)

SLOVENSKY dial. vincúr, vinclur 'vinohradnický dělník', 'vinař, 'brouk zobonoska' (SSJ 5, 100), st. i vincler, vincelír 'vinohradník' - ve významu 'vinař' od 17. stol. (HSSJ 6, 377)

OSTATNÍ JAZYKY srov. také sln. dial. víncar 'vinař' (Pleteršnik 2, 762)

ETYMOLOGIE výpůjčka střhn. wīnzer, wīnzürl (sthn. wīnzuril) 'vinař, vinohradník', jež bylo přejato z lat. vinnitor tv. (Newerkla 2011, 236n, Králik 2015, 660).

Předpokládá se přitom, že střhn. winzer, jež je ve starších textech doloženo řídce a prosazuje se více až od 17. století, vzniklo zkrácením formy winzzürl (Alanne 1950, 184n); srov. také mad'. vincellér 'vinař', 'druh škůdce na vinné révě' (odtud ch. dial. (kajk.) vincilîr a rum. vinţeler 'vinař', Skok 3, 594), přejaté rovněž z něm. (EWU 3, 1639)

SÉMANTICKÝ VÝVOJ význam 'brouk zobonoska' vznikl pravděpodobně jako ironické označení škůdce na vinné révě podle vinaře (Machek 1968, 690) 


\section{Závěr}

$\mathrm{V}$ př́spěvku byl představen projekt „Jazyk tradičního vinohradnictvi a vinařstvi ve středoevropském areálu: etymologie a areálová lingvistika" a elektronický Etymologický slovník české a slovenské vinohradnické a vinařské terminologie, který je jeho výstupem. Slovník je primárně určen lingvistům, především historikům jazyka a dialektologům, jež v něm mohou nalézt data relevantní pro svůj výzkum. Může však posloužit také odborníkům z jiných vědních oborů, historikům, etnologům a samozřejmě i enologům a samotným vinařům.

Slovník obsahuje materiál získaný excerpcí pramenů a literatury a vlastním terénním výzkumem, díky němuž byla do výzkumu zahrnuta i řada jinde nezaznamenaných českých výrazů. Doložení všech analyzovaných slov bylo ověřováno v historických zdrojích s cílem nalézt pokud možno jejich nejstarší výskyt. To umožnily především elektronické databáze staré a střední češtiny, jež jsou významným pomocníkem při etymologizaci českých slov. Pro ilustraci a zasazení do kontextu jsou vybrané starší české výrazy opatřeny exemplifikací s uvedením zdroje. Hlavní částí slovníku je etymologizace nashromážděných českých (a slovenských) výrazů z oblasti vinohradnictví a vinařství, zahrnující určení výchozí praformy, resp. zdroje přejetí, a výklad jejich formálního a sémantického vývoje. Vedle původu slov byl zjištován také jejich další vývoj a stav v současném jazyce vinařu. České (a slovenské) vinohradnické a vinařské termíny nebyly zkoumány izolovaně. Jejich vývoj byl sledován v širším areálovém kontextu, zahrnujícím vývoj terminologických systémů daného věcného okruhu v jazycích blízkých češtině (a slovenštině) geograficky, tedy němčině, mad'arštině, polštině, slovinštině a chorvatštině.

Lexikální zdroje přístupné na internetu mají jak známo oproti svým knižním protějškům jednu velkou výhodu - nejsou definitivním dílem. Lze je doplňovat, opravovat, reagovat na připomínky, vést se čtenáři dialog. To má v úmyslu i autorka tohoto textu, která slovník vzhledem k dosud neprobádanému lexikálnímu bohatství české a slovenské vinohradnické a vinařské terminologie a absenci jeho etymologického zkoumání zdaleka nepovažuje za uzavřený projekt a plánuje ho dále rozšiřrovat.

\section{LITERATURA}

Loránd BENKÖ (red.), 1997: Etymologisches Wörterbuch des Ungarischen 3. Budapest: Akadémiai Kiadó.

France BEZLAJ, 1976-2007: Etimološki slovar slovenskega jezika 1-5. Od 3. sv. Marko Snoj a Metka Furlan. Ljubljana: Inštitut za slovenski jezik Frana Ramovša.

Pavel Ja. ČERNYCH, 1993: Istoriko-etimologičeskij slovar' sovremennogo russkogo jazyka 1-2. Moskva: Russkij jazyk.

Sigmund FEIST, 1923: Etymologisches Wörterbuch der gotischen Sprache. Zweite, gänzlich neubearbeitete Auflage. Halle: Niemeyer.

Zbigniew GOŁĄB, 1992: The Origins of the Slavs. A Linguist's View. Columbus 1992: Slavica Publishers. 
Josip HAMM, 1942: Über den gotischen Einfluß auf die altkirchenslavische Bibelübersetzung. Zeitschrift für vergleichende Sprachforschung auf dem Gebiete der indogermanischen Sprachen 67, 112-128.

Ilona JANYŠKOVÁ (red.), 2016: Etymologický slovník jazyka staroslověnského 18. Brno: Tribun EU.

Valentin KIPARSKY, 1934: Die gemeinslavischen Lehnwörter aus dem Germanischen. Helsinki: Suomalainen Tiedeakatemia.

Friedrich KLUGE, 2002: Etymologisches Wörterbuch der deutschen Sprache. Bearbeitet von Elmar Seebold. 24. Auflage. Berlin, New York 2002: De Gruyter.

Winfred LEHMANN, 1986: A Gothic Etymological Dictionary. Leiden: Brill.

Václav MACHEK, 1968: Etymologický slovník jazyka českého. Druhé, opravené a doplněné vydání. Praha: Academia.

Michal B. MĚCHURA, 2017: Introducing Lexonomy: an open-source dictionary writing and publishing system. Electronic Lexicography in the 21st Century: Lexicography from Scratch. Proceedings of the eLex 2017 conference, September 2017, Leiden, The Netherlands. Dostupné online: www.lexonomy.eu.

Oleksandr S. MEL'NYČUK (red.), 1982: Etymolohičnyj slovnyk ukrajins'koji movy 1. Kyjiv: Naukova dumka.

Ernst MUKA, 1928: Stownik dolnoserbskeje rěcy a jeje narěcow 3. Petěrburg 1915, přetisk. Praha: Česká akademie věd a umění.

Stefan Michael NEWERKLA, 2011: Sprachkontakte Deutsch - Tschechisch - Slowakisch. Wörterbuch der deutschen Lehnwörter im Tschechischen und Slowakischen: historische Entwicklung, Beleglage, bisherige und neue Deutungen. Zweite, durchgehend überarbeitete und aktualisierte Auflage. Frankfurt am Main et al.: Lang.

- -, 2012: Pischinger, Zierfandler, Kaisersemmel und Zuckerkandl: Altösterreich als kulinarisches Sprachareal. Linguistica culinaria. Festgabe für Heinz-Dieter Pohl zum 70. Geburtstag. Ed. Hubert Bergmann und Regina Maria Unterguggenberger. Wien: Praesens Verlag. 309-323.

Saskia PRONK-TIETHOFF, 2013: The Germanic loanwords in Proto-Slavic. Amsterdam, New York: Rodopi.

Jiří REJZEK, 2015: Český etymologický slovnik. Nové, upravené a rozšířené vydání. Praha: Leda.

Linda SADNIK, Rudolf AITZETMÜLLER, 1955: Handwörterbuch zu den altkirchenslavischen Texten. Heidelberg: Carl Winter Universitätsverlag.

George Y. SHEVELOV, 1964: A Prehistory of Slavic. Heidelberg: Winter.

Janusz SIATKOWSKI, 1965: Bohemizmy fonetyczne w języku polskim. Cz. I. Wroclaw: Zaklad narodowy im. Ossolińskich.

Petar SKOK, 1971-1974: Etimologijski rječnik hrvatskoga ili srpskoga jezika 1-4. Zagreb: Jugoslavenska akademija znanosti i umjetnosti.

Marko SNOJ, 2016: Slovenski etimološki slovar. 3. izdaja. Ljubljana. E-kniha dostupná na: www.fran.si.

Nikolaj M. ŠANSKIJ et al., 1963: Etimologičeskij slovar' russkogo jazyka 1/3. Moskva: Izdatel'stvo Moskovskogo universiteta.

Miloš ŠTĚDROŇ, 1995: Výskyt slova burčák v německo-latinském studentském zpěvníku z Brna. Pocta Dušanu Šlosarovi. Boskovice: Albert. 97-102. 
Stanisław URBAŃCZYK (red.), 1953: Stownik staropolski 1. Wrocław: Zakład narodowy im. Ossolińskich.

Max VASMER, 1953-1958: Russisches etymologisches Wörterbuch 1-3. Heidelberg: Carl Winter Universitätsverlag.

Jana VILLNOW KOMÁRKOVÁ, 2014: Weinbau- und Winzerterminologie als Reflex der Sprachkontakte in der Habsburgermonarchie. Deutsch und die Umgangssprachen der Habsburgermonarchie. Ed. E. Cwanek-Florek und I. Nöbauer. Wien: Wissenschaftliches Zentrum der Polnischen Akademie der Wissenschaften. 229-236.

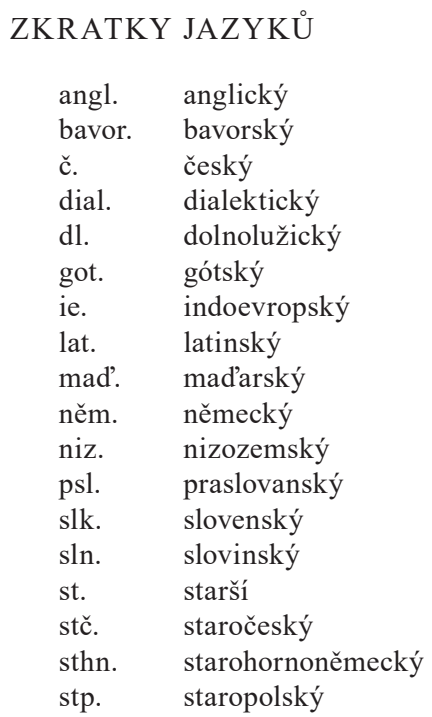

\section{PŘÍLOHA}

\section{dotazník „Terminologie jihomoravského vinohradnictví a vinařství“}

Místo výzkumu (obec / město, okres):

Vinařská oblast a podoblast:

Jméno:

Věk:

Pohlaví:

Zaměstnání:

Původ (starousedlík / novousedlík):

Rozloha vinic:

Doba, po kterou se respondent věnuje vinohradnictví/vinařství:

Explorátor/-ka:

Datum výzkumu:

\section{A. Vinohradnictví}

1. Jak se označuje pozemek se souvislou výsadbou keřů vinné révy?

2. Pocitujete rozdíl mezi významy výrazů vinice a vinohrad (event. hora)? Pokud ano, jaký?

3. Jak se označuje neobdělávaná vinice / vinohrad? 
4. Uved’te názvy viničních tratí, na nichž pěstujete vinnou révu.

5. Jak se říká příkopu, který od sebe odděluje vinohrady ležící v jedné viniční trati?

6. Jak se označuje prostor mezi řádky vinohradu?

7. Jak se říká procesu prokypření půdy před založením vinohradu/vinice?

8. Užíváte zvláštní označení sazenic vinné révy?

9. Jak říkáte révovému keři?

10. Pojmenujte na základě obrázku části révového keře:

11. Jak se označuje jednoletý vyzrálý zdřevnatělý prýt (stonek s listy) vinné révy po opadu listů?

12. Jak se označuje vytékání mízy z řezných ran révového keře?

13. Jakým termínem se označují postranní zelené letorosty révového keře, které se v létě vylamují?

14. Jak se označuje jednoleté dřevo, které je během řezání suché?

15. Jak se označuje proces zkracování zelených konců letorostů, které probíhá koncem léta?

16. Jak označujete zálistkové hrozny?

17. Jak se jmenuje řezáním/stříháním zkrácený letorost?

18. Pojmenujte podle obrázků části hroznu a bobule:

19. Jak označujete rozvíjející se očko na révovém keři?

20. Jak označujete neplodný vinný výhonek?

21. Jak se ř́́ká raným odrůdám révy?

22. Jak se označují hrozny zapomenuté po sklizni ve vinice / vinohradě?

23. Jaké odrůdy révy vinné pěstujete?

24. Jak se označuje jarní okopávání vinice / vinohradu?

25. Jak se jmenuje strážní objekt ve vinici / vinohradu?

26. Víte, jak se v minulosti označoval strážce vinice / vinohradu?

27. Jaké škůdce vinné révy znáte?

28. Jaké nemoci vinné révy znáte?

29. Jak se označují sběrné nádoby na hrozny při vinobraní?

30. Jak se označují (/označovaly) zádové putny na hrozny při vinobraní?

31. Jak ř́́káte zloději hroznů?

32. Jak se nazývá odstranění keřů vinné révy z pozemku?

\section{B. Vinařství}

1. Jak se označuje proces zpracování hroznů na drt' (drcení hroznů před lisováním)?

2. Jak se označuje místnost/budova, kde se lisují hrozny? Víte, jak se jí ř́íkalo v minulosti?

3. Jak se jmenuje typ lisu, který užíváte? Z jakých částí se skládá?

4. Jak se říká výliskům $\mathrm{z}$ hroznů?

5. Jak se nazývají nádoby ke skladování vína?

6. Jaké typy sudů užíváte?

7. Jak se označuje podstavec pod sudy ve sklepích?

8. Jak se říká podřadnějšímu vínu $\mathrm{z}$ výlisků a vody?

9. Jak se označuje mošt, který začíná kvasit?

10. Jak se označuje mošt po vykvašení?

11. Jak se ř́íá vínu špatné kvality?

12. Jak se jmenuje víno s přidaným nepovoleným cukrem, vodou nebo jinými látkami?

13. Jak se označuje ochutnávání vína?

14. Jak se rríká procesu hodnocení vína?

15. Jak se nazývá násoska k odebrání vína ze sudu? 
16. Jak ř́íkáte růžovému vínu?

17. Jak označujete vinný střik?

18. Jak se označuje víno vzniklé smícháním více odrůd?

19. Jaké chutové vady vína znáte?

20. Jak označujete velmi chutné víno?

21. Jaké se říká šumivému vínu?

22. Jak označujete víno, které Vám nechutná?

23. Jak označujete zapáchající víno? Po čem toto víno zapáchá?

24. Jak se říká př́ímému prodeji vína vinařem spotřebiteli?

25. Jaké označení se užívá pro nemocné víno se změněnou barvou nebo chutí?

26. K uvedeným oficiálním názvům odrůd uved’te jejich nespisovné varianty, pokud je sami užíváte:

bílé odrůdy:

červené odrůdy:

Veltlínské zelené - $\quad$ Burgundské modré -

Sylvánské zelené - $\quad$ Frankovka modrá -

Sauvignon -

Dornfelder -

Ryzlink rýnský -

Merlot -

Ryzlink vlašský -

Portugalské modré -

Veltlínské červené -

Cabernet Sauvignon -

Chardonnay -

Cabernet Moravia -

Müller Thurgau -

Svatovavřinecké -

Rulandské bílé -

Zweigeltrebe -

Rulandské šedé jiné:

Rulandské modré jiné

\section{Zvyky a tradice spojené s vinohradnictvím, vinařstvím a konzumací vína}

1. Jak se ř́iká slavnostnímu zavírání vinohradu v srpnu po svátku sv. Vavřince? (10.8.) spojenému se zákazem vstupu do vinohradu?

2. Jak se nazývá hostina oslavující postavení vinného sklepa?

3. Znáte zvyk označovaný jako „vinohradní kozel“/ „vinohradní koza“? Pokud ano, popište jej.

4. Uved’te pranostiky spojené s pěstováním vinné révy, výrobou a pitím vína. Př́i jaké př́iležitosti se užívají (/užívaly)?

5. Uved’te pořekadla či přirovnání apod. spojená s pěstováním vinné révy, výrobou a pitím vína. Při jaké př́iležitosti se užívají (/užívala)?

6. Uved’te místní př́ihody, písně, pověry apod. spojené s pěstováním vinné révy, výrobou a pitím vína.

\section{Dalš́í poznámky:}

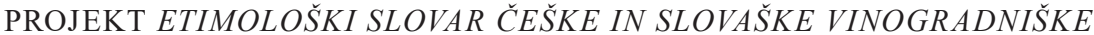 TER VINARSKE TERMINOLOGIJE}

$\mathrm{V}$ članku je predstavljen projekt Jezik tradicionalnega vinogradništva in vinarstva $v$ srednjeevropskem prostoru: etimologija in arealno jezikoslovje ter elektronski Etimološki slovar češke in slovaške vinogradniške ter vinarske terminologije, ki je rezultat tega projekta. Slovar je primarno namenjen jezikoslovcem, predvsem dialektologom, in zgodovinarjem, ki v njem lahko najdejo podatke, pomembne za svoje raziskovanje. Uporabljajo pa ga lahko tudi strokovnjaki drugih znanstvenih disciplin ter enologi in vinarji. 
Slovar vsebuje gradivo, pridobljeno s podrobnim izpisovanjem iz virov in literature ter z lastno raziskavo na terenu, zaradi katere je bilo v raziskavo vključenih tudi veliko takih čeških izrazov, ki jih drugje nismo zasledili. Vse analizirane besede so bile potrjene s preverjanjem v zgodovinskih virih, pri čemer smo želeli odkriti njihovo najstarejšo pojavitev. To je bilo mogoče predvsem s pomočjo elektronskih podatkovnih baz stare in srednje češčine, ki so pomemben pripomoček pri etimologizaciji čeških besed. Izbrani starejši češki izrazi so za ponazoritev in umestitev v kontekst opremljeni z zgledom, ki ima naveden vir. Osrednji del slovarja predstavlja etimologizacija zbranih čeških (in slovaških) izrazov s področja vinogradništva ter vinarstva, ki zajema določanje izhodiščne oblike oziroma vira prevzemanja in razlago morfološkega ter pomenskega razvoja. Ob izvoru besed je bil raziskan tudi njihov nadaljnji razvoj in stanje v sodobnem jeziku vinarjev. Češki (in slovaški) vinogradniški ter vinarski termini niso bili preučevani ločeno. Njihov razvoj je bil raziskan v širšem geografskem kontekstu, ki vključuje razvoj terminoloških sistemov določenega tematskega kroga v jezikih, ki so geografsko blizu češčini (in slovaščini), torej v nemščini, madžarščini, poljščini, slovenščini in hrvaščini. 


\title{
"What is the best language for Eastern Europe?" Lingua receptiva as a new approach in Slavic intercommunication research
}

\author{
Magdalena SteciąG \\ Inštitut za Poljsko Filologijo, Univerza Zielona Góra, Al. Wojska Polskiego 69, \\ PL-65-001Zielona Góra, M.Steciag@ifp.uz.zgora.pl
}

1.02 Pregledni znanstveni članek - 1.02 Review article

\begin{abstract}
Namen prispevka je obravnavati pojem lingua receptiva kot nov pristop v slovanskih študijah medsebojnega komuniciranja, ki omogoča analizo medjezikovnih stikov z drugačne perspektive in ki presega tradicionalne strukturalistične ali glotodidaktične pristope. Večina raziskav o lingua receptivi je bila doslej izvedena $\mathrm{v}$ povezavi s skandinavskimi in z romanskimi jeziki. Obstajajo pa tudi primeri prvih raziskav, vezanih na slovanske jezike - prispevek predstavlja pregled njihovih temeljnih rezultatov, ob tem pa tudi konceptov, ki so se v njih razvili.

The aim of the paper ${ }^{1}$ is to consider the notion of lingua receptiva as a new approach in Slavic intercommunication studies which allows to analyze interlingual contacts from a different perspective, going beyond the traditional structuralist or glottodidactic approaches. So far, most research on lingua receptiva has been conducted in relation to Scandinavian and Romance languages. There are, however, examples of initial research done on Slavic languages. This paper will present an overview of the main results of these studies, along with concepts developed in them.
\end{abstract}

Ključne besede: lingua receptiva, vključujoča večjezičnost, slovanski jeziki, vzhodna Evropa

Key words: lingua receptiva, inclusive multilingualism, Slavic languages, Eastern Europe

\section{Introduction}

The quantity and quality of interlingual contacts in East-Central Europe are the subject of a number of complex phenomena and processes that largely determine the shape of social reality in the region and influence the dynamically changing identity of nations that traditionally belong to the Slavic world. In short, since 1989,

${ }^{1}$ The article has been prepared within the framework of a research project "Lingua receptiva or lingua franca? The linguistic practices in the borderland area between Poland and the Czech Republic in the face of English language domination (ecolinguistic approach)" financed by the National Science Centre, Poland (agreement no. 2017/26/E/HS2/00039). 
or since the fall of Communism in some Slavic countries the sense of connection based on a shared Slavic identity has been gradually weakening. During the domination of the USSR, this connection was cherished. Afterwards, its place was taken by national identities based on such values as: ethnicity, territory, culture, history and religion as well as language. Raising the status of lesser Slavic languages to the rank of official languages (as in the case of Slovak, Serbian / Montenegrin, Croatian, Slovenian, Macedonian) is related to separatist tendencies and to the fact that new countries have appeared on the European map.

Given this situation, it would be difficult to imagine both the revival of the PanSlavism idea and the domination of one of the region's languages in transnational communication as Russian is no longer the lingua franca for Eastern European countries. It comes as no surprise then that travelling forums are full of tourists confused by the multitude of similar-sounding languages posing a question: "What language is the best for Eastern Europe?" referring to the political map of the continent divided by the Iron Curtain. It goes without saying that the answers they get are as different as their destinations.

Research on mutual intelligibility of related languages carried out by Charlotte Gooskens in an international research team may give us some insight into this matter. In their research, languages have been grouped on the basis of mutual intelligibility (Gooskens et al. 2017) using a large-scale web-based investigation with specially-designed test tools. The scope of the research has recently been widened to incorporate the Slavic languages family, although not all of them have been yet tested (see Table 1.). The results of the investigation are not surprising: the languages closest-related appear to be the most effective trigger for interlingual communication. In case of Western European Slavic languages one can even talk about 'the phenomenon of communicativeness' (Hofmański 2012). For tourists who posed the question on the internet forum, this research results mean that, for instance, if someone speaks Czech, he/she will be able to communicate with the Slovaks and (to a lesser extent) with Poles, whereas a Slovenian speaker will understand Croatian and Bulgarian to some extent. However, it seems that these connections are not symmetrical.

The situation of national languages in the region also overlaps with more general economic and political integration processes, such as globalization, migrations, as well as technological revolution. These conditions favor participation in a supranational communication community and change the cultural landscape of Eastern European countries in general and linguistic practices in particular. Important to note, Slavic languages "lean Westwards" and not towards each other. Among the reasons and indicators one can note the rapid growth of international words of English origin and an exponential growth of the number of Western languages students, in most cases English, which is prioritized in educational systems in the Slavic countries. 


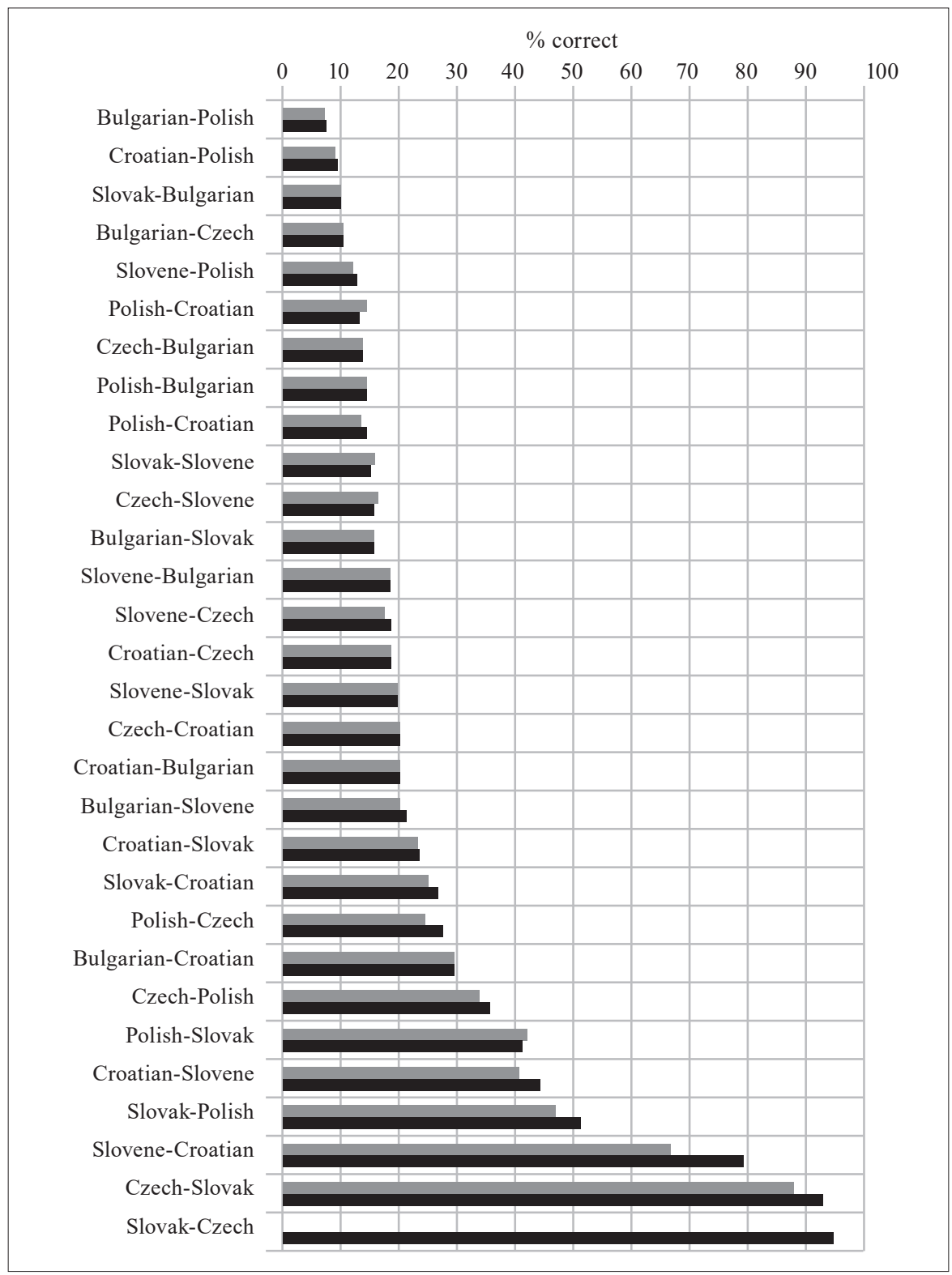

Table 1. Results of cloze tests in the Slavic language area (Source: Gooskens et al. 2017: 16).

In the context referred to in this article, an increase in the tourist traffic should be added to these conditions. There are millions of Western tourists visiting EastCentral European countries every year (see Table 2.). Croatia is the unquestionable tourism power in the region (8th place among all EU countries), which - according to the Eurostat research - is the most visited tourist destination for Germans $(21 \%$ of all tourists). The Czech Republic (11th place) and Poland (13th place) hold a quite 
strong position as well. However, it is the short-term big-city tourism that prevails in these countries. Prague and Krakow are especially popular among visitors from the West, which affects the linguistic situation in the cities - English has never been as widely spoken there as in the recent decades. Visitors perceive English as a lingua franca (ELF), a language that can be used everywhere. In fact, research confirms that ELF is the language of mass global tourism (Jaworski, Thurlow 2010). Increasing globalization of tourism, in turn, strengthens ELF's domination in transnational communication and leads to the modification of the hierarchy of languages not only in tourist centers, but also in the peripheries which aspire to participate in the global tourism market.

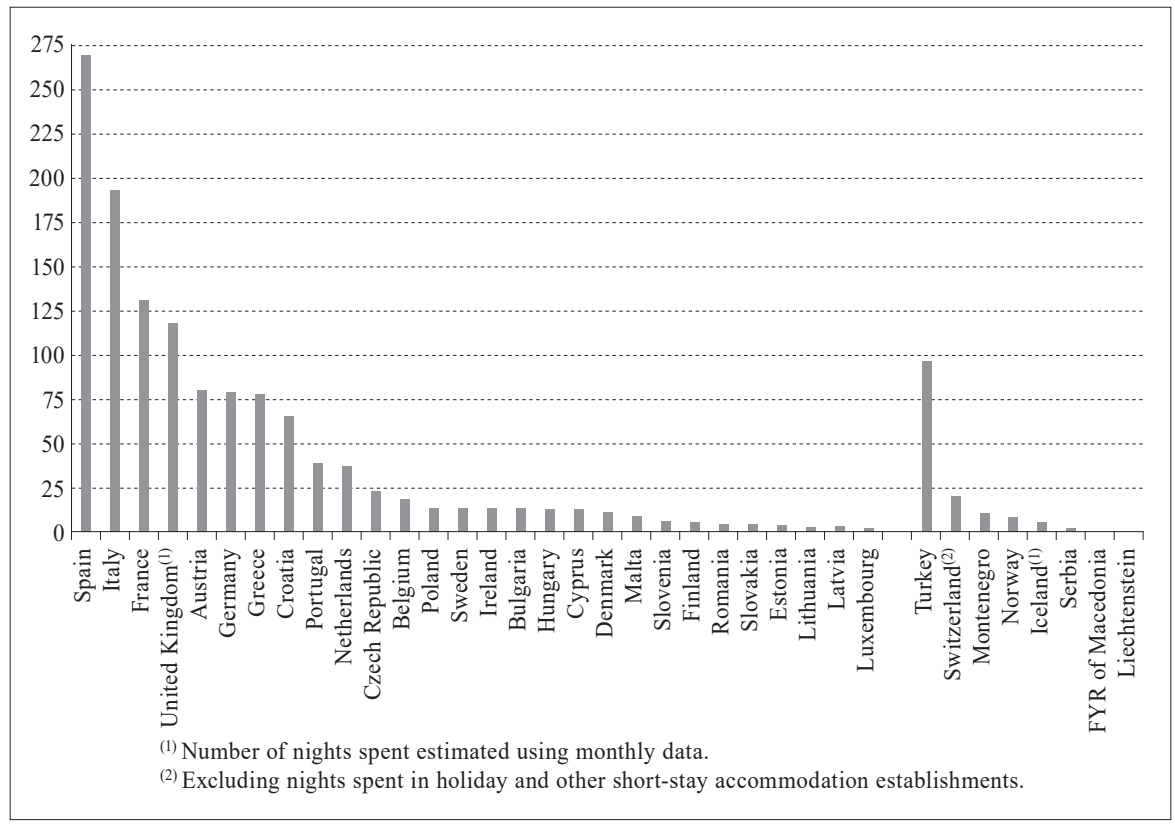

Table 2: Nights spent at tourist accommodation establishments (Source: http://ec.europa. eu/eurostat/statistics-explained/index.php/Tourism_statistics_-_nights_spent_at_tourist_ accommodation_establishments)

\section{New solutions: inclusive multilingualism and lingua receptiva}

Due to such conditions, Slavicists forecast that under the pressure of globalization in East-Central Europe, a two-level communication model will prevail: national languages at the local level, and a transnational language with a significant (and still growing) scope of functions (Walczak 2016), with a tendency to displace Slavic languages from a wide range of social communication, even from literature (Виденов 2013). 
With regard to the previously mentioned Slavic 'phenomenon of communicativeness', this model should be completed with an intermediate level, that is to say, an interlingual communication in the region where apart from global language the use of native languages will be taken into account. However, it is worth noting that such a situation does not reduce the assessment of the English language pressure on lower levels of communication in the region. As the model shows, the influence goes in one direction only (top-down) and is not mediated by another supranational language (see Table 3).

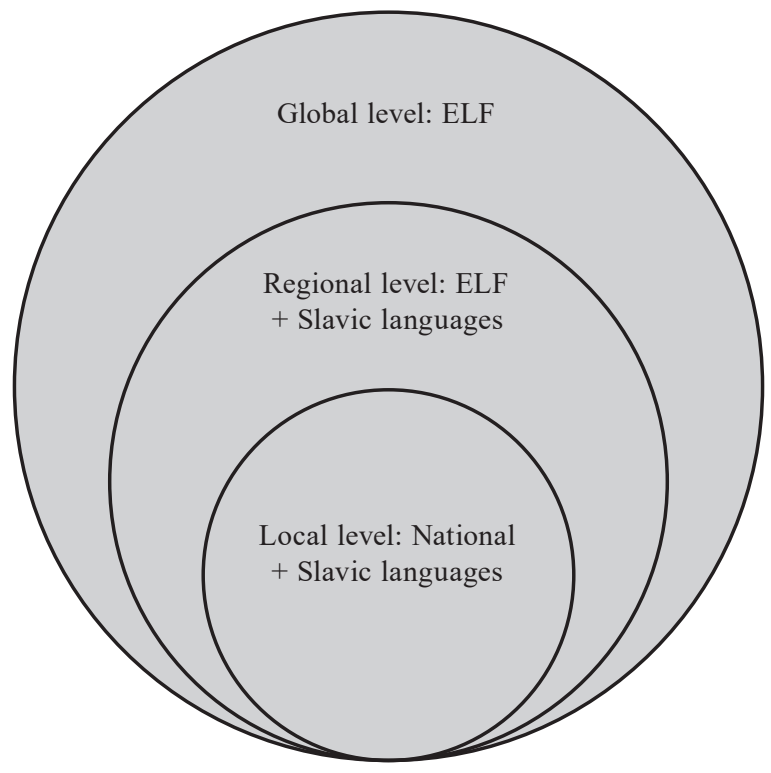

Table 3. Three-level communication model in Eastern Europe.

The model is obviously a simplification, as can be observed when referring back to the title question of this article. In fact, seeing the question from a different perspective may help us better understand the coexistence of different national languages and the global language in East-Central Europe. Thus, the traditional relationship between a country (nation) and a language needs redefinition in the direction of loosening their ties and recognition of possible multilingual arrangements. Such an approach could better reflect the dynamics of real changes in communication in the region.

In response to these challenges, more attention is paid to the observation of various models of multilingual communication (see: www.dylan-project.org). It shows that the communication practices of Europeans with varying ethnolinguistic backgrounds are based on strategies that can be compared in several dimensions (Bahtina-Jantsikene 2013: 23), namely:

1) mono versus multilingual strategies: from monolingual ('one language only', or OLON, and 'one language at a time', or OLAT) to multilingual ('all the languages at some time', or ALAST, and 'all language at all times', or ALAAT); 
2) exolingual versus endolingual communication strategies: from completely asymmetrical multilingual repertoires to the common language repertoire of communication participants.

These considerations lead to propositions of new practical solutions at an institutional level, also in the field of glottodidactics. First of all, the principle of 'mother tongue +2 foreign languages' promoted in the language policy of the European Union is widely criticized by scholars and experts. It is recognized that due to the traditional teaching of standard languages, this principle may be unrealistic. Even though implemented at a large financial cost and a great effort of the learners, such an approach separates them from their communicational needs and using the language in real-life situations. The focus on achieving competences and fluency in all language skills close to those of a native speaker seems to be an aim unnecessarily overstated. An 'English only' formula, a belief that English should be the ultimate communicative tool at the supranational level in the European Union, is also widely contested.

More realistic, feasible and more cost effective solutions are being proposed, both justified theoretically and occurred practically in the multilingual practices of Europeans. These solutions propose integrating different interaction strategies and communication modes. The use of English as a lingua franca (ELF), regional linguae francae (RLF), lingua receptiva (LaRa), code switching (CS) and translation with interpretation (TI) are then described as well-researched constituents of inclusive multilingualism (Backus et al. 2013). The idea of inclusive multilingualism (IM) developed by an international group of researchers assumes that in order to break the communication barrier resulting from limited knowledge of foreign languages these kinds of 'imperfect' but efficient modes of plurilingual communication should be promoted.

The most profitable element of all of those ways of multilingual communication is that they encourage participants to cooperate and provide mutual help. ELF brings along indulgence to derogation from standard norms of English, RLF in turn makes use of those language skills which are most useful and natural at a given time and in a given location, LaRa enables the participants to use their native languages to communicate, and CS matches the choice of an optimal language to meet the needs of speech. All of these options are of inclusive nature because they foster the extension of a common communication space. What is more, they improve multicultural understanding on fair terms: equality of interlocutors and respect towards their language diversity, as these are the core values of the European Union's foreign language policy.

The IM component, which should be given special attention in the context of the title question of this article, is the notion of lingua receptiva ( $\mathrm{LaRa})$, which allows to analyze the interlingual contacts from a new perspective, going beyond the traditional structuralist or glottodidactic approaches. The practical applicability of the concept has been proved in the context of language contacts in different borderland areas of Europe. As mentioned before, such research is more extensive in relation to Scandinavian and Romance languages. There are, however, examples of initial research on Slavic languages, especially in the context of communication between 
Czechs and Slovaks (Sloboda, Nábělková 2013) and also among Poles, Belarusians and Ukrainians (cf. the innovative PILaD concept in: Rehbein, Romaniuk 2014).

This notion arises from the idea of semicommunication introduced by Einar Haugen in the 1960s in the context of communication among Danes, Norwegians and Swedes in a situation where all interlocutors spoke just their mother tongue. The notion pointed to the shortages of such contacts which were metaphorically described as "the tricle of messages through a rather high level of "code noise" (Haugen 1962: 87). However, in the 1990s a change in the evaluation of this phenomenon could be observed: a shift from describing it as semicommunication to instead framing it as an efficient communication model. This shift, in turn, exposed some terminological problems. The term semicommunication was therefore replaced with a number of others, e. g.: receptive multilingualism, polyglot dialogue, intercomprehension, or lingua receptiva, abbreviated LaRa (Beerkens 2010).

Currently, LaRa is defined as "the ensemble of those linguistic, mental, interactional, as well as intercultural competences which are creatively activated when listeners are receiving linguistic actions in their 'passive' language or variety" (Rehbein, ten Thije, Verschik 2012: 249), and it is considered to be an effective means of communication between the members of diversified language communities in the context of using similar (yet different) languages in order to achieve mutual understanding. According to Kurt Braunmüller (2008) it is a mode used mainly in verbal communication, in a non-official setting, during face to face contacts, in which mutual understanding is important, and the emphasis is mainly on efficiency of the information exchange, content retrieval, without the intention to actually learn the other language. In the context of such communication 'at any price', the grammar rules and correctness play a secondary role, giving priority to pragmatics, situation and context conditions.

The research so far indicates that the very fact that closely related languages have so much in common and that their structures are similar, does not fully explain the success or failure of receptive communication between their users. What has been emphasized from the beginning is that the experience in multilingual practices and participants' awareness of communication are vital. In such a context, participants have to 'learn' the understanding of the interlocutor's language when communication is in progress. It is as important for an individual as for society which through long-time multilingual contacts has developed conventional discursive practices based on the common history of communicative events. Creating the common social reality in such a multilingual discourse opens the door for LaRa to be used in order to grasp understanding or comprehension, as Roos Beerkens (2010: 34) argues. In such a situation it is no longer only an imperfect 'tool' of communication. Rather, it should be seen as a building block of interculturality.

On the other hand, the possibility of utilizing this communication mode also depends on an explicit agreement between interlocutors or a foreign language policy in a given territory. Foregoing studies show that ideological factors play a significant role as they may strengthen, weaken or even block mutual understanding in language constellations burdened with a negative attitude (Bahtina-Jantsikene 2013: 21). 
Nowadays, LaRa in Europe is considered an "endangered language". Despite being in use in various borderland areas (where languages are similar and the national stereotypes and antagonisms reduced), it is being overshadowed by ELF which displaces a more difficult multilingual communication in interlingual contacts. However, in the light of IM these variants of transnational communication are not treated as competition since they both involve a similar communication goal: to achieve understanding in the multicultural setting. The assumptions, however, vary in both cases: whereas ELF assumes a general knowledge of common linguistic resource as a starting point leading to the differences in understanding and using different linguistic forms, LaRa assumes a diversified set of linguistic resources and a resulting effort is aimed at recognizing common forms and meanings in order to achieve understanding. As it is emphasized by Cornelia Hülmbauer (2014: 284):

Using the slogan of the European Union, one could distinguish between diversity in unity for ELF - i. e. a diversity component of negotiable forms within a framework of 'all speaking the same language', and unity in diversity for LaRa - i. e. a unity component of familiar forms within a framework of different languages.

The difference between the ELF and the glottodidactic EFL (English as foreign language) is also emphasized in this perspective. The first one is of inclusive nature as it is not based on the domination of 'native speakers' of English and does not seek reaching their level. However, in turn, it is a mode developed by participants of an interaction who commonly regard English as a foreign language.

The co-occurrence of LaRa and ELF in transnational communication in EastCentral Europe seems to be no longer a likely scenario but rather an existing language reality, although insufficiently examined. The first diagnostic studies show that even in the case of closely-related languages the interlingual communication is undergoing a significant transformation due to the influence of the omnipresent English. An example of such closely-related languages could be Polish and Czech, even in border areas where the semi-communicative practices are present and deeply socially rooted in a 'discourse of interculturality'. National languages, which until recently have been sufficient in everyday contacts, are now accompanied by a global language (Steciąg 2017). However, there is no doubt that the growing ELF role in transnational communication in Eastern Europe, both in different areas and situations of interaction, does not mean the exclusion of other Slavic languagesbased modes of communication, which are still worth developing. However, they do not need to be mutually-exclusive options. The IM perspective allows one to follow different interaction strategies taken in varying communication arrangements and language constellations.

\section{Conclusions}

Looking back at the title question of this paper, a negative answer can be given first: the 'English only' option is neither realistic nor beneficial. Current opinions of Slavicists who state that ELF is and will continue displacing national languages in different functions and communication areas on transnational level, are worth contrasting with completely different forecasts taken seriously in the English-speaking 
world. Nicholas Ostler (2010) believes that the status of ELF will diminish in the next decades due to the influence of three worldwide tendencies:

1) an equality tendency contributing to lowering the status of social elites which involves removing the language of their communication (ELF) to the natural native territories;

2) the increasing wealth and influence of world economies and demographic powers other than the USA (i. e. Russia, India, China) which will undermine the supremacy of the English-speaking nations and in turn will result in limiting the choice of ELF for international communication;

3) the advancements in translation technology, allowing immediate translation from language to language, strengthening the significance of national languages and reducing the need of any lingua franca in the future.

ELF will surely not disappear suddenly as Ostler emphasizes. However, the indications of its twilight are apparent in a symbolic, as well as practical sense. In turn, the inclusive perspective, proposed by the multilingualism researchers, brings the European intercommunication closer to the ideal outlined years ago by Umberto Eco (1995: 283) in the following way:

Polyglot Europe will not be a continent where individuals converse fluently in all the others language; in the best cases it would be a continent where differences of languages are no longer barriers to communication, where people can meet each other and speak together, each in his or her own tongue, understanding, as best as they can, the speech of others.

The 'zeitgeist' is also important for the shape of contemporary interlingual communication practices, or - to be more exact in relation to the challenges of the $21 \mathrm{st}$ Century linguistics - 'intellectual aura', understood as a more or less consistent and dynamic set of epistemological and ontological-axiological, as well as praxeological attitudes, which in reality affects the beliefs and behavior of people to a more or less conscious extent (Gajda 2013: 6). In the 'fluid reality' of postmodernism, characterized by multiple points of view and blurring of once sharp binary opposites (such as: nature - culture, objectivism - subjectivism, reductionism - holism, essentialism - relationism, universalism - contextualism, etc.), directing the attention of linguists to borderline, transient and non-standard forms of multilingualism seems to be necessary.

The general conclusion is that the language of understanding for East-Central Europe remains an imperfect mode requiring pragmatic effort and intercultural competence. Created through real-life contacts and communication situations, it resembles a kind of glocalised multilingua franca (Pennycook, Otsuji 2015: 177) integrating various interaction strategies in order to expand the common platform of understanding.

\section{REFERENCES}

Ad Backus, Durk Gorter, Karlfried Knapp, Rosita Schjerve-Rindler, Jos Swanenberg, Jan D. Ten Thije, Eva Vetter, 2013: Inclusive Multilingualism: Concept, Modes and Implications. European Journal of Applied Linguistics 1, 179-215. 
Daria Bahtina-Jantsikene, 2013: Mind Your Languages: Lingua Receptiva in EstonianRussian Communication. Utrecht: Utrecht University Repository.

Roos BeErkens, 2010: Receptive Multilingualism as a Language Mode in the Dutch-German Border Area. Münster: Waxmann Verlag GmbH.

Kürt BraunmüLLER, 2008: On the Relevance of Receptive Multilingualism in a Globalised World: Theory, History and Evidence from Today's Scandinavia. Hamburg: SBF.

Umberto Eco, 1995: The search for the perfect language. Oxford, Cambridge: Blackwell Publishers Ltd.

Stanisław GaJdA, 2013: Lingwistyka XXI wieku. Polonica 33, 5-13.

Charlotte Gooskens, Vincent J. van Heuven, Jelena Golubović, Anja Schüppert, Femke Swarte, Stefanie Voigt, 2017: Mutual intelligibility between closely related languages in Europe. International Journal of Multilingualism 15/2, 2-25.

Einar Haugen E, 1962: Semicommunication: The language gap in Scandinavian. Explorations in Sociolinguistics. Ed. Stanley Lieberson, Bloomington: Mouton. 85-94.

Wojciech Hofmański, 2012: Języki w kontakcie: Fenomen słowiańskiej komunikatywności. Slavia Occidentalis 69, 91-108.

Cornelia Hülmbauer, 2014: A matter of reception: ELF and LaRa compared. Applied Linguistics Review 1/5, 273-295.

Adam JAWORSKI, Crispin Thurlow, 2010: Language and Globalizing Habitus of Tourism: Towards a Sociolinguistics of Fleeting Relationships. Handbook of Language and Globalization. Ed. Norman Coupland. Oxford: Wiley, Blackwell. 255-286.

Nicolas OstLer, 2010: The Last Lingua Franca: English Until the Return of Babel. Bloomsbury: Walker Books.

Alaistar PenNYCOOK, Emi Otsuj, 2015: Metrolingualism. Language in the city. New York: Routledge.

Jochen Rehbein, Olena Romaniuk, 2014: How to check understanding across languages. An introduction into the Pragmatic Index of Language Distance (PILaD) usable to measure mutual understanding in receptive multilingualism, illustrated by conversations in Russian, Ukrainian and Polish. Applied Linguistics Review 1/5, 131-171.

Jochen Rehbein, Jan D. ten Thije, Anna Verschik, 2012: Lingua Receptiva (LaRa) - remarks on the quintessence of Receptive Multilingualism. International Journal of Bilingualism 3/16, 248-264.

Marian Sloboda, Mira NÁbĚLKové, 2013: Receptive multilingualism in 'monolingual' media: managing the presence of Slovak on Czech websites. International Journal of Multilingualism 2/10, 196-213.

Magdalena SteCiĄG, 2017: Lingua receptiva czy lingua franca? Pracownicy branży usługowoturystycznej o komunikacji czesko-polskiej na pograniczu (badanie ankietowe). Studia et Documenta Slavica 4, 59-75.

Bogdan WalczaK, 2016: Globalizacja językowa - przemiany i prognozy. Globalizacja a przemiany języków stowiańskich. Eds. Halina KureK, Małgorzata ŚwiĘCICKA, Monika Peplińska. Bydgoszcz: Wydawnictwo Pejzaż. 13-24.

МИХАИЛ ВИДЕНОВ, 2013: Езиковедски щрихи и етюди. София: Международно сочиолингви стическо дружество. 


\title{
LIST OF ABBREVIATIONS
}

\author{
ALAAT - 'all language at all times' \\ ALAST - 'all the languages at some time' \\ $\mathrm{CS}$ - code switching \\ EFL - English as foreign language \\ ELF - English as a lingua franca \\ IM - inclusive multilingualism \\ LaRa - lingua receptiva \\ OLAT - 'one language at a time' \\ OLON - 'one language only' \\ RLF - regional lingua franca \\ TI - translation with interpretation
}

\section{KATERI JEZIK JE NAJBOLJŠI ZA VZHODNO EVROPO? LINGUA RECEPTIVA KOT NOV PRISTOP V SLOVANSKIH RAZISKAVAH MEDSEBOJNIH KOMUNIKACIJ}

Količina in kakovost medjezikovnih stikov v vzhodni in srednji Evropi sta povezana s številnimi zapletenimi pojavi in procesi, ki v veliki meri določajo obliko družbene realnosti v regiji in vplivajo na dinamično spreminjanje jezikovnih pogojev narodov, ki tradicionalno pripadajo slovanskemu svetu. V takih razmerah si je težko predstavljati oživitev panslavistične ideje in prevlado enega od jezikov regije $v$ transnacionalni komunikaciji. Slovani napovedujejo, da bo pod pritiskom globalizacije $\mathrm{v}$ vzhodni in srednji Evropi naraščala težnja po izginjanju slovanskih jezikov iz širokega spektra družbene komunikacije. Po drugi strani pa raziskave, ki že potekajo, kažejo, da prepričanje, da bi morala biti angleščina končno komunikacijsko orodje na nadnacionalni ravni (t. i. formula English only), ni niti realistično niti koristno.

Kot odgovor na te izzive se vse več pozornosti posveča opazovanju različnih modelov večjezične komunikacije, ki se izvaja $\mathrm{v}$ regijah s prebivalci z različnimi etničnimi jeziki. Zamisel o vključujoči večjezičnosti (IM), ki jo je razvila mednarodna skupina raziskovalcev, je predstavljena kot nova rešitev za odpravo komunikacijskih ovir, ki izhajajo iz omejenega znanja tujih jezikov.

Komponenta IM, ki posebno pozornost posveča vprašanju o najprimernejšem jeziku za vzhodno Evropo, je izraz lingua receptiva (LaRa). Ta je opredeljen kot »sklop tistih jezikovnih, mentalnih, interaktivnih in medkulturnih kompetenc, ki se kreativno aktivirajo, ko poslušalci sprejemajo jezikovna dejanja v svojem 'pasivnem' jeziku ali različici« (Rehbein, Ten Thi, Verschik). LaRa kot komunikacijski fenomen temelji na načelu enakosti sogovornikov in ocenjuje njihovo etnično jezikovno ozadje, kar je tudi ključni vidik jezikovnih politik Evropske unije za spodbujanje ideje večkulturne Evrope s podpiranjem razvoja jezikovne identitete državljanov, zato ga štejemo za najpomembnejši element IM.

Sočasno pojavljanje LaRa in ELF (angleščina kot lingua franca) v transnacionalni komunikaciji v vzhodni in srednji Evropi se ne zdi več verjeten scenarij, ampak obstoječa - čeprav premalo raziskana - jezikovna realnost. Iz zaključkov, ki temeljijo na predhodnih ugotovitvah, je razvidno, da je komunikacijski model, ki se trenutno oblikuje na nadnacionalni ravni, podoben nekakšni glokalizirani multilingua franci (Pennycook, Otsuji), ki združuje različne strategije interakcije $\mathrm{z}$ namenom razširiti skupni temelj razumevanja. 


\title{
Неозапозичення в українському футбольному інтернет-дискурсі
}

\author{
ВітАлІй МАКСИмчУк \\ Національний університет «Острозька академія», вул. Семінарська, 2, \\ UA-35800,Ocmpoz,vitalii.maksymchuk@oa.edu.ua
}

\begin{abstract}
1.01 Izvirni znanstveni članek - 1.01 Original Scientific Article
Članek se osredinja na analizo novih prevzetih besed v sodobnem ukrajinskem nogometnem spletnem diskurzu. Avtor z različnih vidikov, kot so leksikografski, kronološki, funkcijski in semantični, predstavi španske, italijanske, angleške, nemške in druge nove prevzete besede. Opaža, da so španske in italijanske inovacije nacionalni identifikatorji, občasno pa razvijejo tudi posplošeno semantiko. Angleške inovacije poimenujejo vloge nogometašev na igrišču, vrste udarcev z žogo, časovna obdobja ipd. Nove prevzete besede so v ukrajinskem nogometnem spletnem diskurzu v konkurenčnem odnosu na slovnični, pravopisni in grafični ravni, prevladajo pa tiste novosti, ki niso v nasprotju z obstoječim jezikovnim standardom. Ne glede na to leksikalne dvojnice soobstajajo in širijo sinonimijo ukrajinskega jezika.

The paper focuses on the analysis of the new borrowed words in modern Ukrainian football Internet discourse. Using different criteria such as lexicographic, chronological, functional and semantic, the author describes Spanish, Italian, English, German and other new borrowed words. Spanish and Italian innovations are the national identifiers, but sometimes they gain generalized semantics. English new borrowed words name the functions of football players in the field, types of ball kicks, time periods, etc. In Ukrainian football Internet discourse new borrowed words compete on grammar, orthographic and graphic levels, but those innovations that do not contradict current linguistic standards prevail. However, lexical competitors peacefully coexist, expanding synonymous rows of the Ukrainian language.
\end{abstract}

Ključne besede: nogometni spletni diskurz, nova prevzeta beseda, inovacija, kontaminacija, konkurenčni odnos med besedami, semantika

Key words: football Internet discourse, new borrowed word, innovation, contamination, word competition, semantics

\section{0 Вступ}

Глобальне поширення інформації за допомогою сучасних комунікаційних технологій, зокрема інтернету, призвело до взаємодії лексичних систем різних мов. Це спричинює взаємопроникнення в рідномовну систему чужорідних елементів, які заповнюють наявні лакуни або розширюють синонімні ряди. На початку XXI ст. українські лінгвісти присвятили чимало праць аналізові слів іншомовного походження, використовуючи семантично тотожні 
терміни на позначення лексем, які нещодавно потрапили до мовного вжитку: неозапозичення (Клименко, Карпіловська, Кислюк 2008), нові запозичення (Городенська 2009), новозапозичення (Стишов 2017), новітні запозичення (Коробова 2017) тощо. Незважаючи на таку розгалуженість понять, неозапозичення зазвичай тлумачать як «нове слово іншомовного походження, адаптоване до системи української мови шляхом транскрибування (відображення звукової форми його прототипа в мові-джерелі) або транслітерування (відбиття графічної форми такого прототипа)» (Клименко, Карпіловська, Кислюк 2008: 19).

Однак поза увагою науковців залишилося дослідження нових слів іншомовного походження в мові спорту. Тут варто відзначити поодинокі праці О. Стишова, С. Карпіловської, 3. Валюх, де описано загальноспортивні неозапозичення (див., напр., Стишов 2017: 69-70). Заслуговує уваги дисертація I. Коробової, у якій авторка виокремлює такі лексико-семантичні групи неозапозичень: нові види спорту; назви спортивного знаряддя та приладів, що з'явилися завдяки новим видам спорту; місця для занять спортом; назви спортсменів; найменування новітніх спортивних понять і реалій (Коробова 2017: 74-78). Однак зазначені дослідження мають узагальнювальний характер і не описують грунтовно неозапозичень, які потрапили безпосередньо в мову певних видів спорту, зокрема футболу - гри з найбільшою вболівальницькою аудиторією. Про нові іншомовні слова у футбольному лексиконі згадував Ю. Струганець, зараховуючи до цього шару лексики номінації англійського походження вінгер і латераль (Струганець 2015: 119), а в одній із наших попередніх праць описано оновлення футбольної термінолексики за допомогою префіксоїдів суnер- і мега-, які подекуди приєднано до неозапозичень, напр., суперпартідасо, суперкатеначчо (див. Максимчук 2018).

Зважаючи на підвищену цікавість до футболу, з'яву додаткових засобів передачі інформації «наживо» (чати, блоги, форуми, текстові й відеотрансляції тощо), сучасний футбольний лексикон поповнюється значною кількістю іншомовних слів, які розширюють його виражальні можливості, експресивізують текст, надаючи йому чужомовних національних особливостей.

Мета статті - проаналізувати лексико-семантичні особливості неозапозичень і з'ясувати чинники їх з'яви в українському футбольному інтернет-дискурсі (ФІД).

\section{1 Критерії футбольних неозапозичень}

У сучасних наукових студіях чимало уваги звернено на критерії виокремлення запозичень, з-поміж яких вирізняють хронологічний, історично-культурний, порівняльний, текстово-філологічний і критерій імовірності (Совтис 2015: 227-228). Звісно, що для більшої достовірності висновків ці критерії застосовують комплексно. Зважаючи на те, що сучасний футбольний лексикон динамічний, багатоаспектний і пов'язаний із іншими дискурсами, до нього потрапляють запозичення $з$ інших галузей: політики, економіки, юриспруденції тощо. Тому в статті, щоб визначити належність іншомовного слова до футбольного неозапозичення, застосовано такі критерії: 
1) лексикографічний - інновації не зафіксовано в загальномовних словниках, зокрема тлумачних та іншомовних слів;

2) хронологічний - неозапозичення засвідчено у футбольному дискурсі останнього десятиріччя;

3) функційно-семантичний - лексема активно функціює у футбольному дискурсі й семантично пов'язана з футболом (рідше - навколофутбольними подіями, явищами, процесами).

Зазначимо, що до футбольного лексикону проникають інновації з інших дискурсів, однак відсутність у їхньому значенні експліцитної чи імпліцитної семи ‘футбол’ не дає підстави вважати їх футбольними неозапозиченнями.

\section{2 Неозапозичення: семантична характеристика}

За нашими підрахунками, упродовж останнього десятиріччя український футбольний лексикон поповнило понад 150 неозапозичень, зафіксованих на новинних ресурсах (football24.ua, ua-football.com, footboom.com, ua-gol.com, footballua.tv тощо) і сайтах уболівальницьких спільнот (1927.kiev.ua, fckarpaty. com.ua, ultras.org.ua та ін.). 3-поміж них переважають інновації з іспанської $(32,4 \%)$, італійської (26\%) й англійської (23,9\%) мов, меншу частину становлять запозичення з німецької (8,5\%) та інших європейських мов $(9,2 \%)$. Це пояснюємо зацікавленістю українців першостями Іспанії, Італії, Англії і Німеччини та значною репрезентацією їхніх матчів у медіапросторі, зокрема в інтернеті й телетрансляціях. Окрім того, відповідно до рейтингу Міжнародної федерації футбольної історії та статистики (IFFHS) 2017 р. 3-поміж європейських чемпіонатів найсильнішими визнано іспанський, англійський, італійський, французький і німецький ${ }^{1}$, що зумовлює проникнення лексем із відповідних мов до інших футбольних лексиконів. Значну кількість іспанізмів спричинює й те, що українська вболівальницька спільнота цікавиться південноамериканським футболом (чемпіонатами Бразилії, Аргентини, Колумбії, Кубком Лібертадорес тощо), у дискурсному описі якого переважає іспанська мова.

\section{1 Семантичні особливості іспанських неозапозичень}

Із-поміж іспанізмів у сучасному футбольному дискурсі поширені неозапозичення, що походять від кольорів клубної форми, напр., франхівердес (ісп. franjiverdes «зелено-смугасті») - ФК «Ельче», блаугранас (катал. blaugranas «синьо-гранатові») - «Барселона», вердібланкос (ісп. verdiblancos «зелено-білі») - «Бетис», франхірохос - (ісп. franjirojos «смугасто-червоні») - «Райо Вальєкано», рохібланкос (ісп. rojiblancos «червоно-білі») - «Севілья», альбіселесте (iсп. albiceleste «біло-блакитні») - збірна Аргентини. Ці лексеми

${ }^{1}$ The Strongest National League of the World: Spain's La Liga Again Number 1! Retrieved 25.12.2018 on https://iffhs.de/the-strongest-national-league-of-the-world-spains-primeradivision-again. 
розширюють первинне значення колоратива в мові-джерелі, однак в українському ФІД їх сприймають лише як метафоричні найменування футбольних команд, пор.: «Рохібланкос» хочуть зберегти у складі Саміра Насрі (ua-football.com, 21.12.2016); Підопічні Дієго Сімеоне, продемонструвавши яскраву гру, розбили на своєму полі «франхірохос» (football24.ua, 25.08.2013); «Франхівердес» покинули зону вильоту, а "рохібланкос» туди опустилися football24.ua, 07.03.2015); У Лізі Свропи «вердібланкос» закінчили свій илях на стадіï 1/16 фіналу... (footballua.tv, 21.06.2019); Дерліс Гонсалес не забив пенальті і врятував альбіселесте від фіаско (ua-football.com, 20.06.2019).

Рідше іспанські неозапозичення використовують для перифрастичного найменування команди: а) за народом, що мешкав на території, яку представляє команда, пор.: чарруа (iсп. charrúas) - збірна Уругваю; чарруа - «індіанський народ, що мешкав на території сучасного Уругваю, північно-східної Аргентини та південної Бразилії: Однак рахунок 2:0 не надломив чарруа (ua-football.com, 26.03.2016); б) за назвою жителів адміністративного округу міста, за яке грає команда, напр., нервьоненсес (ісп. nervionenses) - «Севілья»; Нервіон - «адміністративний округ м. Севілья»: Таким чином «нервьоненсес» хочуть знайти заміну Тімоте Колодзейчаку... (ua-football.com, 30.12.2016). Варто зауважити, що поряд із цією інновацією використовують іменник нервіонці, утворений від топоніма Нервіон за допомогою українського словотворчого форманта, пор.: Напередодні нервіонці програли Леванте (1:2) на виїзд (football24.ua, 28.04.2018). Уживання цих лексем залежить винятково від мовних смаків і уподобань авторів футбольних текстів.

Значну групу іспанізмів становлять номінації, сконструйовані від назви футбольного клубу або міста, яке він представляє, як-от: мадридиста (ісп. madridista) - «Реал» (Мадрид), барселоніста (ісп. barcelonista) - «Барселона», севільїста (ісп. sevillista) - «Севілья» тощо. Такі неозапозичення іменують як гравців певної команди, так і її вболівальників, що свідчить про розширення семантики лексем, витворення в них багатозначності, пор.: Мадридиста Гуті із шанувальником Королівського клубу - Расселом Кроу (football24. uа, 25.03.2016) - Я сам каталонець, «мадридиста». А він ось за Атлетик (football.ua, 27.05.2013); Барселоніста Педро може зіграти свій сотий матч в Ла Лізі (fanclubfootball.at.ua, 21.04.2012) - ...nросто в своєму фанатичному угарі відбулась втрата, з одної сторони, досить иікавого в висловленнях, але фанатично збоченого барселоніста (ua-football.com, 11.12.2016); Чи під силу андалузиям обіграти лідера «Барселону», якій «севільїстас» програли лише одного разу в останніх 3 матчах (footballua.tv, 27.09.2012) - Вболівальники туру. Севільїстас на виїзді у Малазі (bfootball.com.ua, 25.08.2015).

Сучасний футбольний лексикон активно поповнюють іспанізми, які називають часові проміжки, приміром, темпорада (ісп. teтporada) - «футбольний сезон», претемпорада (ісп. pretemporada) - «час перед початком або продовженням футбольного сезону; міжсезоння, передсезоння», хорнада (iсп. hornada) - «окремий тур футбольного сезону», nартідо / napmidaco (icп. partido / partidazo) - «футбольний матч» тощо. Такі номінації найчастіше використовують, описуючи поєдинки іспанського чемпіонату, рідше - міжнародні матчі за участю команд з іспанськомовних країн: До сорока 
голів Кріштіану у цій темпораді доплюсував ще й дев'ять гольових передач (football24.ua, 01.07.2011); Між іншим, це вперше при Зізу Реал балансує на межі 3-х пропущених за період претемпоради (1927.kiev.ua, 08.08.2019); Чергова хорнада Ла Ліги виявилась багатою на подіï (football24.ua, 14.05.2013); У поки щзо одному із найкрасивіших партідасо изьогорічної Прімери «Вільяреал» обіграв «Еспаньйол» (football24.ua, 31.01.2011).

Значного поширення у футбольному дискурсі набув іспанізм голеадор (iсп. goleador) - «футболіст, здебільшого нападник, що забиває голи; бомбардир», якого, проте, не фіксують загальномовні словники: Український голеадор зацікавив «Динамо» (football-ukraine.com, 11.12.2018). Окрім того, до лексикону ввійшли неозапозичення, що номінують гравців за амплуа, як-от, енганче (ісп. enganche) - «плеймейкер, десятка», портеро (iсп. portero) - «воротар». Такими одиницями зазвичай іменували футболістів із іспанськомовних країн і вони слугували своєрідними маркерами національної ідентичності, напр.: Обидві команди виглядали гідно, проте все у матчі вирішила неймовірна гра аргентинського енганче «Палермо» Хав'єра Пасторе (football24.ua, 14.11.2010). Хоча зараз спостерігаємо часткове розхитування цієї тенденції, коли аналізовані неозапозичення позначають футболістів інших національностей, напр., Олександр Іванович [Різниченко] виконував роль «енганче», опиняючись, то на лівому фланзі атаки, то на правому, а то й діючи з глибини! (fcbrovar.obolon.ua, 28.05.2015), ...однак Бебе, Алегрia, Медран і Морено відчули, наскільки складно забити молодому портеро [Андрієві Луніну] (football24.ua, 05.12.2018).

Меншою кількістю одиниць представлені іспанізми, які називають: а) уболівальників - інчада (ісп. hinchada), інчас (ісп. hinchas), cocio (ісп. socio) - «офіційно зареєстрований уболівальник; член клубу»: Інчада «Барселони» не хоче зустрічі з «Реалом» у півфіналі ЛЧ (football24.ua, 12.04.2013); Потужний перфоманс інчас «Реала» (bfootball.com.ua, 13.05.2015); Дуже ризиковане рішення очільника клубу призвело до обурення значної кількості сосіос... (football24.ua, 22.06.2019); б) уболівальницький рух на підтримку футбольного клубу - мадридизмо (ісп. madridismo), севільёнізм (ісп. sevillismo): Бракує слів, аби висловити вдячність за все, щзо ти зробив для ичієїроздягальні, Реала та мадридізмо (football24.ua, 31.05.2018); Приклад севільїнізму червоно-біла родина на «Рамон Санчес Пісхуан» (football24.ua, 02.06.2017); в) чемпіонати Іспанії та іспанськомовних країн Центральної Америки, як-от: апертура (ісп. apertura), клаусура (ісп. clausura), примера (ісп. primera), сегунда (ісп. segunda), mерсера (ісп. tercera). Номінації на позначення вищих ліг активно ввійшли до сучасного футбольного лексикону, напр.: Альбасете з Романом Зозулею було близьке до виходу в Примеру... (footballhub.com.ua, 26.06.2019); Його команда у матчі восьмого туру Апертури переграла Кафеталерос із рахунком 4:1 (champion.com.ua, 18.09.2018). Натомість неозапозичення, що називають нижчі ліги, уживають здебільшого на сайтах букмекерських контор і футбольних ресурсах у функції називних речень (пор.: ІСПАНІЯ: Терсера - Група 1 (myscore.ua); Іспанія| Терсера Дивізіон (favorit.com.ua)), зрідка їх використовують у текстових повідомленнях, як-от: «Атлетіко Мадрид В» виступає в національній лізі «Терсера», яка є четвертим дивізіоном в Іспанії 
(sportbuk.com, 04.03.2016). Це засвідчує низький рівень уболівальницької зацікавленості нижчими лігами іспанської першості й унеможливлює швидку узуалізацію таких неозапозичень.

Сучасний український ФІД також засвоїв поодинокі іспанізми, які стосуються власне гри, зокрема забитих м'ячів, напр.: голасо (ісп. golazo) - «гарний гол»; голеада (iсп. goleada) - «велика кількість голів, забитих в одному матчі»; ремонтада (iсп. remontada) - «ситуація, за якої одна з команд відігрує великий рахунок у матчі чи двоматчевій зустрічі»: Божевільний голасо Златана Ібрагімовича (footballhub.com.ua, 03.06.2019); Почав голеаду Фірміно, який опинився першим на добиванні (football24.ua, 13.01.2016); Перед сьогоднішнім поєдинком «Севілья» мала значні кадрові втрати, щзо зменшувало їх шанси на ремонтаду ще більше (football24.ua, 18.08.2016).

Зрідка іспанізми виявляють словотвірний потенціал на українському грунті, стаючи базою для конструювання дієслівних інновацій, напр.: $\mathrm{Bu}$ «тікітачите» у середині поля, ми ловимо вас на контрах (football24.ua, 21.11.2017); від тікі-така (icп. tiqui-taca) - «тактика, що передбачає володіння м'ячем упродовж тривалого часу».

Загалом іспанські запозичення в українському ФІД розширюють виражальні можливості футбольного лексикону та здебільшого слугують своєрідними національними ідентифікаторами текстів.

\section{2 Семантика неозапозичень італійського походження}

Активне проникнення італізмів до українського футбольного лексикону зумовлене підвищеною цікавістю українців до Серії А. Цьому, зокрема, сприяв перехід Андрія Шевченка з київського «Динамо» до «Мілана» 1999 р. і, як наслідок, трансляції італійської першості на вітчизняному телебаченні. На сучасному етапі італізми побутують в українському футбольному лексиконі, окремі з них, напр., скудетто, потрапили до словників неологічної лексики (див. НС3 2008: 232).

Здебільшого лексеми італійського походження називають футболістів за амплуа або функцією на полі: капоканоньєре (іт. capocannoniere «найкращий бомбардир»), медзала (іт. mezzala «універсальний півзахисник, який бере участь і в обороні, і в атаці»), естерно (іт. esterno «крайній півзахисник»), реджиста (іт. regista «гравець, що конструює атаки з глибини»), треквартиста (іт. trequartista «атакувальний півзахисник»), портьєрі (іт. portieri «воротар»), барічентро (іт. baricentro «центральний півзахисник»), чентрокампіста (іт. centrocampista «півзахисник»), атаканте (іт. attaccante «нападник»), терцино (іт. terzino «крайній захисник») тощо. Пор. у контекстах: ...однак після приходу Гасперіні чентрокампіста втратив місце в основі (football24.ua, 03.01.2014); В останні роки найпопулярнішими схемами в Італіі були 3-5-2 та 4-3-3. I жодна з них не передбачає треквартисту (football24. uа, 03.03.2015); Вперше «капоканоньєре» Серії А Тоні став у сезоні 2005/06... (footballua.tv, 26.05.2017). Зазвичай такими неозапозиченнями номінують італійських гравців, підкреслюючи їхню національну ідентичність, або нападників італійських клубів: I якщо іспанещьь по своїй суті саме форвард, то 
Кандрева - ие і териино, і мецала, і естерно, і все щзо завгодно (football24.ua, 27.07.2016); Аргентинець з 20 м'ячами в активі - кращий атаканте в Італіі (bfootball.com.ua, 01.05.2015).

В українському ФІД зафіксовано італізми, що вказують на належність гравців до команди, названої твірною основою: ювентіно (іт. juventino) - «Ювентус», інтеріста (іт. interista) - «Інтер», міланіста (іт. milanista) «Мілан», лаціале (іт. laziale) - «Лаціо» тощо. Пор.: Цікаво, щзо його кумиром дитинства був Алессандро Дель П'єро, а його життя змінив інший ювентіно (ua-football.com, 30.01.2019); Цим колишній інтеріста [Златан Ібрагімович] зробив все, щуоб ускладнити своє потрапляння до изього пантеону (1927.kiev. ua, 14.05.2016); Перші слова «міланіста» Балотеллі (footballtransfer.com.ua, 30.01.2013); У першому колі «Дженоа» мінімально переміг «лаціале» з рахунком 1:0 (footballua.tv, 06.02.2015). Здебільшого такі номінації мають подвійну семантику, адже також іменують уболівальників тієї чи тієї команди, пор.: ... однак вболівають «ювентіні» доволі стримано, більшою мірою реагуючи на позитивні або негативні моменти у грі своєї команди (lb.ua/sport, 20.02.2009). Окрім того, український ФІД поповнив іменник тифозерія (іт. tifoseria), який позначає італійських уболівальників загалом: Тифозерія «россо-нері» швидко полюбила потужного і забивного ліберійия (ua.tribuna.com, 02.04.2013).

Чимало італізмів називають команди за кольором їхньої форми, напр., скуадраадзура (іт. squadraazzurra «синя команда») - збірна Італії: Так, щзо СкуадраАдзура ще не раз носа втре (fckarpaty.com.ua, 02.06.2011); нерадзурі (іт. пегаzzигro «синьо-чорні») - «Інтер»: Нерадзурі задивляються на вериину. Відеоогляд матчу Інтер - Сампдорія (ua-football.com, 25.10.2017); росонері (іт. rossoneri «червоно-чорні») - «Мілан»: Наставник «росонері» поділився очікуваннями від матчу проти «Ювентуса» (football24.ua, 24.11.2012); б'янкочелесті (іт. biancocelesti «біло-блакитні») - «Лаціо»: Б’янкочелесті теж сповідує атакувальний футбол (bfootball.com.ua, 08.04.2015); блучерк'яті (іт. blucerchiati «синє обкантування») - «Сампдорія»: Очевидно, «блучерк'яті» не вірять, що їм вдасться втримати гравия, котрий рветься до Луческу (footballgazeta.com, 31.05.2016); джалоросі (іт. giallorossi «жовто-червоні») «Рома»: "Джалоросі» готові заплатити за цей трансфер понад 5 млн. євро (champion.com.ua, 23.12.2010). Безперечно, частотність уживання цих неозапозичень неоднакова. Перевагу мають ті одиниці, що номінують клуби, які, окрім внутрішньої першості, грають у єврокубках, зокрема Лізі чемпіонів. Адже постійна участь команди в різних турнірах збільшує кількість згадок про неї та водночас частотність лексем на її позначення: ... «джалоросі» не покладають надій на те, щоб підписати Едіна Дюеко (football24.ua, 20.07.2015); Едо Рейя - король «б’янкочелесті»! (football24.ua, 19.01.2014).

В українському ФІД також уживають італізми тессера (іт. tessera) - «картка (абонемент) на стадіон», меркато (іт. mercato) - «період, у який футбольний клуб може продавати й купувати гравців», джорната (іт. giornata) - «тур, ігровий день» тощо. Ці інновації використовують для опису італійського футболу, що надає їм національної ідентичності, пор.: Знаю випадки, щзо навіть італійці, які подавали заявку на тессеру, чомусь ї̈ не отримали, щзо вже говорити про іноземиів (football24.ua, 20.11.2012); Серія А: підсумки 
зимового меркато (1927.kiev.ua, 02.02.2017); ...а вже у вівторок на Апенніни чекає наступна джсоната (futbol.co.ua, 16.09.2016).

Прикметно, що футбольний лексикон поповнили італійські неозапозичення, утворені від антропонімів. Приміром, іменник кассаната (іт. cassanate) походить від прізвища нападника А. Кассано, який із 2002 року почав конфліктувати 3 тренерами й керівництвом «Роми», раптово залишаючи тренування та висуваючи неоднозначні претензії: Крім того, відомо, щзо «Сампдорія» в односторонньому порядку може припинити співпрацю з Антоніо, якщо той в черговий раз влаштує свою знамениту «кассанату» - відмову від тренувань та інші істерики (ukr.segodnya.ua, 09.08.2015). Уважають, що це слово вигадав Фабіо Капелло, тодішній тренер римлян, а італійські журналісти словом кассаната регулярно називають «будь-яку поведінку, що шкодить командному духу» ${ }^{2}$, утворюючи відантропонімні деривати за його моделлю, пор.: Prima c'erano le cassanate, poi sono arrivate le balotellate per arrivare alle niangate (ilmilanista.it, 09.06.2016). Інновації balotellate й niangate вказують на типову поведінку нападників М. Балотеллі й М. Ньянга.

Іменник nioлізм (іт. piolismo), утворений від прізвища С. Піолі за допомогою суфікса -ismo, позначає тактичну схему, яку використовує цей тренер: Перш за все, успіх відбувся завдяки тому, що тепер у італійській пресі називають «піолізмом», тобто гармонічним поєднанням антагоністичних стилів: обережності Трапаттоні з агресивними $і$ динамічними атаками та контратаками Земана (football24.ua, 02.06.2015). В італійських медіях за цією моделлю конструюють назви тактик інших тренерів, пор.: Dal Bielsismo al Piolismo: analisi e analogie dell'ascesa e declino di due modelli tattici (laziochannel.it, 21.09.2015), які поступово потрапляють у російськомовний сегмент українського інтернет-дискурсу: На одном испанском сайте статью о Мартино даже уже успели озаглавить "Бьелсизм в “Барселоне”" (ua-football.com, 23.07.2013). Ідеться про тактику аргентинського тренера М. Б'єлси.

Поодинокі італійські неозапозичення зумовлені прецедентними ситуаціями, тому їхня інтерпретація вимагає від реципієнта фонових знань. Скажімо, корупційні скандали в італійському футболі спричинили з'яву лексем тотонеро (іт. totonero) - «незаконні ставки на футбольні матчі» й кальчополі (iт. calciopoli) - «корупційна змова за участю провідних команд італійського футболу 2006 р.». У сучасному ФІД лексема кальчополі частково втратила свою первинну семантику і її вживають, щоб найменувати розслідування, пов'язане з договірними матчами в Україні: Украӥнське Кальчополі. Хронологія спецоперації проти договірних матчів (ua-football.com, 22.05.2018). Таке використання призводить до деонімізації неозапозичення й надає йому семантики узагальненості.

Після перемоги Португалії на Чемпіонаті Європи-2016 римська газета «Corriere dello Sport» опублікувала статтю під заголовком «Portogallissimo!»,

2 Марк РАЙАН, 2013: Фабио Капелло. Босс. Пер. с англ. И. Древаль. М.: Издательство АСТ. Доступно 25.12.2018 на https://www.rulit.me/books/fabio-kapello-boss-read-313722-1. html. 
який утворено від назви країни за допомогою суфікса -issimo, щоб висловити абсолютне захоплення, схвалення (пор. bravissimo). Саме з такою семантикою цей італізм транслітерували українські інтернет-видання, оглядаючи реакцію світових медій на тріумф португальської збірної, пор.: «Португаліссімо!»: Реакиія 3МІ на перемогу Португалії на Євро-2016 (football24.ua, 11.07.2016); «Португаліссімо»! Що пише європейська преса про фінал Свро-2016 (tsn.ua/ prosport, 11.07.2016).

Загалом італізми в українському ФІД стають національними ідентифікаторами місцевого чемпіонату та пов'язані з прецедентними ситуаціями, що відбулися в італійському футболі.

\section{3 Семантика англійських неозапозичень як продовження традицій}

Сучасні дослідники стверджують, що в українському спортивному лексиконі та публіцистиці загалом переважають номінації, запозичені з англійської мови, зокрема їі американського варіанта, які становлять понад 80\% від усіх одиниць (див. Коробова 2017, Стишов 2017). Однак, за нашими підрахунками, у ФІД зафіксовано лише 23,9\% неозапозичень-англізмів. Це зумовлено тим, що впродовж XX ст. терміносистема українського футболу формувалася на базі англійської мови, і саме тоді англізми активно проникали до футбольного лексикону, де вже стали узуальними одиницями. Сучасні англійські запозичення фактично заповнюють пропущені лакуни та, як порівняти з іспанізмами й італізмами, швидше втрачають семантику національної ідентичності. Це частково пов'язуємо з тим, що трансляції міжнародних футбольних матчів (Ліги чемпіонів, Ліги Європи, національних збірних тощо) субтитрують англійською мовою, а також зі значною розгалуженістю англійськомовного футбольного дискурсу.

Новітні англізми зазвичай номінують футболістів за позицією на полі, уточнюючи їхні функції та зони відповідальності, як-от: свіnер (англ. swiper «вільний захисник»), вінгер (англ. winger «крайній атакувальний півзахисник»), вінгбек (англ. wingback «крайній захисник»), бокс-ту-бокс (англ. box-to-box «центральний півзахисник, який може створювати й руйнувати атаки»). Пор.: Сарті став чи не першим в Італії кіпер-свіпером, тобто воротарем-ліберо (ua-football.com, 26.02.2019); Вінгер «Волині» повернувся в УПЛ (football-ukraine.com, 27.06.2019); Вінгбек «Челсі» вирімив піти з команди (footballtransfer.com.ua, 24.10.2018); Півзахист грав дуже позиційно, Поль не сильно втручався в гру, проте потім - ие вривання в штрафрну це дія справжнього 8-го номера. Справжній бокс-ту-бокс (ua-football.com, 16.06.2018). Як бачимо, з-поміж них немає лексем, що позначають основні амплуа гравців, оскільки такі одиниці вже стали узуальними, напр., голкіпер, бек, хавбек, форвард.

Значну групу англізмів становлять назви вболівальників. Проте, якщо 3-поміж італійських та іспанських запозичень переважають найменування фанів конкретної команди (приклади див. вище), то англізми мають узагальнену семантику та сленгове походження: глоріхантер / глор (англ. glory hunter / glor) - «уболівальник, який підтримує фаворита», траблмейкер (англ. 
troublemaker) - «уболівальник, що бере участь у хуліганських акціях», cannортер (англ. supporter) - «уболівальник, вірний одній команді» тощо. Це й віддзеркалено в контекстах: Так, середній украӥнський любитель футболу - глоріхантер (forum.metalist-kh-stat.net.ua, 29.04.2016); Тому німу фанатів на матчі заповнює лише з десяток харківських юнаків-траблмейкерів (иаfootball.com, 23.11.2017); Збірна України отримала ще одного саппортера у Франиіï (football24.ua, 13.05.2016). Як бачимо з прикладів, ці неозапозичення не мають семантики національної ідентичності, що призводить до їх частотності в сучасному футбольному інтернет-дискурсі i, як наслідок, швидшої узуалізації.

Окремі англізми уточнюють і розширюють футбольну термінологію, називаючи:

a) удари по м'ячу, типи передач: капбол (англ. cupball) - «вирішальний удар у кубковому матчі», тандерболт (англ. thunderbolt) - «дуже сильний удар», лонгбол (англ. longball) - «довга навісна передача», кікс (англ. kicks) - «невдалий удар по м'ячу», сейв (англ. save) - «вдалий стрибок воротаря, що рятує команду від гола»: Одним із очевидних иляхів для атак суперника, які грають проти римлян, є лонгболи за спини захисній лініі... (football24. ua, 24.04.2018); ...я чомусь згадую отой «кікс» Михайлова (dynamo.kiev.ua, 10.10.2018); Лунін здійснив класний сейв на тренуванні Реала (football24. ua, 02.08.2018). У деяких випадках спостерігаємо розширення значення інновації, коли вона означає не сам удар, а гол, забитий таким ударом, пор.: Бомбезний тандерболт зі штрафного забили в Чехії (football24.ua, 18.11.2015);

б) футбольні часові проміжки: матчдей (англ. matchday) - «день, коли відбувається матч», вінстрік (англ. winstreak) - «переможна серія ігор»: Господарі «Ювентус Стедіум» у компенсований час уникнули програшу в дербі, але про продовження вінстріку довелося забути (football24.ua, 08.05.2017); Продовжити свій суботній матчдей карпатівиям довелось у спарингу проти бронзового призера чемпіонату Білорусі (footboom. $\mathrm{kz}, 11.02 .2017)$. Інновація фергі-тайм (англ. fergie time «доданий час до доданого часу») походить від прізвища тренера «Манчестер Юнайтед» Алекса Фергюсона, адже під його керівництвом команда часто забивала на доданих хвилинах матчу: Примітно, щзо всі вони [перемоги] здобуті наприкіниі матчів - у так званий «Фергі-тайм» (football24.ua, 23.10.2017);

в) команди, їхні склади: локал-тім (англ. local team) - «місцева команда», андердог (англ. underdog) - «команда, що має малі шанси перемогти», лайнап (англ. line-ир) - «склад команди»: «Карпати» натомість не могли запропонувати майже нічого, окрім самої традиції локал-тіму (football24. uа, 01.07.2015); Німеччина - Мексика: андердог б'є фаворита. Перша сенсація Чемпіонату Світу-2018 (ua.tribuna.com, 18.06.2018); Питань до лайнапу Манчестер Сіті практично немає (football24.ua, 12.08.2018);

г) результат матчу: клін-шит (англ. clean sheet) - «гра без пропущеного гола»: 5 воротарів оформили по 3 клін-иити... (football24.ua, 16.07.2018) тощо. 
Окрім того, англійські основи виявляють потужний словотвірний потенціал, адже стають базою для конструювання дієслівних інновацій на українському мовному грунті: сейв - сейвити; кікс - кіксанути; суппорт - суппортити; глор - глорити тощо: Бразилець був сам-саменький у штрафному, але Пінту сейвить ефектно і ефективно... (football24.ua, 08.02.2012); Ще до перерви був момент, коли малинський гренадер пробивав з меж карного майданчика, але кіксанув у руки воротареві... (fcmalynsk.club, 18.06.2019); В другій половині зустрічі всі активні фанати перемістились на край сектора, де стюарди не могли заважати суппортити... (ultras.org.ua, 04.04.2009).

\section{4 Семантика новітніх запозичень із німецької мови}

Неозапозичення з німецької мови, рідковживані в українському футбольному дискурсі, зазвичай називають збірну Німеччини, як-от: бундесманшафт (нім. Bundesmannschaft), маншафт (нім. Mannschaft), національманншафт (нім. Nationalmannschaft), бундесмашін (нім. Bundesmaschine), що в перекладі означає «федеральна (національна) команда»: Сдиної поразки бундесманшафт зазнала в матчі з Алжиром (1:2) на ЧС-82 (footballua.tv, 21.06.2014); ...можна пригадати гарячі обговорення в німецькій пресі щодо вибору першого номера для Національманншафт (football24.ua, 21.10.2018); ...а за 2 дні після иьього національна дружина Португалії протистоятиме німецькій Бундесмашін (football24.ua, 24.12.2013).

В поодиноких випадках натрапляємо на інновації, що іменують німецькі клуби: а) за кольором форми, приміром, ротен (нім. Rothen «червоні») - «Баварія»: Тепер «ротен» повинні домовитися з «папугами» щодо суми трансферу (football24.ua, 17.07.2019); шваригельбен (нім. Schwarzgelben «жовто-чорні») - «Боруссія» (Дортмунд): Дебютним голом за «шваригельбен» відзначився Пако Алькасер (football24.ua, 15.09.2018) тощо; б) за загальною назвою, покладеною в основу номінації - прізвиська команди, напр., кнаппен (нім. Knарреп «гірники») - «Шальке-04»: Шальке стартував у чемпіонаті 3 2 поразок, а третій тур приніс «кнаппен» ще більще розчарування (football24. ua, 15.09.2018).

\section{5 Семантичні особливості португалізмів та інших нечастотних неозапозичень}

3-поміж неозапозичень із інших мов переважають португалізми, що засвідчує часткову прихильність уболівальників до португальського і бразильського футболу. Зазвичай ці одиниці метафорично описують національну команду, напр., селесао (порт. seleção «обрані») - іменником називають і збірну Португалії, і збірну Бразилії; пентакампеонес (порт. pentacampeо̃es «п’ятиразові чемпіони») - збірна Бразилії як 5-разовий чемпіон світу, а також номінують уболівальників: торсида (порт. torcida): Поєдинок 1/4 фіналу ЧС-2018 проти збірної Бельгії є 26-м на посаді для головного тренера «селесао» (football24. иа, 06.07.2018); Після десяти турів «пентакампеонес» мають у своєму активі 
21 очко (ua-football.com, 10.11.2016); Бразильська торсида не чекала нічого хорошого від виступу своєї збірної на чемпіонаті світу в Швеції (football. ua, 01.05.2018). Португалізм бісиклета (порт. bicicleta «удар в падінні через себе») через часте вживання став футбольним терміном і фактично має всі шанси потрапити до загальномовних словників: Бісиклета по-українськи. Кулач та його попередники (ua-football.com, 20.08.2018).

Зрідка в українському ФІД уживають португальські неозапозичення, що називають ліги африканських країн, напр., жирабола (порт. Girabola) - вища ліга Анголи, мокамбола / мосамбола (порт. Moçаmbola) - футбольна ліга Мозамбіку тощо. Однак такі інновації засвідчено лише в українськомовному сегменті «Вікіпедії» або на сайтах букмекерських контор і ресурсах, які «наживо» фіксують рахунки футбольних матчів, пор.: Останнього разу клуб покинув Мосамболу за підсумками сезону 2008 року (uk.wikipedia.org, 2016); АНГОЛА: Жирабола (myscore.ua, 2011-2019).

У футбольному лексиконі зафіксовано неозапозичення зі словенської мови любліанізм (словен. ljubljanizem), зумовлене прецедентною ситуацією. Інновацію утворено від топоніма Любляна, а в її основу покладено невдоволення вболівальників високими цінами за квитки на матч між збірними Словенії та України, що відбувся в Мариборі, тобто любліанізм - «те, що характерне для Любляни». Пор.: «Ідіотизм!» - пише одна вболівальниця на офіційній сторінці Федерації футболу Словенії в Facebook. «Любліанізм!» - іронічно відповідають їй, недвозначно натякаючи, щчо якщчо для столииі Любляни цее ще прийнятна изіна, то для провінційного Марібора - надто висока (football24. ua, 10.11.2015). Лексеми такого зразка мають фактично нульові шанси ввійти до загальномовного словника.

\section{3 Різномовні запозичення-контамінанти}

В українському ФІД засвідчено оригінальні зі структурно-семантичного погляду неозапозичення-контамінанти, твірні основи яких походять із різних мов. Зазвичай такі одиниці належать до онімної лексики, а їхня поява зумовлена футбольними прецедентними ситуаціями. Наприклад, інновація Неверкузен (Neverkusen - англ. never + нім. Leverkusen) - це прізвисько, яке вболівальники дали леверкузенському «Байєрові» після того, як команда мала всі шанси стати чемпіоном, але в підсумку фінішувала другою: Принаймні після иьього сезону «байєриі» отримали прізвисько «Неверкузен» (football24. ua, 01.05.2017). Неозапозичення Пікенбауер (Piquenbauer - ісп. Piqué + нім. Beckenbauer), утворене від прізвища іспанського футболіста Ж. Піке й німця Ф. Бакенбауера, стало назвою пива, пор.: «Пікенбауер», - таку марку напою випустила броварня Барселони (football24.ua, 06.07.2016). Контамінація $B a$ рез (Vahrez - англ. Vardy + фр. Mahrez) походить від прізвищ футболістів «Лестера» Дж. Варді й Р. Мареза, які на матч із «Челсі» взули бутси з таким написом: На матч проти «Челсі» у 38 турі АПЛ лідери «Лестера» Ріяд Марез та Джеймі Варді вирішили одягнути бутси з однаковим написом «Варез», щзо символізуватиме їхню дружбу (football24.ua, 14.05.2016). Після того, як Є. Коноплянка провів вдалу гру з «Фрайбургом» і поцілував камеру, коли 
забив гол, німецький «Bild» сконструював прізвисько KNUTSCHERplyanka (нім. Knutscher «поцілунок» і Konoplyanka), яке транслітерували українські журналісти: У своєму заголовку ие ЗМІ назвало нашого гравия «Кнучерплянка» (champion.com.ua, 20.12.2016). Звісно, що ці номінації вимагають від читача фонових знань, а також відповідної лінгвістичної компетентності.

Зрідка у футбольному дискурсі натрапляємо на неозапозичення, утворені зрощеннєвим способом, причому твірні основи походять із різних мов. Приміром, інновацією гегенпресинг (нім. gegen «проти» й англ. pressing «тиск») позначають тактику німецького тренера Ю. Клоппа, згідно з якою команда, утративши м'яч, намагається швидко повернути його: Його команди яскраві, в них реалізовується вже знаменитий «гегенпресинг» (football24.ua, 02.05.2018). Отже, контамінації засвідчують взаємодію різних мовних систем у творенні футбольного дискурсу.

\section{4 Пристосування неозапозичень до системи української мови}

Усі неозапозичення поступово пристосовуються до граматичної системи української мови.

Сучасні науковці стверджують, що потреба якомога точніше, зручніше позначити нове поняття або реалію призводить до з'яви номінацій-конкурентів, тобто «номінацій того самого об’єкта з різними формою та/або змістом, 3 різним стилістичним чи комунікативно-прагматичним потенціалом» (Карпіловська, Кислюк, Клименко та ін. 2017: 41). Причому конкурувати між собою можуть як лексеми, утворені на питомому мовному грунті, так і іншомовні запозичення. Л. М. Підкуймуха, аналізуючи львівське койне першої половини ХX ст., стверджує, що футбольні поняття, створені за словотвірними моделями української мови, не витримали конкурування з англізмами або їх свідомо усунули з мовлення українців як вияви національної словотворчості. Як приклади дослідниця наводить лексеми лучник - «нападник, форвард», головкувати - «відбивати м'яч головою», відсторона - «офсайд; положення поза грою»; наріжняк - «кутовий удар» тощо (Підкуймуха 2016: 10-11).

У сучасному ФІД неозапозичення конкурують між собою або з українським відповідником чи раніше запозиченим англізмом. Виокремлюємо граматичну, орфографічну, графічну й лексичну конкуренцію.

\section{1 Граматичне конкурування}

Граматичними конкурентами насамперед $є$ іспанізми у формі однини (напр., блауграна) і множини (напр., блаугранас). Пор.: ... «блауграна» може просто викупити контракт форварда, клаусула якого на даний момент становить 100 млн євро (ua-football.com, 10.10.2017); Наставник блаугранас поділився очікуваннями перед каталонським дербі (ua-football.com, 07.12.2018). Трапляються випадки, коли іспанські запозичення набувають відмінкової парадигми української мови, як-от: Космічний футбол від «блауграни» (sportanalytic.com, 20.08.2012); Контракт Дані із «блауграною» закінчується наступного року... 
(football24.ua, 18.08.2014). Окрім того, у футбольному дискурсі засвідчено лексичний кореферент синьо-гранатові: Синьо-гранатові постараються niдписати французького гравця (ua-football.com, 27.07.2018). Тобто ідеться про чотири компоненти: «іспанізм в однині» / «іспанізм у множині» / «граматично пристосований іспанізм» / «українськомовна калька».

Конкуренцію форм однини та множини спостерігаємо й у неозапозиченнях італійського походження, напр., лащзіале - лаціалі. В українському ФІД ці лексеми вживають безвідносно до первинних грамем числа в мові-джерелі, пор.: ...ххоча до иъього на «Стадіо Олімпіко» перемогу святкували саме «лаuіале» (footballua.tv, 19.12.2014); Лачіале вийшов навіврезервним складом... (ua-football.com, 28.11.2015); ...лаціалі будуть діяти агресивно в виїзному матчі 1/8 Ліги Свропи з Динамо (ua-football.com, 15.03.2018).

У множинних формах найменувань, утворених від назви команди за допомогою суфікса -isti (напр., milanista - milanisti), спостерігаємо заміну італійського закінчення - $i$ співзвучною флексією - $u$, що адаптує ці лексеми до відмінкової парадигми української мови, пор.: “Міланіста» Давіде Ді Дженнаро виграв у найлютімого ворога (ua-football.com, 17.10.2016); Міланісті просто були сильніші за суперника (football.hiblogger.net, 08.05.2010) - Зробити пропозицію по гравцюю міланісти хочуть в літнє трансферне вікно (ua-football. com, 19.01.2017). Окрім того, у формах однини такі неозапозичення не мають однієї моделі словозміни. Їх відмінюють або як іменники чоловічого (Бокетті до кіния сезону став «міланістом» (football24.ua, 28.01.2015)), або жіночого (Робінью залишається «міланістою» (football24.ua, 19.07.2013); Радий, що він став "романістою» (ua-football.com, 08.09.2017)) роду, що засвідчує неоднакове сприймання цих інновацій у лексичній системі української мови й визначення родової належності за семантичним або формально-граматичним принципом. Хоча останнім часом помітна тенденція до маскулінізації й у формах називного відмінка чоловічого роду їх уживають без притаманного італійській мові закінчення - : Востаннє ворота каталонців на «Камп Ноу» вразив міланіст Тьяго Сілва (tsn.ua, 05.01.2012); «Гранатовий» Максі Лопес, в якого «інтеріст» Ікарді відбив наречену, помстився гольовим пасом (football24.ua, 25.01.2015). Це свідчить, що граматичну конкуренцію виграє́ форма чоловічого роду з нульовим закінченням, характерна для питомих утворень, пор., динамівець, карпатівець, дніпрянин, барселонець, реалівецьь.

\section{2 Орфографічне конкурування}

Потрапляючи до українського футбольного лексикону, неозапозичення зазнають правописної адаптації, що зумовлює з'яву орфографічних конкурентів. Це спричинено такими особливостями:

a) розбіжностями щодо застосування «правила дев'ятки» до всіх загальних назв іншомовного походження: тріденте / триденте, мадридиста / мадрідіста / мадридіста, еластіко / еластико, бісиклета / бісіклета;

б) використанням фонетичного чи морфологічного принципу транслітерації: суппортер / саппортер, мециала / медзала, латікс / летікс; 
в) написанням італізмів із подвоєнням і без нього: россонері / росонерi, джалороссі / джалоросі, мещиала / мецала, тифозерія / тіфозерія / тіффозерія;

г) різним написанням складних англізмів: клін-щит / кліншит, бокс-ту-бокс / бокс ту бокс / бокстубокс, матчдей / матч-дей, лонг-бол / лонгбол.

Однак із-поміж орфографічних конкурентів переважать інновації, які не суперечать чинним правописним нормам, пор.: Ібрагімович оцінив би таку бісиклету... (champion.com.ua, 26.08.2016); «Рома» - лідер чемпіонату, яка показує доволі змістовний футбол і вселяє надї своїй тифозерії (ua-football. com, 22.09.2013); Мадридська ностальгія. 5:0 в Ель-Класико для Реала (иаfootball.com, 26.10.2018).

\section{3 Графічні конкуренти}

До графічних конкурентів зараховуємо одиниці, передані різними графічними системами - латиницею і кирилицею. Безперечно, що в сучасному ФІД здебільшого використовують транслітеровані неозапозичення, однак зрідка натрапляємо на іншомовні вкраплення - слова, уживані у звуковій і графічній формі мови-джерела без адаптування до системи української мови (Клименко, Карпіловська, Кислюк 2008: 19), як-от: La blanquirroja не відчували радість від забитого гола на Мундіалі (ua-football.com, 26.06.2018); Інше питання, щьо Squadra Azzиrra зараз далека від своєї оптимальної форми... (ua-football.com, 28.05.2018), пор.: Так, щу СкуадраАдзура ще не раз носа втре (fckarpaty.com. ua, 02.06.2011) тощо.

\section{4 Лексичні конкуренти}

Найбільшу кількість неозапозичень становлять лексичні конкуренти. Зазвичай такі одиниці розширюють синонімні ряди української мови, окремі з них мають обмежений функційний потенціал. Конкурувати між собою можуть як інновації іншомовного походження, так і їхні українські відповідники (див. приклади в табл.).

\begin{tabular}{|l|l|l|l|l|}
\hline Українська & Англійська & Іспанська & Італійська & Німецька \\
\hline наставник & тренер, коуч & ентренадор & алленаторе & \\
\hline нападник & форвард & делантеро & атаканте & \\
\hline ґесятка» & плеймейкер, диспетчер & реджиста & енганче & шпільмахер \\
\hline воротар & голкіпер & портеро & портьєрі & \\
\hline півзахисник & хавбек & центрокампіста & чентрокампіста & \\
\hline уболівальники & фанати & інчас, інчада & тифозі & \\
\hline
\end{tabular}


3-поміж лексичних конкурентів, у сучасному ФІД переважають власне українські утворення, а також слова, раніше запозичені з англійської мови. Можна стверджувати про мирне співіснування цих лексем і вживання їх як синонімів задля уникнення тавтології, пор.: Украӥнський форвард виявився кращим, ніж легендарний іспанський нападник (m.znaj.ua, 28.06.2017); Український воротар підтримав голкіпера Ліверпуля після провалу у фіналі ЛЧ (champion.com.ua, 27.05.2018). Неозапозичення з італійської, іспанської та інших мов здебільшого ідентифікують осіб за походженням або належністю до національного чемпіонату, програючи конкуренцію англізмам і українським лексемам: Центральний півзахисник, або, як прийнято казати на Піренеях, иентрокампіста, бігав у “Сельті», яка лише розпочинала свій шлях зі Сегунди у Прімеру (football24.ua, 14.12.2012).

\section{5 Висновки}

Отже, до українського ФІД найчастіше проникають неозапозичення з іспанської, італійської й англійської мов, що зумовлено високим рівнем розвитку футболу відповідних країн. Здебільшого іспанізми й італізми мотивовано кольором форми, у якій грає команда, або утворено від назви міста, яке вона представляє. На сучасному етапі іспанські й італійські неозапозичення зазвичай слугують національними ідентифікаторами, хоча подекуди розширюють своє функційне навантаження, набуваючи узагальненої семантики.

На відміну від загальномовних тенденцій, у ФІД англійські неозапозичення кількісно поступаються іспанізмам й італізмам, оскільки багато англізмів раніше втратили свій неологічний статус і перейшли до узуальних термінів. Новітні лексеми англійського походження мають уточнювальну семантику, конкретизуючи функції гравців на полі, типи ударів по м'ячу, різновиди часових проміжків тощо. Германізми й португалізми зазвичай метафорично номінують національні збірні, зрідка - команди або ліги. Прикладом структурно-семантичної взаємодії різних мов слугують контамінановані неозапозичення, мотивовані футбольними прецедентними ситуаціями, для розуміння яких потрібні фонові знання.

У ФІД неозапозичення конкурують на граматичному, правописному та графічному рівнях, однак перевагу мають ті інновації, що не суперечать чинним мовним нормам. Лексичні конкуренти мирно співіснують у сучасному футбольному лексиконі, розширюючи синонімні ряди української мови, хоча неозапозичення іспанського й італійського походження здебільшого залишаються виразниками національної ідентичності.

\section{ЛІТЕРАТУРА}

Катерина ГОРОДЕНСЬКА, 2009: Нові запозичення і новотвори на тлі фонетичної та словотвірної підсистем української літературної мови. Науковий часопис Наиіонального педагогічного університету імені М. П. Драгоманова. Серія 10. Проблеми граматики і лексикології української мови, вип. 5, 3-7. 
Євгенія КАРПІЛОВСЬКА, Лариса КИСЛЮК, Ніна КЛИМЕНКО та ін., 2017: Вплив суспільних змін на розвиток украӥнської мови. Київ: ВД Дмитра Бураго.

Ніна КЛИМЕНКО, Євгенія КАРПІЛОВСЬКА, Лариса КИСЛЮК, 2008: Динамічні процеси в сучасному украӥнському лексиконі. Київ: ВД Дмитра Бураго.

Ірина КОРОБОВА, 2017: Семантичне та словотвірне освоєння новітніх запозичень в украӥнській мові: дисертація. Київ - Запоріжжя.

Віталій МАКСИМЧУК, 2018: Префіксоїди супер- і мега- як засоби оновлення футбольного лексикону: українсько-польські паралелі. Studia z Filologii Polskiej i Stowiańskiej $53,294-228$.

НС3, 2008 = Нові слова та значення: словник. Укл. Людмила Туровська, Лада Василькова. Київ: Довіра.

Людмила ПІДКУЙМУХА, 2016: Лексичний склад західноукраїнського варіанта літературної мови (на матеріалі художніх текстів львівських письменників першої пол. $X X \mathrm{~cm}$.): автореферат. Київ.

Наталія СОВТИС, 2013: Критерії виділення польських запозичень в українській мові. Наукові записки Національного університету «Острозька академія», вип. 34, 227-229.

Олександр СТИШОВ, 2017: Нові іншомовні слова в українськомовних ЗМІ початку ХХІ ст. Філологічні студї̈, вип. 9, 66-76.

Юрій СТРУГАНЕЦЬ, 2015: Процес іншомовних запозичень у футбольній лексиці сучасної української мови. Наукові записки Начіонального університету «Острозька академія», вип. 57, 116-121.

\section{NOVE PREVZETE BESEDE V UKRAJINSKEM NOGOMETNEM SPLETNEM DISKURZU}

V članku so analizirane nove prevzete besede v sodobnem ukrajinskem nogometnem spletnem diskurzu. Analiza španskih, italijanskih, angleških, nemških in drugih prevzetih besed je potekala na podlagi različnih kriterijev, kot so leksikografski, kronološki, funkcijski in semantični.

Ugotovljeno je bilo, da španske, italijanske in angleške inovacije v ukrajinski nogometni spletni diskurz najpogosteje prodrejo zaradi visoke razvitosti nogometa $\mathrm{v}$ teh državah. Španske in italijanske inovacije so večinoma motivirane z barvo kluba ali imenom njegovega domačega kraja. Španske in italijanske inovacije so nacionalni identifikatorji, včasih pa razvijejo posplošeno semantiko, npr. портеро, енганче, атаканте.

$\mathrm{V}$ nogometnem spletnem diskurzu je besed, prevzetih iz angleščine, manj od tistih, ki so prevzete iz španščine in italijanščine, ker so številne angleške besede izgubile status neologizmov in so postale del splošnega izrazja. Angleške leksikalne novosti poimenujejo vloge nogometašev na igrišču (вінгер, вінгбек), vrste udarcev z žogo (тандерболт, лонгбол), časovna obdobja (вінстрік, матчдей) itn. Nemške inovacije nemško reprezentanco in ekipe zvezne lige poimenujejo po njihovi barvi ali vzdevkih. Portugalske leksikalne novosti prevladujejo nad izposojenkami iz drugih jezikov, kar delno nakazuje predanost navijačev portugalskemu in brazilskemu nogometu. Ti leksemi običajno metaforično opisujejo nacionalne ekipe (селесао, пентакампеонес) ali lige afriških držav (жирабола, мокамбола). Primer strukturno-pomenske interakcije različnih jezikov so kontaminirane prevzete besede, katerih nastanek spodbujajo tipične nogometne okoliščine: Пікенбауер, Варез, Кнучерплянка. Za razumevanje teh leksemov mora bralec poznati ozadje, imeti pa mora tudi določene jezikovne kompetence.

V ukrajinskem nogometnem spletnem diskurzu so nove prevzete besede v konkurenčnem odnosu na slovnični, pravopisni in grafični ravni, prevladajo pa tiste inovacije, ki ne nasprotujejo 
obstoječi jezikovni normi, npr. бісиклета, тифозерія, Ель-Класико. Ne glede na to lahko zaključimo, da leksikalne dvojnice v ukrajinščini soobstajajo in širijo njegovo sinonimijo: наставник (Ukrainian) - тренер, коуч (English) - ентренадор (Spanish) - алленаторе (Italian); воротар (Ukrainian) - голкіпер (English) - портеро (Spanish) - портьєрі (Italian). 


\section{Ob sedemdesetletnici dopisnega člana Slovenske akademije znanosti in umetnosti dr. Ludvika Karničarja}

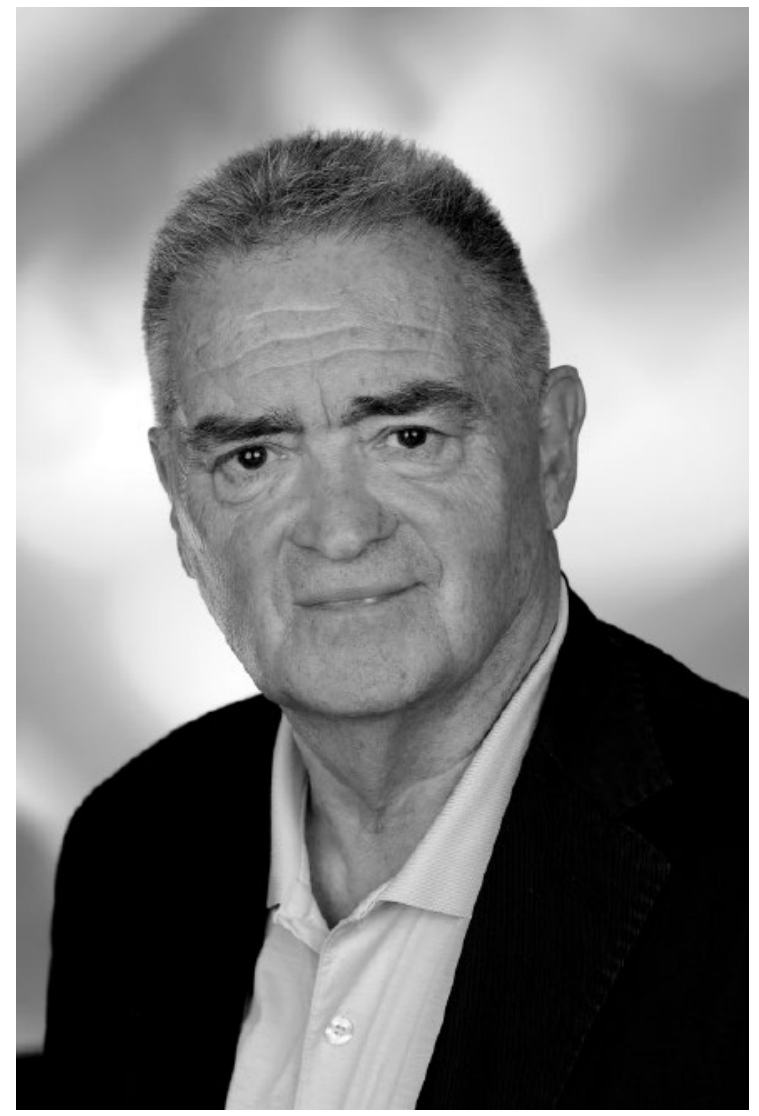

23. avgusta letos je bila ob bistrem potoku na avstrijskem Koroškem, pri Kovaču, v slovenski gostilni pod Obirjem, posebna priložnost - naš spoštovani in dragi kolega, priznani slavist, ugledni kulturolog, upokojeni profesor graške slovenistike in dopisni član SAZU, v domačem obirskem okolju in domači družini vedno 
dobrodošli in priljubljeni Ludvik Karničar je v krogu domačih, prijateljev in sodelavcev praznoval sedemdeseti rojstni dan. Vsi zbrani smo mu ob jubileju iskreno čestitali in mu zaželeli: »Še na mnogaja leta! Dragi Ludvik, Bog Vas živi!«

Ob taki obletnici, v najboljših letih življenja, ne zadoščajo le običajne besede, ki z vseh strani odmevajo in se ponavljajo. Potrebno je povedati nekaj več. Potrebno se je ozreti nazaj, na prehojeno pot, se zamisliti in spomniti, kako je naš jubilant sam premagoval številne ovire in napore, da je kot pokončni, zavedni in verni Slovenec dosegal svoje cilje, ki so ga iz topline domače rojstne hiše staršev, bratov, sester, izvabili v drugačna, neobčutljiva okolja, v širni evropski svet učenosti, znanosti in kulture. To bi nam znal in mogel le on sam slikovito, s kancem humorja, s pogledom iz obirskih višin na zamegljene nižave, izčrpno odkrivati in komentirati.

Jaz se bom omejila le na njegovo študijsko obdobje, na začetke njegovega uspešnega strokovnega vzpona pri študiju slavistike in prevajalstva na graški Univerzi. Srečala sem ga leta 1977/78 kot gostujoča lektorica slovenskega jezika na Inštitutu za slavistiko v Gradcu. Tedaj sem že imela za seboj neko lastno spoznanje o koroških Slovencih kot pripadnikih manjšine v Avstriji. V tem času mi, slavisti, pa tudi drugi slovenski državljani tedanje države (SFRJ) nismo skoraj nič vedeli o slovenskih rojakih »čez mejo«, saj neuradnih stikov z matičnim narodom skoraj ni bilo, če so bili prikriti, so pa bili zelo nevarni ...

Ko sem bila po smrti dr. Pivka, dunajskega univerzitetnega učitelja za slovenščino, na povabilo tamkajšnjega Inštituta za slovansko filologijo leta 1967 do konca leta 1968 (za tri semestre) z ljubljanskega Oddelka za slovanske jezike in književnosti poslana na Dunaj, da bi premostila časovno vrzel do zaključenega doktorskega študija dr. Pavla Zdovca (po letu 1969 je bil na to mesto učitelja za slovenski jezik uradno nameščen), nisem o svojih slušateljih, večinoma abiturientih celovške Zvezne gimnazije za Slovence, vedela ničesar. Tudi tega ne, kdo je tolikokrat s spoštovanjem omenjani dr. Jožko Tischler. Nekaj časa je bil med menoj in slušatelji neprodoren zid. Komaj sem govorila. Hromili so me njihovi nezaupljivi, skoraj porogljivi pogledi, končno pa mi je le uspelo najti primerne besede, ki so nas spravile v smeh. Tako smo se prepoznali, spoznali smo, da smo vsi eno, da smo vsi Slovenci - in postali smo prijatelji. Obiskovala sem z njimi tedaj zelo dejavni Klub koroških Slovencev na Dunaju in tako spoznavala takratne travme pravzaprav v čudni izolaciji živečih koroških Slovencev ... Zelo so me prizadele! Izdajali in pisali so v tem času svojo leposlovno revijo Mladje, na Koroškem se je začenjal boj za table s slovenskimi krajevnimi imeni in dostikrat sem slišala boleč očitek, kako smo mi, matični narod, nanje "pozabili«.

Kar sem mogla, sem napravila po vrnitvi v Ljubljano, da bi se koroškim študentom vsaj strokovne poti na naš Oddelek v Ljubljano odprle. In res so od takrat dalje posamezni slušatelji, slavisti in zgodovinarji, vsako leto prihajali na ljubljanski Poletni seminar za tuje slaviste na naš Oddelek za slovanske jezike in književnosti na Filozofski fakulteti (osnovan je bil 1. 1966). To seveda ni bilo ne vem kaj, vendar je bil »led prebit« in stiki s slavisti, zgodovinarji in geografi so oživeli (zlasti po zaslugi dr. Boga Grafenauerja in dr. Vlada Klemenčiča, ki sta bila s Koroško tudi sorodstveno povezana). Dunajski Klub koroških Slovencev je obiskal tedaj tudi priznani, pogumni novinar dnevnika Delo, pesnik in pisatelj Jože Snoj, ki je za slovensko javnost prvi o Klubu obelodanil več tehtnih prispevkov. 
Na Filozofski fakulteti pa je bila osnovana tudi Komisija za stike s Slovenci v zamejstvu. Vsako leto so med Božičem in novim letom v Celovcu potekali Koroški kulturni dnevi s predavanji na aktualne teme, ki so jih pripravili tako koroški kot ljubljanski predavatelji.

Ko sem leta 1977/78, že kot docentka, v isti vlogi za eno leto prišla na Inštitut za slavistiko v Gradec, sem v tamkajšnjem okolju že poznala predstojnika, dr. Stanislava Hafnerja, in tedaj še asistenta dr. Erika Prunča, srečala sem pa tudi slušatelja diplomanta, gospoda Ludvika. Zbiral in pripravljal je narečno gradivo z obirskega območja za svojo disertacijo. Spominjam se, da sva skupaj poslušala, zapisovala vsebinsko pretresljive narečne posnetke. Seznanjala sem ga s transkripcijskimi pravili zapisovanja narečnih glasov, uveljavljenih pri delu za Slovenski in Slovanski lingvistični atlas (SLA in OLA), ki sta takrat nastajala in sem pri tem delu sodelovala.

V spominu mi je ostala zlasti posneta zgodba o nekdanjem obirskem vojaku, ki je bil v drugi svetovni vojni na ruski fronti nekje v Ukrajini. V četi je bil za kuharja in k njemu se je priplazil nek sestradani otrok, ki se ni dal odgnati. Tvegal je in mu na skrivaj dajal jesti. Potem je prišel ukaz za umik. Otroka je odpeljal na samotno jaso in ga tam pustil samega ... Ni mogel drugače! Še ko se je po tolikih letih spominjal tega pretresljivega dogodka, se je jokal ... Tako sem odkrila mehkobo koroške duše, njegovo sočutje, dobrosrčnost, veliko trpljenje in - tveganje! Ne le njegovo, marveč mnogih koroških rojakov, ki so se morali proti svoji volji podrejati in uklanjati nesprejemljivim ukazom ... Tako sem dojela, kaj pomeni neprestano »duhovno nasilje« nad slovenskimi deželani Koroške. Skušala sem doumeti, kaj pomeni biti dan na dan na preizkušnji: ali zatajiti ali izpostaviti svojo materinščino, svojo etnično pripadnost, svojo identiteto, saj to ni ostajalo brez posledic! Ali ne pomenijo takšne vsakdanje razmere za človeka trajno »lomljenje hrbtenice«? Res! Koroških Slovencev je, na žalost, vedno manj, so pa vsi pokončni, preizkušeni, zavedni. In vrednote prednikov so jim dragocene, svete! Lahko se mi od njih učimo! Zato sem slovenske koroške rojake vedno na poseben način dobronamerno spremljala, jih skušala razumeti in ohranjati z njimi stike, tako tudi z našim jubilantom.

Ko sem v Gradcu videla, da slušatelj doktorand Ludvik poleg svojega raziskovalnega dela opravlja pod »nujno« še druge obveznosti, sem slutila, da obojemu ne bo kos. Predlagala sem predstojniku, prof. Hafnerju, da bi njegov doktorand s štipendijo za eno leto odšel v Ljubljano. To se je uresničilo in res je v Ljubljani v miru dokončal disertacijo ter dosegel doktorat znanosti. Disertacija Der Obir-Dialekt in Kärnten. Die Mundart von Ebriach/Obirsko im Vergleich mit den Nachbarmundart von Zell/Sele im Trögern/Korte pa je kasneje (leta 1990) izšla pri Avstrijski akademiji znanosti kot monografija o obirskem dialektu. Delo trajne znanstvene vrednosti, ki je gospoda dr. Ludvika Karničarja usposobilo za sodelovanje pri znamenitem Projektu za inventarizacijo leksike slovenskega ljudskega jezika oz. govorov Koroške, ki sta ga jezikoslovno zelo inovativno in znanstveno zahtevno zasnovala že pokojna dr. S. Hafner in dr. E. Prunč. Tovrstno raziskovalno delo in dejavno, trajno praktično udejstvovanje na področju prevajalstva sta dr. Karničarju zagotovila asistentsko mesto oz. sodelovanje na Avstrijskem inštitutu za vzhodnoevropsko in jugovzhodnoevropsko zgodovino (od leta 1986 do 1989), po 
odhodu dr. Erika Prunča na Inštitut za translatologijo pa na Inštitutu za slavistiko tudi nadaljnjo slavistično univerzitetno kariero - od asistenta do izrednega univerzitetnega profesorja, vse do upokojitve pred petimi leti. Za njim so se perspektive za slovenistiko na graški Univerzi, žal, zožile.

Dr. Karničar je bil »gonilna sila« Projekta za inventarizacijo slovenskega besedišča, pri katerem je končno ostal sam. Zelo se je poglabljal v slovensko besedišče Koroške v sočasnem in zgodovinskem uvidu. »Obrnil« je tudi Gutsmanov Deutsch-Windisches Wörterbuch (iz leta 1789), tj. izpostavil slovenske geselske besede, pripravil, uredil in pri dunajski Akademiji znanosti v letih 1982-2012 izdal na podlagi zbranega slovenskega besedja iz Projekta sedem zvezkov Tesaurusa (od A do Mi), Thesaurus der slowenischen Volkssprache in Kärnten, Alfabetarij k Tezauru slovenskega ljudskega jezika na Koroškem pa je sestavil v sodelovanju z dr. Andrejko Žejn in ga je lani (leta 2018) izdala Slovenska akademija znanosti in umetnosti (SAZU) v Ljubljani.

Kot razgledan in praktični prevajalec vseh zvrsti slovenskega jezika (tako publicističnih, pravnih kot ekonomskih) je sodeloval tudi pri Pravnem nemško-slovenskem (leta 1989) in slovensko-nemškem slovarju dr. Pavla Apovnika (leta 1996), delu izjemne vrednosti, in še bi lahko naštevali.

Napisal je vrsto tehtnih sociolingvističnih razprav, ki so izšle v nemških in slovenskih strokovnih zbornikih. Z izjemnim posluhom za jezikoslovna, zgodovinska in kulturološka vprašanja je v Gradcu organiziral vrsto mednarodnih simpozijev in srečanj, spominskih prireditev. Tako je na palači nekdanje jezuitske univerze oskrbel tudi spominsko ploščo prvemu učitelju slovenščine na graški stolici, Janezu Nepomuku Primicu (leta 2011). Organiziral je vsakoletne kulturološke ekskurzije $\mathrm{s}$ študenti v slovenski in slovanski prostor in $\mathrm{z}$ rojaki poromal v slovenska božjepotna središča. Z eno besedo: bil je vedno, in ostal, vsestransko komunikativna osebnost, »z dušo« na vseh področjih delovanja. Obvlada vsak »govorni položaj«! Mislim, da nima sovražnikov, ne med rojaki, ne med nemškimi sodeželani, pa tudi ne med ženskami ...

Ob svojem slovenističnem pedagoškem delu s študenti na graški fakulteti se je potrjeval s strokovnim slovenističnim in slavističnim znanjem (knjižna slovenščina, ruščina, hrvaščina), uporabljal pa je tudi svoje bogate izkušnje iz prevajalstva (odlikuje ga odlično znanje glavnih evropskih jezikov) in tako bistveno razširjal študijsko obzorje slušateljev, ki jih je znal pritegniti s svojo širino, duhovitostjo, vedrino in človeško toplino. Kot slavist-slovenist je vedno izvirno, s posluhom za sodobna družbena vprašanja koroškega dvojezičnega prostora, izpeljeval svoje naloge in svoje zamisli.

Vendar slovenistika s sociolingvistiko in z domoznanstvom ni bila edino njegovo ustvarjalno področje. Izvrstno je te vednosti interdisciplinarno povezoval z glasbo. V ta sklop sodi njegovo sodelovanje z glasbenim etnologom dr. Engelbertom Logarjem. Skupaj sta uredila in izdala do leta 2019 že 44 zvezkov gradiva serije Pesmi in glasba z južne Koroške. Z osebnim, občutenim vrhunskim petjem, saj je prejel tudi ta žlahten božji dar, pa je povsod, kjer je zapel, poskrbel za dobro voljo in s tem prispeval k utrjevanju trajnih prijateljskih vezi - tako na Koroškem kot v Sloveniji, bodisi na glasbeno-akademski ali na ljudski ravni ... Samo pomislimo, kaj pomeni peljati se, dokler je bil odgovoren za zbor, vsak teden iz Gradca na 
Obirsko, da lahko v župnijski cerkvi zapoje pri slovenski nedeljski maši! Kakšna zvestoba veri, maternemu jeziku in rojstnemu kraju!

Svojo predanost glasbi in petju je jubilant potrdil tudi s tem, da je na graškem pokopališču St. Leonhard skupaj z gospodom I. Martelancem dal postaviti nov nagrobnik prvemu profesorju slovenistu graške univerze, dr. Karlu Štreklju, zaslužnemu, načrtnemu zbiralcu in izdajatelju Slovenskih narodnih pesmi (leta 2014), za tem pa na pokopališču St. Peter poskrbel še za postavitev novega spomenika Slovencu, zdravniku, skladatelju in glasbeniku dr. Benjaminu Ipavcu, v sodobnosti pri nas preveč pozabljenemu ustvarjalcu slovenske domovinske zborovske pesmi 19. stoletja (leta 2018).

Gospod dr. Ludvik Karničar je bil leta 2017 za svoje zaslužno znanstveno in požrtvovalno kulturološko delo imenovan za dopisnega člana Slovenske akademije znanosti in umetnosti. Istega leta mu je predsednik Republike Slovenije Borut Pahor podelil red za zasluge, in sicer za trud pri ohranjanju slovenistične tradicije na graški univerzi. Leta 2017 je od Občine Komen prejel tudi Štrekljevo nagrado. To podeljujejo "posameznikom ali skupinam za življenjsko delo ali izjemne dosežke na področju zbiranja in ohranjanja slovenskega ljudskega blaga v besedi in pesmi«.

Tak je njegov presenetljivi družbeni vzpon od obirskega šolarja, ki se je (na vse pretege, kot je sam dejal) branil šole, do znanstvenika-akademika! Pa ne samo akademika, marveč tudi plemenitega, dobrosrčnega človeka, ki zna mirno nositi tudi tegobe življenja, kot je omajano zdravje. Pravi, da je slovenstvo nekaj edinstvenega, izbranega, podobno kot judovstvo, slovenščina pa kot hebrejščina arhaična in originalna; zato naj bi bila vsem, ki nase kaj dajo, srčna zadeva, vredna najglobljega spoštovanja!

Tak kot je, ostaja zgled rojakom na Koroškem in vsem nam Slovencem. Za vse mu gre čast in zahvala!

Ljubljana-Obirsko, 23. 8. 2019

Martina Orožen 


\title{
Zinka Zorko
}

\author{
(24. februar 1936-22. marec 2019)
}

\section{BESEDE SLOVESA}

Draga Zinka, moja dolgoletna strokovna sopotnica!

V svečani dvorani Slovenske akademije znanosti in umetnosti sva se ob Tvoji 80-letnici zadnjič srečali. Dobro razpoložena strokovna druščina se je po svečanem kosilu optimistično poslavljala od Tebe. Odhajala si naslednje dni na operacijo kolkov. Zaželela sem Ti uspešno okrevanje, saj sem imela to izkušnjo že za seboj. Kdo bi takrat slutil, da je bilo to naše srečanje zadnje, da je bilo to naše resnično slovo ...

Okrevanje ni potekalo po pričakovanjih; pojavljali so se še dodatni zapleti, vendar smo bili prepričani, da jih boš premagala. Za novo leto letos si me poklicala. Voščili sva si vse dobro. Začela si govoriti o mojem delu in mi izražati priznanja. Bila sem v zadregi in pravzaprav začudena - kaj to pomeni? Zdaj vem. Slutnja. Želela si mi še to povedati ... Kmalu zatem, marca, pa nas je presenetila nepojmljiva vest o Tvojem odhodu. Tvoj zvonki glas je utihnil. Odšla si iz ljubečega družinskega in strokovnega kroga. Odšla, nepovratno, odšla in pustila vse za seboj! In zdaj že uživaš blaženi, zasluženi večni pokoj - tam v prelepi rodni koroški deželi, ki si ji bila vse življenje neizmerno zvesta ...

Zdi se, kot da si nekam nujno odpotovala in se bomo čez čas spet videli! A tokrat si odšla nepreklicno, vendar zame, za nas, ki smo Te poznali, spoštovali, ostala živa! Živa vse od dne, ko sem te na dialektološkem seminarju Tvojega cenjenega mentorja, akademika prof. dr. Tineta Logarja, prvič srečala. Svetlolaska je pripovedovala zabavno narečno zgodbo iz rodnega okolja o švercanju saharina ali petroleja v »stari Jugoslaviji« ob koroško-avstrijski meji. Še zdaj slišim živahen, nekoliko sekajoč govorni ritem Tvoje rodne koroške govorice. Po diplomi si na profesorjevo žalost, rad bi Te obdržal, sprejel za asistentko, odšla na gimnazijo na Ravne na Koroškem, pa tudi družino si si ustvarila. Čez nekaj let pa si se ponovno oglasila na Katedri za zgodovino in dialektologijo slovenskega jezika, polna raziskovalne vneme in navdušenja. Ob svojih družinskih in pedagoških obveznostih, mislim, da že v Mariboru, si najprej zaključila magisterij, nato še doktorat o govorih Dravske doline. Koroška narečna skupina je tako dobila tehtno raziskovalko, kot pred leti Notranjska z Dolenjsko dr. Jakoba Riglerja. Veliko veselje in zadoščenje mentorja Tineta Logarja, ki je tako vzgojil zgledno samostojno raziskovalko - in naslednico, saj ga je po upokojitvi leta 1985 dobro desetletje uspešno nadomeščala, vse do strokovne zrelosti druge njegove specializantke, dialektologinje, dr. Vere Smole. Vsak teden si pripotovala iz Maribora ... Ob svojem pedagoškem, 
znanstvenoraziskovalnem, terenskem delu na Pedagoški fakulteti v Mariboru si bila trajno vpeta še v strokovno-organizacijske obveznosti, saj se je vsa sedemdeseta in osemdeseta leta preteklega stoletja mariborska Pedagoška fakulteta preobražala v Filozofsko fakulteto. Pogumno, daljnoročno zazrta v prihodnost mariborske univerze, si prevzemala vso težo odgovornosti pri snovanju Oddelka za slovanske jezike in književnostjo na Pedagoški fakulteti Univerze v Mariboru. Koliko besed nezaupanja je bilo takrat slišati po Ljubljani ... V tistih letih sva se skupaj zavzemali za vzgojo potrebnih kadrov s področja dialektologije in zgodovinskega jezikovnega razvoja, vse v dobri veri, da bo čez 10 let na Filozofski fakulteti v Mariboru že vse drugače. Nisva se zmotili. Čas je tekel neizmerno hitro in mariborska slovenistika se je z mladimi močmi uspešno osamosvojila, okrepila, zaživela. Raziskovalno delo se je razširilo v panonski slovenski narečni prostor, slovenistika pa se je obogatila z novimi jezikoslovnimi spoznanji o Prlekiji, o Slovenskih goricah in Prekmurju s Porabjem - v sočasnem in zgodovinskem uvidu. V narodnostnem pogledu so bili po Tvojih zaslugah, izjemni spretnosti, posebej pomembni oživljeni sosedski stiki s koroškimi in štajerskimi Slovenci prek meje, posebej pa s porabskimi Slovenci na Madžarskem kot tudi strokovni stiki z Visoko šolo v Sombotelu in slavistiko na Univerzi v Budimpešti. Povsod si bila prisotna in vztrajno dejavna. Dokaz temu so med drugim tudi mednarodni dialektološki simpoziji, ki so pod Tvojim vodstvom zaživeli v Mariboru. V prijetnem kolegialnem ozračju smo obhajali 80-letnico Tvojega mentorja, akademika Tineta Logarja, spominski simpozij za pokojnim profesorjem Jakobom Riglerjem, mojo 70-letnico, Tvojo 70-letnico in odhod v formali pokoj in druge simpozije, saj si delala z vsemi močmi še naprej - kot mentorica, organizatorica, kot predavateljica, prodekanka, dolga leta kot prorektorica Univerze v Mariboru itd. Organizirala si tudi dialektološke tabore v Porabju. Kako hitro smo se zbližali z domačini! »Slavci so prišli, Slavci so prišli«, je ganjeno vzklikala stara ženička. Bilo je nepozabno, ko je v svoji mali izbici z okenske police vzela oguljeno Küzmičevo Knigo molitveno v stari knjižni prekmurščini, s sosedo pa sta nam skupaj zmolili, ne povedali, po domače očenaš: »Oča naš, šteri si vu nebesaj, sveti se ime tvoje ...«V vasici Verici pa smo obiskali domačega lončarja, da bi spoznali njegovo izvirno terminologijo in občudovali glinaste posode, ki jih ni ustvarjal le za vsakdanjo uporabo, marveč tudi »za lépotu« in tudi za obisk sv. Janeza Pavla II., ki je konec 70-ih let obiskal Slovenijo ...

Koliko takšnih utrinkov! Iz dneva v dan so krasili Tvoje življenje in bogatili nas, ki smo Te srečevali. Vedno zavzeto za stvar, izvirno, s Tebi lastno neposrednostjo, človeško toplino in originalnostjo. Vse to je ostalo živo, čeprav morda ni nikjer zapisano. Hvala Ti, ker si bila med nami in z nami.

Martina Orožen 


\title{
Peter Grzybek
}

\author{
(November 22, 1957 - May 29, 2019)
}

\section{IN MEMORIAM}

International paremiology has lost one of its stellar scholars who had a tremendous influence on the multifaceted study of proverbs. In fact, were it not for Peter Grzybek, proverb scholarship would not have made the impressive theoretical progress that has taken place during the merely thirty-five years that he has tilled this rich field. Unfortunately and sadly he did not reach the old age that some of the other famous paremiologists like Archer Taylor (1890-1973), Bartlett Jere Whiting (1904-1995), Démétrios Loukatos (1908-2003), Matti Kuusi (1914-1998), Lutz Röhrich (1922-2006), Arvo Krikmann (1939-2017), and others obtained. Instead his life ended prematurely at the age of not even sixty-two years after having suffered with various illnesses that necessitated prolonged stays in hospitals. This parallels to a certain degree the life of his mentor and friend Grigorii L'vovich Permiakov (1919-1983) who died after a long illness at Moscow at only sixty-four years of age. Like Permiakov, Peter Grzybek was taken from us way too early, and the scholarly world of such disciplines as cultural studies, folklore, linguistics, literature, paremiology, phraseology, semantics, and semiotics mourn this incredibly productive colleague and friend whose intellectual prowess is evident in his complex publications and which could be observed during discussions at various international conferences. The written and spoken word of Peter Grzybek made people think outside the box resulting in new insights and unexpected discoveries.

Peter was born in the small city of Herne close to Bochum in North RhineWestphalia, Germany. From 1978-1984, he studied Slavic Philology, English, and Language Pedagogy at the Ruhr-Universität Bochum with various stays in the former Yugoslavia, Ukraine, the United States, and the Soviet Union. All of this made him a true polyglot person that can be seen in all of his publications. He finished his M. A. Thesis in 1984 with distinction and was able to publish it as Lechts und Rinks kann man nicht velwechsern?!? Zur Neurosemiotik sprachlicher Kommunikation (Trier: Linguistic Agency, University of Trier, 1984). Staying at Bochum, he worked at the Institute of Slavic Studies, continued his studies in 1986/87 at Moscow and Leningrad, and finished his dissertation in 1988 that appeared as a book one year later with which he made Russian scholarship accessible to semioticians everywhere: Studien zum Zeichenbegriff der sowjetischen Semiotik (Moskauer und Tartuer Schule) (Bochum: Norbert Brockmeyer, 1989). In 1992 he secured a position at the Institute of Slavic Studies at the Karl-Franzens-Universität Graz in Austria. Continuing his interest in semiotics and broadening his work to include folklore, he presented his cumulative "Habilitationsschrift" with the title 
Slawistische Studien zur Semiotik der Folklore at Graz that was based on some of his important work during the decade from 1984 to 1994. It was his good fortune to remain permanently employed as a professor at the Universität Graz to the end of his life, with guest professorships at the Universität Wien (1993/94) and the Humboldt-Universität Berlin (1999) as well as teaching assignments at the Universität Salzburg (2000/01) and the Kyrill-und-Method-Universität in Trnava, Slovakia (2001/04). He also was the head of the Institute of Slavic Studies at Graz between 2004 and 2011. Throughout his career, he proved himself to be a demanding, engaging, and inspiring instructor who cared deeply for his students and helped them as a mentor to succeed with their studies.

Peter Grzybek's scholarly work can be divided into three main parts. There is first of all his expertise in semiotics. In fact, from 1989 to 1997 he was one of the editors of Znakolog. An International Yearbook of Slavic Semiotics, and from 1985 to 1999 he was on the editorial board of Bochumer Beiträge zur Semiotik. In addition to his own semiotic articles he also edited several books, among them Cultural Semiotics - Facts and Facets / Fakten und Facetten der Kultursemiotik (Bochum: Norbert Brockmeyer, 1991), Psychosemiotik - Neurosemiotik / Psychosemiotics - Neurosemiotics (Bochum: Norbert Brockmeyer, 1993), and Synergetic Linguistics. Text and Language as Dynamic Systems (Wien: Praesens, 2012, with Sven Naumann, Relja Vulanović, and Gabriel Altmann). There is no doubt that Peter had a lasting influence on semiotics with a special comparative emphasis on culture, folklore, and language.

The second area of Peter's expertise is quantitative linguistics and literature. He was an active member of the International Quantitative Linguistics Association for many years and served as its vice president from 2009 to 2012. He was one of the editors of the book series Quantitative Linguistics and he also was an active member of the editorial boards of the journals Glottometrics (2004-) and Glottotheory (2008-). Many of his own articles are informed by detailed mathematical analyses of word and sentence lengths, and he also edited several volumes in this fascinating approach to language and literature, among them Contributions to the Science of Text and Language. Word Length Studies and Related Issues (Dordrecht: Springer, 2006), Exact Methods in the Study of Language and Text (Berlin/New York: Mouton de Gruyter, 2007, with Reinhard Köhler), and Text and Language. Structures, Functions, Interrelations. Quantitative Perspectives (Wien: Praesens, 2010, with Kelih Emmerich and Ján Mačutek).

It is, of course, the third area of Peter Grzybek's scholarly work that is of immense significance to paremiologists and phraseologists throughout the world. Since this obituary is addressing primarily scholars and students occupied with proverbial matters, the following comments will go into considerable more detail. He was one of the founders of the Westfälischer Arbeitskreis Phraseologie/ Parömiologie (1991-2002), a founding member of the European Society of Phraseology (1999-) and board member between 1999-2006, and a board member of the International Association of Paremiology at Tavira, Portugal (2007-). At the international meetings of these organizations Peter's voice could be heard as he argued for equitable rules and regulations, presented innovative ideas, and at times was more than willing to engage in rhetorical polemics. To be sure, his enthusiastic, 
engaged, and at times a bit aggressive comments and arguments were always meant in a constructive way with a bit of good humor mixed in as well. His heart was definitely in the right place, and at the bottom of his involvement was always the idea of fostering a meaningful scholarly exchange. This (com)passionate approach to scholarship was always also evident in his work as one of the editors (with Wolfgang Eismann and Wolfgang Mieder) of the two book series Studien zur Phraseologie und Parömiologie (1994-1998) and Phraseologie und Parömiologie (1998-). The books that have appeared in these series are clearly the better due to Peter's careful editorial work. His editorial commitment can also be seen from his work on such volumes as Sprachbilder zwischen Theorie und Praxis. Akten des Westfälischen Arbeitskreises Phraseologie/Parömiologie (1991/1992) (Bochum: Norbert Brockmeyer, 1994, with Christoph Chlosta and Elisabeth Piirainen), Kritik und Phrase. Festschrift für Wolfgang Eismann zum 65. Geburtstag (Wien: Praesens Verlag, 2007, with Peter Deutschmann, Ludvik Karničar, and Heinrich Pfandl), and Phraseologie im Wörterbuch und Korpus / Phraseology in Dictionaries and Corpora (Maribor: Zora, 2014, with Vida Jesenšek). This is also true of his role as a member of the editorial board of Proverbium. Yearbook of International Proverb Scholarship (2004-). I still remember how glad I was that he joined me in my efforts as the editor of this publication that I started in 1984. Of course, I regret that I did not ask my dear friend Peter to join the editorial board much earlier.

This reminds me that he was a most welcome contributor to the first volume of this publication with his short article on Grigorij L'vovich Permjakov [Permiakov] (1919-1983), Proverbium 1 (1984), 175-182. This was the beginning of our friendship that lasted for thirty-five years with a rich correspondence and the delight of meeting at international paremiological and phraseological conferences from time to time. But this paper on the greatest Russian paremiologists of the previous generation also marks the start of Peter Grzybek's sincere commitment to paremiological matters. Knowing that we all stand on the shoulders of those scholarly giants who influence us, Peter took it upon himself as a Slavist with an expertise in the Russian language to make Permiakov's theoretical work accessible worldwide (for an annotated bibliography of Permiakov's pioneering paremiological publications see Wolfgang Mieder, International Proverb Scholarship. An Annotated Bibliography. New York: Garland Publishing, 1982, pp. 339-343; II [1990], pp. 235-236; III [1993], pp. 551-559). Permiakov's groundbreaking scholarship that combined semantic, semiotic, and structural approaches with folkloric aspects in turn had a lasting influence on Peter Grzybek, as can be seen from his very first book that he edited together with our mutual friend Wolfgang Eismann from the Universität Graz: Semiotische Studien zum Sprichwort. Simple Forms Reconsidered I (Tübingen: Gunter Narr, 1984). The book includes articles by Peter on the semiotic approach to proverbs and the paremiological minimum that continued to occupy him in numerous publications during the years to come. Following Permiakov's insistence that proverbs are part of the so-called folkloric simple forms (fables, fairy tales, legends, riddles, jokes, etc.), he immersed himself into folk narrative scholarship and again together with Wolfgang Eismann edited a related second volume with the title Semiotische Studien zum Rätsel. Simple 
Forms Reconsidered II (Bochum: Norbert Brockmeyer, 1987) that includes several contributions by himself as well.

Several decades earlier the German scholar André Jolles had published his influential book Einfache Formen (Halle: Max Niemeyer, 1930; rpt. Tübingen: Max Niemeyer, 1958 and 1965) that has finally been translated into English by Peter J. Schwartz as Simple Forms (New York: Verso, 2017). The renowned German folklorist Hermann Bausinger took the matter up again with his book on Formen der "Volkspoesie" (Berlin: Erich Schmidt, 1968, 2nd ed. 1980), but what unfortunately is little known is that Walter A. Koch, one of Gryzbek's professors at the Universität Bochum, edited a seminal volume about twenty-five years later with the title Simple Forms. An Encyclopaedia of Simple Text-Types in Lore and Literature (Bochum: Norbert Brockmeyer, 1994). It will surprise no one that he solicited the help of his former star-student who contributed superb articles on the "Märchen" (pp. 144-157) and the "Riddle" (pp. 242-254). I don't know why this book has remained so unknown, but I recall the excitement of my famous folkloric and paremiological friend Alan Dundes (1934-2005) when I drew his attention to it. But be that as it may, Peter Grzybek also contributed absolutely enlightening entries on "Adage" (p. 1), "Apoththegm" (pp. 13-14), "Blason Populaire" (pp. 19-25), "[Proverbial] Comparison" (pp. 68-74), "Proverb” pp. 227-241), "Wellerism" (pp. 286-292), and "Winged Word" (pp. 293-298). Anybody who has written encyclopedia articles knows how challenging such entries are to compose, but Peter accomplished his task in typical magisterial fashion with his treatment of the proverb being of special value.

At this point it would be tempting to review each and every one of the paremiological articles listed in the hopefully complete bibliography below (all items are in my International Proverb Archives here at the University of Vermont). That is, of course, not possible and also not necessary, since many of them will be known as seminal contributions to paremiologists. I do, however, want to single out yet another edited book by Peter Grzybek, namely Die Grammatik der sprichwörtlichen Weisheit von G. L. Permjakov. Mit einer Analyse allgemein bekannter deutscher Sprichwörter (Baltmannsweiler: Schneider Verlag Hohengehren, 2000). The book represents another attempt to get the work of Permiakov better known among those not able to read his Russian publications. It contains five of Permiakov's articles translated by Peter as well as a detailed analysis of their significance. But at the end there is also a major contribution by Peter and his long-time friend Christoph Chlosta about the logico-semiotic classification of well-known German proverbs along Permiakov's model. It should be pointed out here, as is indicated in the attached bibliography, that Peter Grzybek obviously enjoyed working together with good colleagues and friends, notably Rupprecht S. Baur, Christoph Chlosta, Wolfgang Eismann, Rüdiger Grotjahn, Anna Tóthné Litovkina, and Undine Roos. We had started to discuss the possibility of working on a joint project, but this is now no longer feasible. I am certain that we would have enjoyed working together.

Peter Grzybek's articles written in German have definitely had and will continue to have great influence on German paremiology. If I had to single out a few of Peter Grzybek's most influential paremiological articles worldwide (written in English), I would pick the following: Foundations of Semiotic Proverb Study, Proverbium 4 
(1987), 39-85; also in Wise Words: Essays on the Proverb, ed. Wolfgang Mieder (New York: Garland Publishing, 1994), 31-71; and also slightly revised in De Proverbio. An Electronic Journal of International Paremiology 1/1 (1995), 206-229; Empirical and Folkloristic Paremiology: Two to Quarrel or to Tango? Proverbium 12 (1995), 67-85 (with Christoph Chlosta); and Semiotic and Semantic Aspects of the Proverb, Introduction to Paremiology. A Comprehensive Guide to Proverb Studies, eds. Hrisztalina Hrisztova-Gotthardt and Melita Aleksa Varga (Berlin: Walter de Gruyter, 2015), 68-111. But be that as it may, here is a list of key terms that indicate Peter Grzybek's multifaceted comparative and polyglot approach to proverb studies: comparison, computation, culture, empiricism, experiment, familiarity, folklore, frequency, genre, knowledge, length, lexicography, linguistics, literature, mass media, mathematics, meteorology, obsoleteness, paremiological minimum, popularity, semantics, semiotics, simple forms, statistics, stereotype, structure, variant, and variation. With such scholarly breadth and width, how could Peter Grzybek's scholarly accomplishments not continue to influence future paremiology!

But how does one say good-bye to such an internationally renowned scholar and dear friend? As I have gotten older, I have so very much become aware what losing such compatriots as the above-mentioned deceased friends means. And now Peter is gone as well, leaving a void, sadness, and a feeling of loneliness. Should we despair? That would not be in Peter's spirit. I am certain that he would want us to carry the torch of paremiology forward by honoring his work and by keeping his memory in our minds and hearts. Farewell, Peter Grzybek, you did your work well - "Finis coronat opus."

\section{PETER GRZYBEK'S PAREMIOLOGICAL PUBLICATIONS}

\section{4}

(Ed.). Semiotische Studien zum Sprichwort. Simple Forms Reconsidered I. Tübingen: Gunter Narr, 1984. 259 pp. (= Kodikas Code - Ars Semeiotica: An International Journal of Semiotics 7/3-4 (1984), 197-456). With Wolfgang Eismann.

Bibliographie der Arbeiten G. L. Permjakovs. Semiotische Studien zum Sprichwort. Simple Forms Reconsidered I. Eds. P. Grzybek and W. Eismann. Tübingen: Gunter Narr, 1984. 203-214.

Grigorij L'vovich Permjakov (1919-1983). Semiotische Studien zum Sprichwort. Simple Forms Reconsidered I. Eds. P. Grzybek and W. Eismann. Tübingen: Gunter Narr, 1984. 199-201.

Grigorij L'vovich Permjakov (1919-1983). Proverbium 1 (1984), 175-182.

How to Do Things with Some Proverbs: Zur Frage eines parömischen Minimums. Semiotische Studien zum Sprichwort. Simple Forms Reconsidered I. Eds. P. Grzybek and W. Eismann. Tübingen: Gunter Narr, 1984. 351-358.

Überlegungen zur semiotischen Sprichwortforschung. Semiotische Studien zum Sprichwort. Simple Forms Reconsidered I. Eds. P. Grzybek and W. Eismann. Tübingen: Gunter Narr, 1984. 215-249. 
Zur lexikographischen Erfassung von Sprichwörtern. Semiotische Studien zum Sprichwort. Simple Forms Reconsidered I. Eds. P. Grzybek and W. Eismann. Tübingen: Gunter Narr, 1984. 345-350.

Zur Psychosemiotik des Sprichworts. Semiotische Studien zum Sprichwort. Simple Forms Reconsidered I. Eds. P. Grzybek and W. Eismann. Tübingen: Gunter Narr, 1984. 409-432.

1985

G. L. Permyakov 1919-1983. Scottish Slavonic Review 5 (1985), 170-171.

Review of Paremiologicheskie issledovaniya. Sbornik statei. Sostavlenie i redaksiya G. L. Permyakova. Predislovie Y. V. Civ'yan. Moskva: Nauka, 1984. Proverbium 2 (1985), 339-351.

1986

Review of Neal R. Norrick. How Proverbs Mean. Semantic Studies in English Proverbs. Amsterdam: Mouton, 1985. Proverbium 3 (1986), 373-380.

Review of G. L. Permjakov. 300 allgemeingebräuchliche russische Sprichwörter und sprichwörtliche Redensarten. Ein illustriertes Nachschlagewerk für Deutschsprechende. Moskva: Russkij jazyk, 1985. Leipzig: VEB Verlag Enzyklopädie, 1985. Zielsprache Russisch 7/2 (1986), 61-63.

Zur Entwicklung semiotischer Sprichwortforschung in der UdSSR. Geschichte und Geschichtsschreibung der Semiotik - Fallstudien. Eds. Klaus D. Dutz and Peter Schmitter. Münster: Münsteraner Arbeitskreis für Semiotik Publikationen, 1986. 383-409.

\section{7}

Foundations of Semiotic Proverb Study. Proverbium 4 (1987), 39-85. (Also in: Wise Words: Essays on the Proverb. Ed. Wolfgang Mieder. New York: Garland Publishing, 1994. 31-71; also slightly revised in: De Proverbio. An Electronic Journal of International Paremiology 1/1 (1995), 206-229.)

\section{8}

Sprichwort und Fabel: Überlegungen zur Beschreibung von Sinnstrukturen in Texten. Proverbium 5 (1988), 39-67.

1989

Invariant Meaning Structures in Texts: Proverb and Fable. Issues in Slavic Literary and Cultural Theory. Eds. K. Eimermacher, P. Grzybek, and G. Witte. Bochum: Norbert Brockmeyer, 1989. 349-389.

Review of Elza Kokare. Lettische und deutsche Sprichwortparallelen. Riga: Zinatne, 1988. Fabula 30 (1989), 331-333.

Two Recent Publications in Soviet Structural Paremiology. Proverbium 6 (1989), 181-186.

1990

Kulturelle Stereotype und stereotype Texte. Natürlichkeit der Sprache und Kultur. Ed. Walter A. Koch. Bochum: Norbert Brockmeyer, 1990. 300-327.

Review of Heinz Rölleke (ed.) Redensarten des Volks, auf die ich immer horche. Das Sprichwort in den Kinder- und Hausmärchen Brüder Grimm. Bern: Peter Lang, 1988. Fabula 31 (1990), 174-175. 
Untersuchungen zu einem parömischen Minimum im Deutschen. Interkulturelle Kommunikation. Kongreßbeiträge zur 20. Jahrestagung der Gesellschaft für Angewandte Linguistik. Ed. Bernd Spillner. Bern: Peter Lang, 1990. 220-223. With Rupprecht S. Baur.

1991

Das Sprichwort im literarischen Text. Sprichwörter und Redensarten im interkulturellen Vergleich. Eds. Annette Sabban and Jan Wirrer. Opladen: Westdeutscher Verlag, 1991. 187-205.

Einfache Formen der Literatur als Paradigma der Kultursemiotik. Cultural Semiotics: Facts and Facets / Fakten und Facetten der Kultursemiotik. Ed. Peter Grzybek. Bochum: Norbert Brockmeyer, 1991. 45-61 (esp. pp. 52-58).

Sinkendes Kulturgut? Eine empirische Pilotstudie zur Bekanntheit deutscher Sprichwörter. Wirkendes Wort 41/2 (1991), 239-264.

Zur semantischen Funktion der sprichwörtlichen Wendungen in Božena Nemcovás Babichka. Zur Poetik und Rezeption von Božena Nemcovás "Babichka". Ed. Andreas Guski. Wiesbaden: Otto Harrassowitz, 1991. 81-126.

\section{2}

Probleme der Sprichwort-Lexikographie (Parömiographie): Definition, Klassifikation, Selektion. Worte, Wörter, Wörterbücher. Lexikographische Beiträge zum Essener Linguistischen Kolloquium. Eds. Gregor Meder and Andreas Dörner. Tübingen: Max Niemeyer, 1992. 195-223.

\section{3}

Das Sprichwort in der überregionalen Tagespresse: Eine systematische Analyse zum Vorkommen von Sprichwörtern in den Tageszeitungen Die Welt, Frankfurter Allgemeine Zeitung und Süddeutsche Zeitung. Wirkendes Wort 43/3 (1993), 671-695. With Christoph Chlosta, Zorica Stankovic-Arnold, and Andreas Steczka.

Der Weisheit der Gasse auf der Spur: Eine empirische Pilotstudie zur Bekanntheit kroatischer Sprichwörter. Zeitschrift für Balkanologie 29/2 (1993), 85-98. With Danica Škara and Zdenka Heyken.

Grundlagen der empirischen Sprichwortforschung. Proverbium 10 (1993), 89-128. With Christoph Chlosta.

Statistical Methods in the Study of Proverb Knowledge: An Analysis of the Knowledge of Proverbs in Contemporary Hungarian Culture (Tolna County). Semiotische Berichte 17/3-4 (1993), 275-308. With Rüdiger Grotjahn, Anna Tóthné Litovkina, Christoph Chlosta, and Undine Roos.

\section{4}

Adage. Simple Forms: An Encyclopedia of Simple Text-Types in Lore and Literature. Ed. Walter A. Koch. Bochum: Norbert Brockmeyer, 1994. 1.

Apophthegm [Apothegm]. Simple Forms: An Encyclopedia of Simple Text-Types in Lore and Literature. Ed. Walter A. Koch. Bochum: Norbert Brockmeyer, 1994. 13-14.

Blason Populaire. Simple Forms: An Encyclopedia of Simple Text-Types in Lore and Literature. Ed. Walter A. Koch. Bochum: Norbert Brockmeyer, 1994. 19-25.

Comparison. Simple Forms: An Encyclopedia of Simple Text-Types in Lore and Literature. Ed. Walter A. Koch. Bochum: Norbert Brockmeyer, 1994. 68-74. 
Ein Vorschlag zur Klassifikation von Sprichwortvarianten bei der empirischen Sprichwortforschung. Europhras 92: Tendenzen der Phraseologieforschung. Ed. Barbara Sandig. Bochum: Norbert Brockmeyer, 1994. 221-256. With Christoph Chlosta and Undine Roos.

Empiricheskaia semiotika kul'tury na primere issledovaniia poslovits $\mathrm{s}$ ispol'zovaniem rezul'tatov probnogo opytnogo izucheniia izvestnosti khorvatskikh poslovits. Znaki Balkan 2 (1994), 312-338.

Perspektiven einer empirischen Parömiologie (Sprichwortforschung). Zeitschrift für Empirische Textforschung 1 (1994), 94-98. With Rupprecht S. Baur and Christoph Chlosta.

Proverb. Simple Forms: An Encyclopedia of Simple Text-Types in Lore and Literature. Ed. Walter A. Koch. Bochum: Norbert Brockmeyer, 1994. 227-241.

(Eds.). Sprachbilder zwischen Theorie und Praxis. Akten des Westfälischen Arbeitskreises Phraseologie / Parömiologie (1991/1992). Bochum: Norbert Brockmeyer, 1994. 305 pp. With Christoph Chlosta and Elisabeth Piirainen.

Sprichwort, sprichwörtliche Redensart und Phraseologismus: Vom Mythos der NichtTrennbarkeit. Sprachbilder zwischen Theorie und Praxis. Eds. Christoph Chlosta, Peter Grzybek, and Elisabeth Piirainen. Bochum: Norbert Brockmeyer, 1994. 89-132. With Wolfgang Eismann.

Wellerism. Simple Forms: An Encyclopedia of Simple Text-Types in Lore and Literature. Ed. Walter A. Koch. Bochum: Norbert Brockmeyer, 1994. 286-292.

Wer kennt denn heute noch den Simrock? Ergebnisse einer empirischen Untersuchung zur Bekanntheit deutscher Sprichwörter in traditionellen Sammlungen. Sprachbilder zwischen Theorie und Praxis. Eds. Christoph Chlosta, Peter Grzybek, and Elisabeth Piirainen. Bochum: Norbert Brockmeyer, 1994. 31-60. With Christoph Chlosta und Undine Roos.

Winged Word. Simple Forms: An Encyclopedia of Simple Text-Types in Lore and Literature. Ed. Walter A. Koch. Bochum: Norbert Brockmeyer, 1994. 293-298.

\section{5}

Empirical and Folkloristic Paremiology: Two to Quarrel or to Tango? Proverbium 12 (1995), 67-85. With Christoph Chlosta.

Verbale und nonverbale Phraseologie. Niederdeutsches Wort 35 (1995), 3-29. With 12 illustrations. With Rupprecht S. Baur and Christoph Chlosta.

Zur Frage der Satzlänge von Sprichwörtern (unter besonderer Berücksichtigung deutscher Sprichwörter). Von der Einwortmetapher zur Satzmetapher. Eds. Rupprecht S. Baur and Christoph Chlosta. Bochum: Norbert Brockmeyer, 1995. 203-217.

\section{6}

Anmerkungen zu Obsoletheit und Bekanntheit traditioneller kroatischer Sprichwörter. II: Die Hrvatske narodne poslovice von Juraj Vicko Skarpa (1909). Suvremena lingvistika 22/1-2 (1996), 183-198.

Das Projekt 'Sprichwörter-Minima im Deutschen und Kroatischen': What is worth doing - do it well! Muttersprache 106 (1996), 162-179. With Rupprecht S. Baur and Christoph Chlosta.

\section{7}

Anmerkungen zu Obsoletheit und Bekanntheit traditioneller kroatischer Sprichwörter. I: Die Poslovice von Gjuro Daničić (1871). Prvi hrvatski slavistički kongres. Zbornik radova. Ed. Josip Bratulić and Stjepan Damjanović. Zagreb: Hrvatsko filološko društvo, 1997. 149-163. Published after II. 
Remarks on Obsoleteness and Familiarity with Traditional Croatian Proverbs. III: Mijat Stojanović's Sbirka narodnih poslovicah, riečih i izrazah (1866). Narodna umjetnost 34/1 (1997), 201-223.

Sprichwortkenntnis in Deutschland und Österreich: Empirische Ergebnisse zu einigen mehr oder weniger gewagten Hypothesen. Österreichisches Deutsch und andere nationale Varietäten plurizentrischer Sprachen in Europa. Eds. Rudolf Muhr and Richard Schrodt. Wien: Verlag Hölder-Pichler-Tempsky, 1997. 243-260. With Christoph Chlosta.

\section{8}

Explorative Untersuchungen zur Wort- und Satzlänge kroatischer Sprichwörter (Am Beispiel der Poslovice von Đuro Daničić [1871]). Politropon. K 70-letiiu Vladimira Nikolaevicha Toporova. Ed. T. M. Nikolaeva. Moskva: Izdatel'stvo Indrik, 1998. 447-465.

Komparative und interkulturelle Parömiologie: Methodologische Bemerkungen und empirische Befunde. Europhras 95: Europäische Phraseologie im Vergleich: Gemeinsames Erbe und kulturelle Vielfalt. Ed. Wolfgang Eismann. Bochum: Norbert Brockmeyer, 1998. 263-282.

Paroemiology [sic]. Encyclopedia of Semiotics. Ed. Paul Bouissac. New York: Oxford University Press, 1998. 470-474.

Prolegomena zur Bildhaftigkeit von Sprichwörtern. Im Zeichen-Raum: Festschrift für Karl Eimermacher. Eds. Anne Hartmann and Christoph Veldhues. Dortmund: Projekt Verlag, 1998. 133-152.

Sprichwort - Wahrwort? Die 'Weisheit auf der Gasse' zwischen Norm und Denkmodell. Kultur und Lebenswelt als Zeichenphänomene. Eds. Jeff Bernard and Gloria Withalm. Wien: ÖGS/ISSS, 1998. 127-148

1999

Empirische Befunde zur Theorie stereotyper Vergleiche. Bosnische Vergleiche auf dem Prüfstand. Wörter in Bildern - Bilder in Wörtern: Beiträge zur Phraseologie und Sprichwortforschung aus dem Westfälischen Arbeitskreis. Eds. Rupprecht S. Baur, Christoph Chlosta, and Elisabeth Piirainen. Baltmannsweiler: Schneider Verlag Hohengehren, 1999. 177-198.

South Slavic Erotic Folklore: Remarks on Traditional Erotic Phraseology from Dalmatia. Semiotische Berichte 23/1-4 (1999), 131-154. (Also in Serbian translation as: Južnoslovenski erotski folklor: Zapažanja o narodnoj erotskoj frazeologiji iz Dalmacije. Erotsko u folkloru Slovena. Zbornik radova. Ed. Dejan Ajdačić. Beograd: Stubovi kulture, 2000. 295-325.)

Wie lang sind slowenische Sprichwörter? Zur Häufigkeitsverteilung von (in Worten berechneten) Satzlängen slowenischer Sprichwörter. Anzeiger für Slavische Philologie 27 (1999), $87-108$.

\section{0}

(Ed.). Die Grammatik der sprichwörtlichen Weisheit von G. L. Permjakov. Mit einer Analyse allgemein bekannter deutscher Sprichwörter. Baltmannsweiler: Schneider Verlag Hohengehren, 2000. 199 pp.

Methodological Remarks on Statistical Analyses in Empirical Paremiology. Proverbium 17 (2000), 121-132. With Rüdiger Grotjahn.

Review of Peter Ďurčo. Europhras 97. Phraseology and Paremiology. Bratislava: Akadémia PZ, 1998. Anzeiger für Slavische Philologie 27 (2000), 219-222. 
Versuch macht klug! Logisch-semiotische Klassifikation allgemein bekannter Sprichwörter. Die Grammatik der sprichwörtlichen Weisheit von G. L. Permjakov. Mit einer Analyse allgemein bekannter deutscher Sprichwörter. Ed. Peter Grzybek. Baltmannsweiler: Schneider Verlag Hohengehren, 2000. 169-199. With Christoph Chlosta.

Zum Status der Untersuchung von Satzlängen in der Sprichwortforschung: Methodologische Vor-Bemerkungen. Slovo vo vremeni i prostranstve. K 60-letiiu professora V. M. Mokienko. Eds. G. A. Lilich, A. K. Birikh, and E. K. Nikolaeva. Sankt-Peterburg: Folio-Press, 2000. 430-457.

\section{1}

Zur Satz- und Teilsatzlänge formelhafter zweigliedriger Sprichwörter. Text as a Linguistic Paradigm: Levels, Constituents, Constructs. Festschrift für Luděk Hřebiček. Eds. Ludmila Uhlírová, Gejza Wimmer, Gabriel Altmann, and Reinhard Köhler. Trier: Wissenschaftlicher Verlag Trier, 2001. 64-75.

2002

Zur Satzlänge deutscher Sprichwörter. Ein Neuansatz. Phraseologie in Raum und Zeit: Akten der 10. Tagung des Westfälischen Arbeitskreises Phraseologie/Parömiologie (Münster 2001). Eds. Elisabeth and Ilpo Tapani Piirainen. Baltmannsweiler: Schneider Verlag Hohengehren, 2002. 287-305. With Rudolf Schlatte.

\section{3}

Zur lexikalischen Struktur von Sprichwörtern. Flut von Texten - Vielfalt der Kulturen: Ascona 2001 zur Methodologie und Kulturspezifik der Phraseologie. Eds. Harald Burger, Annelies Häcki Buhofer, and Gertrud Gréciano. Baltmannsweiler: Schneider Verlag Hohengehren, 2003. 97-116. (Also in English: A Quantitative Approach to Lexical Structure of Proverbs. Journal of Quantitative Linguistics 11/1-2 (2004), 79-92.)

\section{4}

Was heißt eigentlich 'Bekanntheit' von Sprichwörtern? Methodologische Bemerkungen anhand einer Fallstudie zur Bekanntheit anglo-amerikanischer Sprichwörter in Kanada und in den USA. Res humanae proverbiorum et sententiarum. Ad honorem Wolfgangi Mieder. Ed. Csaba Földes. Tübingen: Gunter Narr, 2004. 37-57. With Christoph Chlosta.

Worthäufigkeit und Wortlänge in Sprichwörtern (am Beispiel slowenischer Sprichwörter). Phraseologismen als Gegenstand sprach- und kulturwissenschaftlicher Forschung. Akten der Europäischen Gesellschaft für Phraseologie (Europhras) und des Westfälischen Arbeitskreises Phraseologie/Parömiologie (Loccum 2002). Eds. Csaba Földes and Jan Wirrer. Baltmannsweiler: Schneider Verlag Hohengehren, 2004. 47-58.

Zur Wortlänge und ihrer Häufigkeitsverteilung in Sprichwörtern (am Beispiel slowenischer Sprichwörter, mit einer Re-Analyse estnischer Sprichwörter). Europhras 2000. Internationale Tagung zur Phraseologie vom 15.-18. Juni 2000 in Aske / Schweden. Ed. Christine Palm Meister. Tübingen: Stauffenburg, 2004. 161-171.

\section{5}

Varianten anglo-amerikanischer Sprichwörter: Dokumentation einer empirischen Untersuchung. Essener Linguistische Skripte_elektronisch 5/2 (2005), 63-145.

2007

(Ed.). Kritik und Phrase. Festschrift für Wolfgang Eismann zum 65. Geburtstag. Wien: Praesens Verlag, 2007. 832 pp. With Peter Deutschmann, Ludvik Karničar, and Heinrich Pfandl. 
Semiotik und Phraseologie. Phraseologie. Ein internationales Handbuch zeitgenössischer Forschung. Eds. Harald Burger, Dmitrij Dobrovol'skij, Peter Kühn, and Neal R. Norrick. Berlin: Walter de Gruyter, 2007. I, 188-208.

\section{8}

Fundamentals of Slovenian Paremiology. Traditiones 37/1 (2008), 23-46.

2009

Poslovitsa i ee situatsii: ot opredeleniia k klassifikatsii. Zhivaia Starina 4 (2009), 51-54.

Some Essentials on the Popularity of (American) Proverbs. The Proverbial "Pied Piper". A Festschrift Volume of Essays in Honor of Wolfgang Mieder on the Occasion of His Sixty-Fifth Birthday. Ed. Kevin J. McKenna. New York: Peter Lang, 2009. 95-110. With Christoph Chlosta.

The Popularity of Proverbs. A Case Study of the Frequency-Familiarity Relation for German. Proceedings of the Second Interdisciplinary Colloquium on Proverbs, 9th to 16th November 2008, at Tavira, Portugal. Eds. Rui J. B. Soares and Outi Lauhakangas. Tavira: Tipografia Tavirense, 2009. 214-229. With 7 diagrams.

\section{0}

Überlegungen zur empirischen Validierung von Sprichwörter-Dummies. Sprachlehrforschung: Theorie und Empirie. Festschrift für Rüdiger Grotjahn. Eds. Annette Berndt and Karin Kleppin. Frankfurt am Main: Peter Lang, 2010. 197-209. With Christoph Chlosta.

\section{2}

Facetten des parömiologischen Rubik-Würfels. Kenntnis $\equiv$ Bekanntheit [ $\leftrightarrow$ Verwendung $\approx$ Frequenz]?!? Sprichwörter multilingual. Theoretische empirische und angewandte Aspekte der modernen Parömiologie. Ed. Kathrin Steyer. Tübingen: Narr Verlag, 2012. 99-138.

Proverb Variants and Variations: A New Problem? Proceedings of the Fifth Interdisciplinary Colloquium on Proverbs, 6th to 13th November 2011, at Tavira, Portugal. Eds. Rui J. B. Soares and Outi Lauhakangas. Tavira: Tipografia Tavirense, 2012. 135-152.

\section{4}

In Honorem: Grigorij L'vovič Permjakov (1919-1983). A Biographical Mini-Sketch. 8th Interdisciplinary Colloquium on Proverbs, 2nd to 9th November 2014, at Tavira, Portugal [Program]. Eds. Rui J. B. Soares and Outi Lauhakangas. Tavira: Tipografia Tavirense, 2014. 107-109. With 1 picture.

Mosaic or Jigsaw? Publishing an Article from Estonia in the 'West', 30 Years Ago, When Circumstances Were Quite Different from Today. Proverbium 31 (2014), 11-34.

(Ed.) Phraseologie im Wörterbuch und Korpus/Phraseology in Dictionaries and Corpora. Maribor: Univerza v Mariboru, 2014. 287 pp. With Vida Jesenšek.

Regularities of Estonian Proverb Word Length: Frequencies, Sequences, Dependencies. Scala naturae. Festschrift in Honor of Arvo Krikmann for His $75^{\text {th }}$ Birthday. Eds. Anneli Baran, Liisi Laineste, and Piret Vooliad. Tartu: Estonian Literary Museum Scholarly Press, 2014. 121-148.

Simple Forms. Encyclopedia of Humor Studies. Ed. Salvatore Attardo. Los Angeles: Sage, 2014. II, 693-695. 


\section{5}

Semiotic and Semantic Aspects of the Proverb. Introduction to Paremiology. A Comprehensive Guide to Proverb Studies. Eds. Hrisztalina Hrisztova-Gotthardt and Melita Aleksa Varga. Berlin: Walter de Gruyter, 2015. 68-111.

Chlosta, Christoph, and Peter Grzybek. Zum Teufel mit dem ...: Anfang und Ende in der experimentellen Parömiologie. "Bis dat, qui cito dat". "Gegengabe" in Paremiology, Folklore, Language, and Literature. Honoring Wolfgang Mieder on His Seventieth Birthday. Eds. Christian Grandl and Kevin J. McKenna. Frankfurt am Main: Peter Lang, 2015. 109-120. With Christoph Chlosta.

\section{6}

On Whether Weather Proverbs Are Weather Proverbs. Towards a Fresh Look at Weather Lore and Meteo-Prognostic Paroemias. Proceedings of the Ninth Interdisciplinary Colloquium on Proverbs, 1st to 8th November 2015, at Tavira, Portugal. Eds. Rui J. B. Soares and Outi Lauhakangas. Tavira: Tipografia Tavirense, 2016. 273-290. With 1 illustration.

\section{Wolfgang Mieder}

Department of German and Russian, University of Vermont, Burlington,Vermont 05405,USA,Wolfgang.Mieder@uvm.edu 


\section{IVAN CANKAR V MEDKULTUR- NEM PROSTORU. OB STOTI OBLETNICI CANKARJEVE}

SMRTI. Maribor: Univerzitetna založba Univerze, 2018 (Mednarodna knjižna zbirka Zora, 126). 430 str.

\section{Znanstvena monografija Ivan Cankar} $v$ medkulturnem prostoru je nastala $\mathrm{v}$ Cankarjevem letu 2018 ob stoti obletnici pisateljeve smrti. Uredile so jo dr. Jožica Čeh Steger, dr. Simona Pulko in dr. Melita Zemljak Jontes z Oddelka za slovanske jezike in književnosti Filozofske fakultete Univerze v Mariboru. Naslovnico knjige krasi slika elegantno oblečenega Ivana Cankarja z meščanskim klobukom na glavi (Plakat s portretom Ivana Cankarja, Tiskarna Ljudske pravice, 1946, vir: UKM, Zbirka drobnih tiskov), na zavihkih platnic pa je v slovenskem, nemškem, češkem in madžarskem jeziku zapisan odlomek iz Cankarjevega Hlapca Jerneja in njegove pravice, ki pripoveduje o Jernejevem doživetju večkulturne cesarske prestolnice:

\footnotetext{
Neskončno mesto, do nebes bučeče, $v$ vseh nerazumljivih jezikih govoreče - sam strašni Babilon! Kam bi se skril človek, kam bi pobegnil? Jernej je taval po široki cesti: gradovi na obeh straneh, vozovi vsenavzkriž, gneča tujih, mrkogledih ljudi je hitela ter se prerivala kraj ceste, kakor da bi se bilo srečalo in zagozdilo dvoje večnih procesij. Koga bi vprašal, kako bi vprašal? $\mathrm{S}$ klobukom $\mathrm{v}$ roki je taval med njimi in sam čutil, da je zablodil mednje, kakor da je bil zablodil golorok in bosonog ob peti maši pred veliki oltar. (Cankar 1972: 63)
}

Monografija ima Uvodno besedo, v kateri Jožica Čeh Steger povzame vsebino posameznih razprav in umesti knjigo v kontekst kulturnih ter znanstvenih dogodkov v Cankarjevem letu, tri obsežna poglavja (Meddisciplinarne, literarnozgodovinske, kulturološke in prevodoslovne raziskave, Jezikoslovne razprave Cankarjevih literarnih del, Cankar v šoli), povzetek v slovenskem in angleškem jeziku ter tri recenzije, ki so jih napisali red. prof. dr. Janez Vrečko, red. prof. dr. Andreja Žele in izr. prof. dr. Tamara Turza - Bogdan.

Monografija Ivan Cankar v medkulturnem prostoru vsebuje sedemintrideset razprav raziskovalcev in raziskovalk iz Slovenije, Avstrije, Italije, Slovaške, Nemčije in Rusije, ki umeščajo velikana slovenske in evropske književnosti $\mathrm{v}$ medkulturni prostor, ga aktualizirajo in na novo ovrednotijo $\mathrm{z}$ meddisciplinarnega, literarnozgodovinskega, kulturološkega, prevodoslovnega, jezikoslovnega in didaktičnega vidika.

Poglavje Meddisciplinarne, LITERARNOZGODOVINSKE, KULTUROLOŠKE IN PREVODOSLOVNE RAZISKAVE je razdeljeno v štiri zaokrožene sklope: Cankar in različni diskurzi, Cankar, večjezičnost, medkulturnost in prevodi njegovih del, Cankar in njegovi literarni sodobniki ter Recepcijske, interpretacijske, medbesedilne in medmedialne raziskave Cankarjevih del.

V sklopu CANKAR IN RAZLIČNI DISKURZI so zajete razprave, ki povezujejo Cankarja in njegovo ustvarjalnost $\mathrm{s}$ politiko, filozofijo, zgodovino in jezikovno politiko. To so razprave: Erwina Köstlerja (Literatura in politika pri Ivanu Cankarju), Božidarja Kanteta (Vpliv Ralpha Walda Emersona na Cankarja: transcendentalizem, subjektivnost in vesoljna duša), Aleša Mavra (Od Petra Klepca do nadučitelja Ferjana: Cankarjeva srečevanja s slovensko zgodovino) in Marka Jesenška (Cankar in slovenska jezikovna politika). E. Köstler se v svoji razpravi kritično opredeli do dualizma pri interpretaciji Cankarjeve besedne umetnosti na eni in publicistike na drugi strani. Zavzema se za lik Cankarja, ki 
je oblikoval zgodovinsko in politično resničnost kot umetnik, publicist in politični mislec, zato predlaga zavestno branje Cankarja v smislu obravnavanih politik v njegovih delih in celostno raziskavo politike ter literature $v$ njegovem opusu z vidika kulturoloških ved. B. Kante razmišlja o Cankarjevem branju Emersona in obratu v subjektivizem, alegorični simbol smrti v Cankarjevi črtici Gospod stotnik pa razlaga kot ikono smrti. A. Maver se ukvarja s Cankarjevim razumevanjem slovenske zgodovine $\mathrm{v}$ njegovi publicistiki in literaturi, pri čemer ugotavlja pisateljevo ujemanje S prevladujočimi stališči 20. stoletja V razumevanju Slovencev kot tlačenega naroda, reformacije in kmečkih uporov, največji odmik pa v poudarjanju kulturnih in jezikovnih razlik od južnoslovanskega sveta, zavračanju politične sloge in sklepanju kompromisov na račun individualnega svobodnega izražanja mnenj. M. Jesenšek razbira Cankarjevo razumevanje jezikovne politike v njegovih političnih člankih, govorih in predavanjih ter ugotavlja, da je bila pisateljeva misel o jeziku in kulturi zelo sodobna. Ko je Cankar zagovarjal slovensko jezikovno in kulturno samobitnost ter ostro zavračal pojave novoilirizma in jugoslovenarstva, se je obenem zavzemal za ohranjanje večkulturnosti in večjezičnosti, kar je tudi temelj jezikovne politike v Evropski zvezi (Čeh Steger 2018: 11-12).

V drugem sklopu CANKAR, VEČJEZIČNOST, MEDKULTURNOST IN PREVODI NJEGOVIH DEL so zbrane razprave o Cankarjevi večjezičnosti in medkulturnosti, o podobah tujega in tematizaciji pokrajine v Cankarjevih literarnih delih ter o odrskih uprizoritvah in prevodih Cankarjevih del v tuje jezike.

To so razprave: Jožice Čeh Steger (O Cankarjevi slovensko-nemški dvojezičnosti v kontekstu večkulturne Avstro-Ogrske), Irene Avsenik Nabergoj (Podobe Judov v Cankarjevih delih med stereotipi in umetniško ustvarjalnostjo), Alojzije Zupan Sosič (Podobe lastnega in tujega/drugega v treh Cankarjevih romanih), Vladke Tucovič (Istra v kratki prozi in pismih Ivana Cankarja), Francija Justa (Cankar v prekmurščini), Istvána Lukácsa (Arhaične proznopoetične simbolistične konstrukcije v času slovenske in madžarske moderne - Ivan Cankar in Béla Balázs), Jutke Rudaš (Hlapec Jernej in slovensko-madžarski medkulturni stiki), Gjoka Nikolovskega (Cankarjev Hlapec Jernej in njegova pravica $v$ makedonščini), Saše Vojtech Poklač in Miroslava Vojtecha (Dramatika Ivana Cankarja v slovaških prevodih in na odrskih deskah slovaških gledališč), Vesne Mikolič (Naklonjenost v Cankarjevem romanu Martin Kačur in njegovem italijanskem prevodu), Tomaža Oniča (Prevodni premiki v angleškem prevodu Cankarjevega Gospoda stotnika), Urše Marinšek in Tomaža Oniča (Recepcija uprizoritve Cankarjevega Pohujšanja v San Diegu).

J. Čeh Steger ugotavlja, da razlogi za Cankarjevo skoraj povsem enojezično (slovensko) literarno ustvarjanje na Dunaju, kjer je vstopal v hibridne kulturne prostore in jih tako tematiziral, niso bili povezani z njegovo jezikovno kompetenco $\mathrm{v}$ nemščini, temveč $\mathrm{z}$ visoko zavestjo ustvarjanja nacionalne literature in z zgodovinskimi okoliščinami notranjega kolonializma v Avstro-Ogrski. I. Avsenik Nabergoj razmišlja o Cankarjevem odnosu do Judov v kontekstu sekulariziranega antisemitizma in se osredini zlasti na opise Judov in Judinj $\mathrm{v}$ literarnih delih, nastalih $\mathrm{v}$ času pisateljevega bivanja na Dunaju. A. Zupan Sosič analizira podobe lastnega in tujega v romanih Tujci, Križ na gori in Gospa 
Judit $\mathrm{z}$ metodami ter orodji pripovedne empatije in ugotavlja povezanost teh podob $\mathrm{z}$ razmerji do domovine, tujine, naroda, umetnika in morale. V. Tucovič prikaže Cankarjevo dvojno percepcijo Istre, tj. navdušenje nad morjem in istrskim podeželjem $\mathrm{v}$ kratki prozi ter negativno podobo Pulja v ljubezenskih pismih, ki jih je leta 1898 od tam pošiljal Anici Lušin. F. Just predstavi prevode Cankarjeve kratke proze v prekmurščino v tedniku Novine med letoma 1928-1929, v času, ko je nova oblast na nekaterih področjih javnega življenja še dopuščala uporabo prekmurskega jezika. Lukács poišče vzporednice med Cankarjevim Kurentom in novelo Tišina njegovega madžarskega sodobnika Béle Balázsa. S primerjalno študijo pokaže, da je Cankar na Madžarskem zanimiv ne le zaradi socialnih, nacionalnih in matjaževskih tem, temveč tudi zaradi artističnega pripovednega diskurza, značilnega za srednjeevropske moderne, in ugotavlja, da so arhaične proznopoetične konstrukcije od moderne naprej pomemben del strukture žanrov 20. stoletja. J. Rudaš piše o pomenu Pavlovega prevoda Cankarjevega Hlapca Jerneja in njegove pravice, ki je tudi prvi knjižni prevod slovenske književnosti v madžarščini, za slovensko-madžarske kulturne stike. Osredinja se na analizo jezikovnih razlik in kulturnih posebnosti pri prevajanju tega Cankarjevega besedila v madžarščino. G. Nikolovski ugotavlja ob izbranih makedonskih prevodih Cankarjevega Hlapca Jerneja in njegove pravice najpogostejše strategije pri prevajanju kulturnospecifičnih prvin iz slovenščine $\mathrm{v}$ makedonščino. S. Vojtech Poklač in M. Vojtech se posvečata prevodom Cankarjevih dramskih besedil na Slovaškem in uprizoritvam njegove farse Pohujšanje v dolini šentflorjanski na odrih slovaških gledališč, posebej predstavi v Slovaškem narodnem gledališču v Bratislavi iz leta 1932 v režiji Andreja Bagarja, in na odrih slovaških amaterskih gledaliških skupin. V. Mikolič je z vidika literarne in medkulturne pragmatike analizirala izraze moči ali intenzitete jezika v Cankarjevem Martinu Kačurju in italijanskem prevodu tega romana prevajalca Arnolda Bressana. T. Onič predstavi angleški prevod Cankarjevih Podob iz sanj izpod peresa ameriškega Slovenca Antona Družine, ki je leta 1983 izšel pri Slovenskem ameriškem inštitutu, in s kontrastivno slogovno analizo črtice Gospod stotnik pokaže na prevodne premike, ki vplivajo tudi na makrostrukturo prevodnega besedila. U. Marinšek in T. Onič pišeta o adaptaciji Cankarjeve farse Pohujšanje $v$ dolini šentflorjanski $\mathrm{v}$ ameriškem prostoru in njeni uprizoritvi v San Diegu leta 2012 pod vodstvom slovenskega igralca Ivana Rupnika (Čeh Steger 2018: 13-14).

Tretji sklop CANKAR IN NJEGOVI LITERARNI SODOBNIKI obravnava Cankarja v odnosu do Josipa Murna, Janeza Trdine in Zofke Kveder. Tukaj so zbrane razprave: Denisa Poniža (Cankarjev odnos do Murnove lirike), Silvije Borovnik (Literarno prijateljstvo med Ivanom Cankarjem in Zofko Kveder) in Igorja Krambergerja (Posledice prevzetosti. Cankarjeva branja Trdine. 1. del). D. Poniž na podlagi ohranjenih virov natančno razišče Cankarjev odnos do Murnove poezije in ovrže mit o harmonični podobi štirih predstavnikov slovenske moderne, ki da so bili med seboj prijateljsko povezani in usklajeni tudi na estetski ravni. Ugotavlja namreč, da je bil Cankarjev odnos do Murnove poezije v času Zadruge oziroma Murnove smrti odklonilen in se je spremenil šele po pesnikovi prezgodnji smrti ter pod vplivom Prijateljevega eseja ob izidu 
Murnove pesniške zbirke Pesmi in romance (1903). S. Borovnik piše o prijateljstvu med Ivanom Cankarjem in Zofko Kveder na podlagi njune ohranjene korespondence, iz katere med drugim razbira, da sta drug drugega spodbujala pri literarnem ustvarjanju, Z. Kveder pa je Cankarjeva besedila tudi objavljala, prevajala in jih posredovala $\mathrm{v}$ hrvaški, češki in nemškim kulturni prostor. I. Kramberger izhaja iz Cankarjevih pohvalnih omemb Trdine v Cankarjevih literarnih delih, kritikah in pismih ter razmišlja o učinkih Cankarjeve prevzetosti nad Trdino. V objavljenem delu širše razprave je prikazano obdobje izhajanja Trdinovih Zbranih spisov pri Schwentnerju (Čeh Steger 2018: 14).

Četrti sklop RECEPCIJSKE, INTERPRETACIJSKE, MEDBESEDILNE IN MEDMEDialne RAZISKaVE CANKARJEVIH DEL vključuje razprave o recepciji, subverzivnosti, referencah, umetnosti, morali, medmedialnosti, estetiki in interpretaciji Cankarjevih del. V ta sklop so uvrščene razprave: Mirana Štuheca (Izidor Cankar in njegova recepcija Ivana Cankarja), Blanke Bošnjak (Subverzivnost Cankarjevega dela Hlapec Jernejin njegova pravica), Branislave Vičar (Reference na Cankarja v partizanski artikulaciji »kulturnega boja«), Krištofa Jacka Kozaka (Šentflorjanska tragedija ali o umetnosti in morali), Tomaža Toporišiča (Pohujšanje v odrskih utelešenjih 20. in 21. stoletja), Jerneja Kusterleta (Cankarjeva Erotika z vidika dekadenčne estetike), Anne Bodrove (Interpretacijski potencial avtobiografske črtice Ivana Cankarja Skodelica kave), Dragice Haramije in Janje Batič (Slikanice o Cankarju in Cankarjeva dela v slikanicah). M. Štuhec se je posvetil esejističnim uvodom k Cankarjevim Zbranim spisom (1925-1936), ki jih je napisal pisateljev bratranec Izidor
Cankar, tudi urednik te prve temeljne zbirke Cankarjevih del, in razgrnil pronicljivost urednikovih uvidov v večplastno problematiko Cankarjeve besedne umetnosti. B. Bošnjak predstavi nasprotujoče si odzive na Cankarjevega Hlapca Jerneja in njegovo pravico $\mathrm{v}$ izbranih delih slovenske literarne zgodovine in kritike. B. Vičar pokaže, kako se je Cankarjevo razumevanje kulture in »kulturnega boja« vgradilo v medbesedilne in meddiskurzivne strukture partizanskih besedil o kulturi in umetnosti. Kozak razbira v Cankarjevi farsi Pohujšanje $v$ dolini šentflorjanski nastavke, ki to besedilo približujejo tragediji. Posveti se etičnemu naboju doline Šentflorjancev kakor tudi njeni razdalji do tragičnega. T. Toporišič razgrne panoramski, mestoma tudi podrobnejši pregled na posamezna utelešenja Cankarjeve farse Pohujšanje v dolini šentflorjanski, ki kot eno najbolj subverzivnih besedil dramatike 20. stoletja ostaja aktualna in doživlja nove uprizoritve tudi v današnjem času. J. Kusterle poveže estetiko grdega s pojmom moderna in na ta način opazuje dekadenčno estetiko v Cankarjevi Erotiki. A. Bodrova ponudi različne interpretacije Cankarjeve Skodelice kave z vidika različnih metod in znanstvenih modelov ter opozori na neobremenjeno branje te črtice pri ruskem bralcu. D. Haramija in J. Batič se ukvarjata $\mathrm{z}$ medmedialnim branjem Cankarja in predstavita simbiozo likovnega ter besednega izraza v slikanicah o Cankarju kakor tudi v slikaniških variantah Cankarjevih besedil (Čeh Steger 2018: 14-15).

V poglavju JEZIKOSLOVNE RAZPRAVE CANKARJEVIH LITERARNIH DEL spoznavamo v posameznih Cankarjevih delih tipologijo zvez, medmetov, jezikovnostilistično analizo kakor tudi analizo jezikovnih posegov in govorno 
interpretacijo posameznih besedil. Gre za razprave: Irene Stramljič Breznik (Tipologija zvez s kakor v Cankarjevih črticah Moje življenje), Ines Voršič (»Pa kaj si storil ti, oj človek?" - Medmeti v Cankarjevih živalskih pripovedih), Mire Krajnc Ivič (Cankarjeva Nina kot primer neizražene ljubezni - jezikovnostilistični pogled), Natalije Ulčnik (Jezikovni posegi v različnih izdajah Cankarjeve komedije Za narodov blagor) in Nine Žavbi Milojević (Govorna interpretacija $v$ treh gledaliških uprizoritvah Cankarjevih Hlapcev).

I. Stramljič Breznik se je ukvarjala $\mathrm{z}$ jezikoslovno tipologijo besednih in stavčnih zvez s kakor v Cankarjevem Mojem življenju in pri tem upoštevala tudi literarnovedna in jezikovnostilna izhodišča. S pomočjo korpusne metode med drugim ugotavlja, da je Cankar ustaljene besedne zveze prenavljal z izvirno izbiro primerjalnih besed. I. Voršič se je posvetila medmetom v Cankarjevih živalskih črticah, o katerih ugotavlja, da podpirajo simboliko zvoka, ki vzbuja v človeku občutja strahu, groze, potrtosti ipd. M. Krajnc Ivič se je ukvarjala $\mathrm{z}$ jezikoslovnostilistično analizo Cankarjeve vinjete Nina in iz prepleta kohezivnosti ter koherentnosti izpeljala njen smisel. N. Ulčnik se je ukvarjala z jezikovno podobo Cankarjeve komedije Za narodov blagor v različnih izdajah, pri čemer so jo posebej zanimali jezikovni in drugi posegi $\mathrm{v}$ avtorjevem izvodu prve izdaje iz leta 1902, ki so nastali v kontekstu priprav za gledališko uprizoritev tega dela. N. Žavbi Milojević se je osredinila na govorno interpretacijo odrskega govora $\mathrm{v}$ treh časovno različnih gledaliških uprizoritvah Cankarjeve drame Hlapci in ugotovila večjo ustvarjalnost teh prvin v mlajših uprizoritvah (Čeh Steger 2018: 15-16).
Zadnje poglavje $\mathrm{v}$ monografiji CANKAR V ŠOLI prinaša zanimiv vpogled v preučevanje in poznavanje Ivana Cankarja $\mathrm{v}$ slovenskem šolskem prostoru. To so razprave: Milene Mileve Blažič (Cankar v osnovnošolskih učnih nacrtih), Simone Pulko (Ivan Cankar in njegova dela $v$ berilih za srednje šole in berilih za gimnazije), Tjaše Markežič (Z Ivanom Cankarjem na splošni matu$r i)$ in Melite Zemljak Jontes (Besedišče Cankarjeve črtice Bobi v normativnih slovarskih priročnikih slovenskega jezika in nacionalnem korpusu Gigafida). M. M. Blažič predstavi mesto Cankarja v osnovnošolskih učnih načrtih v kontekstu družbenopolitičnih sprememb. S. Pulko je pregledala zastopanost Cankarjevih del v šolskih programih in učbeniških gradivih za pouk slovenščine v gimnazijah od začetka osemdesetih let prejšnjega stoletja vse do današnjih dni in opazovala njihovo spreminjanje v kontekstu šolskih in družbeno-političnih sprememb. Na podlagi preglednega gradiva ugotavlja prisotnost Cankarja in njegovih del $\mathrm{v}$ vseh učnih načrtih kakor tudi spreminjanje izbora in količinske zastopanosti njegovih besedil. T. Markežič ugotavlja, da predpisuje predmetni izpitni katalog za slovenščino za ustni del mature poznavanje več Cankarjevih besedil, kar upošteva tudi učni načrt za gimnazijo. Prav tako navaja, da se Ivan Cankar uvršča med najpogosteje izbrane avtorje maturitetnega sklopa iz književnosti, ki je podlaga za razlagalni/interpretativni šolski esej. $\mathrm{M}$. Zemljak Jontes predstavi pregled pomenskih in kvalifikatorskih označitev besedišča v Cankarjevi črtici Bobi s pomočjo normativnih slovarjev in nacionalnega korpusa Gigafida ter ponudi računalniško podprto možnost analize Cankarjevega besedišča za potrebe mladega bralca (Čeh Steger 2018: 16). 
Znanstvena monografija Ivan Cankar v medkulturnem prostoru, ki je izšla ob stoti obletnici Cankarjeve smrti, je prava zakladnica informacij o največjem mojstru slovenske besede in velikem mislecu takratnega časa. Razprave v tej monografiji z različnih znanstvenih disciplin in zornih kotov na novo osvetljujejo Cankarjevo literarno ustvarjalnost in njegovo vpetost $\mathrm{v}$ slovenski ter evropski kulturni prostor. Slovenska literarna veda je s to monografijo postala bogatejša za nova meddisciplinarna, literarnozgodovinska, kulturološka, prevodoslovna, jezikoslovna in didaktična razmišljanja o Ivanu Cankarju in njegovem ustvarjalnem opusu.

Monografija Ivan Cankar $v$ medkulturnem prostoru priča, da so Cankarjeva literarna dela po več kot sto letih še zmeraj aktualna in sodobna ter nas nagovarjajo $\mathrm{k}$ medkulturnemu dialogu.

Informacijska doba, v kateri živimo, je, žal, velikokrat tudi doba nerazumevanja in netolerantnosti med posamezniki, narodi, kulturami in religijami, zato je izdaja monografije, ki raziskuje medkulturnost, zaradi njene povezovalne vloge zelo dobrodošla. Izid monografije Ivan Cankar v medkulturnem prostoru so finančno podprli Rektorski sklad Univerze v Mariboru, Filozofska fakulteta Univerze v Mariboru, Oddelek za slovanske jezike in književnosti Filozofske fakultete v Mariboru in podjetje Tamstan, d. o. o. Namenjena je strokovni javnosti, študentom in študentkam slovenistike, slavistike in primerjalne književnosti, v branje pa jo priporočam tudi vsem ljubiteljem slovenske književnosti, jezika in kulture.

\section{LITERATURA}

Jožica ČEH STEGER, 2018: Uvodna beseda. Ivan Cankar v medkulturnem prostoru. Ob stoti obletnici Cankarjeve smrti. Ur. Jožica Čeh Steger, Simona Pulko, Melita Zemljak Jontes. Maribor: Univerzitetna založba Univerze. (Mednarodna knjižna zbirka Zora, 126). $10-16$.

\section{Silva Beľsak}

Univerzitetna knjižnica Maribor, silva.belsak@um.si

\section{PROJEKT SLOVENŠC̆INA NA DLANI}

Na Univerzi v Mariboru od avgusta leta 2017 poteka projekt Slovenščina na dla$n i$, pri katerem sodelujejo Filozofska fakulteta (FF), Fakulteta za elektrotehniko, računalništvo in informatiko (FERI) ter Pedagoška fakulteta (PEF). Osnovni namen projekta je pripraviti učno e-okolje za slovenščino, ki se bo uporabljalo v osnovnih šolah od 6. razreda in v srednjih šolah, s prostim dostopom na spletu pa bo od leta 2021, ko se projekt zaključi, njegova raba omogočena tudi drugim uporabnikom; dostopno bo na računalnikih, tablicah in pametnih telefonih. Projekt sofinancirata Republika Slovenija (Ministrstvo za kulturo) in Evropska unija iz Evropskega socialnega sklada.

Učno e-okolje pripravlja skupina slovenistov, jezikoslovcev, jezikovnih tehnologov, programerjev, didaktikov, učiteljev iz prakse in drugih strokovnjakov, aktivno pa sodelujejo tudi učiteljice in učitelji z 14 vzgojno-izobraževalnih zavodov iz vzhodne in zahodne kohezijske regije: Gimnazija Franca Miklošiča Ljutomer, Gimnazija Ormož, Prva gimnazija Maribor, OŠ Pesnica pri Mariboru, Šolski center Rogaška Slatina, OŠ 
Primoža Trubarja Laško, OŠ Sava Kladnika Sevnica, Šolski center Postojna; Gimnazija Tolmin, OŠ Danila Lokarja Ajdovščina, OŠ Naklo, OŠ Draga Bajca Vipava, Zavod Sv. Frančiška - OE Gimnazija Želimlje, OŠ Vižmarje Brod. Obenem se povezujemo tudi s primarnimi uporabniki, torej z učenci in dijaki, ki s svojimi predlogi in idejami pomagajo pri zasnovi. Prepričani smo namreč, da lahko s skupnimi močmi pripravimo e-okolje, ki bo kvalitetno, uporabno in inovativno, s tehnološko-grafičnega vidika pa privlačno za mlade. Prav zato smo že v izhodišču načrtovali vključevanje interaktivnosti in tistih elementov oz. funkcionalnosti, ki so sicer značilne tudi za igričarstvo.

Zasnova e-okolja je vsebinsko široka in zajema 4 področja, ki smo jih poimenovali s slogani: 1) pravopis (Vejico stresem iz rokava), 2) slovnica (Slovnica $v$ malem prstu), 3) frazeologija (Več znaš, več veljaš) in 4) besedila (Iz malega zraste veliko). Vsako področje se podrobneje členi na podpodročja in izhajajoč iz učnih načrtov skuša celostno zajeti obravnavano tematiko, pri čemer se osredinja na vsebine, ki so se na osnovno- in srednješolski ravni izkazale kot bolj problematične. Okolje bo učencem in dijakom ter drugim uporabnikom ponujalo vaje in naloge, ki bodo temeljile na izhodiščnih korpusih, pripravljenih v projektu, omogočalo pa bo tudi brskanje po t. i. bazi znanja (Vsak zakaj ima svoj zato), v kateri bodo jezikoslovni pojmi teoretično pojasnjeni in praktično ponazorjeni ter bodo lahko služili kot pomoč pri reševanju vaj in nalog. Osnovni cilj e-okolja je izboljšanje jezikovnih in digitalnih kompetenc uporabnikov, pri čemer upoštevamo temeljna didaktična priporočila, npr. individualizacijo, diferenciacijo in formativno spremljanje.
V prvem letu izvajanja projekta (2017) smo izvedli pripravljalne dejavnosti, v okviru katerih smo vzpostavili projektno spletno stran (http://projekt. slo-na-dlani.si/sl/), oblikovali celostno grafično podobo (skupaj s podjetjem Biro Biro), vzpostavili spletni strežnik, intranet portal, Facebook in Twitter profil. Pri oblikovanju logotipa smo izhajali iz vsebine in namena e-okolja, skušali smo preplesti osnovne elemente, ki se povezujejo z njegovo zasnovo, tj. znanje (stilizacija knjige, na podlagi katere običajno poteka učenje), digitalizacija (prehod v elektronsko obliko, podoba knjige se zlije s podobo vezja), dostopnost (dlan/»na dlani«; prim. sliko 1). Za znak smo izbrali modro barvo, ki simbolizira znanje oz. modrost, pri tipografskem delu pa smo se poigrali z velikimi in malimi črkami. Pripravili smo tudi promocijsko gradivo in plakate.

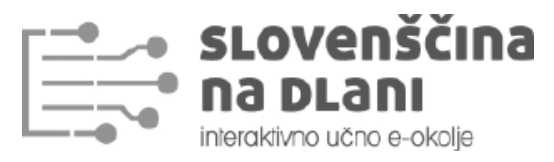

Slika 1: Logotip projekta Slovenščina na dlani

Začeli smo z osrednjimi dejavnostmi za pripravo e-okolja, pri čemer smo sprva naredili analizo obstoječih e-okolij oz. e-gradiv za slovenščino ter specificirali zahteve za naše učno okolje. Skladno z inovativnimi didaktičnimi pristopi smo razmišljali o osnovnih funkcionalnostih okolja in izdelali prototip, ki smo ga predstavili na prvem izobraževanju za učiteljice in učitelje. Zbrali smo njihove odzive in pobude ter jih smiselno upoštevali v naslednjih fazah zasnove.

V drugem projektnem letu (2018) smo nadaljevali s pripravo učnega e-okolja. Ukvarjali smo se zlasti z izdelavo korpusov, na podlagi katerih bodo 
nastajale vaje in naloge, ustvarili smo potrebne vmesnike, sklepali pogodbe $\mathrm{z}$ gradivodajalci in urejali avtorske pravice. Korpus za pravopisno-slovnični sklop smo poimenovali MAKS (MlAdinski Korpus beSedil), pisni in govorni korpus za področje besedil BERTA (BesEdila pRakTičnega sporazumevanjA), korpus za področje frazeologije pa FRIDA (Frazemi in pRegovorI na DlAni). Začeli smo tudi $z$ načrtovanjem vaj in nalog. Izvedli smo dve izobraževanji za učiteljice in učitelje slovenščine, za učence in dijake sodelujočih šol pa smo razpisali natečaj, na katerem smo zbirali fotografije na temo slovenščina na dla$n i$. Najboljše fotografije smo uporabili na promocijskem gradivu, kot so mape in zvezki (prim. sliko 2).

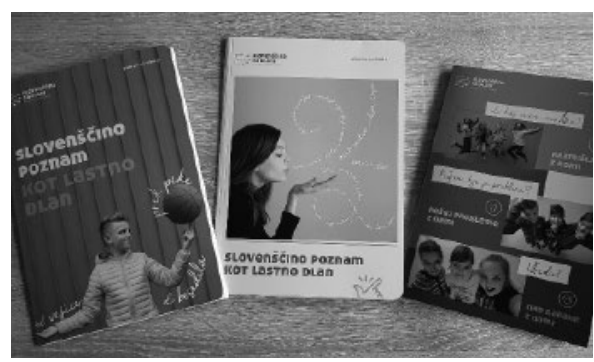

Slika 2: Promocijsko gradivo projekta Slovenščina na dlani

Pravkar poteka tretje projektno leto (2019), v katerem se je zaključila faza priprave korpusov, intenzivno pa se posvečamo pripravi vaj in nalog za posamezna vsebinska področja ter grafični podobi e-okolja. Izdelali smo seznam vaj s pripadajočimi tipologijami in navodili, definirali smo grafične elemente $\mathrm{k}$ vajam in nalogam, zasnovali smo grafično osnovo (GUI ,graphic user interface') ipd. Novembra 2019 bomo začeli s specifikacijami vključevanja razlag $\mathrm{v}$ naloge (za bazo znanja je predvidenih 200 razlag). Do konca leta bomo izdelali smernice in strategije na področju prožnih oblik učenja.

V okviru izobraževanj za učiteljice in učitelje vseskozi pripravljamo gradiva, jih seznanjamo z inovativnimi učnimi pristopi in metodami poučevanja ter s strokovnimi novostmi. Leta 2018 smo izdali strokovno monografijo Slovenščina na dlani 1 (http://press.um.si/index. php/ump/catalog/book/341), v kateri so zbrani zanimivi strokovni prispevki, obenem pa so predstavljeni prvi rezultati projektnega dela; tik pred izidom je tudi Slovenščina na dlani 2, v kateri strokovne prispevke objavljajo tudi sodelujoče učiteljice slovenščine.

Projektno delo v posameznih vsebinskih sklopih vodijo koordinatorice in koordinatorji: Darinka Verdonik s FERI skrbi za jezikovnotehnološki del, pripravo korpusa MAKS, področje pravopisa in slovnice; Mira Krajnc Ivič s FF koordinira slovenistično področje, skrbi za pripravo zbirke BERTA in za naloge, vezane na besedila; Simona Pulko s FF vodi didaktični del; Milan Ojsteršek s FERI koordinira področje programiranja; Polonca Šek Mertük s PEF skrbi za stike s šolami in za promocijski del; Natalija Ulčnik s FF vodi projekt in koordinira delo v frazeološki skupini.

Verjamemo, da bodo uporabniki novo učno e-okolje za slovenščino prepoznali kot kvalitetno, inovativno, koristno in privlačno, da bodo učiteljice in učitelji tudi z njegovo uporabo lahko popestrili in obogatili pouk slovenščine ter tako prispevali k povečanju motivacije za učenje in posledično $\mathrm{k}$ izboljšanju jezikovnih kompetenc, kar ponazarja tudi naš krovni slogan - Slovenščino poznam kot lastno dlan.

Natalija Ulčnik

Filozofska fakulteta Univerze v Mariboru, natalija.ulcnik@um.si 


\section{RAZSTAVA O IVANU CANKARJU ROMAL SEM PO ŠIROKI CESTI}

Ob stoletnici Cankarjeve smrti sta bila v Cankarjevem letu 2018 na Filozofski fakulteti Univerze v Mariboru izvedena dva pomembna dogodka: razstava o Ivanu Cankarju z naslovom Romal sem po široki cesti, otvoritev katere je bila $\mathrm{v}$ ponedeljek, 28. 5. 2018, in 2. mednarodna znanstvena konferenca Slavistični znanstveni premisleki z naslovom Cankarjev list $v$ cvetu bele krizanteme, ki je potekala 30. in 31. 5. $2018 \mathrm{v}$ organizaciji Oddelka za slovanske jezike in knjiŽevnosti v sodelovanju s Slavističnim društvom Maribor.

Razstava o Ivanu Cankarju z naslovom Romal sem po široki cesti je predstavljala skupni projekt Oddelka za slovanske jezike in književnosti Filozofske fakultete Univerze v Mariboru, Prve gimnazije Maribor in OŠ Pesnica. Otvoritev razstave je bila v ponedeljek, 28. 5. 2018, ob 11. uri v razstavišču, tj. v avli Filozofske fakultete v Mariboru. Razstava je bila od otvoritve do konca meseca avgusta 2018 na ogled na Filozofski fakulteti v Mariboru, nato se je meseca septembra selila na Prvo gimnazijo Maribor, nato pa še na OŠ Pesnica, kjer si jo je bilo mogoče ogledati do konca koledarskega leta.

V začetku meseca januarja leta 2018 smo se sestali predstavniki vseh treh institucij in porodila se je ideja, da $\mathrm{v}$ Cankarjevem letu pripravimo skupno razstavo. Tako je na Prvi gimnaziji Maribor vso pomoč in finančno podporo prijazno ponudil ravnatelj omenjene gimnazije, gospod Herman Pušnik, prav tako pa tudi ravnatelj OŠ Pesnica pri Mariboru, mag. Andi Brlič.

Pri strokovnem delu pri pripravi razstave sta s Prve gimnazije sodelovali profesorici Metka Kostanjevec in Maja Lutar, z OŠ Pesnica profesorice mag. Gordana Rodinger, Mihaela Fike in Jasna Bačani, z Oddelka za slovanske jezike in književnosti pa predstojnica Oddelka, prof. dr. Jožica Čeh Steger, prof. dr. Dragica Haramija, izr. prof. Blanka Bošnjak, doc. dr. Simona Pulko in izr. prof. dr. Melita Zemljak Jontes. Ob tem je treba poudariti, da smo v vsebinsko pripravo razstave vključili tudi študente in študentke prve ter druge stopnje, ki so sodelovali pri pripravi razstave, študentke 2. letnika enopredmetnega in dvopredmetnega magistrskega pedagoškega študijskega programa slovenistike pa so bile ob tem še tutorice dijakom in dijakinjam ter učencem in učenkam.

Profesorice iz osnovne šole so skupaj s študentkami ter $\mathrm{z}$ učenci in učenkami pripravile vsebinski del razstave, ki je prikazoval življenje in delo Ivana Cankarja (njegove življenjske postaje, in sicer od Vrhnike do Ljubljane, vse do Dunaja in nato do Rožnika in Ljubljane). Profesorici s Prve gimnazije sta v sodelovanju s študentkami ter z dijaki in dijakinjami pripravili del razstave, ki se je navezoval na gledališke uprizoritve Cankarjevih dram, na Oddelku za slovanske jezike in književnosti pa smo se ukvarjali s prevodi Cankarjevih del $\mathrm{v}$ tuje jezike. Seveda pri pripravi nismo mogli zajeti vseh del, pač pa je bil pri snovanju narejen izbor del in izbor jezikov s poudarkom na srednjeevropskih jezikih. Tako smo pregledali prevode $\mathrm{v}$ češčino, madžarščino, nemščino, poljščino, slovaščino, srbščino in hrvaščino. Pri tem so bili predstavljeni prvi časopisni/revijalni in knjižni prevodi, prevajalci in odlomki iz posameznih del. Izbor prevodov je zajemal deset Cankarjevih del: Erotika, Pohujšanje $v$ dolini šentflorjanski, $O$ človeku, $k i$ je izgubil prepričanje, Na klancu, Hiša 
Marije Pomočnice, Martin Kačur, Hlapec Jernej in njegova pravica, Skodelica kave, Moje življenje (5. poglavje) in Gospod stotnik. Med Cankarjevimi deli je najpogosteje in v največ jezikov prevedena novela Hlapec Jernej in njegova pravica, ki je bila vse od dvajsetih let prejšnjega stoletja temeljno delo za prepoznavanje Ivana Cankarja v evropskem prostoru. Na razstavi so bili predstavljeni tudi knjižni prevodi Ivana Cankarja v sodobno nemščino izpod peresa izvrstnega avstrijskega prevajalca in literarnega zgodovinarja Erwina Köstlerja.

Vsega dela ne bi bilo mogoče izpeljati brez sodelovanja in pomoči posameznikov oz. ustanov:

- Prva gimnazija Maribor z gospodom ravnateljem Hermanom Pušnikom ter s profesoricama Metko Kostanjevec in Majo Lutar;

- OŠ Pesnica z gospodom ravnateljem Andijem Brličem in s profesoricami mag. Gordano Rodinger, Mihaelo Fike in Jasno Bačani;

- Miklošičeva knjižnica FPNM z vodjo knjižnice Mojco Garantini in s Terezijo Balant, ki sta poskrbeli, da smo dobili težko dostopna gradiva;
- Univerzitetna knjižnica Maribor z gospo Gabrijelo Kolbič, ki nam je pomagala pri zbirki drobnih tiskov;

- gospod Bernard Šiško z GRAFITI STUDIO d.o.o.;

- učenci in učenke, dijaki in dijakinji ter študenti in študentke, ki so ob vsem rednem šolskem oz. študijskem delu skupaj z nami stopili na široko cesto in so romali po njej.

Od otvoritve razstave so na vseh institucijah potekali vodeni ogledi. Prvi ogled je bil na dan otvoritve, tj. 28. 5. 2018, nato 18. 6. 2018 za vse dijake in dijakinje Konservatorija za glasbo in balet Maribor (Umetniška gimnazija) in 28. 8. 2018 za udeležence in udeleženke poletnih delavnic Mini univerze Filozofske fakultete Univerze v Mariboru. Vodeni ogledi za šole so potekali tudi na Prvi gimnaziji v Mariboru in na Osnovni šoli Pesnica.

Jožica Čeh Steger, Simona Pulko, Melita Zemljak Jontes

Filozofska fakulteta Univerze v Mariboru, jozica.ceh@um.si,simona.pulko@um.si, melita.zemljak@um.si 


\section{Navodila avtorjem}

Slavia Centralis (SCN) je revija, ki objavlja jezikoslovne, literarnoteoretične in literarnozgodovinske izvirne znanstvene prispevke s področja slavistike, odprta pa je tudi za take primerjalne interdisciplinarne raziskave. Revija objavlja prispevke v slovenščini, lahko tudi v drugih slovanskih jezikih, madžarščini, nemščini ali angleščini.

\section{Recenzijski postopek}

Vsak prispevek za SCN pregledata in ocenita dva neodvisna recenzenta ter ga predlagata za objavo.

Glavni urednik o tem pisno obvesti avtorja in mu posreduje morebitne pripombe, ki jih je potrebno upoštevati, da bo članek objavljiv; končno uredniško besedo ima glavni urednik. Zavrnjenih rokopisov ne vračamo - glavni urednik o tem pisno obvesti avtorja.

Uredniki lahko prispevke lektorirajo in jih (nevsebinsko) popravijo brez soglasja avtorjev.

Članki morajo vsebinsko in po tehnični pripravi besedila ustrezati naslednjim standardom:

- gre za še neobjavljene prispevke;

- oddati jih je potrebno v (1) elektronski obliki, združljivi z urejevalniki za okensko okolje, tehnični urednici na naslov: natalija.ulcnik@um.si in (2) rokopisu v dveh natisnjenih izvodih na naslov: Oddelek za slovanske jezike in književnosti - Slavia Centralis, Filozofska fakulteta, Univerza v Mariboru, Koroška cesta 160, SI - 2000 Maribor ali (3) po e-pošti v obliki pdf na naslov tehnične urednice.

- razprave naj obsegajo 25.000 do 35.000 znakov, ocene 14.000 do 18.000 znakov, poročila 6.000 do 8.000 znakov;

- sinopsis v slovenskem in angleškem jeziku naj obsega 8 do 10 vrstic; dodanih naj ima 4 do 6 ključnih besed;

- povzetek naj obsega 25 do 30 vrstic - razprave, ki so napisane v slovenščini, imajo povzetek v angleščini, neslovensko napisane razprave pa v slovenščini in angleščini;

- pisava je Times New Roman, velikost črk 12 pik (izvleček in povzetek 10 pik), razmik med vrsticami naj bo 1,5 ;

- format papirja naj bo A4, robovi naj bodo $25 \mathrm{~mm}$ zgoraj, spodaj, levo in desno (severnoameriški format papirja $\mathrm{z}$ robovi širine enega inča);

- opombe naj bodo sprotne, vezaji, pomišljaji in narekovaji naj bodo v skladu s slovenskim pravopisom (oz. pravopisnimi normami jezikov, v katerih so razprave napisane);

- literatura naj bo navedena $\mathrm{v}$ besedilu in opombah $\mathrm{v}$ krajši obliki v oklepaju (Jesenšek 2005: 279), v daljši obliki pa na koncu razprave v seznamu literature in navedenk;

- če je v seznamu literature več del enega avtorja, naj pri vseh neprvih navedbah ime in priimek avtorja nadomeščata dva pomišljaja;

- če je v seznamu literature pri enem avtorju več navedenk istega leta, jih ločimo z malimi tiskanimi črkami stično ob letnici (2007, 2007a, 2007b);

- v seznamu literature navajamo:

- monografija:

Marko JESENŠEK, 2005: The Slovene Language in the Alpine and Pannonian Language Area. Kraków: Towarzystwo Autorów i Wydawców Prac Naukowych Universitas.

Mihaela KOLETNIK, 2008: Panonsko lončarsko in kmetijsko izrazje ter druge dialektološke razprave. Maribor: Mednarodna založba Oddelka za slovanske jezike in književnosti, Filozofska fakulteta. (Mednarodna knjižna zbirka Zora, 60). 


\section{- članek v reviji:}

Martina OROŽEN, 1993: Kontinuiteta starocerkvenoslovanskega besedišča v slovenskem jeziku. Slavistična revija 41/1, 143-160.

- članek v monografiji ali zborniku:

Zinka ZORKO, 2004: Izbrano besedje v narečjih severovzhodne Slovenije. Besedoslovne lastnosti slovenskega knjižnega jezika in narečij. Ur. Marko Jesenšek. Maribor: Slavistično društvo Maribor. (Zora, 28). 170-228.

Miran ŠTUHEC, 2003: Esejistika narodnih tem in njen pomen danes. Perspektive slovenistike ob vključevanju v Evropsko zvezo. Ur. Marko Jesenšek. Ljubljana: Slavistično društvo Slovenije. (Zbornik Slavističnega društva Slovenije, 14). 63-80.

- slikovno gradivo, razpredelnice ipd. (izdelano v MS Excel) naj bo priloženo na posebnih listih, $v$ tekočem besedilu pa naj bo označeno, kam sodi (podnapisi slik naj bodo $\mathrm{v}$ tipkopisu); za oštevilčenje se uporabljajo samo arabske številke;

- mednaslovi so v polkrepkem tisku;

- ponazarjalni zgledi in daljši navedki so brez narekovajev, stopnja 10 pik, odstavčno ločeni;

- natančne informacije glede označevanja nestandardnih znamenj (označeni naj bodo z rdečo barvo in dodatno izrisani na robu besedila), ležečega in polkrepkega tiska dobi avtor pri tehnični urednici;

- naslovna stran tipkopisa naj vsebuje: naslov članka, ime in priimek avtorja, naslov ustanove, na kateri dela, njegov elektronski naslov in naslov, na katerega bodo poslane korekture;

- korekture je potrebno opraviti v petih dneh. 


\section{Guidelines for contributors}

The journal Slavia Centralis (SCN) publishes articles presenting original research in Slavic linguistics and literary scholarship; it is also open to interdisciplinary approaches. Papers may be published in Slovene and other Slavic languages, as well as Hungarian, German, and English.

\section{Refereeing process}

$\mathrm{SCN}$ is a double-blind refereed journal. Two independent reviewers referee each paper. If an article is accepted, the editor-in-chief informs the author in writing and conveys the requested emendations, if any, that must be made before the article is accepted for publication. Rejected manuscripts are not returned; however, the editor-in-chief informs the author in writing. Final editorial authority rests with the editor-in-chief. The editors reserve the right to make formal (non-substantive) changes to the paper without consulting the author.

The content and format of the articles must conform to the following criteria:

- The work must not have been published previously.

- Each article must be submitted in (1) electronic Windows-compatible format to the technical editor natalija.ulcnik@um.si and either (2) two printed copies on paper to Oddelek za slovanske jezike in književnosti - Slavia Centralis / Filozofska fakulteta, Univerza v Mariboru, Koroška cesta 160 / SI - 2000 Maribor or (3) by e-mail in PDF format to the technical editor.

- Articles should contain between 25,000 and 35,000 characters; reviews 14,000 to 18,000 characters, and reports from 6,000 to 8,000 characters.

- The English abstract should be 8 to 10 lines; it should include 4 to 6 keywords.

- The summary should contain 25 to 30 lines; articles written in Slovene will have an English summary; articles not in Slovene will have Slovene and English summaries.

- Articles should be written in 12-point Times New Roman font; the abstract should be in 10-point, line spacing should be 1.5 .

- Paper format is A 4, margins should be $25 \mathrm{~mm}$ on all sides or on North America lettersize paper with one-inch margins on all sides.

- Footnotes should be at the bottom of the page. Hyphens, $n$-dashes and m-dashes should be used as appropriate, according to the norms in the language in which the article is written.

- Bibliographical citations should be noted in the literature using in-text citations in parentheses, e. g., (Jesenšek 2005: 279), followed by full citations in a listing of references at the end of the article.

- If the bibliographical item has multiple works by the same author, subsequent citations of the author must replace the author's name with two m-dashes.

- If several items by the same author have the same year, subsequent articles should have a lower-case letter after the year, e. g., (2007, 2007a, 2007b).

- Citation format:

- Monograph:

Marko JESENŠEK, 2005: The Slovene Language in the Alpine and Pannonian Language Area. Kraków: Towarzystwo Autorów i Wydawców Prac Naukowych Universitas.

Mihaela KOLETNIK, 2008: Panonsko lončarsko in kmetijsko izrazje ter druge dialektološke razprave. Maribor: Mednarodna založba Oddelka za slovanske jezike in književnosti, Filozofska fakulteta. (Mednarodna knjižna zbirka Zora, 60). 
- Journal article:

Martina OROŽEN, 1993: Kontinuiteta starocerkvenoslovanskega besedišča v slovenskem jeziku. Slavistična revija 41/1, 143-160.

- Article in a book or anthology:

Zinka ZORKO, 2004: Izbrano besedje v narečjih severovzhodne Slovenije. Besedoslovne lastnosti slovenskega knjižnega jezika in narečij. Ed. Marko Jesenšek. Maribor: Slavistično društvo Maribor. (Zora, 28). 170-228.

Miran ŠTUHEC, 2003: Esejistika narodnih tem in njen pomen danes. Perspektive slovenistike ob vključevanju v Evropsko zvezo. Ed. Marko Jesenšek. Ljubljana: Slavistično društvo Slovenije. (Zbornik Slavističnega društva Slovenije, 14). 63-80.

- Graphics, tables, etc. (produced in MS Excel) should be given on separate sheets and their placement should be indicated in the text (captions of pictures should be in the manuscript); use only Arabic numerals for numbering.

- Subtitles should be in boldface.

- Examples and longer quotations should be without quotations, 10 point, with paragraph breaks.

- Precise descriptions of non-standard signs (marked in red and noted in the margin), italics, and boldface, will be given to the author by the technical editor.

- The title page should contain: the title of the article, the name and surname of the author, the title of his or her place of employment, the author's e-mail (for the receipt of proofs).

- Proofs must be corrected and returned in five days. 

